Portland State University

PDXScholar

$1-1-1977$

\title{
An investigation into the elasticity of demand for motor gasoline
}

Samy Fouad El-Iskandarany

Portland State University

Follow this and additional works at: https://pdxscholar.library.pdx.edu/open_access_etds Let us know how access to this document benefits you.

\section{Recommended Citation}

El-Iskandarany, Samy Fouad, "An investigation into the elasticity of demand for motor gasoline" (1977). Dissertations and Theses. Paper 599.

https://doi.org/10.15760/etd.599

This Dissertation is brought to you for free and open access. It has been accepted for inclusion in Dissertations and Theses by an authorized administrator of PDXScholar. Please contact us if we can make this document more accessible: pdxscholar@pdx.edu. 


\title{
AN INVESTIGATION INTO THE ELASTICITY \\ OF DEMAND FOR MOTOR GASOLINE
}

\author{
by \\ SAMY FOUAD EL-ISKANDARANY
}

\begin{abstract}
A thesis submitted in partial fulfillment of the requirements for the degree of

DOCTOR OF PHILOSOPHY

in

SYSTEMS SCIENCE
\end{abstract}

\section{Portland State University \\ 1977}

(C) 1977 Samy Fouad El-Iskandarany 
TO THE OFFICE OF GRADUATE STUDIES AND RESEARCH:

The members of the Committee approve the thesis of Samy Fouad El-Iskandarany presented December 9, 1977.
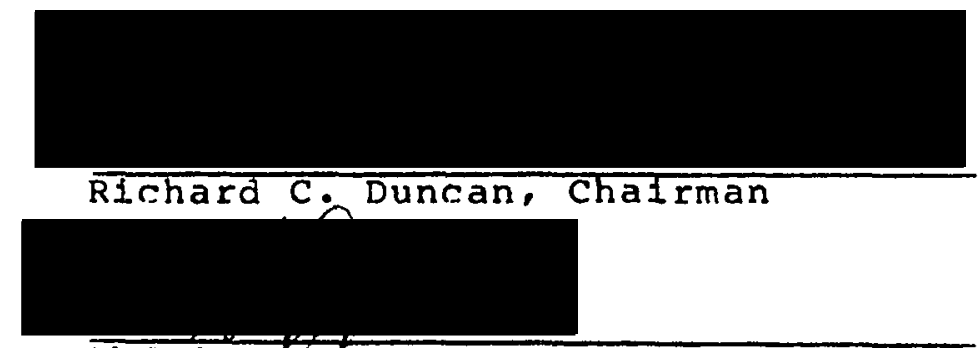

$$
\text { Abdu1 Qq্்ym }
$$
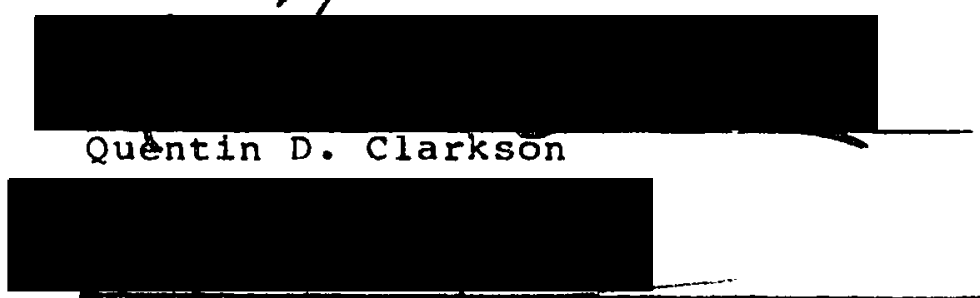

Vijay $k-6 a r g$

APPROVED :

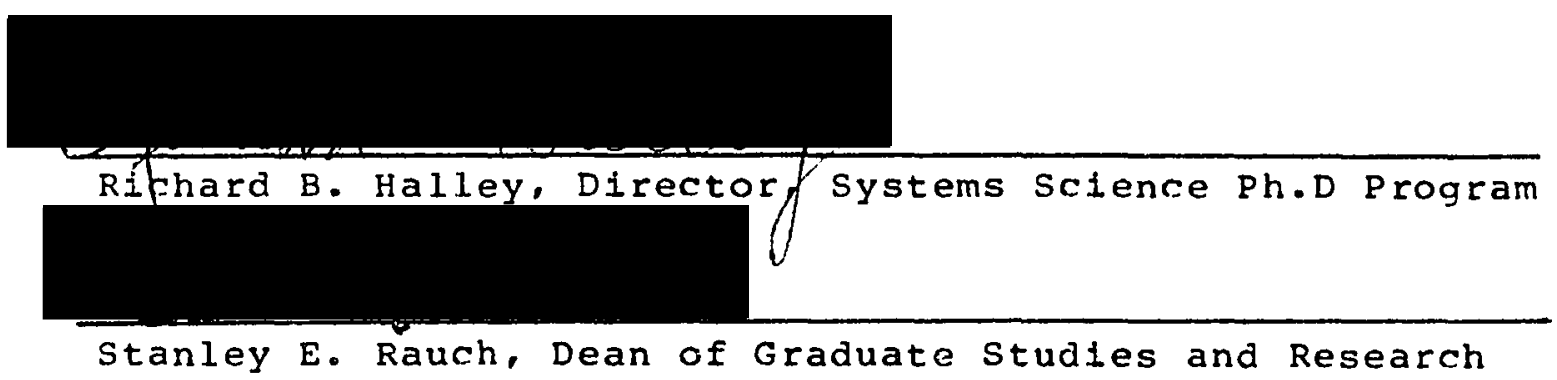


AN ABSTRACT OF THE THESIS OF Samy Fouad El-Iskandarany for the Doctor of Philosophy of systems Science presented December 9, 1977.

Title: An Investigation into the Elasticity of Demand for Motor Gasoline.

APPROVED BY MEMBERS OF THE THESIS COMMITTEE:
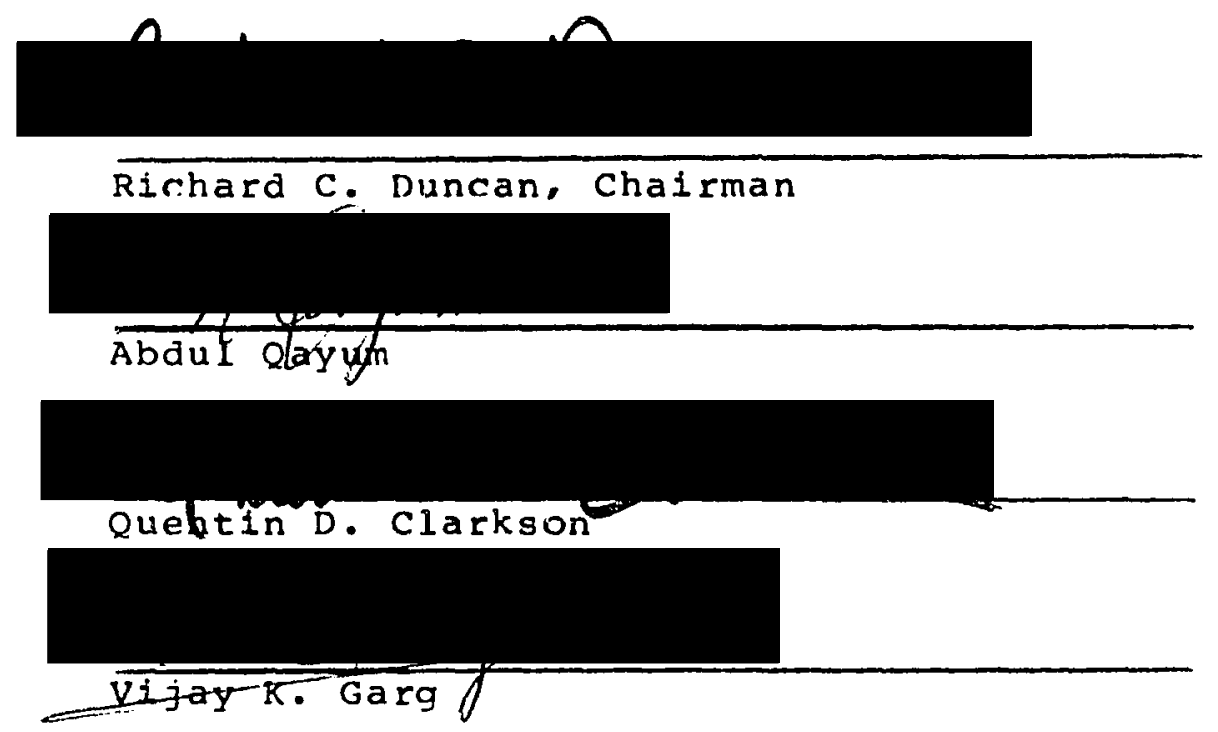

This thesis investigates the existence and determinants of the elasticity of demand for motor gasoline.

The research can be divided into four main stages. In the first stage, time series data of fifteen member countries of the Organization for Economic Cooperation and Development (OECD) are analyzed.

The ratio of gasoline price per galion to the per capita GNP is introduced in this research to explain the variability in 
the size of the price elasticities of demand over the various countries. The ratio is called the "Price Factor" and designated as P.F. The introduction of P.F. established the basis for meaningful inter-country comparisons of elasticity behavior. Three elasticity functions of P.F. are estimated via time series analysis.

In addition, time series analysis revealed a functional dependence of demand for motor gasoline on the per capita GNP lagged by one year.

In the second part of the thesis, the annual data of the various countries are examined cross sectionally. Based on the cross sectional analysis, demand is estimated as a function of P.F.

The third stage of the thesis is devoted to the validation of the research. Both the time series and the cross section findings are utilized for the retrogressive forecasting of demand levels in three countries of the OECD that were not. included in the analysis of the first two stages.

The vaildation section is concluded by choosing one of the elasticity functions estimated via time series analysis as the most accurate forecasting model. The forecasts provided by that specific function were quite satisfactory.

President Carter's energy program is examined in the fourth stage of the thesis using the function chosen in stage three. A temporal price profile is generated until the year 1990. This profile would achieve the President's goals for national consumption of motor gasoline. 
It is found that a 228 annual increase of gasoline price, to be introduced starting the year 1979 would achleve the goal of a 108 reduction in demand by the year 1985. Such a price profile suggests much higher taxation than proposed in the President's energy program. 
TO MY WIFE PERIHAN 


\section{ACKNOWLEDGMENT}

I would like to thank Professors Richard C. Duncan, AbduI Qayum, Quentin D. Clarkson and Vijay K. Garg for serving on my committee.

Special appreciation goes to Mr. Thomas Gerity, at the Portland State UnIversity Library for his enthusiastic help in locating hard to get references.

The staff of the computer center deserves my special acknowledgment for their friendiy cooperation. In particuiar, I like to mention Fred Dayton, David Hawkins, David Dinnuci and John MgLoughlin. My thanks also go to Mrs. Marie Brown in the office of Graduate Studies. No words will suffice to express my deep gratitude to my dear wife for her sincere and inteligent help, relentless efforts and her kind insplring support. 
TABLE OF CONTENTS

PAGE

ACKNOWLEDGMENT $\ldots \ldots \ldots \ldots \ldots \ldots \ldots \ldots \ldots \ldots \ldots \ldots \ldots$ iv

LIST OF TABLES $\ldots \ldots \ldots \ldots \ldots \ldots \ldots \ldots \ldots \ldots \ldots \ldots \ldots \ldots \ldots$

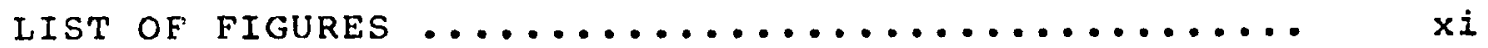

CHAPTER

I BACKGROUND...................... 1

Introduction................ 1

Research Objective............. 2

Theoretical Considerations....... 2

Significance of the

Transportation sector

On the Economic Theory of

Consumer Behavior

The Concept of Elasticity

Determinants of the Price

Elasticity of Demand

The Income elasticity of

Demand

Cross Elasticities of Demand

Theoretical Considerations

Pertaining to this Work

I I EXPERIMENTAL DESIGN AND METHODOLOGY....

The Intensity of Demand........ 17

Model variables................ 17

The Hypothesized Models......... 18

Elasticities of Demand.......... 19

Data Description and Analysis.... 21

Analysis Technique: Stepwise

Regression.............. 45 
I I EXPERIMENTAL DESIGN AND METHODOLOGY (cont'd)

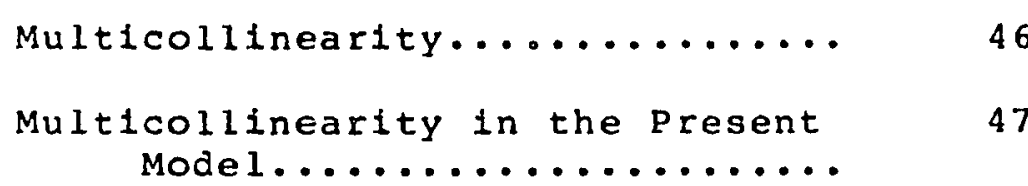

Research Methodology......... 51

II TIME SERIES ANALYSis.............

Model I.I: Model I with Lagged Variables Removed

Model I.2: Model I w1th $N(t)$ Removed

Model I.3: Model I with Current Varlables Removed

Model I.4: Model I.3 with $N(t)$ Added and $D(t-1)$ Removed

Model I.5: Model I.3 with $D(t-I)$ Removed

The $P(t)$ Elasticity of Demand....

Results of Model I

Results of Model I.I

Results of Model I.2

The $P(t-1)$ Elasticity of Demand..

Results of Model I
Results of Model I. 3
Results of Model I. 4
Results of Model I.I

The $G(t-1)$ Elast1c1ty of Demand... 124

Results of Model I
Results of Model I. 3
Results of Model I. 4
Results of Model I.5


IV CROSS SECTION ANALYSIS, MODEL VALIDATION AND CONCLUSIONS OF THE REGRESSION

ANALYSIS (cont'd)

Forecasts Based on Time

Series Results

Forecasts Based on the

Cross Section Results

Summary of the Regression Analysis

$\checkmark$ POLICY IMPLICATIONS OF THE RESEARCH

FINDINGS ................ 157

The Exploratory Run........... 157

Base Run

High Price Growth Rate

Expanding Economy

President Carter's Energy Program;

The Transportation Sector... 171

VI SUMMARY, CONCLUSIONS AND RECOMMENDATIONS 175

summary................ 175

Conclusions................ 178

Recommendations for Future

Research.............. 179

REFERENCES........................... 182 


\section{LIST OF TABLES}

TABLE

PAGE

II.1 Time Series Data for 15 OECD Countries......

II.2 Consumer Price Indices for varlous countries.

II.3 Principal Component Analysis for Austria....

I I I . Regression Coefficients for Model I........

I I .

Regresston Coefficients for Model II........

I I I.

Regression Coeffictents for Model III.......

III.4 Regression Coefficients for Model IV.......

III.5 Regression Coefflcients for Model I.1......

III.6 Regression Coefficlents for Model I.2......

III.7 Regression Coefficients for Model I.3....... 70

III.8 Regression Coefficients for Model I.4...... 72

III.9 Regression Coefficients for Model I.5...... 74

III.10 Various Elasticities of Demand: Model I....

IIII Average Elasticities for Different Ranges of P.F.: Model I...................

III.12 Curve Fit Results of $E(D(t), P(t))$ vs.

$$
\text { P.F.: Model I.................... } 84
$$

III.13 Various Elasticities of Demand: Model I.1... 86

III.14 Average Elasticities for Different Ranges

of P.F.: Model I.1................. 91

III.15 Curve Fit Results of $E(D(t), P(t))$ vs.

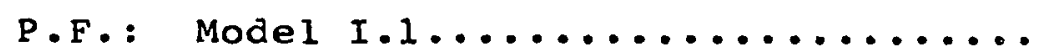


TABLE

III.16 Various Elasticities of Demand: Model I.2....

III.17 Average Elasticities for Different Ranges

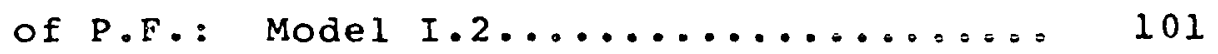

III.18 Curve Fit Results of $E(D(t), P(t))$ vs.

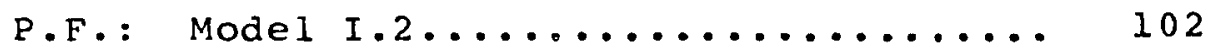

III.19 Varlous Elasticities of Demand: Model I.3... 104

III.20 Average Elasticities for Different Ranges

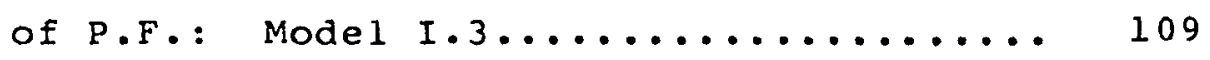

III.21 Various Elasticities of Demand: ModeI I.4... 110

III.22 Average Elasticities for Different Ranges

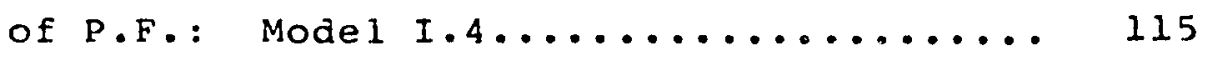

III.23 Various Elasticities of Demand: Model I.5... 117

III.24 Average Elasticitles for Different Ranges

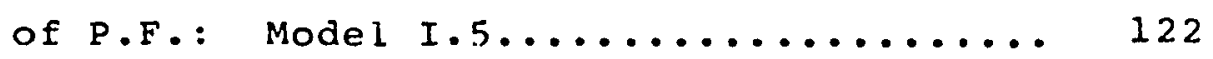

IV.1 Curve F1t of $D(t)$ vs. P(t) for $1970 \ldots \ldots 129$

IV.2 Curve F1t of $D(t)$ vs. $P(t)$ for $1975 \ldots \ldots . \ldots 1$

IV.3 Curve Fit of $D(t)$ vs. P.F. for $1970 \ldots \ldots 136$

IV.4 Curve Fit of DC(t) vs. P.F. for $1965 \ldots \ldots 138$

IV.5 Curve Fit of DC(t) vs. P.F. for $1976 \ldots \ldots$

IV.6 Curve Fit of DC(t) vs. P.F. for 1975........142

IV.7 Cross Sectional Demand Estimates: Various

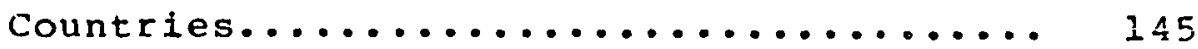

IV.8 Time Series Forecasts for France........... 147

IV.9 Time Series Forecasts for Ireland.......... 149

IV.10 Time Series Forecasts for Japan............ 


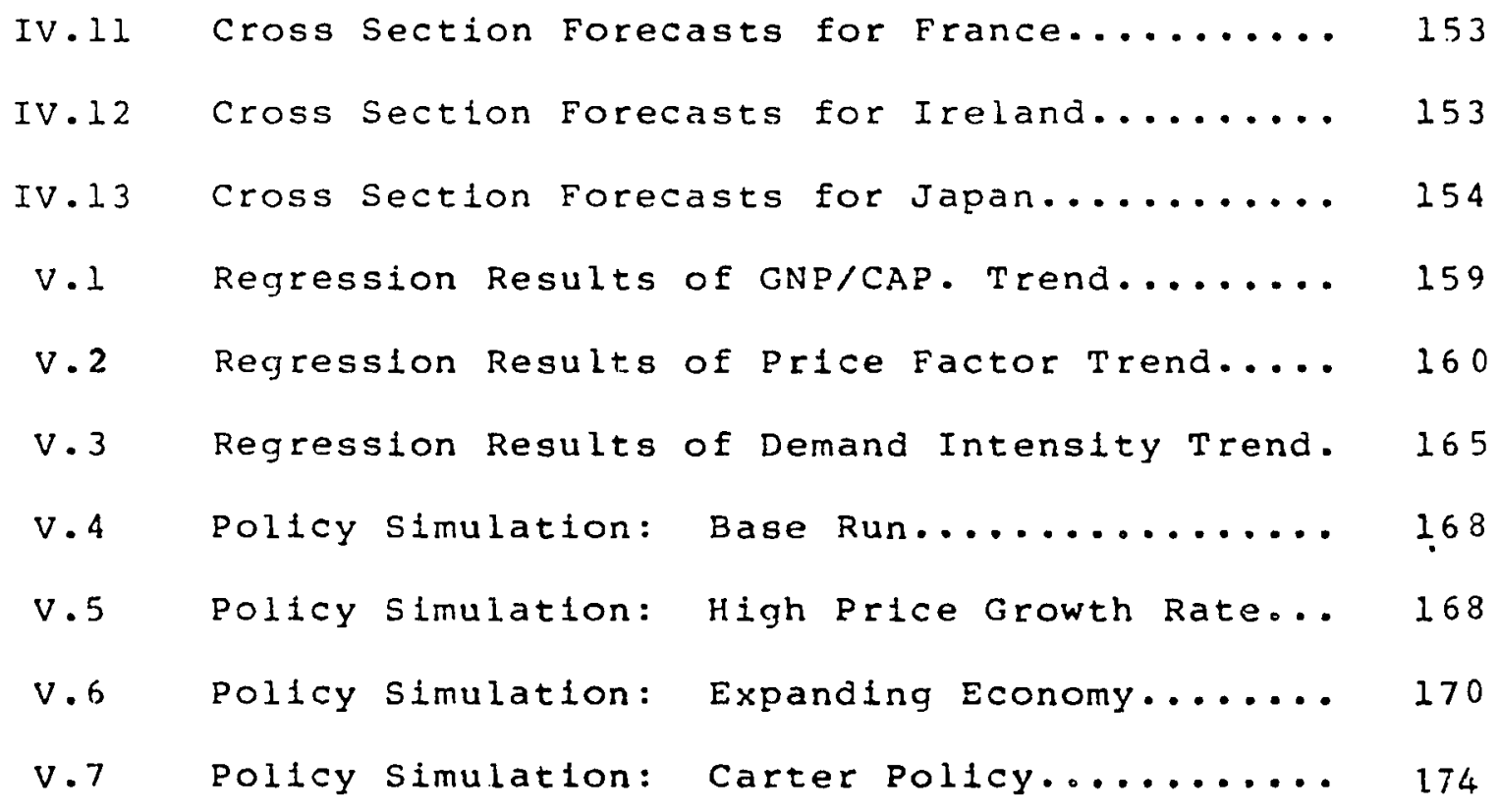




\section{LIST OF FIGURES}

FIGURE

PAGE

I.1 Various Demand Configurations............. 8

I.2 Enge $1^{\prime}$ s Curves...................... 10

I.3 Suggested Effect of Price Factor.......... 16

II.1 Time Plots: Various Countries............ 29

III.I Plots of the Three Estimated Elasticity

Functions........................ 100

IV.1 Scatter Diagram of D vs. P for $1970 \ldots \ldots \ldots 128$

IV. 2 Best Fit of $D$ vs. $P(t)$ for $1970 \ldots \ldots \ldots \ldots \ldots$

IV.3 Best Fit of $D$ vs. $P(t)$ for $1975 \ldots \ldots \ldots \ldots \ldots \ldots 132$

IV.4 Scatter Diagram of D Vs. P.F. for $1975 \ldots \ldots .134$

IV.5 Best Fit of D vs. P.F. for $1970 \ldots \ldots \ldots \ldots \ldots \ldots 135$

IV.6 Scatter Dlagram of DC vs. P.F. for $1965 \ldots \ldots .137$

IV.7 Best Fit of DC vs. P.F. for $1965 \ldots \ldots \ldots \ldots \ldots 139$

IV.8 Best Fit of DC vs. P.F. for $1970 \ldots \ldots \ldots \ldots \ldots 141$

IV.9 Best F1t of DC vs. P.F. for $1975 \ldots \ldots \ldots \ldots \ldots 143$

V.I Historical Trend of Real GNP/CAP......... 158

V.2 Historical Trend of the Price Factor....... 161

V.3 Historical Change in Gasoline Prices....... 163

V.4 Historical Trend of Demand Intensity....... 166 
CHAPTER I

\section{BACK GROUND}

\section{INT RO DUCT ION}

The recently realized seriousness and severity of the shortages in fossil energy resources prompted the need for detalled and thorough studies. The current study explores the demand determinants for one foss1l fuel by-product, viz., motor gasoline.

Traditional models treat demand for petroleum products as basically Inelastic to price (Adelman, 1975, p. 271). The levels of demand were usually related to those of GNP and population (Rothkopf, 1974, p. 107), or simply assumed to be an increasing function of time (Kalymon, 1975, p. 346).

Prior to the oll embargo of 1973, prices of crude oll were quite low relative to those of other commodities and had been decreasing in real terms. Under such conditions, the assumption of short run price inelast $\pm c$ demand was justifiable.

To maintain such an assumption for the post embargo era after the price of crude ofl has more than quadrupled is not warranted. It seems reasonable to propose that the price elasticlty question should be reexamined. 
Robinson (1975, pp. 37-40) states that

Forecasts of energy demand which take little or no account of price effects are likely to be misleading. What is needed is some econometric evidence on the likely response of aggregate energy demand to higher prices, but unfortunately there is nothing available; even for individual fuels there is little evidence on price elasticities.

Robinson emphasizes the difficulty of the task due to the structural change of post embargo vis a vis preembargo eras, and contends that the basis for reliable estimates may not exist. He further states:

The best that can be done at present is to put forward some statistics which give an indication of potential for price responsiveness in the energy market, though we cannot be sure what the response will actually be.

\section{RESEARCH OBJECTIVE}

It is the objective of this research to explore and analyze the factors influencing the demand for motor gasoline in transportation, estimate demand elasticities with respect to the different factors, and simulate the consumers behavior under alternative situations and pricing policies.

Time series and cross section data from fifteen countries of the Organization for Economic Cooperation and Development (OECD): an offspring of the European Economic Community (EEC) known as the European Common Market; are analyzed in this research. 
The following considerations pertain to the choice of the research topic and the underlying economic theory.

\section{Significance of The Transportation sector}

The transportation sector has been chosen for analysis for the following three reasons:

1. The amount of energy consumed in transportation is quite substantial. Leach (1973, p. 1) estimates that the 1973 world fleet of about $200 \mathrm{million}$ cars used up some 128 of world crude oil production, and that the percentage amounted to 508 for the U.S. compared to 178 for Europe. In 1969 the Net Energy Input (NEI) to the transportation sector in the U.S. reached 27.98 thus placing transportation "... above the whole domestic and commercial sectors and only a little below industry as a consumer of dwindling fossil fuel resources". Leach states that

Unless the higher estimates of ultimate world reserves for oil prove to be correct, the fuel demands of road transport are likely to provoke a severe oil shortage by the end of the century.

2. The primary input to a vehicle is fossil fuel, whereas the energy intake by a factory accounts only for a part (usually small) of the total input, and is usually rigidly determined. In the 
intensive studies of energy use in manufacturing industries included in the report of the Energy Policy Project of the Ford Foundation (1974, p. 568 ), the aluminum firms were interviewed and asked a series of questions relating to energy prices and possible industry responsiveness to higher prices. According to the report:

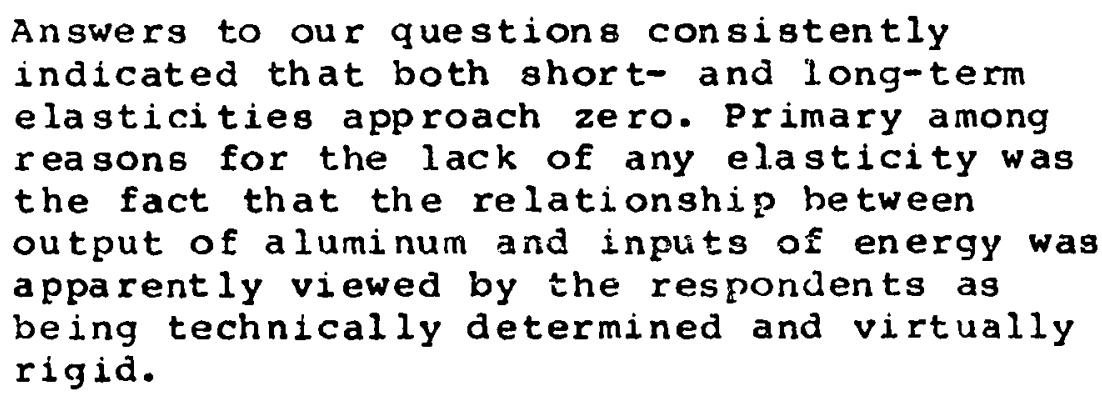

Table 1.3 on page 21 of the same report forecasts the gross energy intake by all manufacturing industries to be around 47,000 BTUms in 1980 for every fixed 1967 dollar of value added. Knowing that the heat equivalent of one BBL of crude is $5,618,570$ BTU-s, it can be seen that the above energy intake amounts to less than 18 of one BBL per 1967 dollar added.

For a price of about 10 dollars per BBL in 1975 and assuming 108 annual price increase, the 1980 energy intake by all manufacturing industries would amount to 0.22 dollars for every dollar of value added in 1967 fixed prices.

3. It is apparent that transportation, specially in 
the oEcn countries considered in this study, is highly decentralized and is likely to remain for at least the next 10 to 15 years. Therefore consumption decisions, hence demand, rest on individuals. This makes it amenable to the economic theory of consumer behavior.

\section{Qn The Economic Theory of Consumer Behavior}

The basic economic theory of consumer behavior postulates that the quantity demanded of a certain commodity is determined by maximizing the consumers utility function, which is a function of prices, quantities, tastes, preferences,...etc., subject to the consumers budget constraint. The resulting system of equations specifies a set of relations which the slopes of the demand function must satisfy.

The problem with strictly following the theory lies in estimating the utility function. Models which exactly satisfy the theory start by assuming a form for the utility function. Other models which approximately satisfy the theory start by assuming the demand function and attempt to impose the above described constraints on it. An excellent exposition of the basic theory is contained in Goldberger $(1967)$.

Bridge (1971) gives an excellent survey of econometric studies of demand functions which shows that demand ends up being a function of commodity prices and consumers income. 
In the dynamic case, lagged values of the same variables appear in the equation.

These findings were utilized in hypothesizing the models in the current work.

The concept of Elasticity

IF a variable $Y$ is a function of several explanatory variables $x(1), x(2), \ldots \times(n)$ such that

$Y=f(x(1), X(2), \ldots . X(n))$

then the elasticity of $Y$ with respect to $X(i)$ (also called

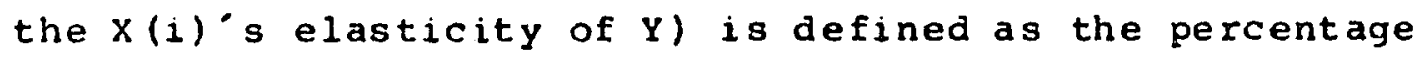
change in $Y$ resulting from a 18 change in $X(i)$ (Ferguson, 1975. Ch. III). In mathematical terms:

$E(Y, X(i))=(d Y / Y) /(d X(i) / X(i))$

Formula 2.2 can equivelantely be written as

$E(Y, X(i))=d \ln \cdot(Y) / d \ln \cdot(X(1))$

The size of $E$ is a measure of the responsiveness of $Y$ to changes in $x(i)$.

Price elasticity of demand $E(D, P)$ is accepted to be negative for a "Normal Good". This means that an increase in the price of a normal good to which substitutes exist and which is not a complement to an "Abnormal" good, will lead to a decrease in the quantity demanded.

Considering the absolute value of $E(D, P)$, we can 
distinguish between 5 possible cases:

$\begin{array}{ll}\text { perfectly elastic } & E=\infty \\ \text { relatively elastic } & E>l \\ \text { unit elastic } & E=1 \\ \text { relatively inelastic } & E<l \\ \text { perfectly inelastic } & E=0\end{array}$

these are depicted in figure 1.1

\section{Reterminants of The Price Elastlcity of Demand}

The various factors affecting the price elasticity of demand can be summarized as (Mansfield, 1970, pp. 88-90) :

1. The existence of close substitutes. Price elasticity increases with the avallability of more close substitutes.

2. Importance of the commodity in the consumer's budget. If a small fraction of the consumer's income is being spent on a specific commodity, then price fluctuations are not expected to af fect demand for that commodity, and vice versa. This means that the price elasticity of demand Increases with increasing proportion of the consumer's income being spent on the specific commodity.

3. The time span to which the demand curve pertains. It is in general accepted that demand is more elastic over a long period of time than over a 
FIGURE I.I

VARIOUS DEMAND CONFIGURATIONS

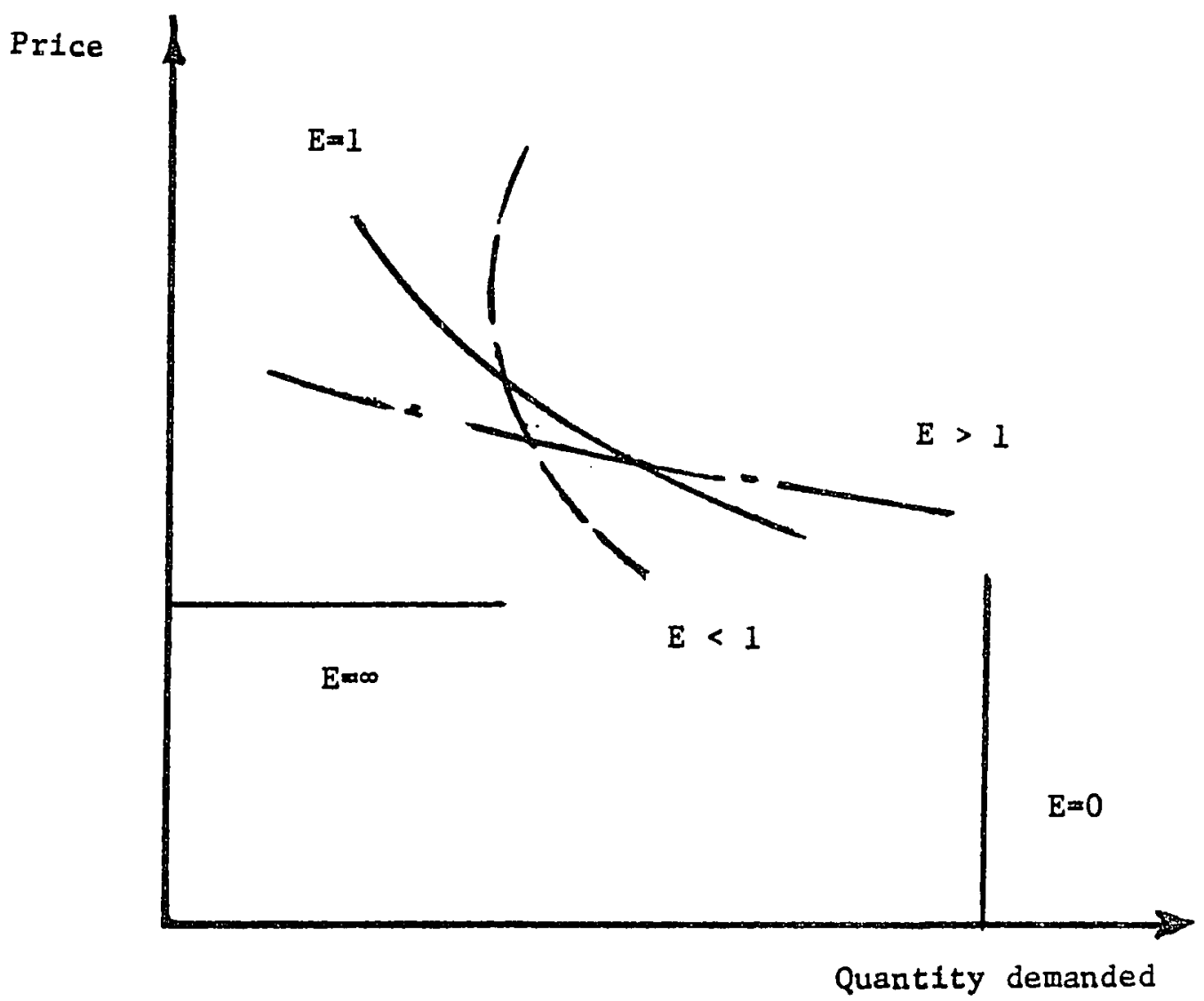


short period. In the long run, the economic system would have more chance to incorporate structural changes which would adjust themselves in such a way as to neutralize price increases.

\section{The Income Elastlclty of Demand}

Beside prices, Income is a strong determinant of demand. The Engel curves depicted in figure I.2 describe the theoretically and empirtcally accepted economic behavior of rational consumers. Panel A of figure I.2 illustrates the case where the quantity consumed of a commodity increases with income at a decreasing rate, while exhibit $B$ depicts a demand situation increasing at a decreasing rate with higher income.

A good is called "Normal" if the quantity demanded of it increases with increasing income, otherwise it is referred to as "Inferior".

The income elasticity of demand, $E(D, I)$, is defined as the percentage change in demand resulting from a one per cent change in income. In mathematical form:

$E(D, I)=d D / D / d I / I$

or equivalently

$E(D, I)=d \ln \cdot(D) / d \ln \cdot(I)$

Normal goods have positive income elasticities while inferior goods are characterized by negative income 
FIGURE I.2

ENGEL'S CURVES
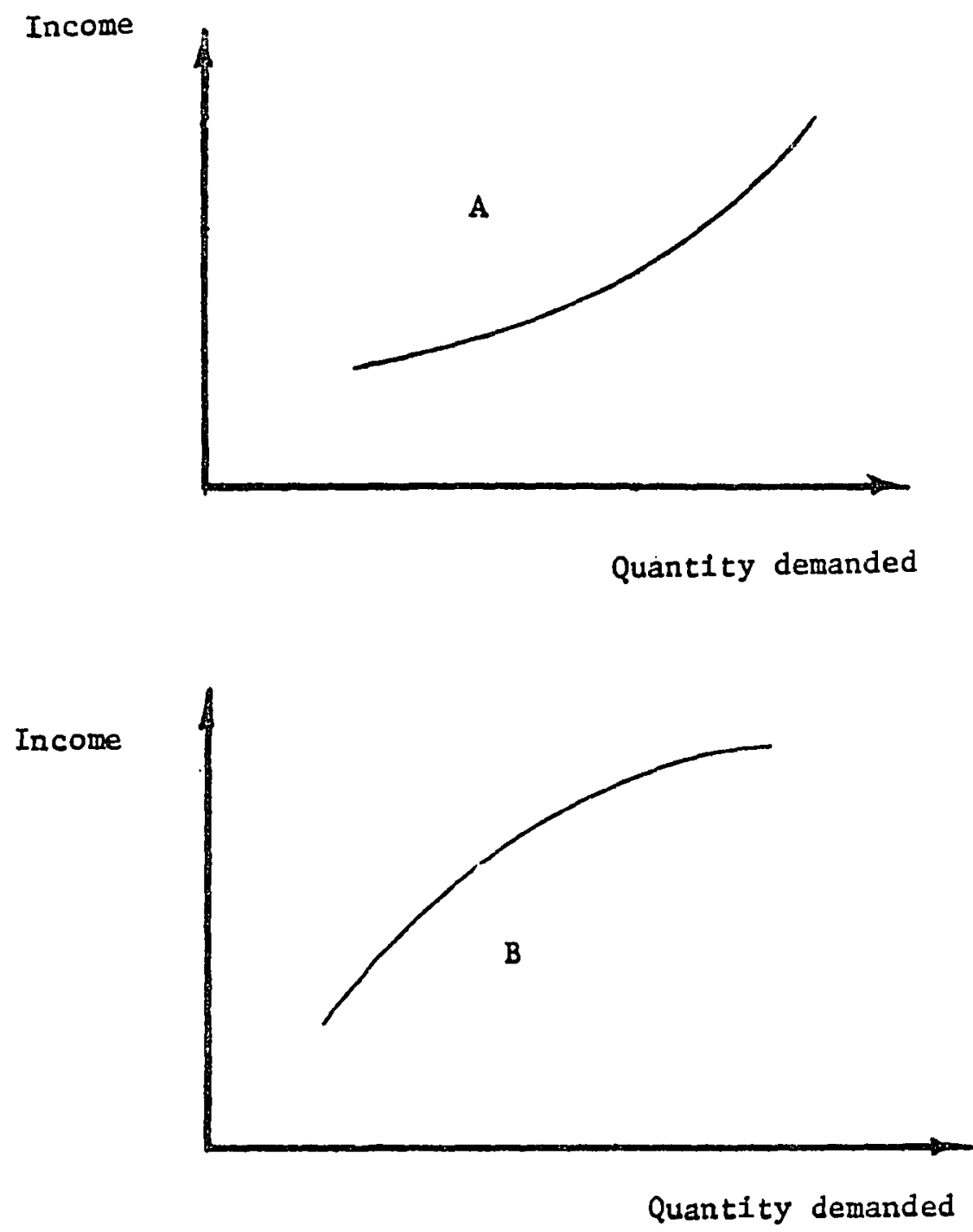
elasticitles of demand.

\section{Cross Elasticities of Demand}

A cross elasticity of demand measures the effect of changing prices of other commodities on the demand for a specific commodity.

Assuming a constant money income, and holding constant the price of commodity $X$ and all other commodities but $Y$, the cross elasticity of demand of commodity $x$ with respect to commodity $Y$ is given by:

$E(X, Y)=d D(X) / D(X) / d P(Y) / P(Y)$

or equivalently

$E(X, Y)=d \ln \cdot(D(X)) / d \ln \cdot(P(Y))$

where

$D(x)=$ Quantity demanded of commodity $x$

$P(Y)=$ Price of commodity $Y$

Based on the sign of cross elasticities, a pair of commodities inay fall in one of the two following categories:

Complements: Two commodities $X$ and $Y$ are said to be complements of each other if $E(X, Y)$ is negative. This implies that an increase in the price of $Y$ would result in $a$ decrease in the amount demanded of $x$.

Substitutes: Two commodities, $X$ and $Y$, are said to be substitutes if $E(X, Y)$ is positive. An increase in the price of $Y$, ceteris paribus, would result in an increase in 
quantity demanded of its close substitute $x$.

Theoretical Considerations Pertalning To This Work

The relevance and applicability of the theoretical considerations described in the preceding sections to the present study are discussed in this section.

The determinants of the price elasticity of demand, discussed earlier in this section, relate to the transportation sector as treated in this study in the following fashion:

1. Substitution Effect: This study is intended for short to medium time horlzon. Forecasts based on the findings of this research are assumed valid for a time span of five to ten years.

Within the forecast period, no close competitive substitutes for motor gasoline are expected to emerge. Manne (1975) predicts the commercial introduction of synthetic fuels between the years 1990 and 2020 at an estimated cost of fifteen dollars per barrel equivalent.

The above assumption suggests that the price elasticity of demand for motor gasoline would be neglegibly small. Yet, one can envisage different mechanisms through which price elasticities of demand may still exist desplte the lack of close substitutes to motor gasoline.

The main source of price elasticity would be 
through fuel conservation. The consumer may, in effect, substitute other activities for making long trips and extensive driving. Also, various structural shifts can occur in the transportation sector as a result of higher prices. Urban passengers can shift from private cars to public transportation systems, car designs may switch to higher fuel efficiency and more compactness thus reducing the specific fuel consumption of the motor vehicle,...etc.

For the planning horizon of this study, specific consumption is likely to remain unchanged. The reason for such expected constancy is that several factors, with opposing effects on fuel efficlency, are expected to occur and offset the effects of each other. One factor was pointed out by Leach (1973, p. 20) as a gradual trend toward larger engines in several western european countries, which would lead to increased specific EueI consumption per car. A second factor is the increase in fuel consumption resulting from increasing congestion as indicated by the studies of the Road Research Laboratory in Britain (Leach, 1973, p. 22). A third factor expected to have a significant impact on reducing fuel efflciency during the $1970 \mathrm{~s}$ and the $1980 \mathrm{~s}$ is the removal of lead additives and the incorporation of emission 
control devices. The Committee on Motor Vehicle Emission of The U.S. National Academy of science (1972) and the Aerospace Corporation (1971) estimate a 108 to 158 increase in specific fuel consumptoin for the average car in the U.S. and Europe during the 19808 .

Leach (1973, p. 22) indicates that most experts agree that the technicai improvements in engine design would offset the above effects, resulting in an almost constant specific fuel consumption.

For the purpose of this study, substitution through conservation, as described in the preceding paragraphs, is considered the main source of elastlcity of demand for motor gasoline.

2. Relative Importance: In order to study the effect of the relative importance of motor gasoline in the consumer's budget, the ratio of price in constant 1970 U.S. cents per gallons to the GNP per capita In constant thousand dollars per person was introauced in this thesis. Since it measures the real impact of the price as felt by the average consumer, this ratio was called the "Influential price factor or the price factor, for short, and was denoted P.F. Since P.F. Is proportional to the fraction of the consumer's income being spent on 
gasoline, it should be expected that the calculated price elasticitles of demand would increase (with a negative sign) with increasing values of P.F. The Introduction of P.F. as a measure of the variation of price elasticity of demand incorporates the Income effect in the analysis.

It is proposed at this point that as long as the price of gasoline is low relative to the per capita GNP (low values of P.F.), demand may be price Inelastic and may grow as a function of GNP and population. As P.F. reaches a certain critical threshold, the behavior reverses back to norinal causing a "Kink" after which the negative price Influence upon demand predominates. Such behavior is deplcted in figure 1.3 . 
FIGURE I.3

SUGGESTED EFFECT OF PRICE FACTOR

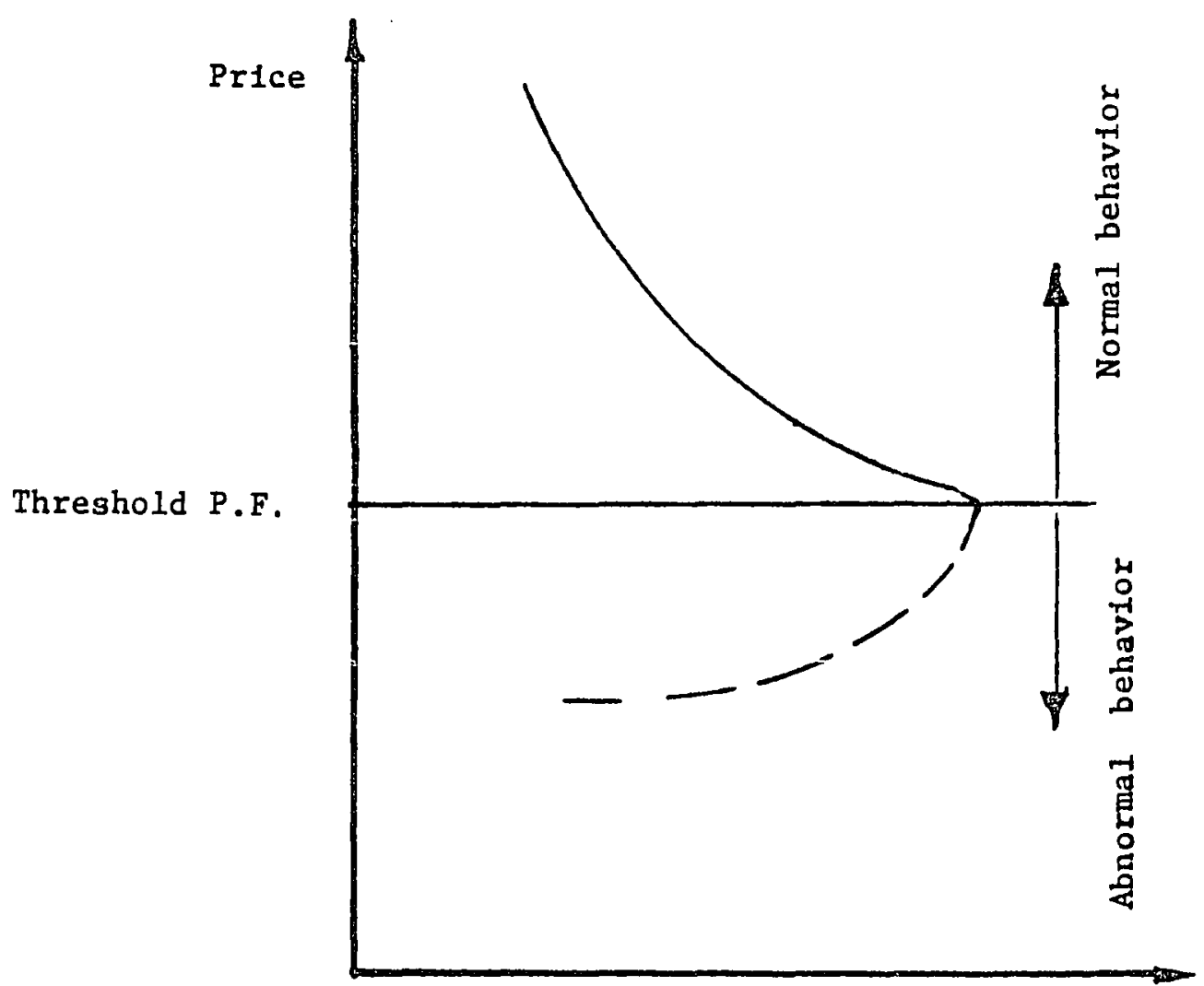

Quantity demanded 
CHADIER II

EXPERIMENTAL DESIGN AND METHODOLOGY

THE INTENSITY OF DEMAND

In order to be able to compare demand in different countries having different levels of GNP, the concept of demand Intensity is used in the analysis.

Demand intensity at time $t, D(t), 18$ defined as the total demand for motor gasoline (In thousands of gallons) divided by the GNP (1n billions of dollars). This notion has been previously used in a study of the demand for paper (Aberg, 1968) and another for steel (OECD, $1974)$.

\section{MODEL VARIABLES}

The following variables are included in the different models:

$D(t)$ the demand intengity in thousand gallons/\$billion. $d(t)$ percentage change in $D$ defined as $(D(t)-D(t-1)) / D(t-1)$.

$G(t) \quad$ GNP per capita at tine $t$ in thousand dollars.

$g(t)$ defined similar to $d(t)$.

$P(t) \quad$ price at $t$ ime $t$ in $u . S$. cents per galion. 


$$
\begin{aligned}
& p(t) \quad \text { percentage price change. } \\
& N(t) \text { number of cars at time } t .
\end{aligned}
$$

THE HY POTHESIZED MODELS

The basic model is a linear function of the explanatory varlables. Since the "correct" causal relationships between the independent variables and the demand intensity are not known a priori (they seldom are in any model), the simple linear function was chosen as the preliminary assumption. starting with a simple hypothesis, then introducing enriching additions to it as the need arises, is a highly recommended technique in modeling and simulation (Morris, 1967). In his study of prehistoric cultural change, plog (1967, p. 150) uses this approach without explicitly describing it.

For the sake of comparison, three other models were hypothesized. The mathematical forms of the four models were as follows:

Model I

$D(t)=a(0)+a(1) \cdot G(t-1)+a(2) \cdot G(t)+a(3) \cdot g(t)+a(4) \cdot D(t-1)+a(5) \cdot$ $P(t-1)+a(6) \cdot P(t)+a(7) \cdot P(t)+a(8) \cdot N(t)$

\section{Model II}

$$
\begin{aligned}
& a(t)=a(0)+a(1) \cdot G(t-1)+a(2) \cdot G(t)+a(3) \cdot g(t)+a(4) \cdot D(t-1)+a(5) \\
& P(t-1)+a(6) \cdot P(t)+a(7) \cdot p(t)+a(8) \cdot N(t) \quad[2 \cdot 2]
\end{aligned}
$$


$\ln \cdot(D(t))=\ln \cdot(a)+b \cdot \ln \cdot(G(t-1))+c \cdot \ln \cdot(G(t))+e \cdot \ln (D(t-1))+$ $f \cdot \ln (P(t-1))+h \cdot \ln (P(t))+1 . \ln \cdot(N(t))+m \cdot g(t)+n \cdot P(t) \quad[2.3]$

Mode1 IV

$d(t)=\ln \cdot(a)+b \cdot \ln \cdot(G(t-1))+c \cdot \ln \cdot(G(t))+e \cdot \ln \cdot(D(t-1))+$

f. In. $(P(t-1))+h \cdot \ln \cdot(P(t))+1 \cdot \ln (N(t))+m \cdot g(t)+n \cdot p(t)$

The above models were hypothesized in functional forms that capture the essential charecteristics of dynamic demand functions as explalned in chapter $T$.

\section{ELASTICITIES OF DEMAND}

In the following analysis it is inaintained that for the value of a variable at time $t$, the previous value, at $t-1$, is given. It follows from this assumption that:

$d p / d P(t)=1 / P(t-1)$

$d g / d G(t)=1 / G(t-1)$

From the definition of elasticity and the above relationships, we get for the first model:

$E(D(t), P(t))=(P(t) / D(t)) \cdot(a(6)+a(7) / P(t-1))$

$E(D(t), G(t))=(G(t) / D(t)) \cdot(a(2)+a(3) / G(t-1))$

Following this procedure, the different elasticities of 
demand for the different models can be derived as:

Mode 1 2:

$E(D(t), P(t))=(p(t) / d(t)) \cdot(a(7)+a(6) \cdot P(t-1))$

$E(D(t), G(t))=(g(t) / d(t)) \cdot(a(3)+a(2) \cdot G(t-1))$

Mode 1 3:

$E(D(t), P(t))=a(6)+a(7) \cdot(P(t) / P(t-1))$

$E(D(t), G(t))=a(2)+a(3) \cdot(G(t) / G(t-1))$

Model 4:

$E(D(t), P(t))=(p(t) / d(t)) \cdot(a(7)+a(6) \cdot(P(t-I) / P(t))$

$E(D(t), G(t))=(g(t) / d(t)) \cdot(a(3)+a(2) \cdot(G(t-1) / G(t))$

As will be explained in chapter III, the first model was found sat isfactory, and was chosen for further analysis. In the subsequent analysis, the lagged variables were dropped and the coefficients of the resulting model vere estimated, once with $N(t)$ included and once without. The same steps were then repeated with the lagged varlables included and the current varlables removed. The following additional elasticities were then calculated:

$E(D(t), P(t-1))=(P(t-1) / D(t)) \cdot(a(5)-a(6) \cdot P(t) / P(t-1))$ 
$E(D(t), G(t-1))=(G(t-1) / D(t)) \cdot(a(1)-a(2) \cdot G(t) / G(t-1)) \quad[2 \cdot 16]$

DATA DESCRIPTION AND ANALYSIS

Table 2.1 displays the time series data of 15 OECD countries covering the pertod 1965-1975. The OECD is comprised of twenty countries. Two of the countries, viz. Greece and Turkey, had Incomplete data and were excluded from the analysis. For the purpose of validating the research's results, three other countziles of the OECD were kept for testing the forecasting accuracy of the resulting formulas. These "control" countrles were France, Ireland and Japan.

Population and GNP figures were complied from different lssues of the OECD Main Economic Indicators: Historical statistics. The GNP data are given in constant 1970 U.S. dollars, converted by the annual exchange rates and the GNP price deflators corresponding to each country. Price figures were compiled from different issues of the International Petroleum Annual published by the U.S. Bureau of Mines. The prices in that reference are given in current U.S. dollars adjusted by annual exchange rates. The data were converted to constant 1970 dollars using the consumer price indexes given in table 2.2. The price data 
TAERLE TI.1

TIME SEFIES DATA FOR 15 OECD COUNTRIES

\begin{tabular}{|c|c|c|c|c|c|c|c|c|c|c|c|}
\hline COUNTRY & YEAR & $6(t-1)$ & $G(t)$ & $s(t)$ & $n(t-1)$ & $\mathbb{E}(\dot{\tau})$ & $\sigma(t)$ & $P(t-1)$ & $F^{\prime}(t)$ & $F(t)$ & $N(t)$ \\
\hline AUSTRIA & $\begin{array}{l}1966 \\
1967 \\
1968 \\
1969 \\
1970 \\
1971 \\
1972 \\
1973 \\
1974 \\
1975\end{array}$ & $\begin{array}{l}1.54 \\
1.57 \\
1.61 \\
1.71 \\
1.80 \\
1.93 \\
2.03 \\
2.15 \\
2.26 \\
2.35\end{array}$ & $\begin{array}{l}1.57 \\
1.61 \\
1.71 \\
1.80 \\
1.93 \\
2.03 \\
2.15 \\
2.26 \\
2.35 \\
2.30\end{array}$ & $\begin{array}{l}0.0195 \\
0.0255 \\
0.0621 \\
0.0526 \\
0.0722 \\
0.0518 \\
0.0591 \\
0.0512 \\
0.0398 \\
-.0213\end{array}$ & $\begin{array}{l}509.00 \\
566.90 \\
605.18 \\
615.79 \\
621.11 \\
634.60 \\
685.00 \\
724.64 \\
750.65 \\
659.86\end{array}$ & $\begin{array}{l}566.90 \\
605.18 \\
615.29 \\
621.11 \\
634.60 \\
695.00 \\
724.64 \\
750.65 \\
659.86 \\
709.64\end{array}$ & $\begin{array}{l}0.1137 \\
0.0675 \\
0.0167 \\
0.0095 \\
0.0217 \\
0.0794 \\
0.0579 \\
0.0359 \\
-.1209 \\
-.0661\end{array}$ & $\begin{array}{l}58.99 \\
58.83 \\
56.84 \\
55.88 \\
54.86 \\
53.15 \\
53.30 \\
56.20 \\
76.57 \\
86.49\end{array}$ & $\begin{array}{r}58.83 \\
56.94 \\
55.88 \\
54.86 \\
53.15 \\
53.30 \\
56.20 \\
76.57 \\
96.49 \\
107.03\end{array}$ & $\begin{array}{l}-.0020 \\
-.0330 \\
-.0160 \\
-.0180 \\
-.0310 \\
0.0028 \\
0.0540 \\
0.3620 \\
0.2600 \\
0.1092\end{array}$ & $\begin{array}{l}0.9849 \\
1.0765 \\
1.1672 \\
1.2359 \\
1.3242 \\
1.5351 \\
1.6052 \\
1.7111 \\
1.7875 \\
1.9837\end{array}$ \\
\hline BELGIUM & $\begin{array}{l}1966 \\
1967 \\
1968 \\
1969 \\
1970 \\
1971 \\
1972 \\
1973 \\
1974 \\
1975\end{array}$ & $\begin{array}{l}2.16 \\
2.21 \\
2.27 \\
2.37 \\
2.53 \\
2.68 \\
2.77 \\
2.91 \\
3.09 \\
3.20\end{array}$ & $\begin{array}{l}2.21 \\
2.27 \\
2.37 \\
2.53 \\
2.68 \\
2.77 \\
2.91 \\
3.09 \\
3.20 \\
3.13\end{array}$ & $\begin{array}{l}0.0231 \\
0.0271 \\
0.0441 \\
0.0675 \\
0.0593 \\
0.0336 \\
0.0505 \\
0.0619 \\
0.0356 \\
-.0219\end{array}$ & $\begin{array}{l}439.77 \\
419.73 \\
447.61 \\
472.39 \\
480.08 \\
492.16 \\
496.00 \\
512.73 \\
491.98 \\
461.56\end{array}$ & $\begin{array}{l}419.73 \\
447.61 \\
472.39 \\
480.08 \\
492.16 \\
495.00 \\
512.73 \\
491.98 \\
461.56 \\
519.44\end{array}$ & $\begin{array}{l}-.0456 \\
0.0664 \\
0.0554 \\
0.0163 \\
0.0252 \\
0.0078 \\
0.0337 \\
-.0405 \\
-.0618 \\
0.1254\end{array}$ & $\begin{array}{r}73.63 \\
71.83 \\
71.03 \\
70.27 \\
68.90 \\
67.35 \\
69.32 \\
75.00 \\
99.07 \\
109.88\end{array}$ & $\begin{array}{r}71.83 \\
71.03 \\
70.27 \\
69.90 \\
67.35 \\
69.32 \\
75.00 \\
99.07 \\
109.88 \\
88.96\end{array}$ & $\begin{array}{l}-.0244 \\
-.0111 \\
-.0107 \\
-.0195 \\
-.0225 \\
0.0292 \\
0.0819 \\
0.3209 \\
0.1091 \\
-.1904\end{array}$ & $\begin{array}{l}1.6723 \\
1.8120 \\
2.0854 \\
2.2024 \\
2.3507 \\
2.4448 \\
2.5752 \\
2.6700 \\
2.8190 \\
3.2085\end{array}$ \\
\hline DENATARK & $\begin{array}{l}1966 \\
1967 \\
1365 \\
1969 \\
1970 \\
1971 \\
1972 \\
1973 \\
1974 \\
1975\end{array}$ & $\begin{array}{l}2.52 \\
2.65 \\
2.72 \\
2.85 \\
3.08 \\
3.16 \\
3.25 \\
3.37 \\
3.45 \\
3.44\end{array}$ & $\begin{array}{l}2.65 \\
2.72 \\
2.85 \\
3.08 \\
3.16 \\
3.25 \\
3.37 \\
3.45 \\
3.44 \\
3.41\end{array}$ & $\begin{array}{l}0.0115 \\
0.0264 \\
0.0478 \\
0.0807 \\
0.0260 \\
0.0285 \\
0.0369 \\
0.0237 \\
-.0029 \\
-.0087\end{array}$ & $\begin{array}{l}538.40 \\
568.09 \\
580.58 \\
569.12 \\
567.71 \\
553.17 \\
554.31 \\
545.96 \\
542.49 \\
492.58\end{array}$ & $\begin{array}{l}568.09 \\
530.58 \\
569.12 \\
567.71 \\
553.17 \\
554.31 \\
545.96 \\
542.49 \\
492.58 \\
525.98\end{array}$ & $\begin{array}{l}0.0551 \\
0.0220 \\
-.0197 \\
-.0025 \\
-.0256 \\
0.0021 \\
-.0151 \\
-.0064 \\
-.0920 \\
0.0678\end{array}$ & $\begin{array}{l}82.34 \\
78.96 \\
75.56 \\
71.12 \\
69.77 \\
67.35 \\
67.94 \\
67.82 \\
85.16 \\
96.34\end{array}$ & $\begin{array}{l}78.96 \\
75.56 \\
71.12 \\
69.77 \\
67.35 \\
67.94 \\
67.22 \\
25.16 \\
96.34 \\
87.93\end{array}$ & $\begin{array}{l}-.0410 \\
-.0431 \\
-.0588 \\
-.0190 \\
-.0347 \\
0.0088 \\
-.0018 \\
0.2557 \\
0.1313 \\
-.0873\end{array}$ & $\begin{array}{l}1.0640 \\
1.1360 \\
1.2143 \\
1.2858 \\
1.3290 \\
1.3690 \\
1.4077 \\
1.4069 \\
1.4750 \\
1.6202\end{array}$ \\
\hline
\end{tabular}


TABLE II.1 CONTD.

TIME SERIES DATA FOR 15 OECD COUNTRIES

\begin{tabular}{|c|c|c|c|c|c|c|c|c|c|c|c|}
\hline COUNTRY & YEAF: & $G(t-1)$ & $G(t)$ & $s(t)$ & $n(t-1)$ & $I(t)$ & $d(t)$ & $P(t-1)$ & $P(t)$ & $p(t)$ & $N(t)$ \\
\hline GERMANY & $\begin{array}{l}1966 \\
1967 \\
1968 \\
1969 \\
1970 \\
1971 \\
1972 \\
1973 \\
1974 \\
1975\end{array}$ & $\begin{array}{l}2.55 \\
2.61 \\
2.59 \\
2.77 \\
2.96 \\
3.11 \\
3.16 \\
3.25 \\
3.40 \\
3.42\end{array}$ & $\begin{array}{l}2.61 \\
2.59 \\
2.77 \\
2.96 \\
3.11 \\
3.16 \\
3.25 \\
3.40 \\
3.42 \\
3.32\end{array}$ & $\begin{array}{l}0.0235 \\
-.0077 \\
0.0695 \\
0.0686 \\
0.0507 \\
0.0161 \\
0.0285 \\
0.0462 \\
0.0059 \\
-.0292\end{array}$ & $\begin{array}{l}409.05 \\
440.91 \\
464.90 \\
460.06 \\
469.20 \\
485.92 \\
523.52 \\
534.19 \\
518.14 \\
501.80\end{array}$ & $\begin{array}{l}440.91 \\
464.96 \\
460.06 \\
469.20 \\
485.92 \\
523.52 \\
534.19 \\
518.14 \\
501.80 \\
565.42\end{array}$ & $\begin{array}{l}0.0779 \\
0.0545 \\
-.0105 \\
0.0199 \\
0.0356 \\
0.0774 \\
0.0204 \\
-.0300 \\
-.0315 \\
0.1268\end{array}$ & $\begin{array}{r}64.98 \\
63.68 \\
63.69 \\
62.95 \\
62.64 \\
61.40 \\
66.00 \\
71.65 \\
104.84 \\
103.58\end{array}$ & $\begin{array}{r}63.68 \\
63.69 \\
62.95 \\
62.64 \\
61.40 \\
66.00 \\
71.65 \\
104.84 \\
103.58 \\
95.84\end{array}$ & $\begin{array}{l}-.0200 \\
0.0002 \\
-.0116 \\
-.0049 \\
-.0198 \\
0.0749 \\
0.0856 \\
0.4632 \\
-.0120 \\
-.0747\end{array}$ & $\begin{array}{l}11.6731 \\
12.3251 \\
13.1138 \\
14.2977 \\
15.6049 \\
16.6335 \\
17.6498 \\
18.3854 \\
18.6592 \\
20.8743\end{array}$ \\
\hline ITALY & $\begin{array}{l}1966 \\
1967 \\
1968 \\
1969 \\
1970 \\
1971 \\
1972 \\
1973 \\
1974 \\
1975\end{array}$ & $\begin{array}{l}1.33 \\
1.41 \\
1.50 \\
1.57 \\
1.65 \\
1.72 \\
1.74 \\
1.78 \\
1.88 \\
1.93\end{array}$ & $\begin{array}{l}1.41 \\
1.50 \\
1.57 \\
1.65 \\
1.72 \\
1.74 \\
1.78 \\
1.88 \\
1.93 \\
1.84\end{array}$ & $\begin{array}{l}0.0601 \\
0.0638 \\
0.0467 \\
0.0510 \\
0.0424 \\
0.0116 \\
0.0230 \\
0.0562 \\
0.0266 \\
-.0466\end{array}$ & $\begin{array}{l}490.18 \\
506.68 \\
524.57 \\
549.73 \\
562.02 \\
577.40 \\
594.11 \\
624.57 \\
626.27 \\
563.67\end{array}$ & $\begin{array}{l}506.68 \\
524.57 \\
549.73 \\
562.02 \\
577.40 \\
594.11 \\
624.57 \\
626.27 \\
563.67 \\
626.55\end{array}$ & $\begin{array}{l}0.0337 \\
0.0353 \\
0.0480 \\
0.0224 \\
0.0274 \\
0.0289 \\
0.0513 \\
0.0027 \\
-.1000 \\
0.1116\end{array}$ & $\begin{array}{r}80.59 \\
81.37 \\
80.95 \\
82.38 \\
82.72 \\
81.05 \\
90.60 \\
92.10 \\
83.10 \\
118.11\end{array}$ & $\begin{array}{r}81.37 \\
80.95 \\
82.38 \\
82.72 \\
81.05 \\
90.60 \\
92.10 \\
83.10 \\
118.11 \\
99.85\end{array}$ & $\begin{array}{l}0.0097 \\
-.0052 \\
0.0177 \\
0.0041 \\
-.0202 \\
0.1178 \\
0.0166 \\
-.0977 \\
0.4213 \\
-.1546\end{array}$ & $\begin{array}{r}7.0028 \\
8.0485 \\
8.9766 \\
9.8626 \\
11.1384 \\
12.3122 \\
13.5161 \\
14.5078 \\
15.4360 \\
16.5757\end{array}$ \\
\hline LUXEMBOURG & $\begin{array}{l}1966 \\
1967 \\
1968 \\
1969 \\
1970 \\
1971 \\
1972 \\
1973 \\
1974 \\
1975\end{array}$ & $\begin{array}{l}2.68 \\
2.72 \\
2.72 \\
2.82 \\
3.04 \\
3.15 \\
3.19 \\
3.30 \\
3.48 \\
3.56\end{array}$ & $\begin{array}{l}2.72 \\
2.72 \\
2.82 \\
3.04 \\
3.15 \\
3.19 \\
3.30 \\
3.48 \\
3.56 \\
3.26\end{array}$ & $\begin{array}{l}0.0147 \\
0.0000 \\
0.0368 \\
0.0780 \\
0.0362 \\
0.0127 \\
0.0345 \\
0.0545 \\
0.0230 \\
-.0843\end{array}$ & $\begin{array}{l}521.04 \\
527.30 \\
542.46 \\
539.61 \\
536.80 \\
554.37 \\
611.95 \\
670.40 \\
739.06 \\
693.13\end{array}$ & $\begin{array}{l}527.30 \\
542.46 \\
539.61 \\
536.80 \\
554.37 \\
611.95 \\
670.40 \\
739.06 \\
693.13 \\
885.15\end{array}$ & $\begin{array}{l}0.0120 \\
0.0288 \\
-.0053 \\
-.0052 \\
0.0327 \\
0.1039 \\
0.0955 \\
0.1024 \\
-.0621 \\
0.2770\end{array}$ & $\begin{array}{l}63.11 \\
62.50 \\
62.62 \\
62.39 \\
62.30 \\
60.85 \\
59.50 \\
56.40 \\
76.88 \\
88.59\end{array}$ & $\begin{array}{l}62.50 \\
62.62 \\
62.39 \\
62.30 \\
60.85 \\
59.50 \\
56.40 \\
76.88 \\
88.59 \\
77.77\end{array}$ & $\begin{array}{l}-.0097 \\
0.0019 \\
-.0037 \\
-.0014 \\
-.0233 \\
-.0222 \\
-.0521 \\
0.3631 \\
0.1523 \\
-.1221\end{array}$ & $\begin{array}{l}0.0898 \\
0.0962 \\
0.9620 \\
0.1097 \\
0.1173 \\
0.1223 \\
0.1274 \\
0.1325 \\
0.1391 \\
0.1574\end{array}$ \\
\hline
\end{tabular}


TAELE II, 1 CONTI.

TIME SEFIES IATA FOK 15 OECI COUNTRIES

\begin{tabular}{|c|c|c|c|c|c|c|c|c|c|c|c|}
\hline COUNTRY & YEAR & $G(t-1)$ & $G(t)$ & $s(t)$ & $D(t-1)$ & $I I(t)$ & $d(t)$ & $F(t-1)$ & $P(t)$ & $p(t)$ & $N(t)$ \\
\hline NETHEFL. & $\begin{array}{l}1966 \\
1967 \\
1968 \\
1969 \\
1970 \\
1971 \\
1972 \\
1973 \\
1974 \\
1975\end{array}$ & $\begin{array}{l}1.97 \\
2.00 \\
2.09 \\
2.20 \\
2.32 \\
2.43 \\
2.51 \\
2.58 \\
2.71 \\
2.75\end{array}$ & $\begin{array}{l}2.00 \\
2.09 \\
2.20 \\
2.32 \\
2.43 \\
2.51 \\
2.58 \\
2.71 \\
2.75 \\
2.70\end{array}$ & $\begin{array}{l}0.0152 \\
0.0450 \\
0.0526 \\
0.0545 \\
0.0474 \\
0.0329 \\
0.0279 \\
0.0504 \\
0.0148 \\
-.0182\end{array}$ & $\begin{array}{l}466.56 \\
500.08 \\
517.09 \\
538.71 \\
530.35 \\
551.19 \\
564.03 \\
572.33 \\
562.22 \\
494.16\end{array}$ & $\begin{array}{l}500.08 \\
517.09 \\
538.71 \\
530.35 \\
551.19 \\
554.03 \\
572.33 \\
562.22 \\
494.16 \\
542.10\end{array}$ & $\begin{array}{l}0.0718 \\
0.0340 \\
0.0418 \\
-.0155 \\
0.0393 \\
0.0233 \\
0.0147 \\
-.0177 \\
-.1211 \\
0.0970\end{array}$ & $\begin{array}{r}67.55 \\
65.99 \\
65.77 \\
65.36 \\
62.61 \\
62.15 \\
65.77 \\
74.16 \\
92.85 \\
101.24\end{array}$ & $\begin{array}{r}65.99 \\
65.77 \\
65.36 \\
62.61 \\
62.15 \\
65.77 \\
74.16 \\
92.85 \\
101.24 \\
94.38\end{array}$ & $\begin{array}{l}-.0231 \\
-.0033 \\
-.0062 \\
-.0421 \\
-.0073 \\
0.0582 \\
0.1276 \\
0.2520 \\
0.0904 \\
-.0678\end{array}$ & $\begin{array}{l}1.7643 \\
1.9797 \\
2.4097 \\
2.5330 \\
2.8375 \\
3.0512 \\
3.2777 \\
3.5799 \\
3.7970 \\
4.2834\end{array}$ \\
\hline NORWAY & $\begin{array}{l}1966 \\
1967 \\
1968 \\
1969 \\
1970 \\
1971 \\
1972 \\
1973 \\
1974 \\
1975\end{array}$ & $\begin{array}{l}2.40 \\
2.49 \\
2.60 \\
2.69 \\
2.80 \\
2.88 \\
2.99 \\
3.12 \\
3.22 \\
3.37\end{array}$ & $\begin{array}{l}2.49 \\
2.60 \\
2.69 \\
2.80 \\
2.88 \\
2.99 \\
3.12 \\
3.22 \\
3.37 \\
3.46\end{array}$ & $\begin{array}{l}0.0375 \\
0.0442 \\
0.0346 \\
0.0409 \\
0.0286 \\
0.0382 \\
0.0435 \\
0.0321 \\
0.0466 \\
0.0267\end{array}$ & $\begin{array}{l}416.32 \\
422.16 \\
432.12 \\
436.11 \\
457.82 \\
455.89 \\
482.16 \\
486.65 \\
495.51 \\
436.01\end{array}$ & $\begin{array}{l}422.16 \\
432.12 \\
435.11 \\
457.82 \\
455.89 \\
482.16 \\
486.65 \\
495.51 \\
436.01 \\
476.62\end{array}$ & $\begin{array}{l}0.0140 \\
.0 .0236 \\
0.0092 \\
0.0498 \\
-.0042 \\
0.0576 \\
0.0093 \\
0.0182 \\
-.1201 \\
0.0931\end{array}$ & $\begin{array}{r}72.78 \\
73.51 \\
72.76 \\
72.30 \\
72.96 \\
67.70 \\
75.38 \\
75.39 \\
70.45 \\
110.71\end{array}$ & $\begin{array}{r}73.51 \\
72.76 \\
72.30 \\
72.96 \\
67.70 \\
75.38 \\
75.39 \\
70.45 \\
110.71 \\
94.00\end{array}$ & $\begin{array}{l}0.0100 \\
-.0102 \\
-.0063 \\
0.0091 \\
-.0721 \\
0.1134 \\
0.0001 \\
-.0655 \\
0.5715 \\
-.1509\end{array}$ & $\begin{array}{l}0.7559 \\
0.7110 \\
0.7746 \\
0.8495 \\
0.9033 \\
0.9644 \\
1.0256 \\
1.0873 \\
1.0437 \\
1.1608\end{array}$ \\
\hline PORTUGAL & $\begin{array}{l}1966 \\
1967 \\
1968 \\
1969 \\
1970 \\
1971 \\
1972 \\
1973 \\
1974 \\
1975\end{array}$ & $\begin{array}{l}0.50 \\
0.52 \\
0.56 \\
0.62 \\
0.65 \\
0.71 \\
0.70 \\
0.83 \\
0.92 \\
0.91\end{array}$ & $\begin{array}{l}0.52 \\
0.56 \\
0.62 \\
0.65 \\
0.71 \\
0.76 \\
0.83 \\
0.92 \\
0.91 \\
0.82\end{array}$ & $\begin{array}{l}0.0400 \\
0.0769 \\
0.1071 \\
0.0484 \\
0.0923 \\
0.0704 \\
0.0921 \\
0.1084 \\
-.0109 \\
-.0989\end{array}$ & $\begin{array}{l}356.61 \\
380.74 \\
394.49 \\
396.39 \\
435.29 \\
440.57 \\
485.75 \\
494.54 \\
519.29 \\
486.23\end{array}$ & $\begin{array}{l}380.74 \\
394.49 \\
396.39 \\
435.29 \\
440.57 \\
485.75 \\
494.54 \\
519.29 \\
486.23 \\
594.57\end{array}$ & $\begin{array}{l}0.0677 \\
0.0361 \\
0.0048 \\
0.0981 \\
0.0121 \\
0.1025 \\
0.0181 \\
0.0500 \\
-.0637 \\
0.2228\end{array}$ & $\begin{array}{r}101.77 \\
98.15 \\
95.59 \\
92.42 \\
87.12 \\
79.65 \\
72.92 \\
69.53 \\
65.80 \\
86.94\end{array}$ & $\begin{array}{l}98.15 \\
95.59 \\
92.42 \\
87.12 \\
79.65 \\
72.92 \\
69.53 \\
65.80 \\
86.94 \\
86.49\end{array}$ & $\begin{array}{l}-.0356 \\
-.0261 \\
-.0332 \\
-.0573 \\
-.0857 \\
-.0845 \\
-.0465 \\
-.0536 \\
0.3213 \\
-.0052\end{array}$ & $\begin{array}{l}0.3700 \\
0.4085 \\
0.4470 \\
0.5020 \\
0.5600 \\
0.7031 \\
0.8462 \\
0.9420 \\
1.0920 \\
1.2800\end{array}$ \\
\hline
\end{tabular}


TAELE II.A CONTII.

TIME SERIES IIATA FOR 15 OECU COUNTRIES

\begin{tabular}{|c|c|c|c|c|c|c|c|c|c|c|c|}
\hline COUNTEY & YEAFi & $G(t-1)$ & $G(t)$ & $g(t)$ & {$[1(t-1)$} & {$[1(t)$} & $d(t)$ & $P(t-1)$ & $P(t)$ & $p(t)$ & $N(t)$ \\
\hline SPAIN & $\begin{array}{l}1966 \\
1967 \\
1968 \\
1969 \\
1970 \\
1971 \\
1972 \\
1973 \\
1974 \\
1975\end{array}$ & $\begin{array}{l}0.85 \\
0.91 \\
0.94 \\
0.98 \\
1.04 \\
1.09 \\
1.14 \\
1.22 \\
1.31 \\
1.37\end{array}$ & $\begin{array}{l}0.91 \\
0.74 \\
0.98 \\
1.04 \\
1.09 \\
1.14 \\
1.22 \\
1.31 \\
1.37 \\
1.37\end{array}$ & $\begin{array}{l}0.0706 \\
0.0330 \\
0.0426 \\
0.0612 \\
0.0481 \\
0.0459 \\
0.0702 \\
0.0738 \\
0.0458 \\
0.0000\end{array}$ & $\begin{array}{l}278.05 \\
296.75 \\
332.99 \\
367.77 \\
399.95 \\
436.45 \\
460.04 \\
487.58 \\
510.94 \\
505.02\end{array}$ & $\begin{array}{l}296.75 \\
332.99 \\
369.77 \\
399.95 \\
436.45 \\
460.04 \\
487.58 \\
510.94 \\
505.02 \\
522.49\end{array}$ & $\begin{array}{l}0.0673 \\
0.1221 \\
0.1105 \\
0.0816 \\
0.0913 \\
0.0541 \\
0.0599 \\
0.0479 \\
-.0116 \\
0.0346\end{array}$ & $\begin{array}{l}76.82 \\
71.41 \\
66.14 \\
62.20 \\
60.04 \\
56.00 \\
57.71 \\
55.63 \\
67.76 \\
84.38\end{array}$ & $\begin{array}{l}71.41 \\
66.14 \\
62.20 \\
60.04 \\
56.00 \\
57.71 \\
55.63 \\
67.76 \\
84.38 \\
68.87\end{array}$ & $\begin{array}{l}-.0704 \\
-.0738 \\
-.0596 \\
-.0347 \\
-.0673 \\
0.0305 \\
-.0360 \\
0.2180 \\
0.2453 \\
-.1838\end{array}$ & $\begin{array}{l}1.5384 \\
1.8840 \\
2.2535 \\
2.6870 \\
3.1305 \\
3.5840 \\
4.1153 \\
4.7370 \\
5.2994 \\
5.9649\end{array}$ \\
\hline SWEDEN & $\begin{array}{l}1966 \\
1967 \\
1968 \\
1969 \\
1970 \\
1971 \\
1972 \\
1973 \\
1974 \\
1975\end{array}$ & $\begin{array}{l}3.52 \\
3.61 \\
3.67 \\
3.76 \\
3.96 \\
4.10 \\
4.10 \\
4.19 \\
4.33 \\
4.49\end{array}$ & $\begin{array}{l}3.61 \\
3.67 \\
3.76 \\
3.96 \\
4.10 \\
4.10 \\
4.19 \\
4.33 \\
4.49 \\
4.51\end{array}$ & $\begin{array}{l}0.0256 \\
0.0166 \\
0.0245 \\
0.0532 \\
0.0354 \\
0.0000 \\
0.0220 \\
0.0334 \\
0.0370 \\
0.0045\end{array}$ & $\begin{array}{l}469.45 \\
472.13 \\
479.58 \\
487.02 \\
484.75 \\
482.10 \\
489.54 \\
496.58 \\
507.42 \\
449.13\end{array}$ & $\begin{array}{l}472.13 \\
479.58 \\
487.02 \\
484.75 \\
482.10 \\
489.54 \\
496.58 \\
507.42 \\
449.13 \\
504.13\end{array}$ & $\begin{array}{l}0.0057 \\
0.0158 \\
0.0155 \\
-.0047 \\
-.0055 \\
0.0154 \\
0.0144 \\
0.0218 \\
-.1149 \\
0.1225\end{array}$ & $\begin{array}{l}74.44 \\
71.02 \\
70.35 \\
70.49 \\
70.61 \\
67.20 \\
69.67 \\
72.32 \\
85.17 \\
89.89\end{array}$ & $\begin{array}{l}71.02 \\
70.35 \\
70.48 \\
70.61 \\
67.20 \\
69.67 \\
72.32 \\
85.17 \\
89.89 \\
85.54\end{array}$ & $\begin{array}{l}-.0459 \\
-.0094 \\
0.0018 \\
0.0018 \\
-.0483 \\
0.0368 \\
0.0380 \\
0.1777 \\
0.0554 \\
-.0484\end{array}$ & $\begin{array}{l}2.0283 \\
2.1169 \\
2.2226 \\
2.3498 \\
2.4465 \\
2.5229 \\
2.6180 \\
2.6668 \\
2.8092 \\
3.1172\end{array}$ \\
\hline SWITZERL. & $\begin{array}{l}1966 \\
1967 \\
1968 \\
1969 \\
1970 \\
1971 \\
1972 \\
1973 \\
1974 \\
1975\end{array}$ & $\begin{array}{l}2.93 \\
2.99 \\
3.01 \\
3.10 \\
3.24 \\
3.35 \\
3.46 \\
3.54 \\
3.62 \\
3.67\end{array}$ & $\begin{array}{l}2.99 \\
3.01 \\
3.10 \\
3.24 \\
3.35 \\
3.46 \\
3.54 \\
3.62 \\
3.67 \\
3.41\end{array}$ & $\begin{array}{l}0.0205 \\
0.0067 \\
0.0299 \\
0.0452 \\
0.0340 \\
0.0328 \\
0.0231 \\
0.0226 \\
0.0138 \\
-.0708\end{array}$ & $\begin{array}{l}493.81 \\
514.37 \\
542.24 \\
542.05 \\
552.20 \\
578.08 \\
618.97 \\
627.55 \\
620.32 \\
598.48\end{array}$ & $\begin{array}{l}514.37 \\
542.24 \\
542.05 \\
552.20 \\
578.08 \\
618.97 \\
627.55 \\
620.32 \\
558.48 \\
642.95\end{array}$ & $\begin{array}{l}0.0416 \\
0.0542 \\
-.0004 \\
0.0187 \\
0.0469 \\
0.0707 \\
0.0139 \\
-.0115 \\
-.0352 \\
0.0743\end{array}$ & $\begin{array}{l}55.98 \\
54.75 \\
53.92 \\
53.88 \\
53.73 \\
53.00 \\
55.82 \\
62.94 \\
74.96 \\
84.38\end{array}$ & $\begin{array}{l}54.75 \\
53.92 \\
53.88 \\
53.73 \\
53.00 \\
55.82 \\
62.94 \\
74.96 \\
84.38 \\
93.92\end{array}$ & $\begin{array}{l}-.0220 \\
-.0152 \\
-.0007 \\
-.0028 \\
-.0136 \\
0.0532 \\
0.1276 \\
0.1910 \\
0.1257 \\
0.1131\end{array}$ & $\begin{array}{l}1.1192 \\
1.1973 \\
1.3859 \\
1.3893 \\
1.5300 \\
1.6248 \\
1.7310 \\
1.8221 \\
1.8995 \\
2.0507\end{array}$ \\
\hline
\end{tabular}


TABLE II.1 CONTII.

TIME SERIES DATA FCR 15 OECD COUNTRIES

\begin{tabular}{|c|c|c|c|c|c|c|c|c|c|c|c|}
\hline COUNTRY & YEAR & $G(t-1)$ & $G(t)$ & $g(t)$ & $\mathrm{n}(\mathrm{t}-1)$ & $I(t)$ & $d(t)$ & $P(t-1)$ & $F(t)$ & $P(t)$ & $N(t)$ \\
\hline U.K. & $\begin{array}{l}1966 \\
1967 \\
1968 \\
1967 \\
1970 \\
1971 \\
1972 \\
1973 \\
1974 \\
1975\end{array}$ & $\begin{array}{l}1.99 \\
2.02 \\
2.05 \\
2.11 \\
2.15 \\
2.19 \\
2.24 \\
2.29 \\
2.42 \\
2.42\end{array}$ & $\begin{array}{l}2.02 \\
2.05 \\
2.11 \\
2.15 \\
2.19 \\
2.24 \\
2.29 \\
2.42 \\
2.42 \\
2.39\end{array}$ & $\begin{array}{l}0.0151 \\
0.0149 \\
0.0293 \\
0.0190 \\
0.0186 \\
0.0228 \\
0.0223 \\
0.0568 \\
0.0000 \\
-.0124\end{array}$ & $\begin{array}{l}580.99 \\
601.54 \\
628.81 \\
643.32 \\
650.33 \\
674.08 \\
691.09 \\
715.88 \\
719.27 \\
698.64\end{array}$ & $\begin{array}{l}601.54 \\
628.81 \\
643.32 \\
650.33 \\
674.08 \\
671.09 \\
715.88 \\
719.27 \\
6.98 .64 \\
692.50\end{array}$ & $\begin{array}{l}0.0354 \\
0.0453 \\
0.0231 \\
0.0109 \\
0.0365 \\
0.0252 \\
0.0359 \\
0.0047 \\
-.0287 \\
-.0088\end{array}$ & $\begin{array}{l}74.84 \\
73.16 \\
72.44 \\
70.24 \\
67.63 \\
64.50 \\
60.97 \\
58.36 \\
62.11 \\
85.92\end{array}$ & $\begin{array}{l}73.16 \\
72.44 \\
70.24 \\
67.63 \\
64.50 \\
60.97 \\
58.36 \\
62.11 \\
85.92 \\
69.96\end{array}$ & $\begin{array}{l}-.0224 \\
-.0098 \\
-.0304 \\
-.0372 \\
-.0463 \\
-.0547 \\
-.0428 \\
0.0643 \\
0.3834 \\
-.1858\end{array}$ & $\begin{array}{l}11.6226 \\
12.4873 \\
12.7853 \\
13.4053 \\
13.7025 \\
14.2390 \\
14.9096 \\
15.4820 \\
15.8644 \\
17.3303\end{array}$ \\
\hline CANAIIA & $\begin{array}{l}1966 \\
1967 \\
1968 \\
1969 \\
1970 \\
1971 \\
1972 \\
1973 \\
1974 \\
1975\end{array}$ & $\begin{array}{l}3.37 \\
3.73 \\
3.78 \\
3.65 \\
4.05 \\
3.88 \\
4.09 \\
4.27 \\
4.51 \\
4.58\end{array}$ & $\begin{array}{l}3.73 \\
3.78 \\
3.68 \\
4.05 \\
3.88 \\
4.09 \\
4.27 \\
4.51 \\
4.58 \\
4.54\end{array}$ & $\begin{array}{l}0.1063 \\
0.0134 \\
-.0265 \\
0.1005 \\
-.0420 \\
0.0541 \\
0.0440 \\
0.0562 \\
0.0155 \\
-.0087\end{array}$ & $\begin{array}{l}1288.45 \\
1212.96 \\
1227.17 \\
1327.83 \\
1236.77 \\
1351.71 \\
1332.40 \\
1333.59 \\
1368.88 \\
1363.52\end{array}$ & $\begin{array}{l}1212.96 \\
1227.17 \\
1327.83 \\
1236.77 \\
1351.71 \\
1332.40 \\
1333.59 \\
1368.88 \\
1363.52 \\
1407.81\end{array}$ & $\begin{array}{l}-.0586 \\
.0 .0117 \\
0.0820 \\
-.0686 \\
0.0929 \\
-.0143 \\
0.0009 \\
0.0265 \\
-.0039 \\
0.0325\end{array}$ & $\begin{array}{l}43.36 \\
43.21 \\
43.08 \\
42.72 \\
42.13 \\
42.00 \\
42.57 \\
38.96 \\
44.09 \\
46.46\end{array}$ & $\begin{array}{l}43.21 \\
43.08 \\
42.72 \\
42.13 \\
42.00 \\
42.57 \\
39.96 \\
44.09 \\
46.46 \\
43.58\end{array}$ & $\begin{array}{l}-.0035 \\
-.0030 \\
-.0084 \\
-.0138 \\
-.0031 \\
0.0136 \\
-.0848 \\
0.1317 \\
0.0538 \\
-.0620\end{array}$ & $\begin{array}{r}6.8198 \\
7.0997 \\
7.5392 \\
7.8949 \\
8.0834 \\
9.0238 \\
9.0524 \\
9.6204 \\
10.4721 \\
11.7887\end{array}$ \\
\hline U.S. & $\begin{array}{l}1966 \\
1967 \\
1968 \\
1969 \\
1970 \\
1971 \\
1972 \\
1973 \\
1974 \\
1975\end{array}$ & $\begin{array}{l}4.30 \\
4.53 \\
4.61 \\
4.79 \\
4.87 \\
4.79 \\
4.88 \\
5.11 \\
5.35 \\
5.23\end{array}$ & $\begin{array}{l}4.53 \\
4.61 \\
4.79 \\
4.87 \\
4.79 \\
4.88 \\
5.11 \\
5.35 \\
5.23 \\
5.10\end{array}$ & $\begin{array}{l}0.0535 \\
0.0177 \\
0.0390 \\
0.0167 \\
-.0164 \\
0.0186 \\
0.0471 \\
0.0470 \\
-.0224 \\
-.0249\end{array}$ & $\begin{array}{l}1331.19 \\
1307.66 \\
1312.82 \\
1329.44 \\
1357.23 \\
1428.29 \\
1443.35 \\
1450.97 \\
1436.29 \\
1429.70\end{array}$ & $\begin{array}{l}1307.46 \\
1312.82 \\
1329.44 \\
1357.23 \\
1428.29 \\
1443.35 \\
1450.97 \\
1435.29 \\
1429.70 \\
1483.46\end{array}$ & $\begin{array}{l}-.0177 \\
0.0039 \\
0.0127 \\
0.0209 \\
0.0524 \\
0.0105 \\
0.0053 \\
-.0101 \\
-.0046 \\
0.0376\end{array}$ & $\begin{array}{l}42.31 \\
42.11 \\
41.86 \\
41.07 \\
39.83 \\
38.40 \\
38.73 \\
37.51 \\
37.06 \\
45.59\end{array}$ & $\begin{array}{l}42.11 \\
41.86 \\
41.07 \\
39.83 \\
38.40 \\
38.73 \\
37.51 \\
37.05 \\
45.59 \\
45.02\end{array}$ & $\begin{array}{l}-.0047 \\
-.0059 \\
-.0189 \\
-.0302 \\
-.0359 \\
0.0086 \\
-.0315 \\
-.0120 \\
0.0302 \\
-.0125\end{array}$ & $\begin{array}{r}94.1926 \\
99.9580 \\
101.0391 \\
105.0966 \\
108.4073 \\
113.1654 \\
118.5059 \\
125.4209 \\
129.9431 \\
141.1180\end{array}$ \\
\hline
\end{tabular}


TABLE II. 2

CONSUMER PRICE INDECES FOR VARIOUS COUNTRIES

\begin{tabular}{|c|c|c|c|c|c|c|c|c|c|c|c|}
\hline YEAR & 1965 & 1966 & 1967 & 1968 & 1969 & 1970 & 1971 & 1972 & 1973 & 1974 & 1975 \\
\hline AUSTRIA & 85.1 & 87.0 & 90.4 & 93.0 & 95.8 & 100.0 & 104.7 & 111.3 & 119.7 & 131.1 & 142.2 \\
\hline BELGIUM & 84.2 & 87.8 & 90.3 & 92.8 & 96.2 & 100.0 & 104.3 & 110.0 & 117.7 & 132.6 & 149.5 \\
\hline DENMARK & 73.2 & 78.1 & 83.5 & 90.7 & 94.5 & 100.0 & 105.8 & 112.8 & 123.3 & 142.2 & 155.8 \\
\hline FRANCE & 81.0 & 83.2 & 85.4 & 89.3 & 95.0 & 100.0 & 105.3 & 111.7 & 119.9 & 136.3 & 152.2 \\
\hline GERMANY & 88.1 & 91.2 & 92.5 & 94.9 & 96.7 & 100.0 & 105.3 & 111.1 & 118.8 & 127.1 & 134.7 \\
\hline IRELAND & 77.3 & 79.6 & 82.1 & 86.0 & 92.4 & 100.0 & 108.9 & 118.4 & 131.8 & 154.2 & 186.4 \\
\hline ITALY & 86.3 & 88.3 & 91.6 & 92.8 & 95.2 & 100.0 & 104.8 & 110.8 & 122.8 & 146.3 & 171.1 \\
\hline LUXEMBOURG & 86.2 & 89.1 & 91.0 & 93.4 & 95.6 & 100.0 & 104.7 & 110.1 & 116.8 & 128.0 & 141.7 \\
\hline NETHERLANDS & 79.2 & 83.7 & 86.6 & 89.8 & 96.5 & 100.0 & 107.5 & 115.9 & 125.2 & 137.2 & 151.2 \\
\hline NORWAY & 79.0 & 81.0 & 85.0 & 88.0 & 90.0 & 100.0 & 106.0 & 114.0 & 122.0 & 134.0 & 150.0 \\
\hline PORTUGAL & 73.5 & 77.2 & 81.4 & 86.4 & 94.0 & 100.0 & 111.9 & 123.9 & 139.9 & 175.0 & 201.7 \\
\hline SPAIN & 78.1 & 82.9 & 88.3 & 92.6 & 94.6 & 100.0 & 108.3 & 117.2 & 130.6 & 151.1 & 176.7 \\
\hline SWEDEN & 80.0 & 86.0 & 89.0 & 91.0 & 93.0 & 100.0 & 107.0 & 114.0 & 121.0 & 134.0 & 147.0 \\
\hline SWITZERLAND & 84.4 & 88.4 & 91.9 & 94.1 & 96.5 & 100.0 & 106.6 & 113.7 & 123.6 & 135.7 & 144.8 \\
\hline U.K. & 80.0 & 83.1 & 85.2 & 89.2 & 94.0 & 100.0 & 109.4 & 117.2 & 128.0 & 148.4 & 184.4 \\
\hline CANADA & 82.8 & 85.9 & 89.0 & 92.6 & 96.8 & 100.0 & 102.9 & 107.8 & 116.0 & 128.6 & 142.5 \\
\hline U.S. & 81.3 & 83.6 & 86.0 & 89.6 & 94.4 & 100.0 & 104.3 & 107.7 & 114.4 & 127.0 & 138.6 \\
\hline JAPAN & 76.7 & 80.6 & 83.8 & 88.3 & 92.9 & 100.0 & 106.1 & 110.9 & 123.9 & 154.2 & 172.4 \\
\hline
\end{tabular}


for the years $1966-1970$ was absent and this researcher was told on a phone conversation with the U.S. Bureau of Mines official in charge of publishing the data that these specific prices were not at all available. It was his opinion, and mine, that prices did not undergo any appreciable variations during that period. Accordingly, price data was interpolated for the period 1966-1970.

Demand figures were complled from different issues of the OECD Oil statistics and the number of cars from the annual issues of Automobile Facts and Figures. The various data were further compared with those reported by the International Petroleum Annual and the United Nations' Annual Bulletin of Transport statistics.

Figure 2.1 deplcts plots of $G(t), D(t)$, and $P(t)$ versus time for the 15 countries. The following important and interesting observations follow from the figures:

1. In general, when prices were "low", demand Intensity grew almost paralell to the per capita GNP. At the sudden price jump of 1973-1974, demand dipped forming almost a mirror image of the price increase despite the fact that the GNP per capita remained high. These features characterized most of the countries, good examples of which are Norway, the Netherlands, Denmark, Belgium, Germany and Italy.

2. In the specific countries mentioned above, it is 
FIGURE II . I

TIME PLOTS VARIOUS COUNTRIES

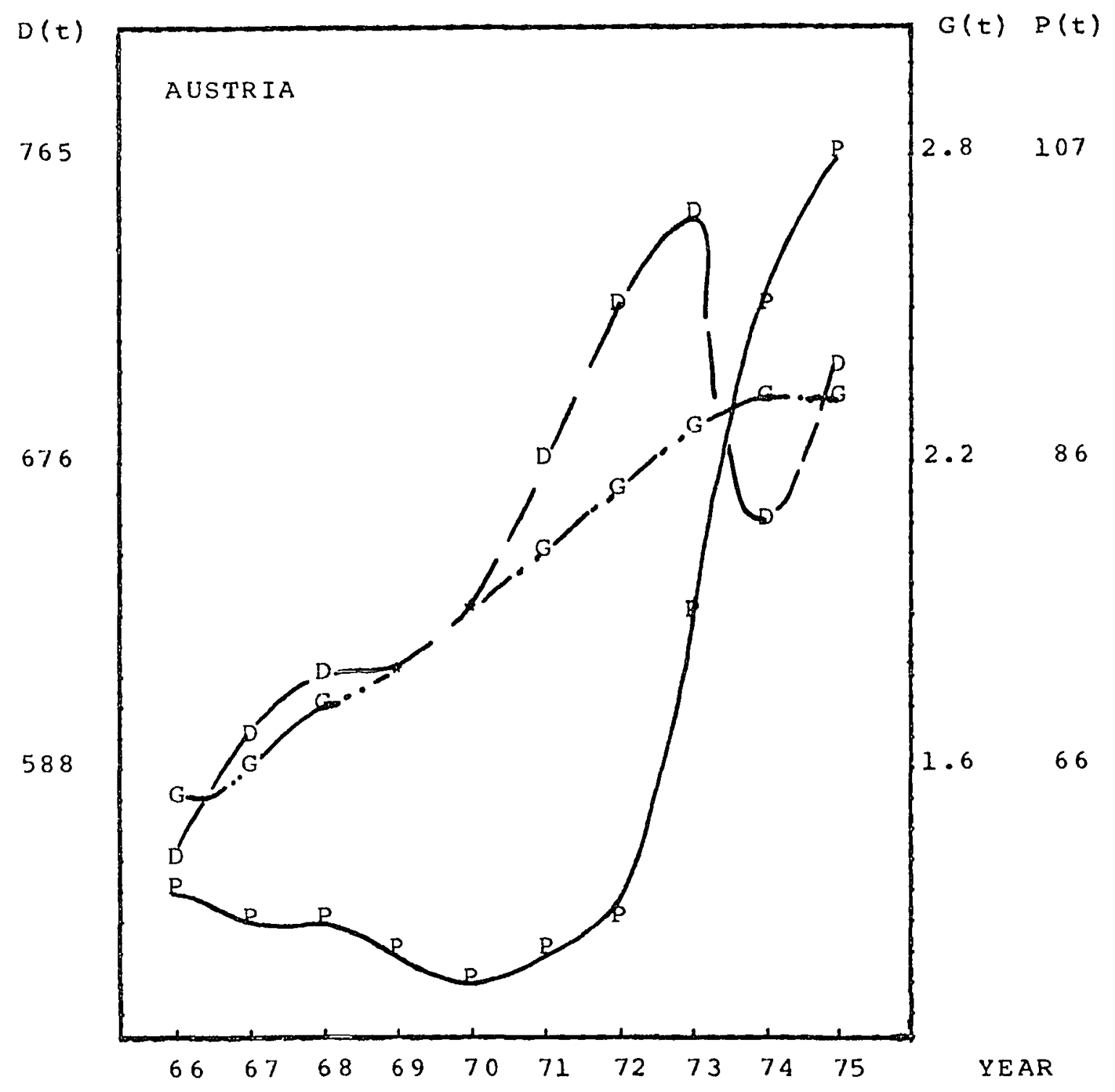


FIGURE II.I CONTD.

TIME PLOTS VARIOUS COUNTRIES

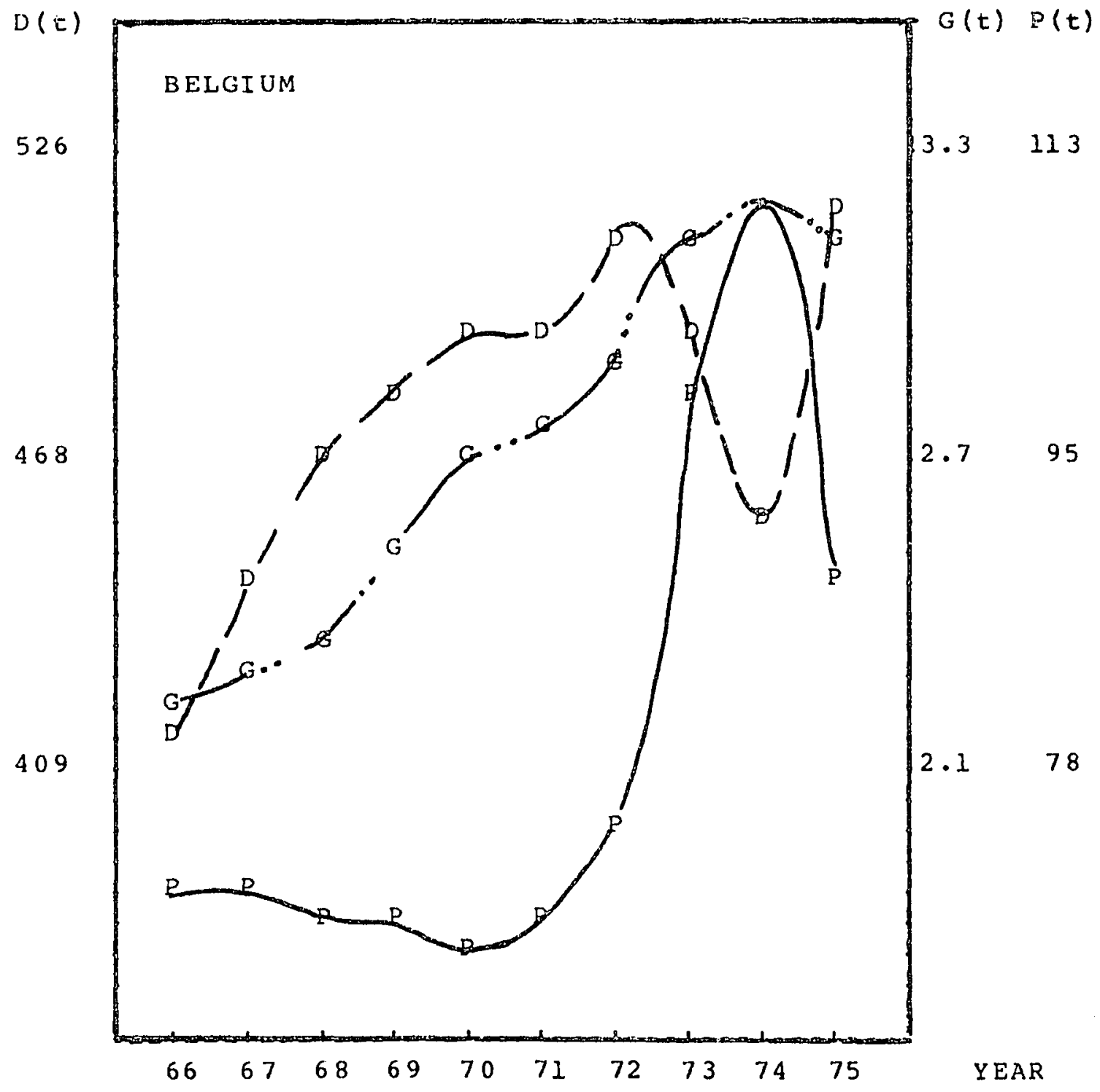


FIGURE II.J. CONTD.

TIME PLO'S VARIOUS COUNTRIES

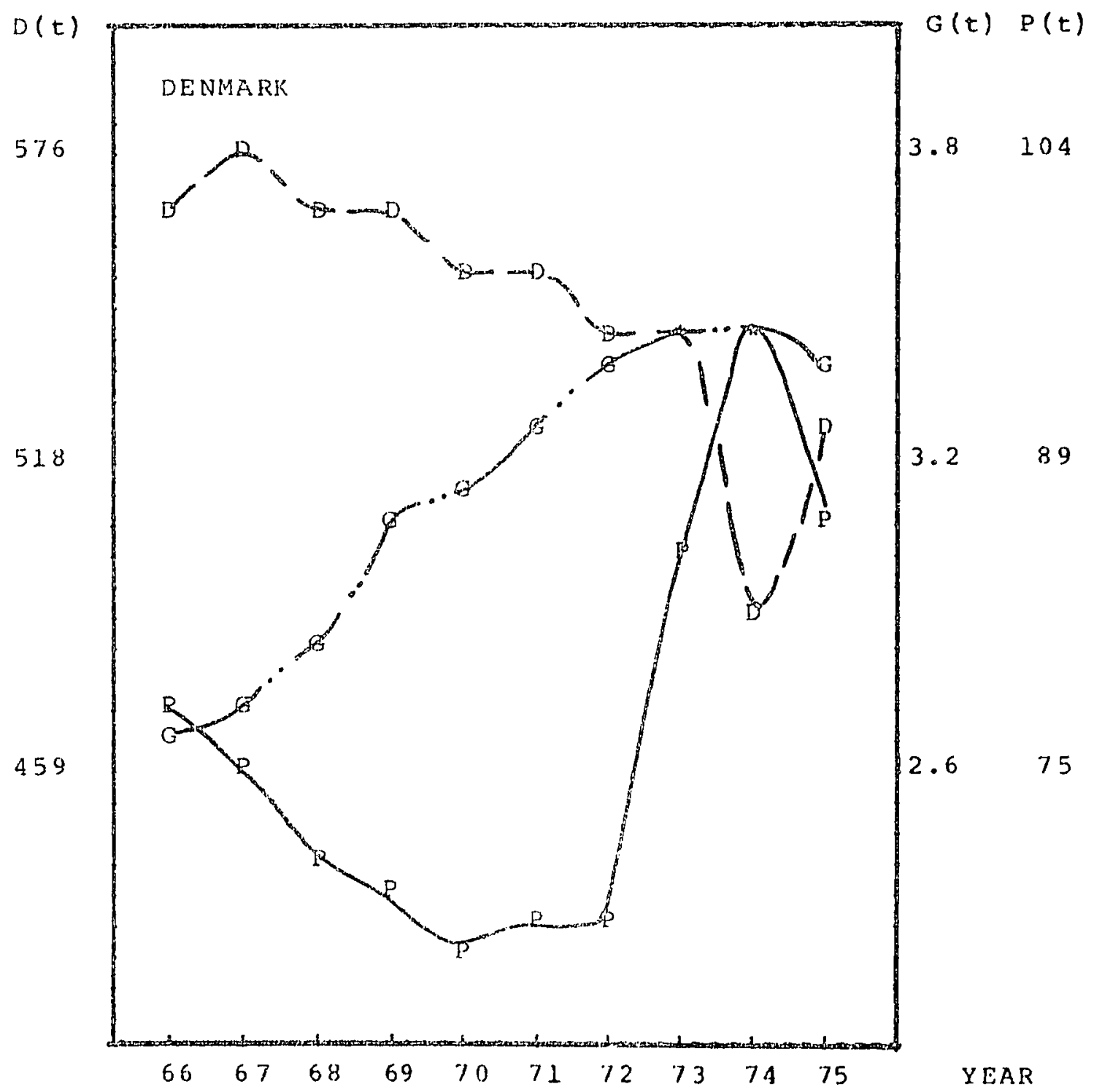




\section{FIGURE II.I CONTD.}

TIME PLOTS VARIOUS COUNTRIES

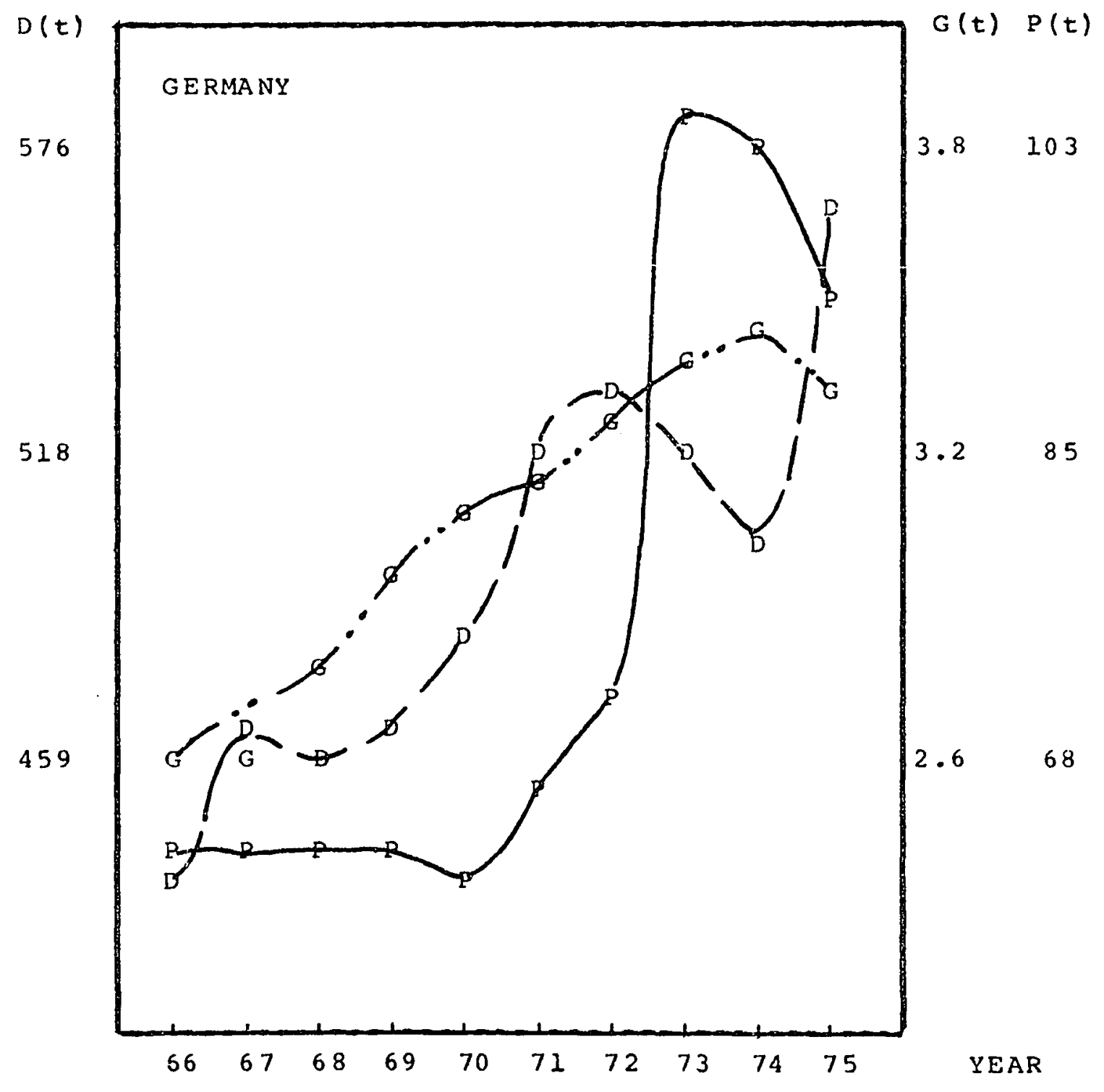




\section{FIGURE II.I CONTD.}

TIME PLOTS VARIOUS COUNTRIES

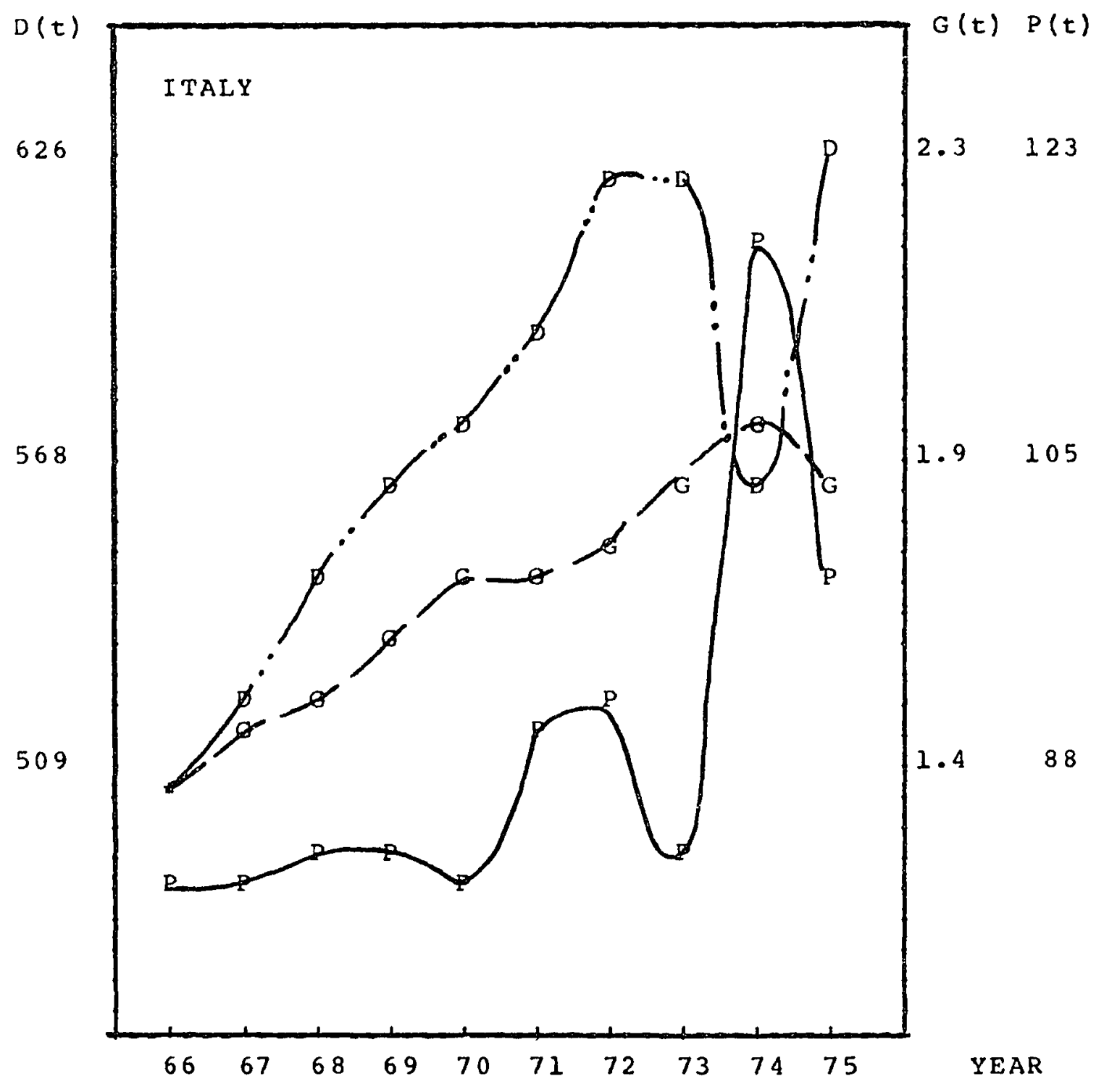




\section{FIGURE II.I CONTD.}

TIME PLOTS VARIOUS COUNTRIES

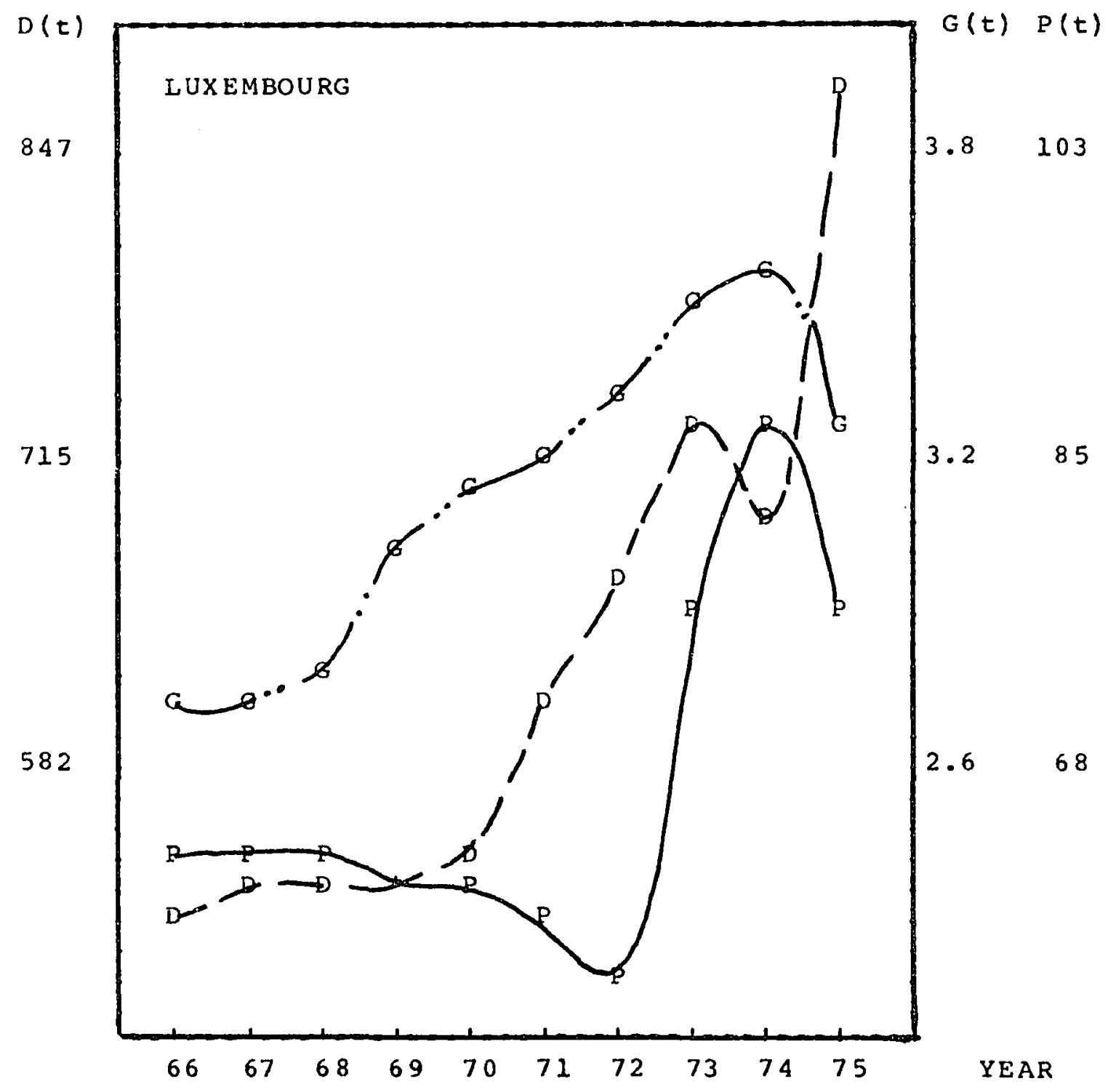


FIGURE II.I CONTD.

TIME PLOTS VARIOUS COUNTRIES

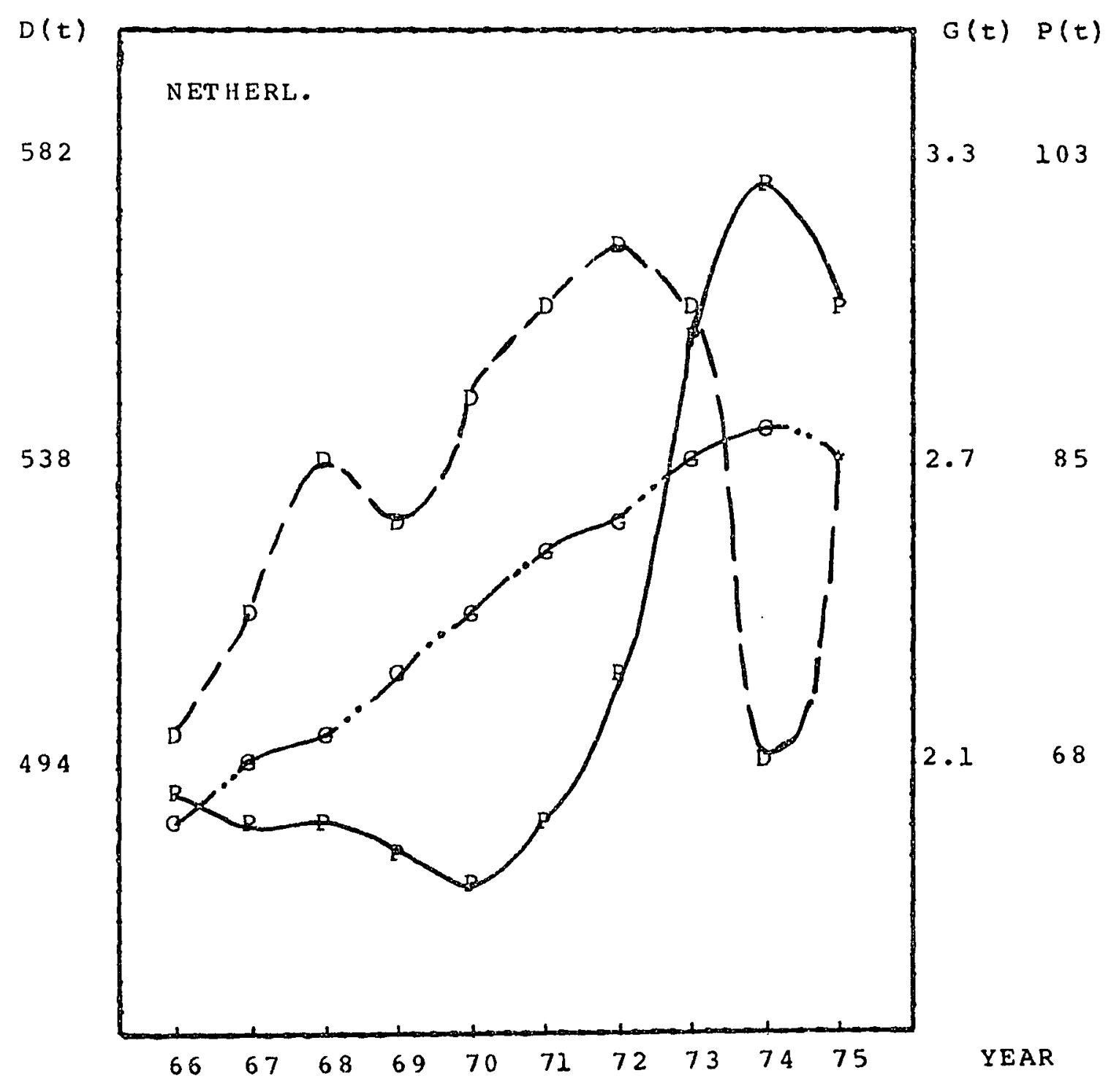


FIGURE II.I CONTD.

TIME PLOTS VARIOUS COUNTRIES

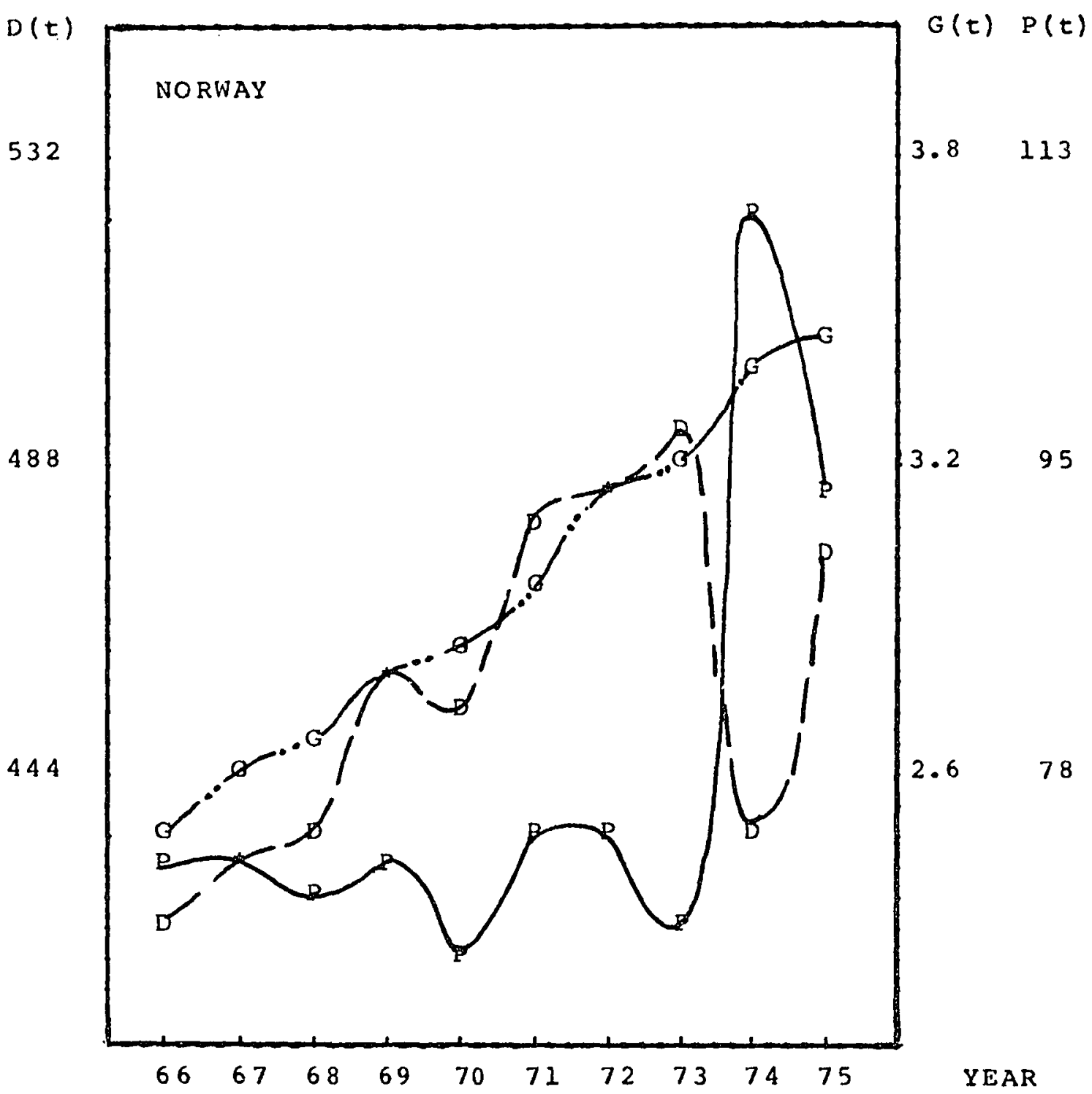


TIME PLOTS VARIOUS COUNTRIES

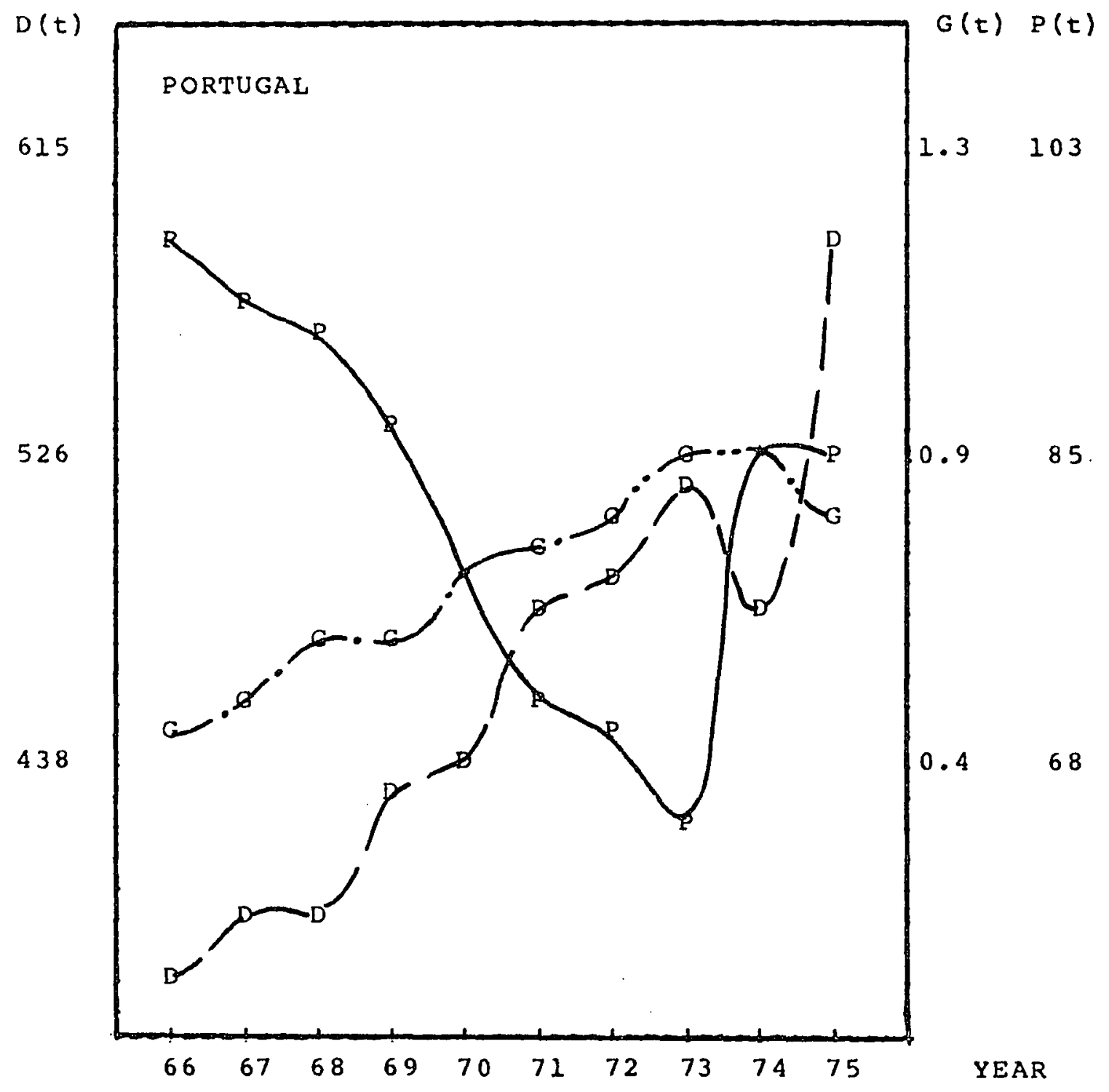


TIME PLOTS VARIOUS COUNTRIES

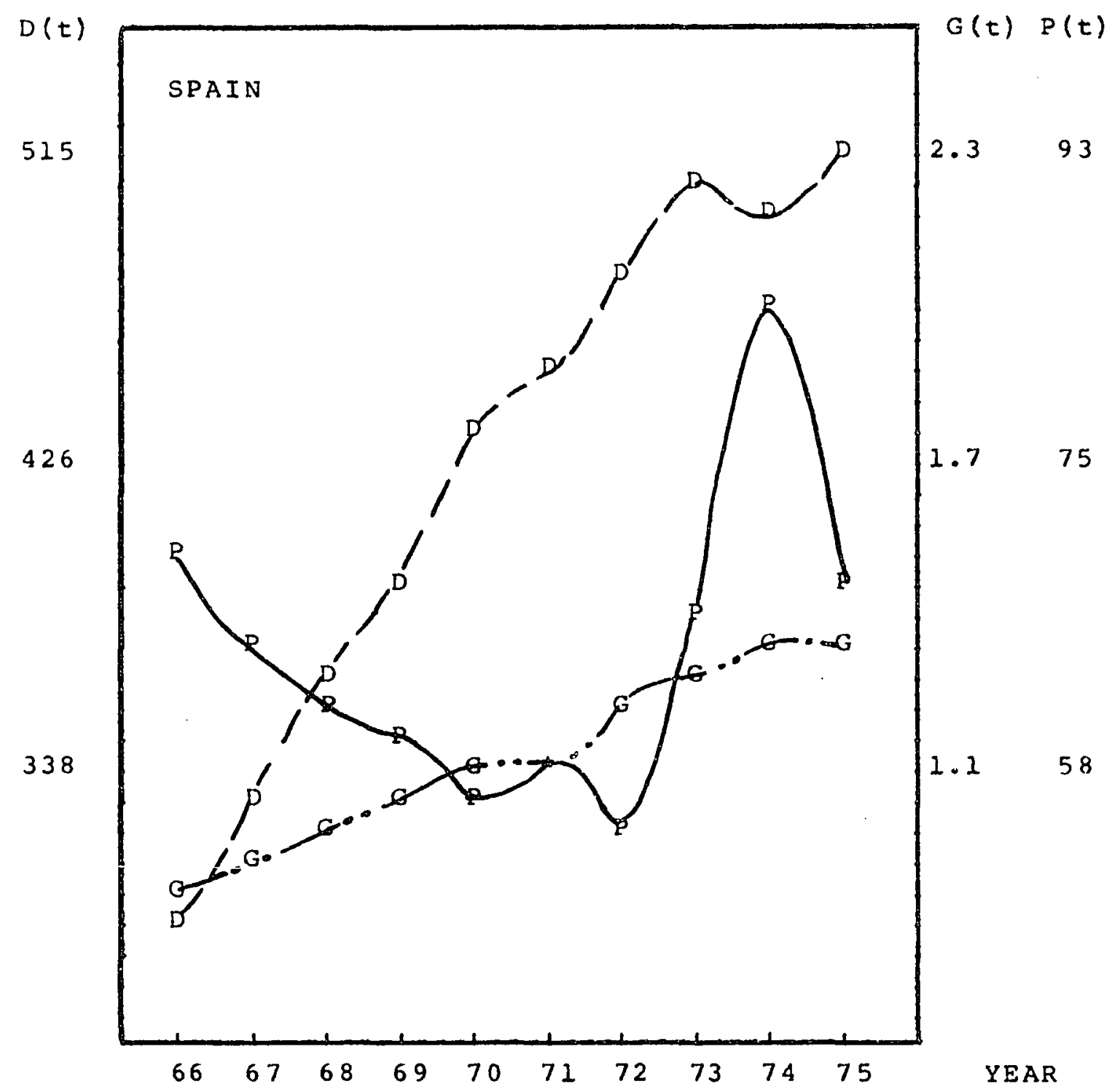


TIME PLOTS VARIOUS COUNTRIES

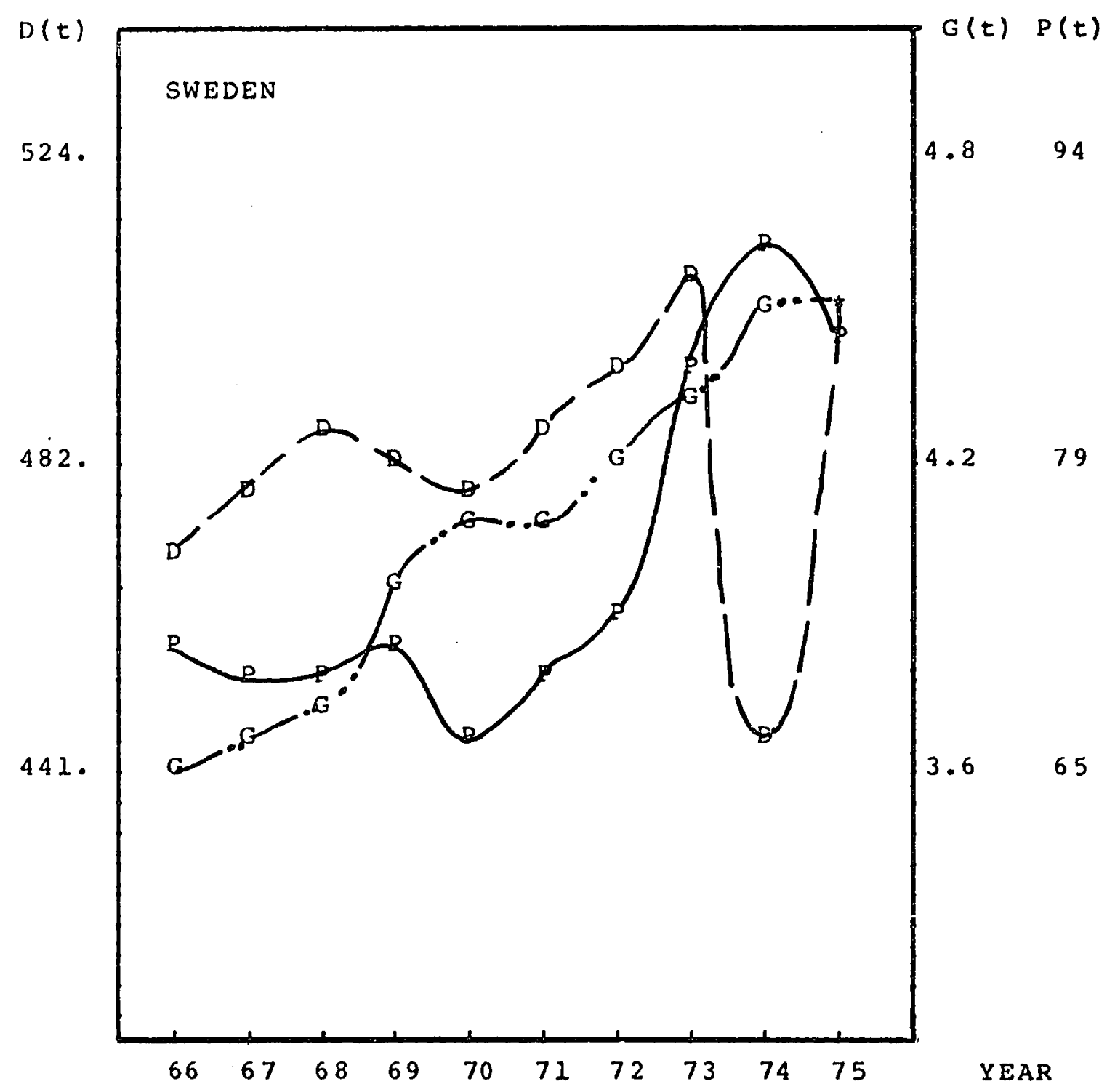


TIME PLOTS VARIOUS COUNTRIES

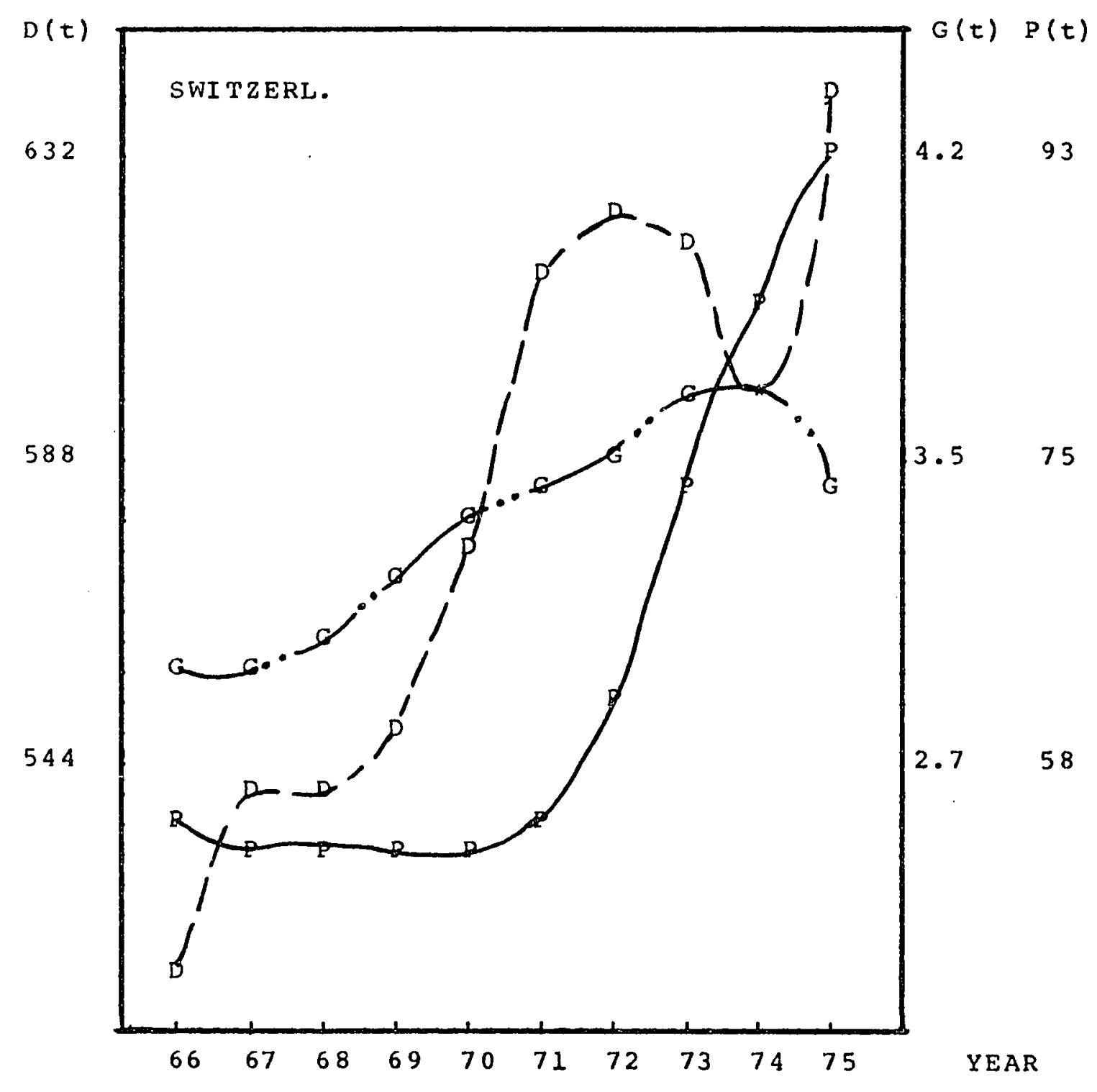




$$
\text { FIGURE II. } 1 \text { CONTD. }
$$

\section{TIME PLOTS VARIOUS COUNTRIES}

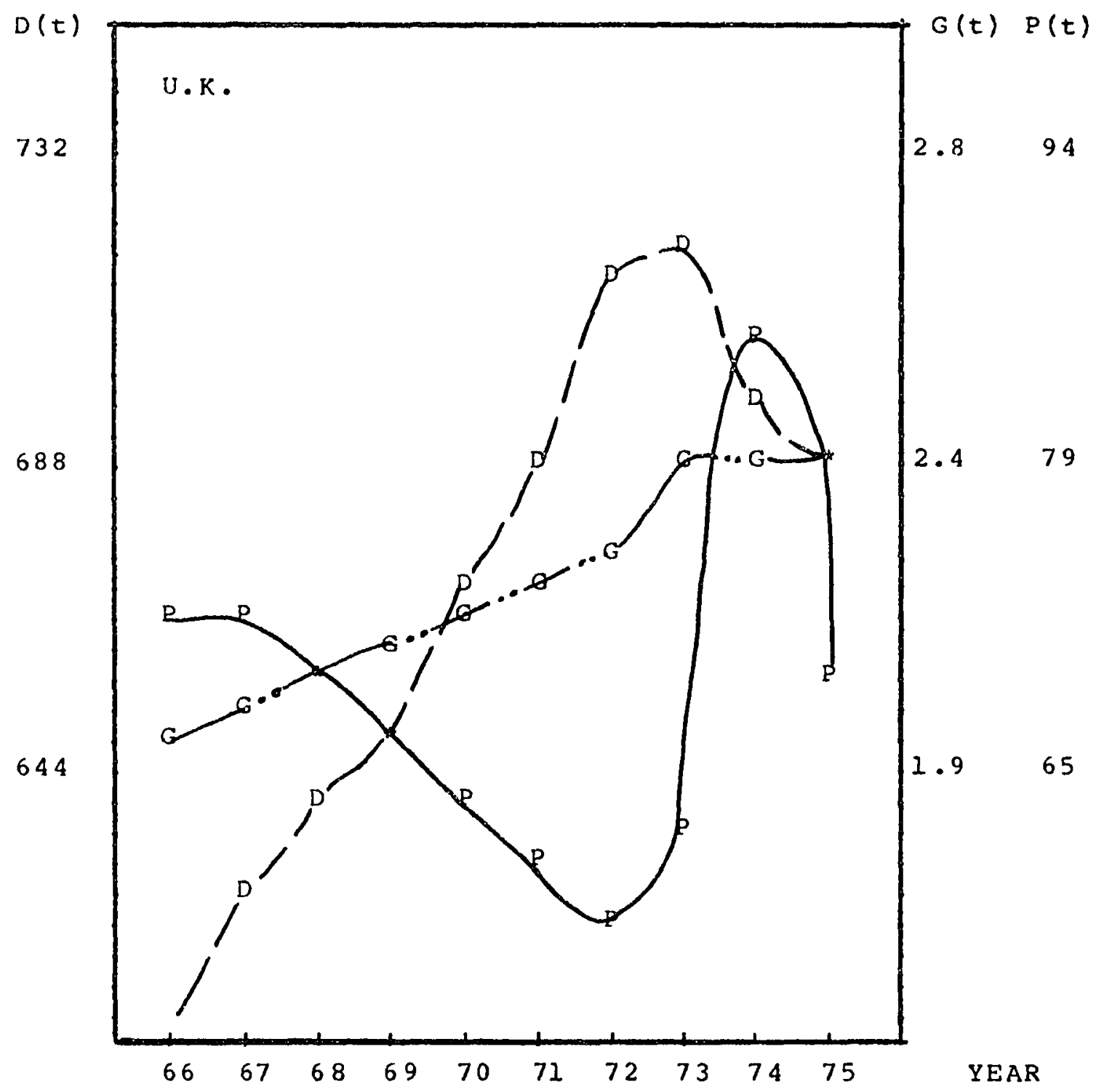


TIME PLOTS VARIOUS COUNTRIES

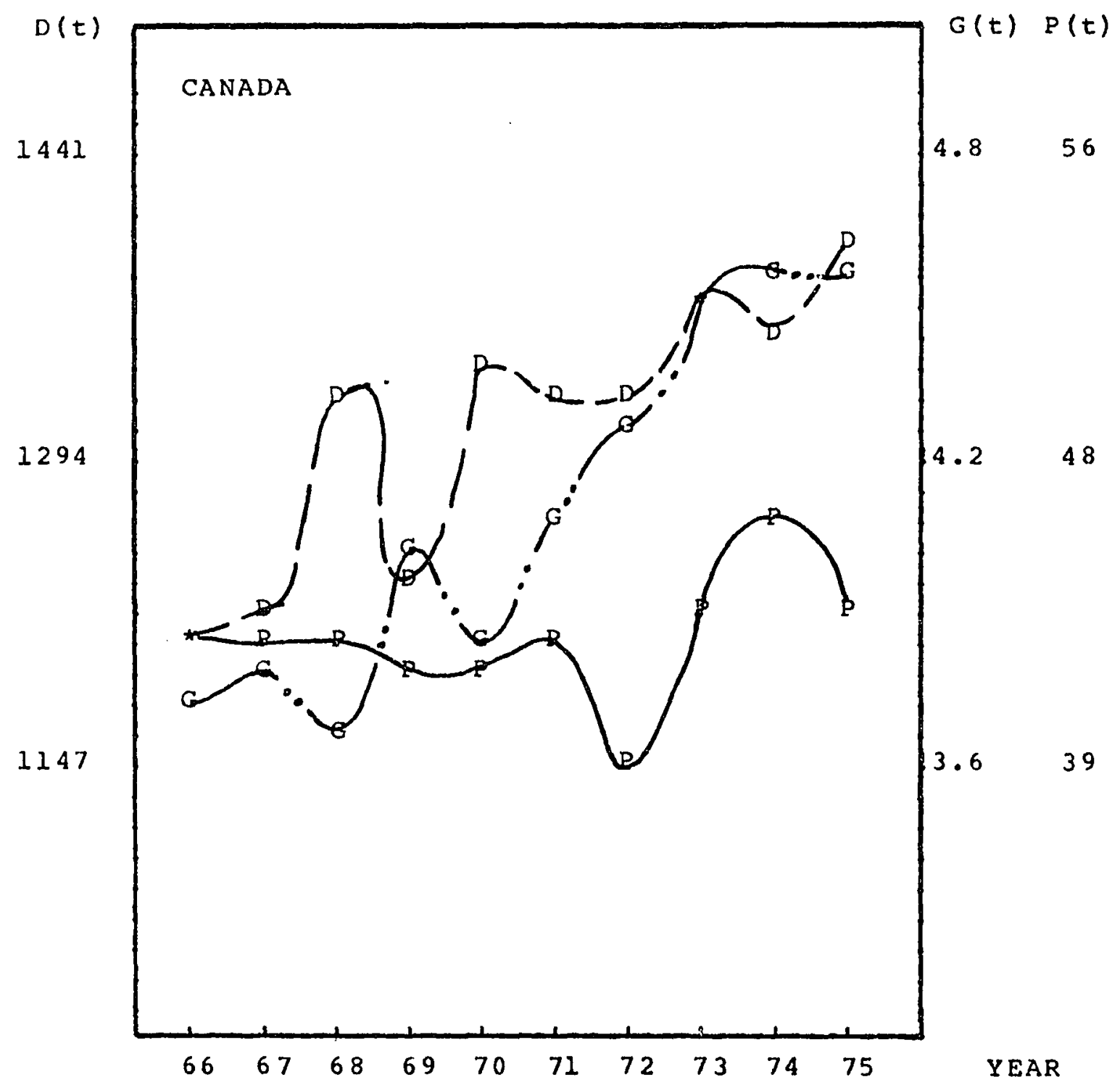




$$
\text { FIUURE II.I CONTD. }
$$

TIME PLOTS VARIOUS COUNTRIES

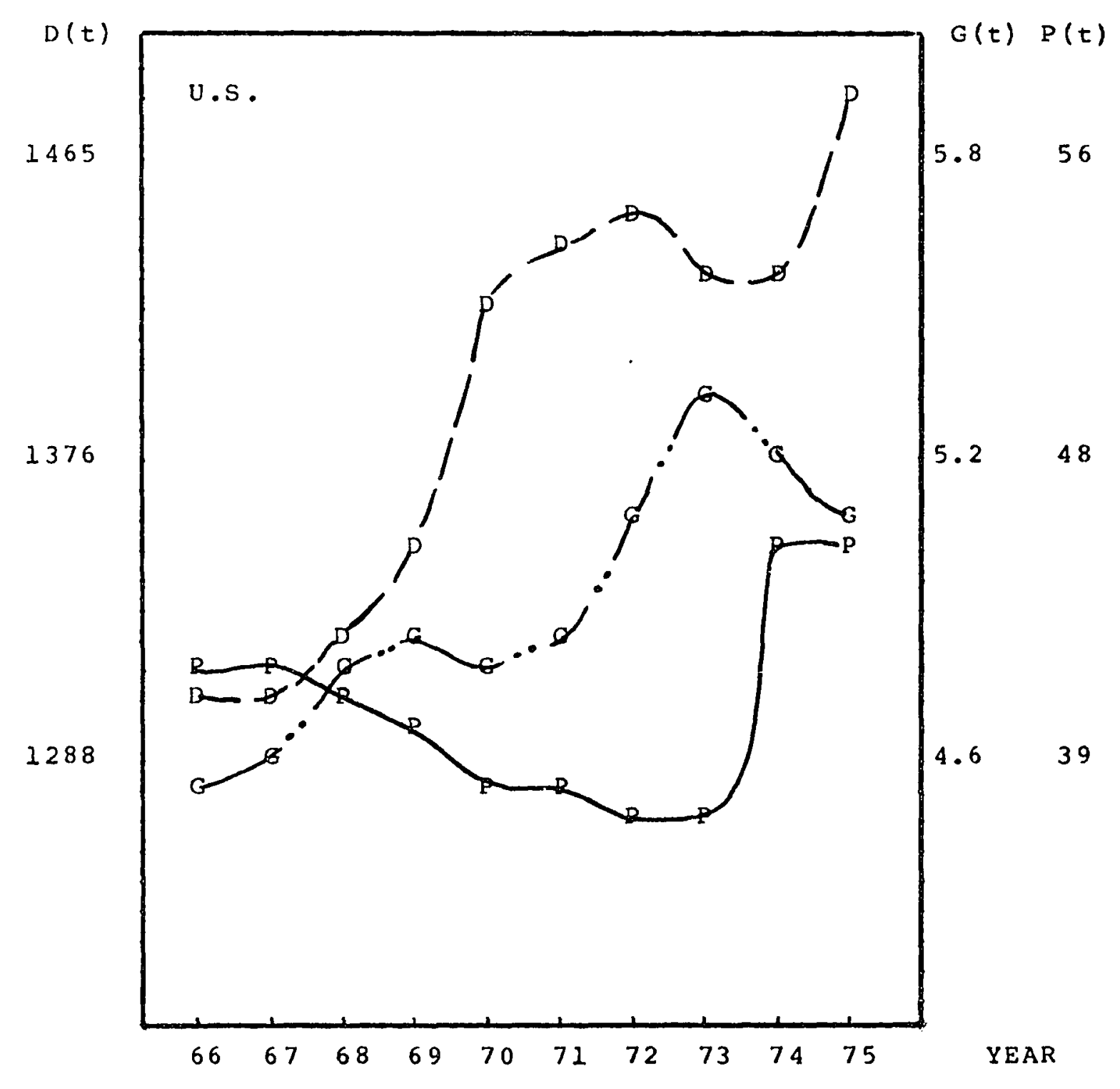


worth noting that $D(t)$ was minimum at maximum $G(t)$ and maximum $P(t)$.

This could be indicative of the predominant price influence at these specific price levels.

3. It might be argued that the substantial reduction in demand Intensity can be attributed to several factors in addition to or other than price increase. Among the possible factors are:

i. The perception of the eminence of the energy crisis that characterized the embargo era.

1i. Conscious efforts to conserve energy in order to meet the political challenge.

iii. Government sponsored regulatory programs, short of rationing, such as imposing speed limits or assigning certain tines for the sale of gasoline, might have inconvenienced the consumers, thus reducing demand.

All the above factors are reasonable and probably had some effect. The problem is to assess how much influence can be attributed to price increase and how much to other factors.

Another difficulty arises from the fact that in almost all of the countries. prices decreased in real terms between 1974 and 1975, while demand increased. This makes it impossible to determine whetiner the 1973-74 demand dip was a temporary 
immediate reaction to the suddenness of the price increase that would have disappeared anyway, or if the decline was price induced.

In an attempt to answer the above questions, cross section data for all countries were considered at different years. The cross sectional demand Intensity did not show the familiar downward sloping demand behavior when price was considered as the independent variable. Using the ratio of current price to current per capita GNP, P.F.. as the explanatory variable brought the behavior closer to the economic demand pattern. Demand per capita was then examined as a function of the price factor P.F. and the resulting pattern was quite rational, from an economic theory stand point.

The cross section analysis discussed above ls explained in chaptex three.

\section{ANALYSIS TECHNIQUE: STEPWISE REGRESSION}

Stepwise regression anlysis is used to test the hypothesized models. A good exposition of the method can be found in Draper and Smith (1966, pp. 171-173) who recommend it as the best of the variable selection procedures. In this method, independent variables are entered sequentially into the model according to their corresponding contribution to the response, measured by the partial F criterion. At each stage, the resulting model is reexamined and any 
variable that provides insignificant contribution is remover from the model.

\section{MULT ICOLL INEAR I TY}

In estimating the model coefficients, the stepwise regression algorithm uses Ordinary Least Squares (OLS) as the method of estimation. One of the basic assumptions of oLs regression, applied to the general linear model, is that no linear dependence exists among the explanatory variables. Such dependence is referred to, in econometrics, as multicollinearity and results in "biasing" the estimates of the model parameters, leading to a drop in the estimation precision (Johnston, 1972, p. 160).

While dropping some independent variables which appear as highly correlated with the rest might seem as a cure to the problem, it should be noted that the omlssion of a variable which belongs to the "correct" equation (which is unfortunately not known a prioril can be the source of a different kind of bias (Christ, 1966, p. 388). Multicolinearity can also lead to a distortion of the statistical significance of the estimates, leading the investigator to drop variables incorrectly from the analysis, thus causing the problems described above.

The most efficient cure to multicollinearity is to work with large data sets, hence, having substantially high degrees of freedom (the covariances among the estimated parameters are inversely proportional to the sample size). 
Unfortunately, short span is almost a characteristic of time series data, and causes a major problem to researchers (Houthaker, 1966, p. 6), with the possible exception of archeologists. Trying to extend their data base, investigators resort to cross-section data to make up for the short time series (stone, 1954), yet facing the problems of interpretation and specification (Meyer, 1957,pp. $380-393)$

Christ (1966, p. 389), a highly distinguished econometrician, states that multicollinearity is no disadvantage in predictive models if the joint distribution of the explanatory variables remains unchanged in the forecast period.

In view of the above difficulties and uncertalinties, a priori theory coupled with subjective judgement is unavoidable in such an analysis, and in modeli ing in general, for that matter (Christ, 1962, p. 389; Shannon, 1975, pp. 211-212; Plog, 1974, pp. 150-1531.

MULTICOLLINEARITY IN THE PRESENT MODEL

In order to investigate the existence of multicollinearity among the explanatory variables employed in the present research, a principal component analysis was performed on the time series data of the fifteen OECD countries.

Table II.3 depicts a computer print out of the analysis conducted for Austria. The table displays the correlation 
coefficients matrix, the eigenvalues, the cumulative proportion of total variance and the eigenvectors of the principal components. The correspondence of the variables to the variabie numbers given in the table is as follows, in an ascending order: $G(t-1), G(t), g(t), D(t-1), d(t)$, $P(t-1), P(t), p(t)$ and $N(t)$.

The following observations can be made about table I. 3 :

1. The correlation coefficients matrix shows an extremely strong correlations between both the current and the lagged GNP per capita on the one hand and the number of cars on the other.

2. As may be expected, the current values of the per capita GNP and the price variables are strongly correlated with their corresponding lagged values. It is well known that the introduction of lagged variables presents a dynamic element in the model at the expense of introducing serial correlations.

3. The eigenvalues together with the values of the cumulative proportion of total variance indicate that the almensionality of the system is at most equal to 4. The latter values show that all the variance in the system is accounted for by only four principal components, the first three of which account for 958 of the variance. 
TABLE II. 3

PRINCIPAL COMPONENT ANALYSIS FOR AUSTRIA

CORRELATIUN COFFFICIFNT MATRIX

\begin{tabular}{|c|c|c|c|c|c|c|c|c|c|}
\hline & 1 & 2 & 3 & $a$ & 5 & 6 & 7 & 8 & \\
\hline $\begin{array}{l}1 \\
2 \\
3 \\
4 \\
5 \\
6 \\
7 \\
8 \\
9\end{array}$ & $\begin{array}{r}1.0000 \\
.9827 \\
.03017 \\
.8578 \\
.66792 \\
.6386 \\
.0112 \\
.7343 \\
.9929\end{array}$ & $\begin{array}{r}.9827 \\
1.0000 \\
.1215 \\
.9233 \\
.6531 \\
.5012 \\
.7141 \\
.7538 \\
.9753\end{array}$ & $\begin{array}{r}. .3017 \\
-.1215 \\
1.1000 \\
.1077 \\
.2412 \\
.08150 \\
. .6715 \\
.01059 \\
. .2919\end{array}$ & $\begin{array}{r}.8578 \\
.9233 \\
.1477 \\
.0000 \\
.06653 \\
.02855 \\
.5654 \\
.7920 \\
.6965\end{array}$ & $\begin{array}{l}-.6792^{-} \\
.6531 \\
.2912 \\
.66553 \\
1.0000 \\
.07305 \\
=.7913 \\
=.4793 \\
.65559\end{array}$ & $\begin{array}{r}.6386 \\
.5012 \\
.6150 \\
.2655 \\
.7305 \\
1.0000 \\
.9190 \\
.3172 \\
.6271\end{array}$ & $\begin{array}{r}.8112 \\
.7141 \\
.66715 \\
.5654 \\
. .7913 \\
.9190 \\
1.0000 \\
.6631 \\
27802\end{array}$ & $\begin{array}{r}.7303 \\
.7538 \\
.1059 \\
.1920 \\
. .0743 \\
.3172 \\
.6631 \\
1.0000 \\
.6852 \\
\end{array}$ & $\begin{array}{r}.9929 \\
.9753 \\
.0019 \\
.8065 \\
.65599 \\
.6271 \\
.7802 \\
.6852 \\
1.0000\end{array}$ \\
\hline
\end{tabular}

EIGENVALUES

6.1929130

$\begin{array}{ll}1.9252964^{\circ} & .5488470^{-} \\ .0003053 & .0000010\end{array}$

.3904969

.0309693

.0076375

CUmulative PROPORTION RF total VARIANCE
$\therefore .09$
.89
.95

1.00

1.00

1.00

1.00

1.00

Ė ËGENVËCTOŔ̉

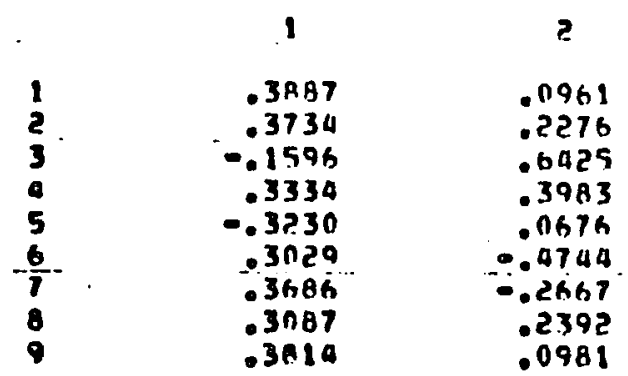

$\begin{array}{cc}3 & . \\ .1386 & .3008 \\ .0911 & .2927 \\ .03771 & 0.0242 \\ . .1028 & 0.0291 \\ .7641 & .0250 \\ . .1739 & .0503 \\ .0061 & -.02596 \\ .4345 & . .7176 \\ .1293 & .9214\end{array}$

5
.1401
.2169
.5568
.0810
.1119
.2601
.2488
.1313
.0149

6
.3613
.0772
. .2687
. .2308
.02559
. .3757
-.0881
.0392
. .5480

7
.0185
.1748
.1613
.0473
.4110
.3302
.3225
.02252
.05571

$\begin{array}{cc}8 & 0 \\ .0216 & .7072 \\ -.0919 & -.6332 \\ .0139 & .1019 \\ .0334 & .0231 \\ -.0134 & .0177 \\ .5991 & -.1761 \\ -.7116 & .0135 \\ .2589 & -.0153 \\ -.1896 & -.0605\end{array}$


4. Lagged demand intensity is strongly correlated with both the lagged and the current GNP per capita and the number of cars.

The above observations indicate strong mulicollinearity among some of the explanatory variables and may suggest the use of the principal components as explanatory variables instead. This behavior was typical for all other countries.

While regression on the principal components might be useful for purely predictive purposes, it makes any economic or behavioral interpretation of the results linpossible. For example, the demand elasticity with respect to any of the principal components would be economically and behaviorally meaningless measure. The reason is obviously the fact that each principal component is a weighted linear combination of all the explanatory variables.

Based on the above analysis, the original explanatory variables of the model were retained and several modifications of the linear model were formulated by separating current from lagged variables and experimenting on the resulting versions by adding or deleting highly correlated variables. Analysis of the resulting formulations served in assessing the effects of multicollinearity. The research methodology is explained in the remainder of this chapter and in chapter III.

It should be pointed out that ridge regression analysis 
which generates deliberately biased estimators is another good technique for use in situations, like the present model, where the number of variables is large. A good exposition of the ridge regression approach is given in the book edited by Thompson and Foster (1973, pp. 68-123).

\section{RESEARCH METHODOLOGY}

The following methodology was followed in the current research:

1. Four different models were hypothesized.

2. Time series data for 15 different countries of the $O E C D$ were fitted to the models using stepwise regression analysis.

3. Based on the regression results, the first model was found satisfactory and was further analyzed.

4. Price- and GNP-elasticities of demand were calculated for each country for the various years.

5. The ratio of motor gasoline price in U.S. cents per galion to the GNP per capita in thousand dollars (P.F.) was suggested as a possible causal influence behind the variability of demand elasticities among various countries. The range of $P . F$. was subdivided into intervals of 5 units each and average demand elastlcities corresponding to each 
interval were calculated.

6. Average elasticities were fitted for different functional forms of the variable $P . F$. and a best least squares fit was chosen.

7. In order to assess the sensicivity of the results to multicollinearity, two versions of the linear model were considered further. In the first version all lagged variables were removed: in the second version, all current variables were dropped and the lagged included.

8. Steps 2 and 4 through 6 were repeated for each of the two vergions described in 7 above, once with $N(t)$ included and once without it.

9. Cross sectional data of the fifteen OECD countries were further analyzed in order to gain more insight into the variability of demand over countries.

10. The results of all the previous steps were analyzed, compared and concluded in the form of viable limiting ranges for the various elasticity measures as functions of P.F.

11. The estimated elasticity functions were used to retrospectively forecast demand levels in France, Ireland and Japan. The resulting forecasts showed acceptable accuracy. 
12. Finally, two simulation runs were performed. The first run was exploratory; assuming different growth rates in per capita GNP and price levels, scenarios of likely demand behavior were generated. The second simulation was normative demonstrating the use of the research findings as a policy tool. Starting with a specific demand policy; President Carter's energy proposal was used; and assuming that price is the policy control mechanism, a price profile till the year 1990 was generated, which would achieve the consumption goals. 
CHAPTER III

TIME SERIES ANALYSIS

Tables III.l through III.4 display the time series regression results of models I through IV, in two rows for each country. The first row gives the regression estimates of the model parameters and the square of the multiple correlation coefficient (R-SQR.) . The second row contains the F-values associated with these estimates.

As mentioned in chapter II, nine possible explanatory variables were assumed in each model. The stepwise regression algorithm was then used to find those variables with the highest correlative association with demand. It should be pointed out that $d(t)$ was defined in terms of $D(t-$ 1) and $D(t)$, and the same is true for $g(t)$ and $p(t)$. Therefore, any one of these triplets (e.g. $D(t-1), D(t)$ and $a(t))$ is completely collinear.

For the above reason, and in order to improve the precision of the estinates by reducing multicollinearity, the following steps were followed:

1. $d(t)$ was excluded from runs where $D(t)$ was the dependent variable, and vice versa.

2. In choosing the "best" regression equation, the choice was made among models which did not have the 
TABLE III.1

REGRESSION COEFFICIENTS FOR MODEL I

\begin{tabular}{|c|c|c|c|c|c|c|c|c|c|c|c|c|}
\hline & & $a(0)$ & $a(1)$ & $\theta(2)$ & $a(3)$ & $a(4)$ & $a(5)$ & $a(6)$ & $\theta(7)$ & $a(8)$ & $8(9)$ & R-SQR \\
\hline AUSTRIA & & $\begin{array}{r}486.37 \\
0.00\end{array}$ & $\begin{array}{l}0.00 \\
0.00\end{array}$ & $\begin{array}{l}0.00 \\
0.00\end{array}$ & $\begin{array}{l}0.00 \\
0.00\end{array}$ & $\begin{array}{l}0.00 \\
0.00\end{array}$ & $\begin{array}{l}0.00 \\
0.00\end{array}$ & $\begin{array}{l}0.00 \\
0.00\end{array}$ & $\begin{array}{r}-2.13 \\
0.58\end{array}$ & $\begin{array}{r}135.70 \\
72.12\end{array}$ & $\begin{array}{r}211.04 \\
35.55\end{array}$ & 0.92 \\
\hline BELGIUH & & $\begin{array}{r}597.37 \\
0.00\end{array}$ & $\begin{array}{l}0.00 \\
0.00\end{array}$ & $\begin{array}{l}0.00 \\
0.00\end{array}$ & $\begin{array}{r}161.77 \\
69.62\end{array}$ & $\begin{array}{r}-0.48 \\
0.10\end{array}$ & $\begin{array}{l}0.00 \\
0.00\end{array}$ & $\begin{array}{l}0.00 \\
0.00\end{array}$ & $\begin{array}{r}-2.26 \\
0.13\end{array}$ & $\begin{array}{r}137.86 \\
18.04\end{array}$ & $\begin{array}{r}117.21 \\
6.07\end{array}$ & 0.99 \\
\hline DENMARK & & $\begin{array}{r}847.27 \\
0.00\end{array}$ & $\begin{array}{r}-123.41 \\
45.17\end{array}$ & $\begin{array}{l}0.00 \\
0.00\end{array}$ & $\begin{array}{l}0.00 \\
0.00\end{array}$ & $\begin{array}{l}0.00 \\
0.00\end{array}$ & $\begin{array}{l}0.00 \\
0.00\end{array}$ & $\begin{array}{l}0.00 \\
0.00\end{array}$ & $\begin{array}{r}-1.19 \\
0.39\end{array}$ & $\begin{array}{l}68.01 \\
45.98\end{array}$ & $\begin{array}{r}127.54 \\
80.58\end{array}$ & $0 . ?$ \\
\hline GEKMANY & $:$ & $\begin{array}{r}308.05 \\
0.00\end{array}$ & $\begin{array}{l}640.36 \\
289.70\end{array}$ & $\begin{array}{r}-658 \cdot 13 \\
262.82\end{array}$ & $\begin{array}{r}1410.91 \\
738.81\end{array}$ & $\begin{array}{l}0.24 \\
0.08\end{array}$ & $\begin{array}{l}0.00 \\
0.00\end{array}$ & $\begin{array}{l}0.00 \\
0.00\end{array}$ & $\begin{array}{r}-1.40 \\
0.14\end{array}$ & $\begin{array}{l}94.17 \\
17.90\end{array}$ & $\begin{array}{r}15.12 \\
3.14\end{array}$ & 0.99 \\
\hline ITALY & i & $\begin{array}{r}508.64 \\
0.00\end{array}$ & $\begin{array}{r}-232.19 \\
163.11\end{array}$ & $\begin{array}{l}0.00 \\
0.00\end{array}$ & $\begin{array}{r}-1095.53 \\
390.89\end{array}$ & $\begin{array}{l}1.03 \\
0.37\end{array}$ & $\begin{array}{l}0.00 \\
0.00\end{array}$ & $\begin{array}{l}0.00 \\
0.00\end{array}$ & $\begin{array}{r}-2.49 \\
0.39\end{array}$ & $\begin{array}{l}0.00 \\
0.00\end{array}$ & $\begin{array}{r}10.99 \\
6.86\end{array}$ & 0.98 \\
\hline LUXEMHOURG & & $\begin{array}{r}104.39 \\
0.00\end{array}$ & $\begin{array}{r}3239.06 \\
155.83\end{array}$ & $\begin{array}{r}-3137.29 \\
156.30\end{array}$ & $\begin{array}{r}8447.60 \\
492.12\end{array}$ & $\begin{array}{l}1.28 \\
0.09\end{array}$ & $\begin{array}{l}0.00 \\
0.00\end{array}$ & $\begin{array}{l}0.00 \\
0.00\end{array}$ & $\begin{array}{r}-8.20 \\
0.44\end{array}$ & $\begin{array}{r}483.97 \\
24.09\end{array}$ & $\begin{array}{r}-21.51 \\
6.77\end{array}$ & 0.99 \\
\hline NETHERL. & & $\begin{array}{r}991.83 \\
0.00\end{array}$ & $\begin{array}{r}-44.26 \\
44.34\end{array}$ & $\begin{array}{r}-207.08 \\
42.33\end{array}$ & $\begin{array}{l}0.00 \\
0.00\end{array}$ & $\begin{array}{l}0.00 \\
0.00\end{array}$ & $\begin{array}{l}0.00 \\
0.00\end{array}$ & $\begin{array}{l}0.00 \\
0.00\end{array}$ & $\begin{array}{r}-3.19 \\
0.19\end{array}$ & $\begin{array}{r}311.46 \\
26.43\end{array}$ & $\begin{array}{r}128.87 \\
11.75\end{array}$ & 0.99 \\
\hline NORWAY & & $\begin{array}{r}508.93 \\
0.00\end{array}$ & $\begin{array}{l}0.00 \\
0.00\end{array}$ & $\begin{array}{l}97.05 \\
21.78\end{array}$ & $\begin{array}{r}1372.27 \\
226.17\end{array}$ & $\begin{array}{r}-0.64 \\
0.12\end{array}$ & $\begin{array}{l}0.00 \\
0.00\end{array}$ & $\begin{array}{l}0.00 \\
0.00\end{array}$ & $\begin{array}{r}-3.15 \\
0.33\end{array}$ & $\begin{array}{l}69.79 \\
18.87\end{array}$ & $\begin{array}{r}155.50 \\
35.51\end{array}$ & 0.99 \\
\hline
\end{tabular}


TABLE III.1 CONTD.

REGRESSION COEFFICIENTS FOR MODEL I

\begin{tabular}{|c|c|c|c|c|c|c|c|c|c|c|c|}
\hline & $8(0)$ & $a(1)$ & $a(2)$ & $a(3)$ & $a(4)$ & $a(5)$ & $8(6)$ & $a(7)$ & $a(8)$ & $a(9)$ & R-SQR \\
\hline PORTUGAL & $\begin{array}{r}318.44 \\
0.00\end{array}$ & $\begin{array}{l}165.25 \\
135.03\end{array}$ & $\begin{array}{l}0.00 \\
0.00\end{array}$ & $\begin{array}{r}-204.95 \\
104.46\end{array}$ & $\begin{array}{l}0.00 \\
0.00\end{array}$ & $\begin{array}{l}0.00 \\
0.00\end{array}$ & $\begin{array}{r}-0.58 \\
0.84\end{array}$ & $\begin{array}{l}0.00 \\
0.00\end{array}$ & $\begin{array}{r}-248.36 \\
27.65\end{array}$ & $\begin{array}{r}120.26 \\
49.60\end{array}$ & 0.99 \\
\hline SPAIN & $\begin{array}{r}139.81 \\
0.00\end{array}$ & $\begin{array}{l}0.00 \\
0.00\end{array}$ & $\begin{array}{r}290.91 \\
71.69\end{array}$ & $\begin{array}{r}-257.45 \\
76.89\end{array}$ & $\begin{array}{l}0.33 \\
0.15\end{array}$ & $\begin{array}{l}0.00 \\
0.00\end{array}$ & $\begin{array}{l}0.00 \\
0.00\end{array}$ & $\begin{array}{r}-2.44 \\
0.33\end{array}$ & $\begin{array}{l}68.69 \\
18.55\end{array}$ & $\begin{array}{l}0.00 \\
0.00\end{array}$ & 0.89 \\
\hline SWEDEN & $\begin{array}{r}1174.69 \\
0.00\end{array}$ & $\begin{array}{l}0.00 \\
0.00\end{array}$ & $\begin{array}{l}0.00 \\
0.00\end{array}$ & $\begin{array}{l}417.63 \\
141.82\end{array}$ & $\begin{array}{r}-1.35 \\
0.18\end{array}$ & $\begin{array}{l}0.00 \\
0.00\end{array}$ & $\begin{array}{l}0.00 \\
0.00\end{array}$ & $\begin{array}{r}-2.16 \\
0.34\end{array}$ & $\begin{array}{r}320.35 \\
38.32\end{array}$ & $\begin{array}{r}42.29 \\
7.92\end{array}$ & 0.96 \\
\hline SWITZERL. & $\begin{array}{r}22.34 \\
0.00\end{array}$ & $\begin{array}{r}210.15 \\
34.90\end{array}$ & $\begin{array}{l}0.00 \\
0.00\end{array}$ & $\begin{array}{l}0.00 \\
0.00\end{array}$ & $\begin{array}{l}0.00 \\
0.00\end{array}$ & $\begin{array}{l}0.00 \\
0.00\end{array}$ & $\begin{array}{l}0.00 \\
0.00\end{array}$ & $\begin{array}{r}-1.33 \\
0.64\end{array}$ & $\begin{array}{l}0.00 \\
0.00\end{array}$ & $\begin{array}{l}0.00 \\
0.00\end{array}$ & 0.91 \\
\hline $\mathbf{U} \bullet \mathbf{K}$. & $\begin{array}{r}250.35 \\
0.00\end{array}$ & $\begin{array}{l}0.00 \\
0.00\end{array}$ & $\begin{array}{l}0.00 \\
0.00\end{array}$ & $\begin{array}{l}0.00 \\
0.00\end{array}$ & $\begin{array}{l}0.77 \\
0.05\end{array}$ & $\begin{array}{l}0.00 \\
0.00\end{array}$ & $\begin{array}{l}0.00 \\
0.00\end{array}$ & $\begin{array}{r}-1.27 \\
0.28\end{array}$ & $\begin{array}{l}0.00 \\
0.00\end{array}$ & $\begin{array}{l}0.00 \\
0.00\end{array}$ & 0.98 \\
\hline CANADA & $\begin{array}{r}538.81 \\
0.00\end{array}$ & $\begin{array}{l}0.00 \\
0.00\end{array}$ & $\begin{array}{l}0.00 \\
0.00\end{array}$ & $\begin{array}{r}-1321.16 \\
148.46\end{array}$ & $\begin{array}{l}0.98 \\
0.12\end{array}$ & $\begin{array}{l}0.00 \\
0.00\end{array}$ & $\begin{array}{r}-10.82 \\
3.71\end{array}$ & $\begin{array}{l}0.00 \\
0.00\end{array}$ & $\begin{array}{l}0.00 \\
0.00\end{array}$ & $\begin{array}{l}0.00 \\
0.00\end{array}$ & 0.94 \\
\hline U.S. & $\begin{array}{r}161.98 \\
0.00\end{array}$ & $\begin{array}{l}0.00 \\
0.00\end{array}$ & $\begin{array}{l}0.00 \\
0.00\end{array}$ & $\begin{array}{r}-671.61 \\
277.65\end{array}$ & $\begin{array}{l}0.90 \\
0.14\end{array}$ & $\begin{array}{l}0.00 \\
0.00\end{array}$ & $\begin{array}{l}0.00 \\
0.00\end{array}$ & $\begin{array}{l}0.00 \\
0.00\end{array}$ & $\begin{array}{l}0.00 \\
0.00\end{array}$ & $\begin{array}{l}0.00 \\
0.00\end{array}$ & 0.89 \\
\hline
\end{tabular}


TABLE III. 2

REGRESSION COEFFICIENTS FOR MODEL II

\begin{tabular}{|c|c|c|c|c|c|c|c|c|c|c|c|}
\hline & $8(0)$ & $a(1)$ & $\theta(2)$ & $0(3)$ & $a(4)$ & $a(5)$ & $B(6)$ & $a(7)$ & $a(\theta)$ & $a(9)$ & R-SQR \\
\hline AUSTRIA & $\begin{array}{l}0.6470 \\
0.0000\end{array}$ & $\begin{array}{l}0.1998 \\
0.0620\end{array}$ & $\begin{array}{l}0.0000 \\
0.0000\end{array}$ & $\begin{array}{r}-1.4090 \\
0.5680\end{array}$ & $\begin{array}{r}-0.0008 \\
0.0003\end{array}$ & $\begin{array}{l}0.0000 \\
0.0000\end{array}$ & $\begin{array}{l}0.0000 \\
0.0000\end{array}$ & $\begin{array}{r}-0.0066 \\
0.0008\end{array}$ & $\begin{array}{l}0.3900 \\
0.0670\end{array}$ & $\begin{array}{l}0.0000 \\
0.0000\end{array}$ & 0.9800 \\
\hline BELGIUH & $\begin{array}{l}1.3490 \\
0.0000\end{array}$ & $\begin{array}{l}0.0000 \\
0.0000\end{array}$ & $\begin{array}{l}0.0000 \\
0.0000\end{array}$ & $\begin{array}{l}0.4290 \\
0.0001\end{array}$ & $\begin{array}{r}-0.0034 \\
0.0002\end{array}$ & $\begin{array}{l}0.0000 \\
0.0000\end{array}$ & $\begin{array}{l}0.0006 \\
0.0017\end{array}$ & $\begin{array}{r}-0.0053 \\
0.0015\end{array}$ & $\begin{array}{l}0.3620 \\
0.1164\end{array}$ & $\begin{array}{l}0.2579 \\
0.0150\end{array}$ & 0.9900 \\
\hline DENMARK & $\begin{array}{l}2.1214 \\
0.0000\end{array}$ & $\begin{array}{r}-0.1310 \\
0.0290\end{array}$ & $\begin{array}{l}0.0000 \\
0.0000\end{array}$ & $\begin{array}{l}0.0000 \\
0.0000\end{array}$ & $\begin{array}{r}-0.0027 \\
0.0004\end{array}$ & $\begin{array}{l}0.0000 \\
0.0000\end{array}$ & $\begin{array}{l}0.0000 \\
0.0000\end{array}$ & $\begin{array}{r}-0.0033 \\
0.0009\end{array}$ & $\begin{array}{l}0.1439 \\
0.0900\end{array}$ & $\begin{array}{l}0,0000 \\
0: 0000\end{array}$ & C 9100 \\
\hline GERHANY & $\begin{array}{l}0.8390 \\
0.0000\end{array}$ & $\begin{array}{l}0.0000 \\
0.0000\end{array}$ & $\begin{array}{r}-0.1360 \\
0.0510\end{array}$ & $\begin{array}{r}-0.5160 \\
0.1740\end{array}$ & $\begin{array}{r}-0.0018 \\
0.0003\end{array}$ & $\begin{array}{l}0.0000 \\
0.0000\end{array}$ & $\begin{array}{l}0.0000 \\
0.0000\end{array}$ & $\begin{array}{r}-0.0023 \\
0.0004\end{array}$ & $\begin{array}{l}0.1355 \\
0.0323\end{array}$ & $\begin{array}{l}0.0404 \\
0.0000\end{array}$ & 0.9900 \\
\hline ITALY & $\begin{array}{l}0.1760 \\
0.0000\end{array}$ & $\begin{array}{l}0.0000 \\
0.0000\end{array}$ & $\begin{array}{l}0.0000 \\
0.0000\end{array}$ & $\begin{array}{r}-1.1390 \\
0.2000\end{array}$ & $\begin{array}{l}0.0000 \\
0.0000\end{array}$ & $\begin{array}{l}0.0000 \\
0.0000\end{array}$ & $\begin{array}{l}0.0000 \\
0.0000\end{array}$ & $\begin{array}{l}0.0000 \\
0.0000\end{array}$ & $\begin{array}{r}-0.2430 \\
0.0290\end{array}$ & $\begin{array}{r}-0.0089 \\
0.0000\end{array}$ & 0.9600 \\
\hline LUXEMBDURB & $\begin{array}{l}0.1454 \\
0.0000\end{array}$ & $\begin{array}{l}4.3260 \\
0.0460\end{array}$ & $\begin{array}{r}-4.1530 \\
0.0465\end{array}$ & $\begin{array}{r}10.9960 \\
0.1460\end{array}$ & $\begin{array}{l}0.0003 \\
0.0001\end{array}$ & $\begin{array}{l}0.0000 \\
0.0000\end{array}$ & $\begin{array}{l}0.0000 \\
0.0000\end{array}$ & $\begin{array}{r}-0.0120 \\
0.0001\end{array}$ & $\begin{array}{l}0.6866 \\
0.0072\end{array}$ & $\begin{array}{r}-0.0309 \\
0.0020\end{array}$ & 0.9900 \\
\hline NETHERL. & $\begin{array}{l}1.8390 \\
0.0000\end{array}$ & $\begin{array}{l}0.0000 \\
0.0000\end{array}$ & $\begin{array}{r}-0.4070 \\
0.0943\end{array}$ & $\begin{array}{l}0.0000 \\
0.0000\end{array}$ & $\begin{array}{r}-0.0020 \\
0.0003\end{array}$ & $\begin{array}{l}0.0000 \\
0.0000\end{array}$ & $\begin{array}{l}0.0000 \\
0.0000\end{array}$ & $\begin{array}{r}-0.0059 \\
0.0004\end{array}$ & $\begin{array}{l}0.5910 \\
0.0488\end{array}$ & $\begin{array}{l}0.2198 \\
0.0264\end{array}$ & 0.9900 \\
\hline NORHAY & $\begin{array}{l}1.1020 \\
0.0000\end{array}$ & $\begin{array}{l}0.0000 \\
0.0000\end{array}$ & $\begin{array}{l}0.2170 \\
0.0390\end{array}$ & $\begin{array}{l}2.9678 \\
0.4070\end{array}$ & $\begin{array}{r}-0.0036 \\
0.0002\end{array}$ & $\begin{array}{l}0.0000 \\
0.0000\end{array}$ & $\begin{array}{l}0.0000 \\
0.0000\end{array}$ & $\begin{array}{r}-0.0067 \\
0.0006\end{array}$ & $\begin{array}{l}0.1550 \\
0.0340\end{array}$ & $\begin{array}{l}0.3260 \\
0.0640\end{array}$ & 0.9900 \\
\hline
\end{tabular}


TABLE III.2 CONTD.

REGRESSION COEFFICIENTS FOR MODEL II

$\begin{array}{llllllllll}a(0) & a(1) & a(2) & a(3) & a(4) & a(5) & a(6) & a(7) & a(8) & \end{array}$

\begin{tabular}{|c|c|c|c|c|c|c|c|c|c|c|c|}
\hline PORTUGAL & $\begin{array}{l}0.5703 \\
0.0000\end{array}$ & $\begin{array}{l}0.0000 \\
0.0000\end{array}$ & $\begin{array}{l}0.5940 \\
0.2430\end{array}$ & $\begin{array}{r}-0.7830 \\
0.2930\end{array}$ & $\begin{array}{r}-0.0024 \\
0.0007\end{array}$ & $\begin{array}{l}0.0000 \\
0.0000\end{array}$ & $\begin{array}{l}0.0000 \\
0.0000\end{array}$ & $\begin{array}{l}0.0000 \\
0.0000\end{array}$ & $\begin{array}{r}-0.4760 \\
0.0690\end{array}$ & $\begin{array}{l}0.2020 \\
0.1250\end{array}$ & 0.9800 \\
\hline SPAIN & $\begin{array}{l}0.3994 \\
0.0000\end{array}$ & $\begin{array}{l}0.0000 \\
0.0000\end{array}$ & $\begin{array}{l}0.9450 \\
0.1830\end{array}$ & $\begin{array}{r}-0.9670 \\
0.1810\end{array}$ & $\begin{array}{r}-0.0023 \\
0.0004\end{array}$ & $\begin{array}{l}0.0000 \\
0.0000\end{array}$ & $\begin{array}{r}-0.0034 \\
0.0007\end{array}$ & $\begin{array}{r}-0.0031 \\
0.0005\end{array}$ & $\begin{array}{l}0.0000 \\
0.0000\end{array}$ & $\begin{array}{l}0.0000 \\
0.0000\end{array}$ & 0.9800 \\
\hline SWEDEN & $\begin{array}{l}2.3990 \\
0.0000\end{array}$ & $\begin{array}{l}0.0000 \\
0.0000\end{array}$ & $\begin{array}{l}0.0000 \\
0.0000\end{array}$ & $\begin{array}{l}0.0000 \\
0.0000\end{array}$ & $\begin{array}{r}-0.0048 \\
0.0004\end{array}$ & $\begin{array}{l}0.0000 \\
0.0000\end{array}$ & $\begin{array}{l}0.0000 \\
0.0000\end{array}$ & $\begin{array}{r}-0.0042 \\
0.0007\end{array}$ & $\begin{array}{l}0.6310 \\
0.0770\end{array}$ & $\begin{array}{l}0.0899 \\
0.0000\end{array}$ & 0.9800 \\
\hline SUITZERL. & $\begin{array}{l}0.1960 \\
0.0000\end{array}$ & $\begin{array}{l}0.7227 \\
0.0700\end{array}$ & $\begin{array}{r}-0.3590 \\
0.0570\end{array}$ & $\begin{array}{l}0.0000 \\
0.0000\end{array}$ & $\begin{array}{r}-0.0017 \\
0.0003\end{array}$ & $\begin{array}{l}0.0000 \\
0.0000\end{array}$ & $\begin{array}{r}-0.0064 \\
0.0008\end{array}$ & $\begin{array}{l}0.0000 \\
0.0000\end{array}$ & $\begin{array}{l}0.0000 \\
0.0000\end{array}$ & $\begin{array}{l}0.0000 \\
0.0000\end{array}$ & 0.9600 \\
\hline U.K. & $\begin{array}{l}0.4982 \\
0.0000\end{array}$ & $\begin{array}{r}-0.1390 \\
0.0290\end{array}$ & $\begin{array}{l}0.0000 \\
0.0000\end{array}$ & $\begin{array}{r}-0.5414 \\
0.3560\end{array}$ & $\begin{array}{l}0.0000 \\
0.0000\end{array}$ & $\begin{array}{l}0.0000 \\
0.0000\end{array}$ & $\begin{array}{l}0.0000 \\
0.0000\end{array}$ & $\begin{array}{r}-0.0024 \\
0.0010\end{array}$ & $\begin{array}{l}0.0492 \\
0.0489\end{array}$ & $\begin{array}{l}0.0000 \\
0.0000\end{array}$ & 0.8800 \\
\hline CANada & $\begin{array}{l}0.4440 \\
0.0000\end{array}$ & $\begin{array}{l}0.0000 \\
0.0000\end{array}$ & $\begin{array}{r}-0.0200 \\
0.0135\end{array}$ & $\begin{array}{r}-1.0350 \\
0.0784\end{array}$ & $\begin{array}{l}0.0000 \\
0.0000\end{array}$ & $\begin{array}{l}0.0000 \\
0.0000\end{array}$ & $\begin{array}{l}0.0640 \\
0.0310\end{array}$ & $\begin{array}{r}-0.0716 \\
0.0299\end{array}$ & $\begin{array}{l}2.9760 \\
1.2640\end{array}$ & $\begin{array}{l}0.0000 \\
0.0000\end{array}$ & 0.9800 \\
\hline U.8. & $\begin{array}{l}0.0252 \\
0.0000\end{array}$ & $\begin{array}{l}0.0000 \\
0.0000\end{array}$ & $\begin{array}{l}0.0000 \\
0.0000\end{array}$ & $\begin{array}{r}-0.6990 \\
0.0012\end{array}$ & $\begin{array}{l}0.0000 \\
0.0000\end{array}$ & $\begin{array}{l}0.0000 \\
0.0000\end{array}$ & $\begin{array}{l}0.0000 \\
0.0000\end{array}$ & $\begin{array}{l}0.0000 \\
0.0000\end{array}$ & $\begin{array}{r}-0.2070 \\
0.0001\end{array}$ & $\begin{array}{l}0.0000 \\
0.0000\end{array}$ & 0.8900 \\
\hline
\end{tabular}


TABLE III.3

REGRESSION COEFFICIENTS FOR MODEL III

\begin{tabular}{|c|c|c|c|c|c|c|c|c|c|c|c|}
\hline & $a(0)$ & $a(1)$ & $B(2)$ & $a(3)$ & $a(4)$ & $B(5)$ & $a(b)$ & $=(7)$ & $a(8)$ & $8(9)$ & R-SQR \\
\hline AUSTRIA & $\begin{array}{l}7.9306 \\
0.0000\end{array}$ & $\begin{array}{l}0.0000 \\
0.0000\end{array}$ & $\begin{array}{l}0.0000 \\
0.0000\end{array}$ & $\begin{array}{r}-1.2979 \\
0.5928\end{array}$ & $\begin{array}{l}0.0000 \\
0.0000\end{array}$ & $\begin{array}{l}0.0000 \\
0.0000\end{array}$ & $\begin{array}{r}-0.3781 \\
0.0978\end{array}$ & $\begin{array}{l}0.0000 \\
0.0000\end{array}$ & $\begin{array}{l}0.0000 \\
0.0000\end{array}$ & $\begin{array}{l}0.4741 \\
0.0483\end{array}$ & 0.9500 \\
\hline BELGIUH & $\begin{array}{r}10.4270 \\
0.0000\end{array}$ & $\begin{array}{l}0.0000 \\
0.0000\end{array}$ & $\begin{array}{l}0.0000 \\
0.0000\end{array}$ & $\begin{array}{l}0.0000 \\
0.0000\end{array}$ & $\begin{array}{r}-0.4996 \\
0.1594\end{array}$ & $\begin{array}{l}0.0000 \\
0.0000\end{array}$ & $\begin{array}{l}0.0000 \\
0.0000\end{array}$ & $\begin{array}{r}-0.3829 \\
0.0409\end{array}$ & $\begin{array}{l}0.2807 \\
0.0635\end{array}$ & $\begin{array}{l}0.5631 \\
0.0516\end{array}$ & 0.9800 \\
\hline DENHARK & $\begin{array}{r}11.8990 \\
0.0000\end{array}$ & $\begin{array}{r}-0.8285 \\
0.1944\end{array}$ & $\begin{array}{l}0.0000 \\
0.0000\end{array}$ & $\begin{array}{l}0.0000 \\
0.0000\end{array}$ & $\begin{array}{r}-0.5426 \\
0.1877\end{array}$ & $\begin{array}{l}0.0000 \\
0.0000\end{array}$ & $\begin{array}{l}0.0000 \\
0.0000\end{array}$ & $\begin{array}{r}-0.3084 \\
0.0615\end{array}$ & $\begin{array}{l}0.2608 \\
0.0800\end{array}$ & $\begin{array}{l}0.3203 \\
0.1446\end{array}$ & $0.5>00$ \\
\hline GERMANY & $\begin{array}{l}5.4075 \\
0.0000\end{array}$ & $\begin{array}{l}0.0000 \\
0.0000\end{array}$ & $\begin{array}{r}-0.6445 \\
0.1622\end{array}$ & $\begin{array}{r}-0.3709 \\
0.1713\end{array}$ & $\begin{array}{l}0.0000 \\
0.0000\end{array}$ & $\begin{array}{l}0.0000 \\
0.0000\end{array}$ & $\begin{array}{r}-0.1587 \\
0.0245\end{array}$ & $\begin{array}{l}0.0000 \\
0.0000\end{array}$ & $\begin{array}{l}0.0000 \\
0.0000\end{array}$ & $\begin{array}{l}0.8002 \\
0.0925\end{array}$ & 0.9900 \\
\hline ITALY & $\begin{array}{l}7.9239 \\
0.0000\end{array}$ & $\begin{array}{l}0.0000 \\
0.0000\end{array}$ & $\begin{array}{r}-1.1621 \\
0.5052\end{array}$ & $\begin{array}{l}0.0000 \\
0.0000\end{array}$ & $\begin{array}{l}0.0000 \\
0.0000\end{array}$ & $\begin{array}{l}0.0000 \\
0.0000\end{array}$ & $\begin{array}{r}-0.2232 \\
0.1300\end{array}$ & $\begin{array}{r}-0.4281 \\
0.0747\end{array}$ & $\begin{array}{l}0.0000 \\
0.0000\end{array}$ & $\begin{array}{l}0.8069 \\
0.2155\end{array}$ & 0.9700 \\
\hline LUXEHGOURB & $\begin{array}{l}1.3522 \\
0.0000\end{array}$ & $\begin{array}{l}1.0531 \\
0.3691\end{array}$ & $\begin{array}{r}-0.7465 \\
0.3344\end{array}$ & $\begin{array}{l}0.0000 \\
0.0000\end{array}$ & $\begin{array}{l}0.8628 \\
0.1937\end{array}$ & $\begin{array}{l}0.0000 \\
0.0000\end{array}$ & $\begin{array}{l}7.2637 \\
1.2986\end{array}$ & $\begin{array}{r}-7.4530 \\
1.2418\end{array}$ & $\begin{array}{l}6.5386 \\
1.1096\end{array}$ & $\begin{array}{l}0.0000 \\
0.0000\end{array}$ & 0.9900 \\
\hline NETHERL. & $\begin{array}{r}11.0193 \\
0.0000\end{array}$ & $\begin{array}{l}0.0000 \\
0.0000\end{array}$ & $\begin{array}{r}-1.0180 \\
0.4606\end{array}$ & $\begin{array}{l}0.0000 \\
0.0000\end{array}$ & $\begin{array}{r}-0.4226 \\
0.2206\end{array}$ & $\begin{array}{l}0.0000 \\
0.0000\end{array}$ & $\begin{array}{r}-0.4436 \\
0.0598\end{array}$ & $\begin{array}{l}0.0000 \\
0.0000\end{array}$ & $\begin{array}{l}0.2631 \\
0.0911\end{array}$ & $\begin{array}{l}0.6654 \\
0.1588\end{array}$ & 0.9600 \\
\hline NORHAY & $\begin{array}{r}11.8920 \\
0.0000\end{array}$ & $\begin{array}{l}0.0000 \\
0.0000\end{array}$ & $\begin{array}{l}0.6057 \\
0.1778\end{array}$ & $\begin{array}{l}3.3990 \\
0.7317\end{array}$ & $\begin{array}{r}-0.6949 \\
0.1739\end{array}$ & $\begin{array}{l}0.0000 \\
0.0000\end{array}$ & $\begin{array}{r}-0.1145 \\
0.0599\end{array}$ & $\begin{array}{r}-0.4082 \\
0.0387\end{array}$ & $\begin{array}{l}0.0000 \\
0.0000\end{array}$ & $\begin{array}{l}0.3241 \\
0.0884\end{array}$ & 0.9900 \\
\hline
\end{tabular}


TABLE III.3 CONTD.

REGRESSION COEFFICIENTS FOR MODEL III

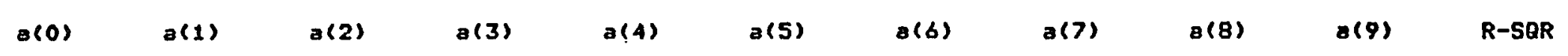

\begin{tabular}{|c|c|c|c|c|c|c|c|c|c|c|c|}
\hline PORTUGAL & $\begin{array}{l}6.2790 \\
0.0000\end{array}$ & $\begin{array}{l}0.0000 \\
0.0000\end{array}$ & $\begin{array}{l}0.0000 \\
0.0000\end{array}$ & $\begin{array}{r}-0.2986 \\
0.0770\end{array}$ & $\begin{array}{l}0.0000 \\
0.0000\end{array}$ & $\begin{array}{l}0.0000 \\
0.0000\end{array}$ & $\begin{array}{l}0.0000 \\
0.0000\end{array}$ & $\begin{array}{l}0.0000 \\
0.0000\end{array}$ & $\begin{array}{r}-0.3946 \\
0.0391\end{array}$ & $\begin{array}{l}0.3312 \\
0.0113\end{array}$ & 0.9600 \\
\hline SPAIN & $\begin{array}{l}3.1438 \\
0.0000\end{array}$ & $\begin{array}{l}0.0000 \\
0.0000\end{array}$ & $\begin{array}{l}0.0000 \\
0.0000\end{array}$ & $\begin{array}{l}0.0000 \\
0.0000\end{array}$ & $\begin{array}{l}0.5792 \\
0.1864\end{array}$ & $\begin{array}{l}0.0000 \\
0.0000\end{array}$ & $\begin{array}{l}0.0000 \\
0.0000\end{array}$ & $\begin{array}{r}-0.1771 \\
0.0435\end{array}$ & $\begin{array}{l}0.0000 \\
0.0000\end{array}$ & $\begin{array}{l}0.1519 \\
0.0920\end{array}$ & 0.9900 \\
\hline SWEDEN & $\begin{array}{r}15.6915 \\
0.0000\end{array}$ & $\begin{array}{r}-0.3030 \\
0.5200\end{array}$ & $\begin{array}{l}0.0000 \\
0.0000\end{array}$ & $\begin{array}{l}0.6372 \\
0.5316\end{array}$ & $\begin{array}{r}-1.2921 \\
0.2975\end{array}$ & $\begin{array}{l}0.0000 \\
0.0000\end{array}$ & $\begin{array}{l}0.0000 \\
0.0000\end{array}$ & $\begin{array}{r}-0.3435 \\
0.0618\end{array}$ & $\begin{array}{l}0.6718 \\
0.0925\end{array}$ & $\begin{array}{l}0.3841 \\
0.3053\end{array}$ & 0.9600 \\
\hline SWITZERL. & $\begin{array}{l}6.0169 \\
0.0000\end{array}$ & $\begin{array}{l}1.3809 \\
0.1499\end{array}$ & $\begin{array}{l}0.0000 \\
0.0000\end{array}$ & $\begin{array}{r}-0.7934 \\
0.2906\end{array}$ & $\begin{array}{l}0.0000 \\
0.0000\end{array}$ & $\begin{array}{l}0.0000 \\
0.0000\end{array}$ & $\begin{array}{l}0.0000 \\
0.0000\end{array}$ & $\begin{array}{r}-0.3088 \\
0.0757\end{array}$ & $\begin{array}{l}0.0000 \\
0.0000\end{array}$ & $\begin{array}{l}0.0000 \\
0.0000\end{array}$ & 0.9700 \\
\hline U.K. & $\begin{array}{l}0.0000 \\
0.0000\end{array}$ & $\begin{array}{l}0.0000 \\
0.0000\end{array}$ & $\begin{array}{l}0.0000 \\
0.0000\end{array}$ & $\begin{array}{l}0.0000 \\
0.0000\end{array}$ & $\begin{array}{l}0.0000 \\
0.0000\end{array}$ & $\begin{array}{l}0.0000 \\
0.0000\end{array}$ & $\begin{array}{l}0.0000 \\
0.0000\end{array}$ & $\begin{array}{l}0.0000 \\
0.0000\end{array}$ & $\begin{array}{l}0.0000 \\
0.0000\end{array}$ & $\begin{array}{l}0.0000 \\
0.0000\end{array}$ & 0.0000 \\
\hline CANADA & $\begin{array}{l}1.0309 \\
0.0000\end{array}$ & $\begin{array}{l}1.1039 \\
0.1633\end{array}$ & $\begin{array}{r}-1.1501 \\
0.2900\end{array}$ & $\begin{array}{l}0.0000 \\
0.0000\end{array}$ & $\begin{array}{l}1.0755 \\
0.3129\end{array}$ & $\begin{array}{l}0.0000 \\
0.0000\end{array}$ & $\begin{array}{r}-0.3899 \\
0.1314\end{array}$ & $\begin{array}{l}0.0000 \\
0.0000\end{array}$ & $\begin{array}{l}0.0000 \\
0.0000\end{array}$ & $\begin{array}{l}0.0000 \\
0.0000\end{array}$ & 0.9600 \\
\hline U.S. & $\begin{array}{l}0.6796 \\
0.0000\end{array}$ & $\begin{array}{l}0.0000 \\
0.0000\end{array}$ & $\begin{array}{l}0.0000 \\
0.0000\end{array}$ & $\begin{array}{r}-0.7553 \\
0.1136\end{array}$ & $\begin{array}{l}0.9488 \\
0.0752\end{array}$ & $\begin{array}{l}0.0000 \\
0.0000\end{array}$ & $\begin{array}{l}0.0000 \\
0.0000\end{array}$ & $\begin{array}{r}-0.0766 \\
0.0579\end{array}$ & $\begin{array}{r}-0.1638 \\
0.0495\end{array}$ & $\begin{array}{l}0.0000 \\
0.0000\end{array}$ & 0.9800 \\
\hline
\end{tabular}


TABLE III.4

REGRESSION COEFFICIENTS FOR MODEL IV

\begin{tabular}{|c|c|c|c|c|c|c|c|c|c|c|c|}
\hline & $a(0)$ & $a(1)$ & $a(2)$ & $a(3)$ & $a(4)$ & $a(5)$ & $a(6)$ & $a(7)$ & $a(B)$ & $a(9)$ & R-SQR \\
\hline AUSTRIA & $\begin{array}{l}1.2767 \\
0.0000\end{array}$ & $\begin{array}{l}0.0000 \\
0.0000\end{array}$ & $\begin{array}{l}0.0000 \\
0.0000\end{array}$ & $\begin{array}{r}-1.1940 \\
0.6650\end{array}$ & $\begin{array}{l}0.0000 \\
0.0000\end{array}$ & $\begin{array}{l}0.0000 \\
0.0000\end{array}$ & $\begin{array}{l}0.0000 \\
0.0000\end{array}$ & $\begin{array}{r}-0.2892 \\
0.0695\end{array}$ & $\begin{array}{l}0.0000 \\
0.0000\end{array}$ & $\begin{array}{l}0.0000 \\
0.0000\end{array}$ & 0.7300 \\
\hline BELGIUH & $\begin{array}{r}10.0800 \\
0.0000\end{array}$ & $\begin{array}{l}0.0000 \\
0.0000\end{array}$ & $\begin{array}{l}0.0000 \\
0.0000\end{array}$ & $\begin{array}{l}0.0000 \\
0.0000\end{array}$ & $\begin{array}{r}-1.4420 \\
0.1640\end{array}$ & $\begin{array}{l}0.0000 \\
0.0000\end{array}$ & $\begin{array}{l}0.5820 \\
0.4040\end{array}$ & $\begin{array}{r}-0.9615 \\
0.4060\end{array}$ & $\begin{array}{l}0,8070 \\
0: 3720\end{array}$ & $\begin{array}{l}0.5357 \\
0.0560\end{array}$ & 0.9900 \\
\hline DENMARK & $\begin{array}{r}11.7600 \\
0.0000\end{array}$ & $\begin{array}{r}-1.1073 \\
0.2120\end{array}$ & $\begin{array}{l}0.0000 \\
0.0000\end{array}$ & $\begin{array}{r}-0.6241 \\
0.3193\end{array}$ & $\begin{array}{r}-1.4384 \\
0.1450\end{array}$ & $\begin{array}{l}0.0000 \\
0.0000\end{array}$ & $\begin{array}{l}0.0000 \\
0.0000\end{array}$ & $\begin{array}{r}-0.3665 \\
0.0588\end{array}$ & $\begin{array}{l}0.3275 \\
0.0718\end{array}$ & $\begin{array}{l}0.5314 \\
0.1580\end{array}$ & 0.7800 \\
\hline GERMANY & $\begin{array}{l}4.9509 \\
0.0000\end{array}$ & $\begin{array}{r}-0.6846 \\
0.2262\end{array}$ & $\begin{array}{l}0.0000 \\
0.0000\end{array}$ & $\begin{array}{r}-1.0956 \\
0.1862\end{array}$ & $\begin{array}{r}-0.9117 \\
0.1510\end{array}$ & $\begin{array}{l}0.0000 \\
0.0000\end{array}$ & $\begin{array}{l}0.0000 \\
0.0000\end{array}$ & $\begin{array}{r}-0.1634 \\
0.0355\end{array}$ & $\begin{array}{l}0.1223 \\
0.0396\end{array}$ & $\begin{array}{l}0.7929 \\
0.1344\end{array}$ & 0.9800 \\
\hline ITALY & $\begin{array}{l}3.1634 \\
0.0000\end{array}$ & $\begin{array}{l}0.0000 \\
0.0000\end{array}$ & $\begin{array}{l}0.0000 \\
0.0000\end{array}$ & $\begin{array}{l}0.0000 \\
0.0000\end{array}$ & $\begin{array}{r}-0.6915 \\
0.1257\end{array}$ & $\begin{array}{l}0.0000 \\
0.0000\end{array}$ & $\begin{array}{r}-2.4972 \\
0.2854\end{array}$ & $\begin{array}{l}2.6746 \\
0.3399\end{array}$ & $\begin{array}{r}-2.5220 \\
0.2834\end{array}$ & $\begin{array}{l}0.1928 \\
0.0502\end{array}$ & 0.9900 \\
\hline LUXEHBOURG & $\begin{array}{l}0.6748 \\
0.0000\end{array}$ & $\begin{array}{l}0.2097 \\
0.1022\end{array}$ & $\begin{array}{l}0.0000 \\
0.0000\end{array}$ & $\begin{array}{r}-0.7759 \\
0.3314\end{array}$ & $\begin{array}{l}0.0000 \\
0.0000\end{array}$ & $\begin{array}{l}0.0000 \\
0.0000\end{array}$ & $\begin{array}{l}8.1096 \\
1.3036\end{array}$ & $\begin{array}{r}-8.3170 \\
1.2555\end{array}$ & $\begin{array}{l}7.2481 \\
1.1174\end{array}$ & $\begin{array}{l}0.0000 \\
0.0000\end{array}$ & 0.9800 \\
\hline NETHERL. & $\begin{array}{r}10.8565 \\
0.0000\end{array}$ & $\begin{array}{l}0.0000 \\
0.0000\end{array}$ & $\begin{array}{r}-0.9685 \\
0.4171\end{array}$ & $\begin{array}{l}0.0000 \\
0.0000\end{array}$ & $\begin{array}{r}-1.4124 \\
0.1998\end{array}$ & $\begin{array}{l}0.0000 \\
0.0000\end{array}$ & $\begin{array}{r}-0.4244 \\
0.0541\end{array}$ & $\begin{array}{l}0.0000 \\
0.0000\end{array}$ & $\begin{array}{l}0.2518 \\
0.0825\end{array}$ & $\begin{array}{l}0.6422 \\
0.1438\end{array}$ & 0.9800 \\
\hline NORWAY & $\begin{array}{l}9.2879 \\
0.0000\end{array}$ & $\begin{array}{l}0.6268 \\
0.0998\end{array}$ & $\begin{array}{l}0.0000 \\
0.0000\end{array}$ & $\begin{array}{l}2.5231 \\
0.7000\end{array}$ & $\begin{array}{r}-1.4006 \\
0.1562\end{array}$ & $\begin{array}{l}0.0000 \\
0.0000\end{array}$ & $\begin{array}{r}-1.1361 \\
0.4011\end{array}$ & $\begin{array}{l}0.8064 \\
0.4736\end{array}$ & $\begin{array}{r}-0.9407 \\
0.3713\end{array}$ & $\begin{array}{l}0.2018 \\
0.0684\end{array}$ & 0.9900 \\
\hline
\end{tabular}


TABLE III.4 CONTD.

REGRESSION COEFFICIENTS FOR MODEL IU

\begin{tabular}{|c|c|c|c|c|c|c|c|c|c|c|c|}
\hline & $\theta(0)$ & $a(1)$ & $a(2)$ & $3(3)$ & $a(4)$ & $a(5)$ & $a(b)$ & $a(7)$ & $a(8)$ & $B(9)$ & R-SQR \\
\hline PORTUGAL & $\begin{array}{l}2.8965 \\
0.0000\end{array}$ & $\begin{array}{l}0.0000 \\
0.0000\end{array}$ & $\begin{array}{l}0.0000 \\
0.0000\end{array}$ & $\begin{array}{r}-1.3375 \\
0.2219\end{array}$ & $\begin{array}{r}-0.2536 \\
0.2387\end{array}$ & $\begin{array}{l}0.0000 \\
0.0000\end{array}$ & $\begin{array}{r}-0.2791 \\
0.2123\end{array}$ & $\begin{array}{l}0.0000 \\
0.0000\end{array}$ & $\begin{array}{r}-0.6760 \\
0.1029\end{array}$ & $\begin{array}{l}0.0000 \\
0.0000\end{array}$ & 0.9500 \\
\hline SPAIN & $\begin{array}{l}7.7785 \\
0.0000\end{array}$ & $\begin{array}{l}0.0000 \\
0.0000\end{array}$ & $\begin{array}{r}-0.2682 \\
0.1733\end{array}$ & $\begin{array}{l}0.0000 \\
0.0000\end{array}$ & $\begin{array}{r}-1.1816 \\
0.1588\end{array}$ & $\begin{array}{l}0.0000 \\
0.0000\end{array}$ & $\begin{array}{l}0.0000 \\
0.0000\end{array}$ & $\begin{array}{r}-0.3100 \\
0.0426\end{array}$ & $\begin{array}{l}0.2235 \\
0.0377\end{array}$ & $\begin{array}{l}0.5882 \\
0.0836\end{array}$ & 0.9900 \\
\hline SWEDEN & $\begin{array}{r}15.9140 \\
0.0000\end{array}$ & $\begin{array}{l}0.0000 \\
0.0000\end{array}$ & $\begin{array}{l}0.0000 \\
0.0000\end{array}$ & $\begin{array}{l}0.8402 \\
0.2963\end{array}$ & $\begin{array}{r}-2.3868 \\
0.1802\end{array}$ & $\begin{array}{l}0.0000 \\
0.0000\end{array}$ & $\begin{array}{l}0.0000 \\
0.0000\end{array}$ & $\begin{array}{r}-0.3209 \\
0.0539\end{array}$ & $\begin{array}{l}0.6430 \\
0.0813\end{array}$ & $\begin{array}{l}0.2114 \\
0.0396\end{array}$ & 0.9900 \\
\hline SHITZERL. & $\begin{array}{l}0.8982 \\
0.0000\end{array}$ & $\begin{array}{l}0.4067 \\
0.1991\end{array}$ & $\begin{array}{l}0.0000 \\
0.0000\end{array}$ & $\begin{array}{r}-1.5346 \\
0.3814\end{array}$ & $\begin{array}{l}0.0000 \\
0.0000\end{array}$ & $\begin{array}{l}0.0000 \\
0.0000\end{array}$ & $\begin{array}{r}-0.3202 \\
0.0978\end{array}$ & $\begin{array}{l}0.0000 \\
0.0000\end{array}$ & $\begin{array}{r}-0.3780 \\
0.1862\end{array}$ & $\begin{array}{l}0.0000 \\
0.0000\end{array}$ & 0.8400 \\
\hline $\mathbf{U} \cdot \mathbf{K}$. & $\begin{array}{l}0.7317 \\
0.0000\end{array}$ & $\begin{array}{r}-0.2742 \\
0.0516\end{array}$ & $\begin{array}{l}0.0000 \\
0.0000\end{array}$ & $\begin{array}{r}-0.2953 \\
0.2378\end{array}$ & $\begin{array}{l}0.0000 \\
0.0000\end{array}$ & $\begin{array}{l}0.0000 \\
0.0000\end{array}$ & $\begin{array}{l}0.0000 \\
0.0000\end{array}$ & $\begin{array}{r}-0.1171 \\
0.0369\end{array}$ & $\begin{array}{l}0.0000 \\
0.0000\end{array}$ & $\begin{array}{l}0.0000 \\
0.0000\end{array}$ & 0.8700 \\
\hline CANADA & $\begin{array}{r}-2.5020 \\
0.0000\end{array}$ & $\begin{array}{l}0.0000 \\
0.0000\end{array}$ & $\begin{array}{r}-0.4589 \\
0.1439\end{array}$ & $\begin{array}{r}-1.2210 \\
0.0997\end{array}$ & $\begin{array}{l}0.4984 \\
0.2172\end{array}$ & $\begin{array}{l}0.0000 \\
0.0000\end{array}$ & $\begin{array}{l}9.5236 \\
2.7630\end{array}$ & $\begin{array}{r}-9.6278 \\
2.6690\end{array}$ & $\begin{array}{l}9.6690 \\
2.6950\end{array}$ & $\begin{array}{l}0.0000 \\
0.0000\end{array}$ & 0.9900 \\
\hline $\mathbf{U . 5}$ & $\begin{array}{l}2.2458 \\
0.0000\end{array}$ & $\begin{array}{l}0.0000 \\
0.0000\end{array}$ & $\begin{array}{r}-0.7409 \\
0.1062\end{array}$ & $\begin{array}{l}0.0000 \\
0.0000\end{array}$ & $\begin{array}{l}0.0000 \\
0.0000\end{array}$ & $\begin{array}{l}0.0000 \\
0.0000\end{array}$ & $\begin{array}{l}0.0000 \\
0.0000\end{array}$ & $\begin{array}{l}0.0000 \\
0.0493\end{array}$ & $\begin{array}{r}-0.1830 \\
0.0420\end{array}$ & $\begin{array}{l}0.0000 \\
0.0000\end{array}$ & 0.9100 \\
\hline
\end{tabular}


"triplets" appearing stmaltaneously, unless such models showed highly insignificent parameter estimates. Notably, the models not containing the triplets displayed higher statistical significance of the parameter estimates in most cases.

Tables III.l through III.4 distinctly indicate that, while the values of R-SQR. were generally high for all four models, the statistical significance of the estimates (measured by the F-values) was much better for model I.

Model I was therefore adopted and further analyzed.

Further analysis of the model was designed for the purpose of exploring the tendency of the estimates of the model parameters to vary upon deleting various variables. Such variability can serve as a measure of the regression sensitivity to multicolinearity aso:y the explanatory variables. The analysis was systematically pursued by considering the following different modifications of model I :

Mode 1.1: Model I with lagged variables removed. In this version of the model, the lagged variables were removed resulting in the following mathematical form:

$D(t)=a(0)+a(2) \cdot G(t)+a(3) \cdot g+a(6) \cdot P(t)+a(7) \cdot p+a(8) \cdot N(t)$ 
TAELE III.5

REGRESSION COEFFICIENTS FOR MONEL I.1

\begin{tabular}{|c|c|c|c|c|c|c|c|c|c|c|}
\hline & $a(0)$ & $a(1)$ & $a(2)$ & $a(3)$ & $a(4)$ & $B(5)$ & $a(6)$ & $a(7)$ & $a(8)$ & R-SQR \\
\hline AUSTRIA & $\begin{array}{r}759.71 \\
0.00\end{array}$ & $\begin{array}{l}0.00 \\
0.00\end{array}$ & $\begin{array}{r}-306.96 \\
8.30\end{array}$ & $\begin{array}{l}0.00 \\
0.00\end{array}$ & $\begin{array}{l}0.00 \\
0.00\end{array}$ & $\begin{array}{l}0.00 \\
0.00\end{array}$ & $\begin{array}{l}-2.98 \\
36.97\end{array}$ & $\begin{array}{r}270.32 \\
16.14\end{array}$ & $\begin{array}{r}474.14 \\
25.24\end{array}$ & 0.97 \\
\hline BELGIUH & $\begin{array}{r}474.32 \\
0.00\end{array}$ & $\begin{array}{l}0.00 \\
0.00\end{array}$ & $\begin{array}{r}-65.24 \\
3.87\end{array}$ & $\begin{array}{l}0.00 \\
0.00\end{array}$ & $\begin{array}{l}0.00 \\
0.00\end{array}$ & $\begin{array}{l}0.00 \\
0.00\end{array}$ & $\begin{array}{l}-1.79 \\
80.27\end{array}$ & $\begin{array}{r}120 \cdot 34 \\
21.74\end{array}$ & $\begin{array}{r}134.44 \\
33.54\end{array}$ & 0.98 \\
\hline DENAARK & $\begin{array}{r}1016.52 \\
0.00\end{array}$ & $\begin{array}{l}0.00 \\
0.00\end{array}$ & $\begin{array}{r}-192.92 \\
18.39\end{array}$ & $\begin{array}{l}0.00 \\
0.00\end{array}$ & $\begin{array}{l}0.00 \\
0.00\end{array}$ & $\begin{array}{l}0.00 \\
0.00\end{array}$ & $\begin{array}{l}-2.38 \\
36.18\end{array}$ & $\begin{array}{r}160 \cdot 25 \\
11.32\end{array}$ & $\begin{array}{r}239.45 \\
9.63\end{array}$ & 0.96 \\
\hline GERHANY & $\begin{array}{r}475.41 \\
0.00\end{array}$ & $\begin{array}{l}0.00 \\
0.00\end{array}$ & $\begin{array}{r}-104.32 \\
16.04\end{array}$ & $\begin{array}{l}0.00 \\
0.00\end{array}$ & $\begin{array}{l}0.00 \\
0.00\end{array}$ & $\begin{array}{l}0.00 \\
0.00\end{array}$ & $\begin{array}{l}-1.04 \\
20.39\end{array}$ & $\begin{array}{l}64.14 \\
10.39\end{array}$ & $\begin{array}{l}26.11 \\
84.22\end{array}$ & 9.98 \\
\hline ITALY & $\begin{array}{r}586.02 \\
0.00\end{array}$ & $\begin{array}{l}0.00 \\
0.00\end{array}$ & $\begin{array}{l}0.00 \\
0.00\end{array}$ & $\begin{array}{l}0.00 \\
0.00\end{array}$ & $\begin{array}{l}0.00 \\
0.00\end{array}$ & $\begin{array}{l}0.00 \\
0.00\end{array}$ & $\begin{array}{l}-2.38 \\
20.81\end{array}$ & $\begin{array}{l}0.00 \\
0.00\end{array}$ & $\begin{array}{l}17 \cdot 21 \\
81.28\end{array}$ & 0.96 \\
\hline LUXEMBOURG & $\begin{array}{r}-199.63 \\
0.00\end{array}$ & $\begin{array}{l}0.00 \\
0.00\end{array}$ & $\begin{array}{r}276.62 \\
26.28\end{array}$ & $\begin{array}{r}-1702.58 \\
20.78\end{array}$ & $\begin{array}{l}0.00 \\
0.00\end{array}$ & $\begin{array}{l}0.00 \\
0.00\end{array}$ & $\begin{array}{l}0.00 \\
0.00\end{array}$ & $\begin{array}{l}0.00 \\
0.00\end{array}$ & $\begin{array}{l}0.00 \\
0.00\end{array}$ & 0.87 \\
\hline NETHERL. & $\begin{array}{r}979.74 \\
0.00\end{array}$ & $\begin{array}{l}0.00 \\
0.00\end{array}$ & $\begin{array}{r}-236.44 \\
60.36\end{array}$ & $\begin{array}{l}0.00 \\
0.00\end{array}$ & $\begin{array}{l}0.00 \\
0.00\end{array}$ & $\begin{array}{l}0.00 \\
0.00\end{array}$ & $\begin{array}{r}-3.27 \\
359.37\end{array}$ & $\begin{array}{l}320.85 \\
164.20\end{array}$ & $\begin{array}{l}123.67 \\
137.95\end{array}$ & 0.99 \\
\hline NORWAY & $\begin{array}{r}351.15 \\
0.00\end{array}$ & $\begin{array}{l}0.00 \\
0.00\end{array}$ & $\begin{array}{l}0.00 \\
0.00\end{array}$ & $\begin{array}{r}1005.77 \\
5.57\end{array}$ & $\begin{array}{l}0.00 \\
0.00\end{array}$ & $\begin{array}{l}0.00 \\
0.00\end{array}$ & $\begin{array}{r}-1.62 \\
45.89\end{array}$ & $\begin{array}{l}0.00 \\
0.00\end{array}$ & $\begin{array}{l}211.64 \\
100.63\end{array}$ & 0.95 \\
\hline
\end{tabular}


TABLE III.5 CONTD.

REGRESSION COEFFICIENTS FOR MONEL I. 1

\begin{tabular}{|c|c|c|c|c|c|c|c|c|c|c|}
\hline & $a(0)$ & $a(1)$ & $a(2)$ & $a(3)$ & $a(4)$ & $a(5)$ & $a(6)$ & $a(7)$ & $a(8)$ & $R-S R R$ \\
\hline PORTUGAL & $\begin{array}{r}244.05 \\
0.00\end{array}$ & $\begin{array}{l}0.00 \\
0.00\end{array}$ & $\begin{array}{r}194.95 \\
6.62\end{array}$ & $\begin{array}{r}-296.59 \\
7.76\end{array}$ & $\begin{array}{l}0.00 \\
0.00\end{array}$ & $\begin{array}{l}0.00 \\
0.00\end{array}$ & $\begin{array}{l}0.00 \\
0.00\end{array}$ & $\begin{array}{r}-234.24 \\
109.11\end{array}$ & $\begin{array}{r}125.20 \\
9.06\end{array}$ & 0.99 \\
\hline SPAIN & $\begin{array}{r}137.67 \\
0.00\end{array}$ & $\begin{array}{l}0.00 \\
0.00\end{array}$ & $\begin{array}{r}449.93 \\
1735.51\end{array}$ & $\begin{array}{r}-315.61 \\
10.59\end{array}$ & $\begin{array}{l}0.00 \\
0.00\end{array}$ & $\begin{array}{l}0.00 \\
0.00\end{array}$ & $\begin{array}{r}-3.09 \\
222.78\end{array}$ & $\begin{array}{l}95.76 \\
25.89\end{array}$ & $\begin{array}{l}0.00 \\
0.00\end{array}$ & 0.99 \\
\hline SWELIEN & $\begin{array}{r}878.09 \\
0.00\end{array}$ & $\begin{array}{l}0.00 \\
0.00\end{array}$ & $\begin{array}{r}-208.52 \\
7.79\end{array}$ & $\begin{array}{r}329.25 \\
1.01\end{array}$ & $\begin{array}{l}0.00 \\
0.00\end{array}$ & $\begin{array}{l}0.00 \\
0.00\end{array}$ & $\begin{array}{r}-1.93 \\
6.27\end{array}$ & $\begin{array}{r}246.38 \\
10.09\end{array}$ & $\begin{array}{r}236.68 \\
10.16\end{array}$ & 0.81 \\
\hline SWITZERL. & $\begin{array}{r}238.66 \\
0.00\end{array}$ & $\begin{array}{l}0.00 \\
0.00\end{array}$ & $\begin{array}{r}135.07 \\
7.78\end{array}$ & $\begin{array}{r}-1176.12 \\
26.62\end{array}$ & $\begin{array}{l}0: 00 \\
0.00\end{array}$ & $\begin{array}{l}0.00 \\
0.00\end{array}$ & $\begin{array}{l}-3.35 \\
51.79\end{array}$ & $\begin{array}{r}183.79 \\
6.99\end{array}$ & $\begin{array}{r}74.28 \\
3.66\end{array}$ & 0.99 \\
\hline $\mathbf{U} \cdot \mathbf{K}$. & $\begin{array}{r}350.08 \\
0.00\end{array}$ & $\begin{array}{l}0.00 \\
0.00\end{array}$ & $\begin{array}{r}217.89 \\
89.26\end{array}$ & $\begin{array}{l}0.00 \\
0.00\end{array}$ & $\begin{array}{l}0.00 \\
0.00\end{array}$ & $\begin{array}{l}0.00 \\
0.00\end{array}$ & $\begin{array}{l}-2.39 \\
19.58\end{array}$ & $\begin{array}{r}60.92 \\
3.89\end{array}$ & $\begin{array}{l}0.00 \\
0.00\end{array}$ & 0.96 \\
\hline CANADA & $\begin{array}{r}1608.41 \\
0.00\end{array}$ & $\begin{array}{l}0.00 \\
0.00\end{array}$ & $\begin{array}{l}0.00 \\
0.00\end{array}$ & $\begin{array}{r}612.49 \\
15.89\end{array}$ & $\begin{array}{l}0.00 \\
0.00\end{array}$ & $\begin{array}{l}0.00 \\
0.00\end{array}$ & $\begin{array}{r}-13.61 \\
5.90\end{array}$ & $\begin{array}{r}441.56 \\
6.75\end{array}$ & $\begin{array}{l}35.43 \\
47.14\end{array}$ & 0.94 \\
\hline U.S. & $\begin{array}{r}2415.68 \\
0.00\end{array}$ & $\begin{array}{l}0.00 \\
0.00\end{array}$ & $\begin{array}{r}-229.23 \\
11.19\end{array}$ & $\begin{array}{l}0.00 \\
0.00\end{array}$ & $\begin{array}{l}0.00 \\
0.00\end{array}$ & $\begin{array}{l}0.00 \\
0.00\end{array}$ & $\begin{array}{r}-18.88 \\
22.47\end{array}$ & $\begin{array}{r}292.74 \\
5.58\end{array}$ & $\begin{array}{r}7.72 \\
46.48\end{array}$ & 0.96 \\
\hline
\end{tabular}


that of $d(t)$ removed, were maintained in the current and subsequent models for the ease of inter model comparisons. Table III.5 contains the regression results of model I.1. The zero columns in the table (and the tables of the subsequent models) correspond to the originally hypothesized variables which are absent in the current model.

Model I.2: Model I.1 with $N(t)$ Removed

Due to the high correlation of $N(t)$ with several of the model variables, it was removed in the current version of model I resulting in the following model:

$$
D(t)=a(0)+a(2) \cdot G(t)+a(3) \cdot g+a(6) \cdot P(t)+a(7) \cdot p
$$

The regression results of model $I .2$ are displayed in table III.6.

Model I.3: Model I with Current Variables Removed

Removing the current variables from model I resulted in model I.3 having the following mathematical form:

$D(t)=a(0)+a(1) \cdot G(t-1)+a(3) \cdot g+a(4) \cdot D(t-1)+a(5) \cdot P(t-1)+a(7) \cdot p$

Table III.7 contains the regression coefficients of model I.3.

Model I.4: Model I.3 With $\mathrm{N}(t)$ Added And $D(t-1)$ Removed

Again, $N(t)$ was inserted in model $I .3$ due to its strong correlation with the explanatory variables resulting in the 
TABLE III.6

REGRESSION COEFFICIENTS FOR MONEL I.2

\begin{tabular}{|c|c|c|c|c|c|c|c|c|c|c|}
\hline & $a(0)$ & $a(1)$ & $a(2)$ & $a(3)$ & $3(4)$ & $a(5)$ & $a(6)$ & $a(7)$ & $a(8)$ & $\mathrm{R}-\mathrm{SQR}$ \\
\hline AUSTRIA & $\begin{array}{r}283.03 \\
0.00\end{array}$ & $\begin{array}{l}0.00 \\
0.00\end{array}$ & $\begin{array}{r}228.41 \\
22.20\end{array}$ & $\begin{array}{l}0.00 \\
0.00\end{array}$ & $\begin{array}{l}0.00 \\
0.00\end{array}$ & $\begin{array}{l}0.00 \\
0.00\end{array}$ & $\begin{array}{r}-1.13 \\
4.60\end{array}$ & $\begin{array}{l}0.00 \\
0.00\end{array}$ & $\begin{array}{l}0.00 \\
0.00\end{array}$ & 0.81 \\
\hline BELGIUM & $\begin{array}{r}315.12 \\
0.00\end{array}$ & $\begin{array}{l}0.00 \\
0.00\end{array}$ & $\begin{array}{r}122.21 \\
50.79\end{array}$ & $\begin{array}{l}0.00 \\
0.00\end{array}$ & $\begin{array}{l}0.00 \\
0.00\end{array}$ & $\begin{array}{l}0.00 \\
0.00\end{array}$ & $\begin{array}{r}-2.12 \\
5.72\end{array}$ & $\begin{array}{l}0.00 \\
0.00\end{array}$ & $\begin{array}{l}0.00 \\
0.00\end{array}$ & 0.88 \\
\hline DENMARK & $\begin{array}{r}810.86 \\
0.00\end{array}$ & $\begin{array}{l}0.00 \\
0.00\end{array}$ & $\begin{array}{r}-50.24 \\
14.87\end{array}$ & $\begin{array}{l}0.00 \\
0.00\end{array}$ & $\begin{array}{l}0.00 \\
0.00\end{array}$ & $\begin{array}{l}0.00 \\
0.00\end{array}$ & $\begin{array}{r}-1.34 \\
11.71\end{array}$ & $\begin{array}{l}0.00 \\
0.00\end{array}$ & $\begin{array}{l}0.00 \\
0.00\end{array}$ & 0.86 \\
\hline GERMANY & $\begin{array}{r}180.73 \\
0.00\end{array}$ & $\begin{array}{l}0.00 \\
0.00\end{array}$ & $\begin{array}{r}127 \cdot 32 \\
16.15\end{array}$ & $\begin{array}{r}-558.55 \\
6.69\end{array}$ & $\begin{array}{l}0.00 \\
0.00\end{array}$ & $\begin{array}{l}0.00 \\
0.00\end{array}$ & $\begin{array}{r}-0.77 \\
1.76\end{array}$ & $\begin{array}{l}0.00 \\
0.00\end{array}$ & $\begin{array}{l}0.00 \\
0.00\end{array}$ & 0.85 \\
\hline ITALY & $\begin{array}{r}179.32 \\
0.00\end{array}$ & $\begin{array}{l}0.00 \\
0.00\end{array}$ & $\begin{array}{r}235.29 \\
53.03\end{array}$ & $\begin{array}{l}0.00 \\
0.00\end{array}$ & $\begin{array}{l}0.00 \\
0.00\end{array}$ & $\begin{array}{l}0.00 \\
0.00\end{array}$ & $\begin{array}{l}0.00 \\
0.00\end{array}$ & $\begin{array}{r}-136.54 \\
15.05\end{array}$ & $\begin{array}{l}0.00 \\
0.00\end{array}$ & 0.89 \\
\hline LUXEMBOURG & $\begin{array}{r}-199.63 \\
0.00\end{array}$ & $\begin{array}{l}0.00 \\
0.00\end{array}$ & $\begin{array}{r}276.82 \\
26.26\end{array}$ & $\begin{array}{r}-1702.58 \\
20.78\end{array}$ & $\begin{array}{l}0.00 \\
0.00\end{array}$ & $\begin{array}{l}0.00 \\
0.00\end{array}$ & $\begin{array}{l}0.00 \\
0.00\end{array}$ & $\begin{array}{l}0.00 \\
0.00\end{array}$ & $\begin{array}{l}0.00 \\
0.00\end{array}$ & 0.87 \\
\hline NETHERL. & $\begin{array}{r}418.10 \\
0.00\end{array}$ & $\begin{array}{l}0.00 \\
0.00\end{array}$ & $\begin{array}{r}108.85 \\
8.02\end{array}$ & $\begin{array}{l}0.00 \\
0.00\end{array}$ & $\begin{array}{l}0.00 \\
0.00\end{array}$ & $\begin{array}{l}0.00 \\
0.00\end{array}$ & $\begin{array}{r}-1.98 \\
9.30\end{array}$ & $\begin{array}{r}88.13 \\
1.39\end{array}$ & $\begin{array}{l}0.00 \\
0.00\end{array}$ & 0.69 \\
\hline NORWAY & $\begin{array}{r}309.68 \\
0.00\end{array}$ & $\begin{array}{l}0.00 \\
0.00\end{array}$ & $\begin{array}{l}99.65 \\
64.25\end{array}$ & $\begin{array}{l}0.00 \\
0.00\end{array}$ & $\begin{array}{l}0.00 \\
0.00\end{array}$ & $\begin{array}{l}0.00 \\
0.00\end{array}$ & $\begin{array}{r}-1.87 \\
3.89\end{array}$ & $\begin{array}{l}0.00 \\
0.00\end{array}$ & $\begin{array}{l}0.00 \\
0.00\end{array}$ & 0.90 \\
\hline
\end{tabular}


TABLE III.6 CONTD.

REGRESSION COEFFICIENTS FOR MONEL I.2

\begin{tabular}{|c|c|c|c|c|c|c|c|c|c|c|}
\hline & $a(0)$ & $a(1)$ & $a(2)$ & $a(3)$ & $B(4)$ & $8(5)$ & $3(6)$ & $a(7)$ & $a(8)$ & R-SQR \\
\hline PORTUGAL & $\begin{array}{r}186.21 \\
0.00\end{array}$ & $\begin{array}{l}0.00 \\
0.00\end{array}$ & $\begin{array}{l}418.21 \\
305.76\end{array}$ & $\begin{array}{r}-599.37 \\
124.91\end{array}$ & $\begin{array}{l}0.00 \\
0.00\end{array}$ & $\begin{array}{l}0.00 \\
0.00\end{array}$ & $\begin{array}{l}0.00 \\
0.00\end{array}$ & $\begin{array}{r}-263.48 \\
72.51\end{array}$ & $\begin{array}{l}0.00 \\
0.00\end{array}$ & 0.98 \\
\hline SPAIN & $\begin{array}{r}137.67 \\
0.00\end{array}$ & $\begin{array}{l}0.00 \\
0.00\end{array}$ & $\begin{array}{r}449.93 \\
1736.00\end{array}$ & $\begin{array}{r}-315.61 \\
10.59\end{array}$ & $\begin{array}{l}0.00 \\
0.00\end{array}$ & $\begin{array}{l}0.00 \\
0.00\end{array}$ & $\begin{array}{r}-3.09 \\
222.78\end{array}$ & $\begin{array}{l}95.76 \\
25.90\end{array}$ & $\begin{array}{l}0.00 \\
0.00\end{array}$ & 0.99 \\
\hline SWEDEN & $\begin{array}{l}0.00 \\
0.00\end{array}$ & $\begin{array}{l}0.00 \\
0.00\end{array}$ & $\begin{array}{l}0.00 \\
0.00\end{array}$ & $\begin{array}{l}0.00 \\
0.00\end{array}$ & $\begin{array}{l}0.00 \\
0.00\end{array}$ & $\begin{array}{l}0.00 \\
0.00\end{array}$ & $\begin{array}{l}0.00 \\
0.00\end{array}$ & $\begin{array}{l}0.00 \\
0.00\end{array}$ & $\begin{array}{l}0.00 \\
0.00\end{array}$ & 0.00 \\
\hline SWITZERL. & $\begin{array}{r}-30.71 \\
0.00\end{array}$ & $\begin{array}{l}0.00 \\
0.00\end{array}$ & $\begin{array}{r}247.39 \\
93.74\end{array}$ & $\begin{array}{r}-1463.59 \\
39.07\end{array}$ & $\begin{array}{l}0.00 \\
0.00\end{array}$ & $\begin{array}{l}0.00 \\
0.00\end{array}$ & $\begin{array}{l}-2.94 \\
20.89\end{array}$ & $\begin{array}{l}0.00 \\
0.00\end{array}$ & $\begin{array}{l}0.00 \\
0.00\end{array}$ & 0.97 \\
\hline U.K. & $\begin{array}{r}253.54 \\
0.00\end{array}$ & $\begin{array}{l}0.00 \\
0.00\end{array}$ & $\begin{array}{r}238.40 \\
94.89\end{array}$ & $\begin{array}{l}0.00 \\
0.00\end{array}$ & $\begin{array}{l}0.00 \\
0.00\end{array}$ & $\begin{array}{l}0.00 \\
0.00\end{array}$ & $\begin{array}{l}-1.65 \\
12.79\end{array}$ & $\begin{array}{l}0.00 \\
0.00\end{array}$ & $\begin{array}{l}0.00 \\
0.00\end{array}$ & 0.94 \\
\hline CANADA & $\begin{array}{r}785.83 \\
0.00\end{array}$ & $\begin{array}{l}0.00 \\
0.00\end{array}$ & $\begin{array}{r}134.98 \\
19.85\end{array}$ & $\begin{array}{r}-780.98 \\
13.87\end{array}$ & $\begin{array}{l}0.00 \\
0.00\end{array}$ & $\begin{array}{l}0.00 \\
0.00\end{array}$ & $\begin{array}{l}0.00 \\
0.00\end{array}$ & $\begin{array}{l}0.00 \\
0.00\end{array}$ & $\begin{array}{l}0.00 \\
0.00\end{array}$ & 0.83 \\
\hline U.S. & $\begin{array}{r}564.54 \\
0.00\end{array}$ & $\begin{array}{l}0.00 \\
0.00\end{array}$ & $\begin{array}{r}171.59 \\
10.77\end{array}$ & $\begin{array}{r}-674.81 \\
2.11\end{array}$ & $\begin{array}{l}0.00 \\
0.00\end{array}$ & $\begin{array}{l}0.00 \\
0.00\end{array}$ & $\begin{array}{l}0.00 \\
0.00\end{array}$ & $\begin{array}{l}0.00 \\
0.00\end{array}$ & $\begin{array}{l}0.00 \\
0.00\end{array}$ & 0.69 \\
\hline
\end{tabular}


following form for model I.4:

$D(t)=a(0)+a(1) \cdot G(t-1)+a(3) \cdot g+a(5) \cdot P(t-1)+a(7) \cdot p+a(8) \cdot N(t)$

The results of the stepwise regression of $D(t)$ on the explanatory variables in model I.4 are displayed in table III .8.

Model I. 5: Model I.3 with D $(t-1)$ Removed

An examination of table III.7 reveals that $D(t-1)$ has coefficients for only four out of the fifteen OECD countries. It was decided to remove it and to study the resulting effects on the parameter estimates. Model 1.5 has the following form:

$D(t)=a(0)+a(1) \cdot G(t-1)+a(3) \cdot g+a(5) \cdot P(t-1)+a(7) \cdot p$

Table III.9 contains the regression coefficients of model I.5.

The elasticities of demand with respect to the current and the lagged prices and per capita GNP were then calculatéd using formulae 2.7, 2.8, 2.15 and 2.16. The results were as follows:

\section{THE P $(t)$ ELASTICITY OF DEMAND}

\section{Results of Model I}

The elasticities of demand intensity with respect to current prices, $E(D(t), P(t))$, were calculated for the OECD 
TABLE III.7

REGRESSION COEFFICIENTS FOK MOLEL I.3

\begin{tabular}{|c|c|c|c|c|c|c|c|c|c|c|}
\hline & $a(0)$ & $a(1)$ & $a(z)$ & $a(3)$ & $a(4)$ & $a(5)$ & $a(6)$ & $a(7)$ & $a(8)$ & R-saf \\
\hline AUSTRIA & $\begin{array}{r}357.59 \\
0.00\end{array}$ & $\begin{array}{r}233.51 \\
37.48\end{array}$ & $\begin{array}{l}0.00 \\
0.00\end{array}$ & $\begin{array}{l}0.00 \\
0.00\end{array}$ & $\begin{array}{l}0.00 \\
0.00\end{array}$ & $\begin{array}{r}-2.29 \\
8.02\end{array}$ & $\begin{array}{l}0.00 \\
0.00\end{array}$ & $\begin{array}{l}0.00 \\
0.00\end{array}$ & $\begin{array}{l}0.00 \\
0.00\end{array}$ & 0.85 \\
\hline BELGIUM & $\begin{array}{r}305.36 \\
0.00\end{array}$ & $\begin{array}{r}124.48 \\
47.62\end{array}$ & $\begin{array}{l}0.00 \\
0.00\end{array}$ & $\begin{array}{r}318.98 \\
3.58\end{array}$ & $\begin{array}{l}0.00 \\
0.00\end{array}$ & $\begin{array}{l}0.00 \\
0.00\end{array}$ & $\begin{array}{l}0.00 \\
0.00\end{array}$ & $\begin{array}{r}-2.09 \\
23.18\end{array}$ & $\begin{array}{l}0.00 \\
0.00\end{array}$ & 0.89 \\
\hline DENMARK & $\begin{array}{r}788.44 \\
0.00\end{array}$ & $\begin{array}{r}-51.41 \\
17.45\end{array}$ & $\begin{array}{l}0.00 \\
0.00\end{array}$ & $\begin{array}{l}0.00 \\
0.00\end{array}$ & $\begin{array}{l}0.00 \\
0.00\end{array}$ & $\begin{array}{l}0.00 \\
0.00\end{array}$ & $\begin{array}{l}0.00 \\
0.00\end{array}$ & $\begin{array}{r}-1.06 \\
7.00\end{array}$ & $\begin{array}{l}0.00 \\
0.00\end{array}$ & 0.87 \\
\hline GERMANY & $\begin{array}{r}147.66 \\
0.00\end{array}$ & $\begin{array}{r}135.89 \\
20.10\end{array}$ & $\begin{array}{l}0.00 \\
0.00\end{array}$ & $\begin{array}{l}0.00 \\
0.00\end{array}$ & $\begin{array}{l}0.00 \\
0.00\end{array}$ & $\begin{array}{l}0.00 \\
0.00\end{array}$ & $\begin{array}{l}0.00 \\
0.00\end{array}$ & $\begin{array}{r}-0.75 \\
1.80\end{array}$ & $\begin{array}{l}0.00 \\
0.00\end{array}$ & 0.83 \\
\hline ITALY & $\begin{array}{r}319.63 \\
0.00\end{array}$ & $\begin{array}{r}283.88 \\
69.62\end{array}$ & $\begin{array}{l}0.00 \\
0.00\end{array}$ & $\begin{array}{l}0.00 \\
0.00\end{array}$ & $\begin{array}{l}0.00 \\
0.00\end{array}$ & $\begin{array}{l}0.00 \\
0.00\end{array}$ & $\begin{array}{l}0.00 \\
0.00\end{array}$ & $\begin{array}{l}-2.38 \\
17.97\end{array}$ & $\begin{array}{l}0.00 \\
0.00\end{array}$ & 0.92 \\
\hline LUXEMBOUKG & $\begin{array}{r}-221.04 \\
0.00\end{array}$ & $\begin{array}{r}282.80 \\
28.50\end{array}$ & $\begin{array}{l}0.00 \\
0.00\end{array}$ & $\begin{array}{r}-775.65 \\
3.79\end{array}$ & $\begin{array}{l}0.00 \\
0.00\end{array}$ & $\begin{array}{l}0.00 \\
0.00\end{array}$ & $\begin{array}{l}0.00 \\
0.00\end{array}$ & $\begin{array}{l}0.00 \\
0.00\end{array}$ & $\begin{array}{l}0.00 \\
0.00\end{array}$ & 0.88 \\
\hline NETHERL. & $\begin{array}{r}696.33 \\
0.00\end{array}$ & $\begin{array}{r}234.10 \\
9.86\end{array}$ & $\begin{array}{l}0.00 \\
0.00\end{array}$ & $\begin{array}{l}0.00 \\
0.00\end{array}$ & $\begin{array}{r}-0.96 \\
3.75\end{array}$ & $\begin{array}{l}-3.15 \\
12.27\end{array}$ & $\begin{array}{l}0.00 \\
0.00\end{array}$ & $\begin{array}{l}0.00 \\
0.00\end{array}$ & $\begin{array}{l}0.00 \\
0.00\end{array}$ & 0.80 \\
\hline NOFWAY & $\begin{array}{r}259.12 \\
0.00\end{array}$ & $\begin{array}{r}113.68 \\
75.73\end{array}$ & $\begin{array}{l}0.00 \\
0.00\end{array}$ & $\begin{array}{r}1114.99 \\
5.09\end{array}$ & $\begin{array}{l}0.00 \\
0.00\end{array}$ & $\begin{array}{l}0.00 \\
0.00\end{array}$ & $\begin{array}{l}0.00 \\
0.00\end{array}$ & $\begin{array}{l}-2.13 \\
45.88\end{array}$ & $\begin{array}{l}0.00 \\
0.00\end{array}$ & 0.93 \\
\hline
\end{tabular}


TABLE III.7 CONTI.

FEGRESSION COEFFICIENTS FOF MOUEL I.3

\begin{tabular}{|c|c|c|c|c|c|c|c|c|c|c|}
\hline & $a(0)$ & $a(1)$ & $a(2)$ & $a(3)$ & $a(4)$ & $3(5)$ & $a(6)$ & $a(7)$ & $(8)$ & $R-S Q R$ \\
\hline PORTUGAL & $\begin{array}{r}-113.62 \\
0.00\end{array}$ & $\begin{array}{l}604.72 \\
187.09\end{array}$ & $\begin{array}{l}0.00 \\
0.00\end{array}$ & $\begin{array}{l}0.00 \\
0.00\end{array}$ & $\begin{array}{l}0.00 \\
0.00\end{array}$ & $\begin{array}{r}5.03 \\
50.08\end{array}$ & $\begin{array}{l}0.00 \\
0.00\end{array}$ & $\begin{array}{l}-3.27 \\
38.94\end{array}$ & $\begin{array}{l}0.00 \\
0.00\end{array}$ & 0.98 \\
\hline SPAIN & $\begin{array}{r}139.82 \\
0.00\end{array}$ & $\begin{array}{r}335.97 \\
23.16\end{array}$ & $\begin{array}{l}0.00 \\
0.00\end{array}$ & $\begin{array}{l}0.26 \\
3.24\end{array}$ & $\begin{array}{l}0.00 \\
0.00\end{array}$ & $\begin{array}{r}1 . \overline{38} \\
17.68\end{array}$ & $\begin{array}{l}0.00 \\
0.00\end{array}$ & $\begin{array}{l}-1.33 \\
86.47\end{array}$ & $\begin{array}{l}0.00 \\
0.00\end{array}$ & 0.99 \\
\hline SWEDEN & $\begin{array}{r}1246.02 \\
0.00\end{array}$ & $\begin{array}{l}46.78 \\
20.78\end{array}$ & $\begin{array}{l}0.00 \\
0.00\end{array}$ & $\begin{array}{r}570.96 \\
9.45\end{array}$ & $\begin{array}{l}-1.66 \\
48.06\end{array}$ & $\begin{array}{l}-4.62 \\
47.27\end{array}$ & $\begin{array}{l}0.00 \\
0.00\end{array}$ & $\begin{array}{r}2.40 \\
15.65\end{array}$ & $\begin{array}{l}0.00 \\
0.00\end{array}$ & 0.95 \\
\hline SHITZERL. & $\begin{array}{r}-48.27 \\
0.00\end{array}$ & $\begin{array}{l}252.40 \\
100.64\end{array}$ & $\begin{array}{l}0.00 \\
0.00\end{array}$ & $\begin{array}{r}-581.57 \\
11.74\end{array}$ & $\begin{array}{l}0.00 \\
0.00\end{array}$ & $\begin{array}{l}0.00 \\
0.00\end{array}$ & $\begin{array}{l}0.00 \\
0.00\end{array}$ & $\begin{array}{l}-2.95 \\
22.54\end{array}$ & $\begin{array}{l}0.00 \\
0.00\end{array}$ & 0.97 \\
\hline U.K. & $\begin{array}{r}250.35 \\
0.00\end{array}$ & $\begin{array}{l}0.00 \\
0.00\end{array}$ & $\begin{array}{l}0.00 \\
0.00\end{array}$ & $\begin{array}{l}0.00 \\
0.00\end{array}$ & $\begin{array}{r}0.77 \\
268.53\end{array}$ & $\begin{array}{l}0.00 \\
0.00\end{array}$ & $\begin{array}{l}0.00 \\
0.00\end{array}$ & $\begin{array}{l}-1.26 \\
20.15\end{array}$ & $\begin{array}{l}0.00 \\
0.00\end{array}$ & 0.98 \\
\hline CANADA & $\begin{array}{r}693.97 \\
0.00\end{array}$ & $\begin{array}{r}155.81 \\
30.58\end{array}$ & $\begin{array}{l}0.00 \\
0.00\end{array}$ & $\begin{array}{l}0.00 \\
0.00\end{array}$ & $\begin{array}{l}0.00 \\
0.00\end{array}$ & $\begin{array}{l}0.00 \\
0.00\end{array}$ & $\begin{array}{l}0.00 \\
0.00\end{array}$ & $\begin{array}{l}0.00 \\
0.00\end{array}$ & $\begin{array}{l}0.00 \\
0.00\end{array}$ & 0.79 \\
\hline U.S. & $\begin{array}{r}71.37 \\
0.00\end{array}$ & $\begin{array}{l}0.00 \\
0.00\end{array}$ & $\begin{array}{l}0.00 \\
0.00\end{array}$ & $\begin{array}{l}0.00 \\
0.00\end{array}$ & $\begin{array}{r}0.96 \\
30.58\end{array}$ & $\begin{array}{l}0.00 \\
0.00\end{array}$ & $\begin{array}{l}0.00 \\
0.00\end{array}$ & $\begin{array}{l}0.00 \\
0.00\end{array}$ & $\begin{array}{l}0.00 \\
0.00\end{array}$ & 0.75 \\
\hline
\end{tabular}


TAB̈LE III. 6

REGRESSION COEFFICIENTS FOR MODEL I.4

\begin{tabular}{|c|c|c|c|c|c|c|c|c|c|c|}
\hline & $a(0)$ & $a(1)$ & $a(2)$ & $a(3)$ & $a(4)$ & $a(5)$ & $a(6)$ & $a(7)$ & $a(8)$ & R-SQR \\
\hline AUSTRIA & $\begin{array}{r}496.43 \\
0.00\end{array}$ & $\begin{array}{l}0.00 \\
0.00\end{array}$ & $\begin{array}{l}0.00 \\
0.00\end{array}$ & $\begin{array}{l}0.00 \\
0.00\end{array}$ & $\begin{array}{l}0.00 \\
0.00\end{array}$ & $\begin{array}{l}-2.30 \\
12.53\end{array}$ & $\begin{array}{l}0.00 \\
0.00\end{array}$ & $\begin{array}{l}0.00 \\
0.00\end{array}$ & $\begin{array}{r}210.80 \\
60.69\end{array}$ & 0.90 \\
\hline BELGIUM & $\begin{array}{r}407.10 \\
0.00\end{array}$ & $\begin{array}{l}0.00 \\
0.00\end{array}$ & $\begin{array}{l}0.00 \\
0.00\end{array}$ & $\begin{array}{l}0.00 \\
0.00\end{array}$ & $\begin{array}{l}0.00 \\
0.00\end{array}$ & $\begin{array}{r}-1.94 \\
42.15\end{array}$ & $\begin{array}{l}0.00 \\
0.00\end{array}$ & $\begin{array}{r}-87.59 \\
13.58\end{array}$ & $\begin{array}{r}94.46 \\
111.57\end{array}$ & 0.95 \\
\hline DENMAFK & $\begin{array}{r}1023.00 \\
0.00\end{array}$ & $\begin{array}{r}-222.73 \\
23.16\end{array}$ & $\begin{array}{l}0.00 \\
0.00\end{array}$ & $\begin{array}{r}-530.75 \\
5.25\end{array}$ & $\begin{array}{l}0.00 \\
0.00\end{array}$ & $\begin{array}{l}-2.18 \\
14.91\end{array}$ & $\begin{array}{l}0.00 \\
0.00\end{array}$ & $\begin{array}{l}0.00 \\
0.00\end{array}$ & $\begin{array}{l}23.80 \\
12.50\end{array}$ & 0.95 \\
\hline GERHANY & $\begin{array}{r}465.44 \\
0.00\end{array}$ & $\begin{array}{r}-86.74 \\
8.17\end{array}$ & $\begin{array}{l}0.00 \\
0.00\end{array}$ & $\begin{array}{r}-419.00 \\
30.64\end{array}$ & $\begin{array}{l}0.00 \\
0.00\end{array}$ & $\begin{array}{l}-1.07 \\
33.01\end{array}$ & $\begin{array}{l}0.00 \\
0.00\end{array}$ & $\begin{array}{l}0.00 \\
0.00\end{array}$ & $\begin{array}{l}23.80 \\
51.54\end{array}$ & 0.98 \\
\hline ITALY & $\begin{array}{r}698.67 \\
0.00\end{array}$ & $\begin{array}{l}0.00 \\
0.00\end{array}$ & $\begin{array}{l}0.00 \\
0.00\end{array}$ & $\begin{array}{r}-419.56 \\
2.94\end{array}$ & $\begin{array}{l}0.00 \\
0.00\end{array}$ & $\begin{array}{l}-3.59 \\
12.42\end{array}$ & $\begin{array}{l}0.00 \\
0.00\end{array}$ & $\begin{array}{r}-239.83 \\
28.63\end{array}$ & $\begin{array}{l}18.06 \\
62.94\end{array}$ & 0.96 \\
\hline LUXEMBOURG & $\begin{array}{r}-221.00 \\
0.00\end{array}$ & $\begin{array}{r}282.80 \\
28.49\end{array}$ & $\begin{array}{l}0.00 \\
0.00\end{array}$ & $\begin{array}{r}-775.70 \\
3.79\end{array}$ & $\begin{array}{l}0.00 \\
0.00\end{array}$ & $\begin{array}{l}0.00 \\
0.00\end{array}$ & $\begin{array}{l}0.00 \\
0.00\end{array}$ & $\begin{array}{l}0.00 \\
0.00\end{array}$ & $\begin{array}{l}0.00 \\
0.00\end{array}$ & 0.88 \\
\hline NETHERL. & $\begin{array}{r}1108.30 \\
0.00\end{array}$ & $\begin{array}{r}-319.97 \\
41.23\end{array}$ & $\begin{array}{l}0.00 \\
0.00\end{array}$ & $\begin{array}{r}-652.90 \\
20.75\end{array}$ & $\begin{array}{l}0.00 \\
0.00\end{array}$ & $\begin{array}{r}-3.51 \\
149.74\end{array}$ & $\begin{array}{l}0.00 \\
0.00\end{array}$ & $\begin{array}{r}75.29 \\
7.12\end{array}$ & $\begin{array}{r}154.10 \\
78.67\end{array}$ & .0 .98 \\
\hline NORWAY & $\begin{array}{r}319.52 \\
0.00\end{array}$ & $\begin{array}{l}0.00 \\
0.00\end{array}$ & $\begin{array}{l}0.00 \\
0.00\end{array}$ & $\begin{array}{r}1164.10 \\
3.47\end{array}$ & $\begin{array}{l}0.00 \\
0.00\end{array}$ & $\begin{array}{l}-1.23 \\
14.70\end{array}$ & $\begin{array}{l}0.00 \\
0.00\end{array}$ & $\begin{array}{r}-116.09 \\
30.11\end{array}$ & $\begin{array}{r}208.92 \\
74.17\end{array}$ & 0.95 \\
\hline
\end{tabular}


TABLE III.8 CONTD.

REGRESSION COEFFICIENTS FOR MODEL I.4

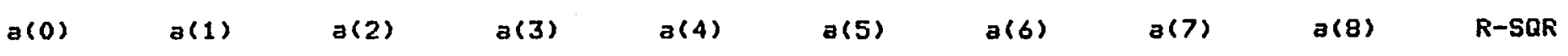

\begin{tabular}{|c|c|c|c|c|c|c|c|c|c|c|}
\hline PORTUGAL & $\begin{array}{r}225.80 \\
0.00\end{array}$ & $\begin{array}{r}234.33 \\
7.47\end{array}$ & $\begin{array}{l}0.00 \\
0.00\end{array}$ & $\begin{array}{r}-145 \cdot 20 \\
7.10\end{array}$ & $\begin{array}{l}0.00 \\
0.00\end{array}$ & $\begin{array}{l}0.00 \\
0.00\end{array}$ & $\begin{array}{l}0.00 \\
0.00\end{array}$ & $\begin{array}{r}-238.50 \\
114.14\end{array}$ & $\begin{array}{r}109.81 \\
6.03\end{array}$ & 0.99 \\
\hline SPAIN & $\begin{array}{r}349.06 \\
0.00\end{array}$ & $\begin{array}{r}135.43 \\
2.10\end{array}$ & $\begin{array}{l}0.00 \\
0.00\end{array}$ & $\begin{array}{l}0.00 \\
0.00\end{array}$ & $\begin{array}{l}0.00 \\
0.00\end{array}$ & $\begin{array}{r}-3.01 \\
677.47\end{array}$ & $\begin{array}{l}0.00 \\
0.00\end{array}$ & $\begin{array}{r}-78.96 \\
90.97\end{array}$ & $\begin{array}{l}38.11 \\
12.55\end{array}$ & 0.99 \\
\hline SWEDEN & $\begin{array}{r}835.89 \\
0.00\end{array}$ & $\begin{array}{r}-177.74 \\
4.91\end{array}$ & $\begin{array}{l}0.00 \\
0.00\end{array}$ & $\begin{array}{r}-397.02 \\
2.12\end{array}$ & $\begin{array}{l}0.00 \\
0.00\end{array}$ & $\begin{array}{r}-2.34 \\
7.65\end{array}$ & $\begin{array}{l}0.00 \\
0.00\end{array}$ & $\begin{array}{l}0.00 \\
0.00\end{array}$ & $\begin{array}{r}216.42 \\
6.63\end{array}$ & 0.70 \\
\hline SWITZERL. & $\begin{array}{r}113.36 \\
0.00\end{array}$ & $\begin{array}{l}215.24 \\
286.84\end{array}$ & $\begin{array}{l}0.00 \\
0.00\end{array}$ & $\begin{array}{r}-744.20 \\
32.11\end{array}$ & $\begin{array}{l}0.00 \\
0.00\end{array}$ & $\begin{array}{l}-3.75 \\
52.92\end{array}$ & $\begin{array}{l}0.00 \\
0.00\end{array}$ & $\begin{array}{l}0.00 \\
0.00\end{array}$ & $\begin{array}{l}0.00 \\
0.00\end{array}$ & 0.94 \\
\hline U.K. & $\begin{array}{r}613.56 \\
0.00\end{array}$ & $\begin{array}{l}0.00 \\
0.00\end{array}$ & $\begin{array}{l}0.00 \\
0.00\end{array}$ & $\begin{array}{l}0.00 \\
0.00\end{array}$ & $\begin{array}{l}0.00 \\
0.00\end{array}$ & $\begin{array}{r}-3.07 \\
149.08\end{array}$ & $\begin{array}{l}0.00 \\
0.00\end{array}$ & $\begin{array}{r}-71.45 \\
26.13\end{array}$ & $\begin{array}{r}19.01 \\
378.70\end{array}$ & 0.98 \\
\hline CANADA & $\begin{array}{r}1923.71 \\
0.00\end{array}$ & $\begin{array}{r}-118.75 \\
2.31\end{array}$ & $\begin{array}{l}0.00 \\
0.00\end{array}$ & $\begin{array}{r}-877.78 \\
15.98\end{array}$ & $\begin{array}{l}0.00 \\
0.00\end{array}$ & $\begin{array}{r}-14.94 \\
11.48\end{array}$ & $\begin{array}{l}0.00 \\
0.00\end{array}$ & $\begin{array}{l}0.00 \\
0.00\end{array}$ & $\begin{array}{l}61.19 \\
11.81\end{array}$ & 0.96 \\
\hline U.S. & $\begin{array}{r}2276.25 \\
0.00\end{array}$ & $\begin{array}{r}-196.49 \\
3.93\end{array}$ & $\begin{array}{l}0.00 \\
0.00\end{array}$ & $\begin{array}{r}-1125.63 \\
7.94\end{array}$ & $\begin{array}{l}0.00 \\
0.00\end{array}$ & $\begin{array}{r}-17.28 \\
14.68\end{array}$ & $\begin{array}{l}0.00 \\
0.00\end{array}$ & $\begin{array}{r}-401.52 \\
13.25\end{array}$ & $\begin{array}{r}7.00 \\
16.20\end{array}$ & 0.96 \\
\hline
\end{tabular}


TABLE III.9

REGRESSION COEFPICIENTS FOR MODEL I.5

$\begin{array}{llllllllll}a(0) & 3(1) & 3(2) & a(3) & a(4) & 3(5) & a(6) & a(7) & a(8) & R-5(R R\end{array}$

\begin{tabular}{|c|c|c|c|c|c|c|c|c|c|c|}
\hline AUSTRIA & $\begin{array}{r}357.60 \\
0.00\end{array}$ & $\begin{array}{r}233.51 \\
37.48\end{array}$ & $\begin{array}{l}0.00 \\
0.00\end{array}$ & $\begin{array}{l}0.00 \\
0.00\end{array}$ & $\begin{array}{l}0.00 \\
0.00\end{array}$ & $\begin{array}{r}-2.30 \\
8.02\end{array}$ & $\begin{array}{l}0.00 \\
0.00\end{array}$ & $\begin{array}{l}0.00 \\
0.00\end{array}$ & $\begin{array}{l}0.00 \\
0.00\end{array}$ & 0.85 \\
\hline BELGIUM & $\begin{array}{r}327.85 \\
0.00\end{array}$ & $\begin{array}{r}130.33 \\
27.95\end{array}$ & $\begin{array}{l}0.00 \\
0.00\end{array}$ & $\begin{array}{l}0.00 \\
0.00\end{array}$ & $\begin{array}{l}0.00 \\
0.00\end{array}$ & $\begin{array}{l}-2.39 \\
13.63\end{array}$ & $\begin{array}{l}0.00 \\
0.00\end{array}$ & $\begin{array}{r}-146.93 \\
8.49\end{array}$ & $\begin{array}{l}0.00 \\
0.00\end{array}$ & 0.83 \\
\hline DENMARK & $\begin{array}{r}808.27 \\
0.00\end{array}$ & $\begin{array}{r}-64.69 \\
26.76\end{array}$ & $\begin{array}{l}0.00 \\
0.00\end{array}$ & $\begin{array}{l}0.00 \\
0.00\end{array}$ & $\begin{array}{l}0.00 \\
0.00\end{array}$ & $\begin{array}{r}-7.92 \\
3.40\end{array}$ & $\begin{array}{l}0.00 \\
0.00\end{array}$ & $\begin{array}{l}0.00 \\
0.00\end{array}$ & $\begin{array}{l}0.00 \\
0.00\end{array}$ & 0.83 \\
\hline GERMANY & $\begin{array}{r}205.89 \\
0.00\end{array}$ & $\begin{array}{r}123.00 \\
23.89\end{array}$ & $\begin{array}{l}0.00 \\
0.00\end{array}$ & $\begin{array}{r}-339.09 \\
2.18\end{array}$ & $\begin{array}{l}0.00 \\
0.00\end{array}$ & $\begin{array}{r}-0.92 \\
2.62\end{array}$ & $\begin{array}{l}0.00 \\
0.00\end{array}$ & $\begin{array}{l}0.00 \\
0.00\end{array}$ & $\begin{array}{l}0.00 \\
0.00\end{array}$ & 0.86 \\
\hline ITALY & $\begin{array}{r}288.90 \\
0.00\end{array}$ & $\begin{array}{r}273.54 \\
40.96\end{array}$ & $\begin{array}{l}0.00 \\
0.00\end{array}$ & $\begin{array}{l}0.00 \\
0.00\end{array}$ & $\begin{array}{l}0.00 \\
0.00\end{array}$ & $\begin{array}{r}-1.82 \\
4.94\end{array}$ & $\begin{array}{l}0.00 \\
0.00\end{array}$ & $\begin{array}{r}-195.79 \\
16.75\end{array}$ & $\begin{array}{l}0.00 \\
0.00\end{array}$ & 0.93 \\
\hline LUXEMBOURG & $\begin{array}{r}-221.04 \\
0.00\end{array}$ & $\begin{array}{r}282.79 \\
28.49\end{array}$ & $\begin{array}{l}0.00 \\
0.00\end{array}$ & $\begin{array}{r}-775.65 \\
3.79\end{array}$ & $\begin{array}{l}0.00 \\
0.00\end{array}$ & $\begin{array}{l}0.00 \\
0.00\end{array}$ & $\begin{array}{l}0.00 \\
0.00\end{array}$ & $\begin{array}{l}0.00 \\
0.00\end{array}$ & $\begin{array}{l}0.00 \\
0.00\end{array}$ & 0.88 \\
\hline NETHERL. & $\begin{array}{r}440.20 \\
0.00\end{array}$ & $\begin{array}{r}111.59 \\
7.19\end{array}$ & $\begin{array}{l}0.00 \\
0.00\end{array}$ & $\begin{array}{l}0.00 \\
0.00\end{array}$ & $\begin{array}{l}0.00 \\
0.00\end{array}$ & $\begin{array}{r}-2.27 \\
8.17\end{array}$ & $\begin{array}{l}0.00 \\
0.00\end{array}$ & $\begin{array}{l}0.00 \\
0.00\end{array}$ & $\begin{array}{l}0.00 \\
0.00\end{array}$ & 0.65 \\
\hline NORWAY & $\begin{array}{r}299.78 \\
0.00\end{array}$ & $\begin{array}{r}103.61 \\
39.18\end{array}$ & $\begin{array}{l}0.00 \\
0.00\end{array}$ & $\begin{array}{l}0.00 \\
0.00\end{array}$ & $\begin{array}{l}0.00 \\
0.00\end{array}$ & $\begin{array}{r}-1.74 \\
13.88\end{array}$ & $\begin{array}{l}0.00 \\
0.00\end{array}$ & $\begin{array}{r}-121.85 \\
24.56\end{array}$ & $\begin{array}{l}0.00 \\
0.00\end{array}$ & 0.88 \\
\hline
\end{tabular}


TABLE III. 9 CONTD.

REGRESSION COEFFICIENTS FOR MODEL I.5

\begin{tabular}{|c|c|c|c|c|c|c|c|c|c|c|}
\hline & $a(0)$ & $a(1)$ & $3(2)$ & $a(3)$ & $a(4)$ & $a(5)$ & $(6)$ & $a(7)$ & $a(8)$ & R-SQR \\
\hline FORTUGAL & $\begin{array}{r}164.79 \\
0.00\end{array}$ & $\begin{array}{l}441.27 \\
420.10\end{array}$ & $\begin{array}{l}0.00 \\
0.00\end{array}$ & $\begin{array}{r}-244.10 \\
24.09\end{array}$ & $\begin{array}{l}0.00 \\
0.00\end{array}$ & $\begin{array}{l}0.00 \\
0.00\end{array}$ & $\begin{array}{l}0.00 \\
0.00\end{array}$ & $\begin{array}{r}-265.04 \\
100.14\end{array}$ & $\begin{array}{l}0.00 \\
0.00\end{array}$ & 0.99 \\
\hline SPAIN & $\begin{array}{r}110.36 \\
0.00\end{array}$ & $\begin{array}{r}477.28 \\
4088.19\end{array}$ & $\begin{array}{l}0.00 \\
0.00\end{array}$ & $\begin{array}{r}167.90 \\
5.83\end{array}$ & $\begin{array}{l}0.00 \\
.0 .00\end{array}$ & $\begin{array}{r}-3.11 \\
545.39\end{array}$ & $\begin{array}{l}0.00 \\
0.00\end{array}$ & $\begin{array}{l}107.06 \\
107.18\end{array}$ & $\begin{array}{l}0.00 \\
0.00\end{array}$ & 0.99 \\
\hline SWEDEN & $\begin{array}{l}0.00 \\
0.00\end{array}$ & $\begin{array}{l}0.00 \\
0.00\end{array}$ & $\begin{array}{l}0.00 \\
0.00\end{array}$ & $\begin{array}{l}0.00 \\
0.00\end{array}$ & $\begin{array}{l}0.00 \\
0.00\end{array}$ & $\begin{array}{l}0.00 \\
0.00\end{array}$ & $\begin{array}{l}0.00 \\
0.00\end{array}$ & $\begin{array}{l}0.00 \\
0.00\end{array}$ & $\begin{array}{l}0.00 \\
0.00\end{array}$ & 0.00 \\
\hline SHITZERL. & $\begin{array}{r}113.36 \\
0.00\end{array}$ & $\begin{array}{l}215.23 \\
286.84\end{array}$ & $\begin{array}{l}0.00 \\
0.00\end{array}$ & $\begin{array}{r}-744.20 \\
32.11\end{array}$ & $\begin{array}{l}0.00 \\
0.00\end{array}$ & $\begin{array}{l}-3.75 \\
52.92\end{array}$ & $\begin{array}{l}0.00 \\
0.00\end{array}$ & $\begin{array}{l}0.00 \\
0.00\end{array}$ & $\begin{array}{l}0.00 \\
0.00\end{array}$ & 0.98 \\
\hline U.K. & $\begin{array}{r}388.60 \\
0.00\end{array}$ & $\begin{array}{l}224.96 \\
147.34\end{array}$ & $\begin{array}{l}0.00 \\
0.00\end{array}$ & $\begin{array}{l}0.00 \\
0.00\end{array}$ & $\begin{array}{l}0.00 \\
0.00\end{array}$ & $\begin{array}{l}-3.05 \\
26.29\end{array}$ & $\begin{array}{l}0.00 \\
0.00\end{array}$ & $\begin{array}{r}-118.87 \\
24.73\end{array}$ & $\begin{array}{l}0.00 \\
0.00\end{array}$ & 0.98 \\
\hline CANADA & $\begin{array}{r}693.97 \\
0.00\end{array}$ & $\begin{array}{r}155.81 \\
30.58\end{array}$ & $\begin{array}{l}0.00 \\
0.00\end{array}$ & $\begin{array}{l}0.00 \\
0.00\end{array}$ & $\begin{array}{l}0.00 \\
0.00\end{array}$ & $\begin{array}{l}0.00 \\
0.00\end{array}$ & $\begin{array}{l}0.00 \\
0.00\end{array}$ & $\begin{array}{l}0.00 \\
0.00\end{array}$ & $\begin{array}{l}0.00 \\
0.00\end{array}$ & 0.79 \\
\hline U.S. & $\begin{array}{r}600.00 \\
0.00\end{array}$ & $\begin{array}{r}164.65 \\
16.79\end{array}$ & $\begin{array}{l}0.00 \\
0.00\end{array}$ & $\begin{array}{l}0.00 \\
0.00\end{array}$ & $\begin{array}{l}0.00 \\
0.00\end{array}$ & $\begin{array}{l}0.00 \\
0.00\end{array}$ & $\begin{array}{l}0.00 \\
0.00\end{array}$ & $\begin{array}{l}0.00 \\
0.00\end{array}$ & $\begin{array}{l}0.00 \\
0.00\end{array}$ & 0.68 \\
\hline
\end{tabular}


countries for the various years. The results are displayed in table III.10. It can be seen from the table that the elasticity coefficients vary over a wide range for the different countries, which makes intercountry comparisons nonmeaningful. The difficulty of intercountry comparisons, as far as demand elasticities are concerned, has been concluded by several researchers for various commodities (see e.g. Bridge, 1971, p. 129).

By introducing the ratio of price to per capita GNP; P.F.: as a parameter, a distinct pattern emerges for the elasticity behavior in different countries.

A main contribution of this thesis is the introduction of P.F. as a parameter, which establishes a basis for intercountry comparlsons.

It may be observed, for example, that the highest elasticity values (largest negative values) appear for Portugal which has the highest values of $P . F .$, while price elasticities of zero are associated with the lowest P.F. values in the U.S. and canada. The elasticity pattern as a function of P.F. shows some anomalies, yet, when the elasticity values were averaged over countries, the resulting behavior appeared quite reasonable from an economic-theoretic point of view.

The range of $P . F$. was subdivided into 5-unit intervals, and the price elasticity values were averaged over the various countries for each interval of $P . F$.

Table III.11 displays the average elasticities of 
TABLE III.10

VARIOUS ELASTICITIES OF DEMAND: MODEL I

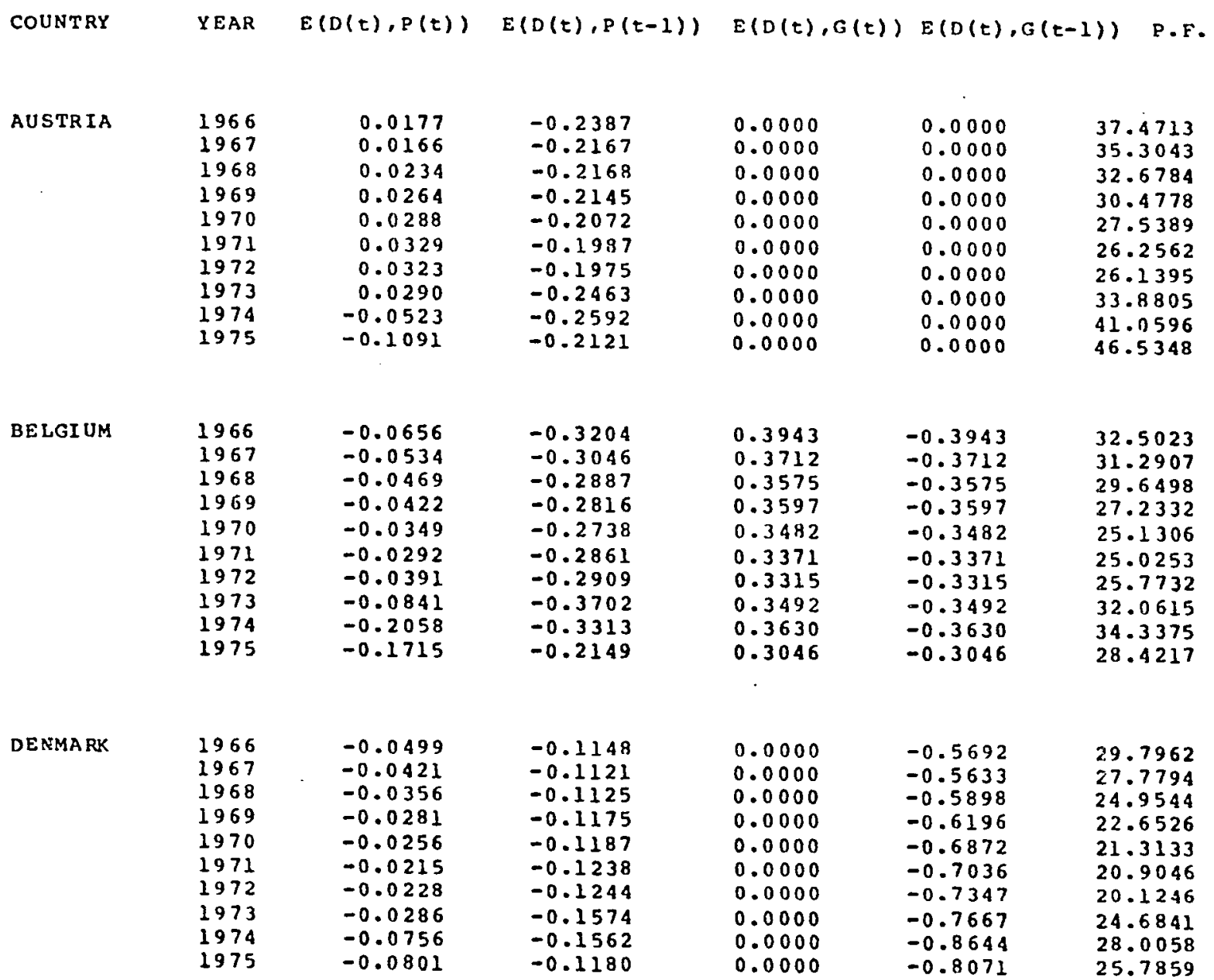


TABLE III.10 CONTD.

VARIOUS ELASTICITIES OF OEMAND: MODEL I

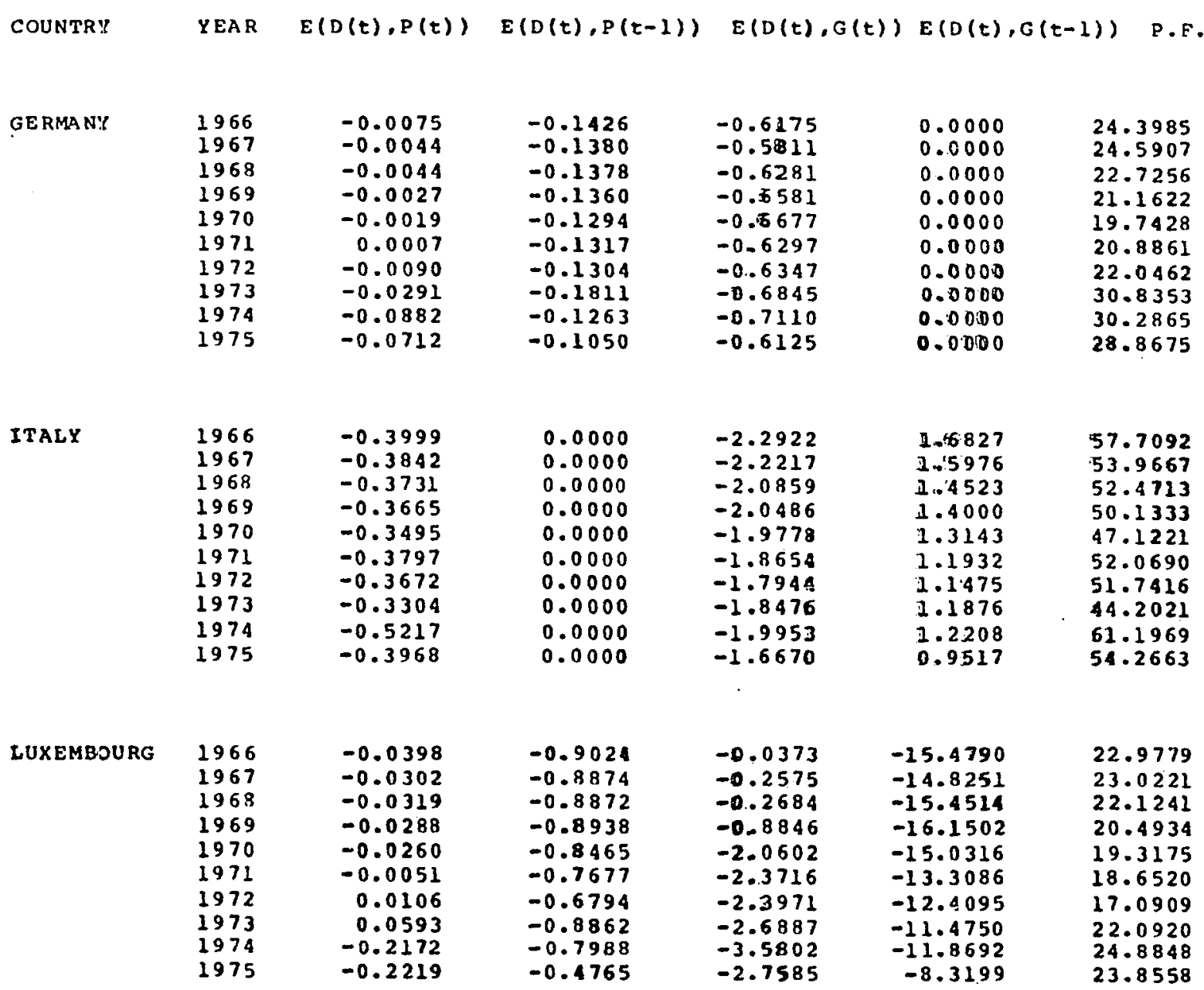


TABLE III.10 CONTD.

VARIOUS ELASTICITIES OF DEMAND: MODEL I

\begin{tabular}{|c|c|c|c|c|c|c|}
\hline COUNTRY & YEAR & $E(D(t), P(t))$ & $E(D(t), P(t-1))$ & $E(D(\tau), G(\tau))$ & $E(D(t)$, & P.F. \\
\hline NETHERL. & $\begin{array}{l}1966 \\
1967 \\
1968 \\
1969 \\
1970 \\
1971 \\
1972 \\
1973 \\
1974 \\
1975\end{array}$ & $\begin{array}{r}0.1894 \\
0.1965 \\
0.1894 \\
0.1878 \\
0.2030 \\
0.2143 \\
0.2022 \\
0.1690 \\
0.0359 \\
-0.0180\end{array}$ & $\begin{array}{l}-0.6104 \\
-0.6023 \\
-0.5764 \\
-0.5644 \\
-0.5627 \\
-0.5862 \\
-0.6156 \\
-0.6958 \\
-0.6894 \\
-0.5373\end{array}$ & $\begin{array}{l}-0.8282 \\
-0.8370 \\
-0.8457 \\
-0.9059 \\
-0.9130 \\
-0.9216 \\
-0.9335 \\
-0.9982 \\
-1.1525 \\
-1.0314\end{array}$ & $\begin{array}{l}-0.1744 \\
-0.1712 \\
-0.1717 \\
-0.1836 \\
-0.1863 \\
-0.1907 \\
-0.1941 \\
-0.2031 \\
-0.2427 \\
-0.2245\end{array}$ & $\begin{array}{l}32.9950 \\
31.4689 \\
29.7091 \\
26.9871 \\
25.5761 \\
26.2032 \\
28.7442 \\
34.2620 \\
36.8145 \\
34.9556\end{array}$ \\
\hline NORWAY & $\begin{array}{l}1966 \\
1967 \\
1968 \\
1969 \\
1970 \\
1971 \\
1972 \\
1973 \\
1974 \\
1975\end{array}$ & $\begin{array}{l}-0.3810 \\
-0.3700 \\
-0.3627 \\
-0.3477 \\
-0.3253 \\
-0.3308 \\
-0.3441 \\
-0.3158 \\
-0.5475 \\
-0.4963\end{array}$ & $\begin{array}{l}-0.1670 \\
-0.1599 \\
-0.1590 \\
-0.1538 \\
-0.1420 \\
-0.1612 \\
-0.1434 \\
-0.1316 \\
-0.2515 \\
-0.1243\end{array}$ & $\begin{array}{l}3.9449 \\
3.8999 \\
3.8542 \\
3.7135 \\
3.7092 \\
3.5566 \\
3.5646 \\
3.4888 \\
4.0441 \\
3.6606\end{array}$ & $\begin{array}{l}-3.3725 \\
-3.3160 \\
-3.2555 \\
-3.1200 \\
-3.0961 \\
-2.9548 \\
-2.9424 \\
-2.8582 \\
-3.2940 \\
-2.9561\end{array}$ & $\begin{array}{l}29.5221 \\
27.9846 \\
26.8773 \\
26.0571 \\
23.5069 \\
25.2107 \\
24.1635 \\
21.8789 \\
32.8516 \\
27.1676\end{array}$ \\
\hline PORTUGAL & $\begin{array}{l}1966 \\
1967 \\
1968 \\
1969 \\
1970 \\
1971 \\
1972 \\
1973 \\
1974 \\
1975\end{array}$ & $\begin{array}{l}-0.6291 \\
-0.6132 \\
-0.6058 \\
-0.5378 \\
-0.5154 \\
-0.4681 \\
-0.4789 \\
-0.4526 \\
-0.6749 \\
-0.4156\end{array}$ & $\begin{array}{l}0.4754 \\
0.4701 \\
0.4671 \\
0.4158 \\
0.4017 \\
0.3738 \\
0.3941 \\
0.3756 \\
0.5971 \\
0.3315\end{array}$ & $\begin{array}{l}-0.5598 \\
-0.5595 \\
-0.5724 \\
-0.4936 \\
-0.5081 \\
-0.4516 \\
-0.4526 \\
-0.4375 \\
-0.4169 \\
-0.3106\end{array}$ & $\begin{array}{l}0.7768 \\
0.7773 \\
0.8059 \\
0.7290 \\
0.7519 \\
0.6932 \\
0.7065 \\
0.7016 \\
0.7296 \\
0.5635\end{array}$ & $\begin{array}{r}188.7500 \\
170.6964 \\
149.0645 \\
134.0308 \\
112.1831 \\
95.9474 \\
83.7711 \\
71.5217 \\
95.5385 \\
105.4756\end{array}$ \\
\hline
\end{tabular}


TABLE III.10 CONTD.

VARIOUS ELASTICITIES OF DEMAND: MODEL I

\begin{tabular}{|c|c|c|c|c|c|c|}
\hline COUNTRY & YEAR & $E(D(t), P(t))$ & $E(D(t), P(t-1))$ & $E(D(t), G(t))$ & $E(D(t)$, & P.F. \\
\hline SPAIN & $\begin{array}{l}1966 \\
1967 \\
1968 \\
1969 \\
1970 \\
1971 \\
1972 \\
1973 \\
1974 \\
1975\end{array}$ & $\begin{array}{l}-0.3720 \\
-0.2936 \\
-0.2357 \\
-0.2005 \\
-0.1663 \\
-0.1522 \\
-0.1426 \\
-0.1598 \\
-0.2383 \\
-0.2143\end{array}$ & $\begin{array}{l}-0.2152 \\
-0.1911 \\
-0.1747 \\
-0.1658 \\
-0.1468 \\
-0.1539 \\
-0.1358 \\
-0.1638 \\
-0.1694 \\
-0.1073\end{array}$ & $\begin{array}{r}-0.0367 \\
0.0226 \\
0.0451 \\
0.0733 \\
0.1083 \\
0.1356 \\
0.1628 \\
0.2048 \\
0.2560 \\
0.2700\end{array}$ & $\begin{array}{l}0.9288 \\
0.7986 \\
0.7259 \\
0.6831 \\
0.6182 \\
0.5853 \\
0.5651 \\
0.5410 \\
0.5331 \\
0.4927\end{array}$ & $\begin{array}{l}78.4725 \\
70.3617 \\
63.4694 \\
57.7308 \\
51.3761 \\
50.6228 \\
45.5984 \\
51.7252 \\
61.5912 \\
50.2701\end{array}$ \\
\hline SWEDEN & $\begin{array}{l}1966 \\
1967 \\
1968 \\
1969 \\
1970 \\
1971 \\
1972 \\
1973 \\
1974 \\
1975\end{array}$ & $\begin{array}{l}0.3224 \\
0.3448 \\
0.3464 \\
0.3474 \\
0.3313 \\
0.3710 \\
0.3551 \\
0.3810 \\
0.3205 \\
0.2382\end{array}$ & $\begin{array}{l}-0.6473 \\
-0.6617 \\
-0.6590 \\
-0.6621 \\
-0.6324 \\
-0.6784 \\
-0.6697 \\
-0.7435 \\
-0.7528 \\
-0.6047\end{array}$ & $\begin{array}{l}0.9072 \\
0.8853 \\
0.8786 \\
0.9074 \\
0.8969 \\
0.8531 \\
0.8595 \\
0.8505 \\
0.9642 \\
0.8321\end{array}$ & $\begin{array}{l}-0.9072 \\
-0.8853 \\
-0.8786 \\
-0.9074 \\
-0.8969 \\
-0.8531 \\
-0.8595 \\
-0.8505 \\
-0.9642 \\
-0.8321\end{array}$ & $\begin{array}{l}19.6731 \\
19.1689 \\
18.7447 \\
17.8308 \\
16.3902 \\
16.9927 \\
17.2601 \\
19.6697 \\
20.0200 \\
18.9667\end{array}$ \\
\hline SWITZERL. & $\begin{array}{l}1966 \\
1967 \\
1968 \\
1969 \\
1970 \\
1971 \\
1972 \\
1973 \\
1974 \\
1975\end{array}$ & $\begin{array}{l}-0.1420 \\
-0.1327 \\
-0.1326 \\
-0.1298 \\
-0.1223 \\
-0.1203 \\
-0.1338 \\
-0.1612 \\
-0.1881 \\
-0.1949\end{array}$ & $\begin{array}{l}0.0000 \\
0.0000 \\
0.0000 \\
0.0000 \\
0.0000 \\
0.0000 \\
0.0000 \\
0.0000 \\
0.0000 \\
0.0000\end{array}$ & $\begin{array}{l}0.0000 \\
0.0000 \\
0.0000 \\
0.0000 \\
0.0000 \\
0.0000 \\
0.0000 \\
0.0000 \\
0.0000 \\
0.0000\end{array}$ & $\begin{array}{l}1.1971 \\
1.1588 \\
1.1670 \\
1.1798 \\
1.1778 \\
1.1374 \\
1.1587 \\
1.1993 \\
1.2711 \\
1.1995\end{array}$ & $\begin{array}{l}18.3110 \\
17.9136 \\
17.3806 \\
16.5833 \\
15.8209 \\
16.1329 \\
17.7797 \\
20.7072 \\
22.9918 \\
27.5425\end{array}$ \\
\hline
\end{tabular}


TABLE III.IO CONTD.

VARIOUS ELASTICITIES DF DEMAND: MODEL I

COUNTRY

U. K.

$\begin{array}{ll}1956 & -0.1539 \\ 1967 & -0.1457 \\ 1968 & -0.1381 \\ 1969 & -0.1316 \\ 1970 & -0.1210 \\ 1971 & -0.1116 \\ 1972 & -0.1031 \\ 1973 & -0.1092 \\ 1974 & -0.1556 \\ 1975 & -0.1278\end{array}$

CANADA

1966
1967
1968
1969
1970
1971
1972
1973
197
1975
YEAR

$E(D(t), P(t))$

CANADA $\quad \begin{aligned} & 1966 \\ & 1967 \\ & 1968 \\ & 1969 \\ & 1970 \\ & 1971 \\ & 1972 \\ & 1973 \\ & 197 \\ & 1975\end{aligned}$

0.0000
0.0000
0.0000
0.0000
0.0000
0.0000
0.0000
0.0000
0.0000
0.0000

0.0000
U.S.
$E(D(t), P(t-1))$
$E(D(t), G(t)) E(D(t), G(t-1)) \cdot P \cdot F$.

$\begin{array}{ll}0.0000 & 0.0000 \\ 0.0000 & 0.0000 \\ 0.0000 & 0.0000 \\ 0.0000 & 0.0000 \\ 0.0000 & 0.0000 \\ 0.0000 & 0.0000 \\ 0.0000 & 0.0000 \\ 0.0000 & 0.0000 \\ 0.0000 & 0.0000 \\ 0.0000 & 0.0000\end{array}$

0.0000
0.0000
0.0000
0.0000
0.0000
0.0000
0.0000
0.0000
0.0000
0.0000

36.2178 35.3366 33.2891 31.4558 29.4521 27.2187

25.4847 25.4847 35.5041 29.2720

0.0000

0.0000 0.0000 0.0000 0.0000 0.0000 0.0000 0.0000 0.0000 0.0000

-1.2056
-1.0910
-0.9687
-1.1756
-0.9364
-1.0452
-1.0343
-1.0194
-0.9840
-0.9303

1.2056 1.0910

0.9687

1.1756

0.9364

1.0452

1.0343

1.0194

0.9840

0.9303

11.5845

11.3968

11.6087

10.4025

10.8247

10.4083

9.1241

9.7761

10.1441
9.5991

0.0000

0.0000

0.0000

0.0000

0.0000

0.0000

0.0000

0.0000

0.0000

0.0000

0.0000

0.0000

0.0000

0.0000

0.0000

0.0000

0.0000

0.0000

0.0000

$-0.5411$

$-0.5206$

$-0.5249$

$-0.5031$

$-0.4625$

$-0.4741$

$-0.4847$

$-0.4896$

-0.4592
-0.4415

0.5411

0.5206

0.5249

0.5031

0.4625

0.4741

0.4847

0.4896

0.4415

9.0803

8.5741

8.1786

8.0167

7.9365

7.3405

6.9271
8.7170

8.8275 
TABLF, III.II

AVERAGE ELASTICITIES FOR DIFFERENT RANGES OF P.F.: MODEL I

P.F.-RANGE

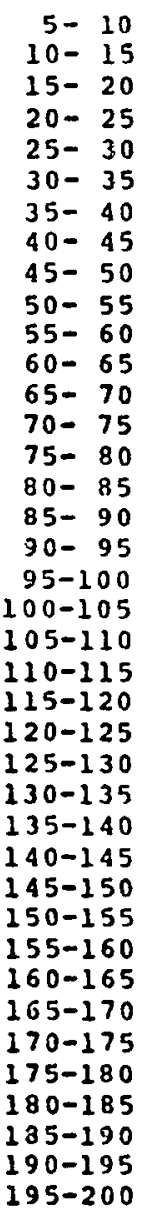

$E(D(t), P(t))$

$E(D(t), P(t-1)) E(D(t), G(t)$
$E(D(t), G(t-1))$

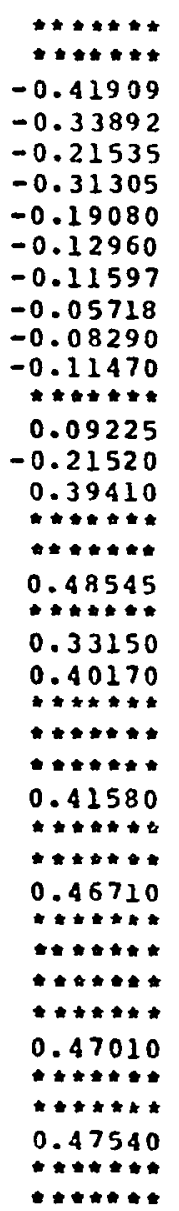

$-0.60656$

$-1.05807$

0.01870

$-0.09990$

0.63020

0.02697

$-0.19208$

$-0.92380$

$-0.60500$

$-1.09643$

$-1.10945$

$-0.56473$

t*1*\#

$-0.20745$

$-0.03670$

$-0.45260$

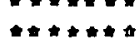

$-0.43425$

$-0.31060$

$-0.50810$

…"

40

$-0.49360$

$-0.49360$

*******

$-0.57240$

$\ldots \star \star \star \star *$

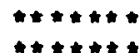

\#*****

$-0.55950$

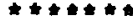

***t:

$-0.55980$

***t*
0.60556

1.05807

$-4.20248$

-4.20248
-0.75950

$-0.75950$

$-0.34656$

-0.04045
0.59380

0.62647

0.99795

1.18290

0.82660

******

0.75010

0.92880

0.70650

$* * * * * * *$

0.71140

tit.

0.56350

0.75190

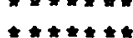

- +*

0.72900

***t*

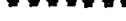

0.80590

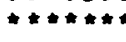

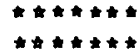

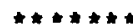

0.77730

.

***A*

0.77680

******* 
demand intensity with respect to current prices for different intervals of the ratio $P . F$. The table reveals a aistinct inverse relationship between the values of $P . F$. and $E(D(t), P(t))$; a result in good agreement with basic economic theory.

In order to find a functional relationship between $E(D(t), P(t))$ and $R$, the following seven functional forms were fitted to the values in table III.ll via O.L.S.:

$$
\begin{aligned}
& \text { 1. } E=A+B \cdot(P \cdot F \cdot) \\
& \text { 2. } E=A \cdot E \operatorname{Ex}(B \cdot(P \cdot F \cdot)) \\
& \text { 3. } E=A \cdot(P \cdot F \cdot) \\
& \text { 4. } E=A+(B / P \cdot F \cdot) \\
& \text { 5. } E=1 /(A+B \cdot(P \cdot F \cdot)) \\
& \text { 6. } E=P \cdot F \cdot /(A+B \cdot(P \cdot F \cdot)) \\
& \text { 7. } E=A+B \cdot L O G(P \cdot F)
\end{aligned}
$$

where $A$ and $B$ are constants.

The results of the curve fitting are displayed in table III.12.

Based on the results in table III.12, the relationship between $E(D(t), P(t))$ and $R$ is assumed to be as follows: 
TABLE II I. 12

CURVE FI'T RESULTS OF E $(D(t), P(t))$ VS P P.F.: MODEL I

\begin{tabular}{|c|c|c|c|}
\hline CURVE TYPE & INDEX OF DETERMINATION & A & B \\
\hline $1 \cdot E=A+B \cdot(P \cdot F \cdot)$ & .831 & -.106 & -3.26 \\
\hline 2. $E=A \cdot \operatorname{EXP} \cdot(B \cdot(P \cdot F \cdot))$ & $\operatorname{CAN}^{\circ} \mathrm{T}$ FIT & & \\
\hline $3 \cdot E=A \cdot(P \cdot F \cdot)^{B}$ & $\operatorname{CAN}^{\circ} \mathrm{T}$ FIT & & \\
\hline $4 \cdot E=A+(B / P \cdot F \cdot)$ & .937 & -.738 & 24.37 \\
\hline $5 \cdot E=1 /(A+B \cdot(P \cdot F \cdot))$ & .464 & -5.92 & .0030 \\
\hline $6 \cdot E=R /(A+B \cdot(P \cdot F \cdot))$ & .785 & -277.5 & .645 \\
\hline 7. $E=A+B \cdot \log (P \cdot E \cdot)$ & .924 & .991 & -.317 \\
\hline
\end{tabular}

STANDARD ERROR EST IMATES

CURVE TYPE

1.

2.

3.

4.

5.

6.

7.
REGRESSION

.007

0

0

.004

1.55

.981

.005
A

B

$\begin{array}{cc}.004 & .00004 \\ 0 & 0 \\ 0 & 0 \\ .002 & 1.69 \\ .895 & .0009 \\ 38.79 & .579 \\ .108 & .002\end{array}$




\section{Results of Model I.I}

Table III.13 displays the various annual elasticities

for the fifteen OECD countries.

Comparing the values with those in table III.I0, the following observations may be made:

The elasticity estimates for Austria, Belgium, the Netheriands, Norway, Portugal and Switzerland show a slight positive shift with respect to those of model I. While the estimates remained virtually unchanged for Germany and Italy: Denmark, Spain and the U.K. showed a negative shift, and Luxembourg, a rather large positive shift.

The most appreciable shift in the elasticity estinates was associated with the U.S. and Canada which gave negative elasticities quite sizable for the corresponding values of P.F.

From an economic theory premise, model $I$ is more acceptable than the current model.

In order to even out possible anomalous estinates, such as those of the U.S. and Canada, the elasticity values were again averaged over the countries for the various P.F. intervals, giving the results in table III.14.

It can be seen from table III.14 that the first two values of $E(D(t), P(t))$ are rather $h i g h$ compared to the rest. The third value of .099 is small and anomalous compared to the rest, and to the "rational" economic behavior. 
TABLE III.I3

VARIOUS ELASTICITIES OF DEMAND: MODEL I.I

COUNTRY

YEAR

$E(D(t), P(t))$

$E(D(t), G(t)) \quad P . F$.

AUSTRIA

$$
\begin{aligned}
& 1966 \\
& 1967 \\
& 1968 \\
& 1969 \\
& 1970 \\
& 1971 \\
& 1972 \\
& 1973 \\
& 1974 \\
& 1975
\end{aligned}
$$

0.1663

0.1517

0.1613

0.1641

0.1631

0.1639

0.1622

0.1867

0.0805

$-0.0269$

BELGIUM

1966
1967
1968
1969
1970
1971
1972
1973
1974
1975

$-0.0259$

$-0.0176$

$-0.0137$

$-0.0105$

$-0.0054$

0.0001

$-0.0073$

$-0.0365$

$-0.1360$

$-0.1183$

$$
\begin{aligned}
& -0.8501 \\
& -0.8166 \\
& -0.8531 \\
& -0.8896 \\
& -0.9336 \\
& -0.9097 \\
& -0.9107 \\
& -0.9242 \\
& -1.0932 \\
& -0.9949
\end{aligned}
$$

37.4713

35.3043

32.6784

30.4778

27.5389

26.2562

26.1395

33.8805

41.0596

46.5348

DENMARK

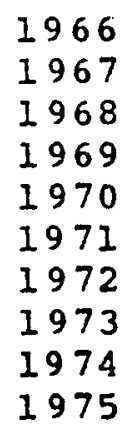

$-0.0603$

$-0.8999$

29.7962

$-0.0456$

$-0.9038$

27.7794

$-0.0324$

$-0.9661$

24.9544

$-0.0156$

$-1.0466$

22.6526

$-1.1021$

$-0.0001$

$-1.1311$

21.3133

20.9046

$-0.0026$

$-0.0027$

$-0.0974$

$-1.1908$

20.1246

24.6841

$-1.3473$

28.0058

$-0.1198$

$-1.2507$

25.7859 
TABLE III.I 3 CONTD.

VARIOUS ELASTICITIES OF DEMAND: MODEL I.I

COUNTRY

YEAR

$E(D(t), P(t))$

$E(D(t), G(t))$

P.F.

GERMANY

1966
1967
1968
1969
1970
1971
1972
1973
1974
1975

$-0.0076$

$-0.6175$

24.3985

$-0.0045$

$-0.5811$

$-0.6281$

$-0.6581$

$-0.0028$

$-0.0020$

$-0.6677$

$-0.6297$

$-0.0091$

$-0.6347$

$-0.0293$

$-0.0884$

$-0.0713$

$-0.6845$

$-0.7110$

$-0.6125$

24.5907

22.7256

21.1622

19.7428

20.8861

22.0462

30.8353

30.2865

28.8675

ITALY

1966

1967

1968

1969

1970

1971

1972

1973

1974

1975

$-0.3824$

$-0.3674$

0.0000

57.7092

0.0000

53.9667

$-0.3568$

0.0000

52.4713

$-0.3504$

0.0000

50.1333

$-0.3342$

0.0000

47.1221

$-0.3631$

0.0000

52.0690

$-0.3511$

0.0000

51.7416

$-0.3159$

0.0000

44.2021

$-0.4989$

0.0000

61.1969

$-0.3794$

0.0000

54.2663

LUXEMBOURG

$$
\begin{aligned}
& 1966 \\
& 1967 \\
& 1968 \\
& 1969 \\
& 1970 \\
& 1971 \\
& 1972 \\
& 1973 \\
& 1974 \\
& 1975
\end{aligned}
$$

0.0000

0.0000

0.0000

0.0000

0.0000

0.0000

0.0000

0.0000

0.0000

0.0000

-1.8491
-1.7506
-1.8245
-1.8515
-1.6094
-1.3745
-1.2646
-1.1259
-1.0911
-0.7419

22.9779

23.0221

22.1241

20.4934

19.3175

18.6520

17.0909

22.0920

24.8848

23.8558 
TABLE III.I3 CONTD.

VARIOUS ELASTICITIES OF DEMAND: MODEL I.I

COUNTRY

NETHERL .
YEAR

$$
\begin{aligned}
& 1966 \\
& 1967 \\
& 1968 \\
& 1969 \\
& 1970 \\
& 1971 \\
& 1972 \\
& 1973 \\
& 1974 \\
& 1975
\end{aligned}
$$

NORWAY

PORTUGAL

\begin{abstract}
1966
1967

1968

1969

1970

1971

1972

1973

1974

1975
\end{abstract}

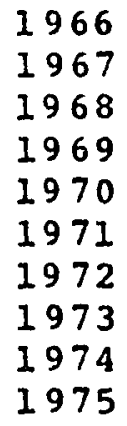

$E(D(t), P(t))$

$E(D(t), G(t)) \quad$ P.F.
$-0.9456$

$-0.9557$

$-0.9656$

$-1.0343$

$-1.0424$

$-1.0522$

$-1.0658$

$-1.1397$

$-1.3158$

$-1.1776$

2.4718

2.4303

2.3861

2.2867

2.2692

2.1656

2.1566

2.0948

2.4142

2.1666

$-0.3195$

$-0.5933$

$-0.5783$

$-0.5713$

$-0.5073$

$-0.4861$

$-0.4415$

$-0.4516$

$-0.4269$

$-0.6365$

$-0.3919$
32.9950

31.4689

29.7091

26.9871

25.5761

26.2032

28.7442

34.2620

36.8145

34.9556

29.5221

27.9846

26.8773

26.0571

23.5069

25.2107

24.1635

21.8789

32.8516

27.1676

188.7500

170.6964

149.0645

134.0308

112.1831

95.9474

83.7711

71.5217

95.5385

105.4756 
TABLE III.I 3 CONTD.

VARIOUS ELASTICITIES OF DEMAND: MODEL I.I

COUNTRY

YEAR

$E(D(t), P(t))$

$E(D(t), G(t))$

P.F.

SPAIN

1966

1967

1968

1969

1970

1971

1972

1973

1974

1975

$-0.4448$

$-0.3484$

$-0.2771$

$-0.2335$

$-0.1925$

$-0.1737$

$-0.1638$

$-0.1822$

$-0.2810$

$-0.2584$

0.2411

78.4725

0.2911

70.3617

0.3026

63.4694

0.3325

57.7308

0.3658

51.3761

0.3974

50.6228

0.4331

45.5984

0.4903

51.7252

0.5670

61.5912

0.5757

50.2701

SWEDEN

1966
1967
1968
1969
1970
1971
1972
1973
1974
1975

0.2076

$-0.8792$

19.6731

0.2258

$-0.8978$

19.1689

0.2275

$-0.9172$

18.7447

0.2281

$-0.9881$

0.2174

$-1.0663$

17.8308

0.2471

0.2339

0.2479

0.1927

0.1376

$-1.0738$

$-1.0818$

$-1.1088$

16.3902

16.9927

17.2601

19.6697

$-1.3244$

20.0200

$-1.2094$

18.9667

$\begin{array}{ll}\text { SWITZERL. } & 1966 \\ 1967 \\ 1968 \\ 1969 \\ 1970 \\ 1971 \\ 1972 \\ 1973 \\ 1974 \\ 1975\end{array}$

-0.0071
0.0007
0.0058
0.0059
0.0065
0.0106
-0.0058
-0.0520
-0.1266
-0.1712

$-1.5482$

$-1.4337$

$-1.4622$

$-1.4336$

$-1.3209$

$-1.2075$

$-1.1556$

$-1.1506$

$-1.1640$

$-0.9833$

18.3110
17.9136
17.3806
16.5833
15.8209
16.1329
17.7797
20.7072
22.9918
27.5425 
TABLE III.13 CONTD.

VARIOUS ELASTICITIES OF DEMAND: MODEL I.I

COUNTRY

YEAR

$E(D(t), P(t))$

$E(D(t), G(t)) \quad P . F$.

U.K.

1966

1967

1968

1969

1970

1971

1972

1973

1974

1975

$-0.1917$

$-0.1794$

$-0.1691$

$-0.1583$

$-0.1425$

$-0.1275$

$-0.1134$

$-0.1162$

$-0.1733$

$-0.1698$

0.7317

0.7103

0.7146

0.7203

0.7079

0.7062

0.6970

0.7331

0.7547

0.7520

36.2178

35.3366

33.2891

31.4558

29.4521

27.2187

25.4847

25.6653

35.5041

29.2720

CANADA

1966

1967

1968

1969

1970

1971

1972

1973

1974

1975

$-0.1221$

0.5589

11.5845

0.5058

11.3968

$-0.1081$

0.4491

11.6087

$-0.1115$

0.5450

10.4025

$-0.0972$

0.4341

10.8247

0.4846

0.4795

10.4083

$-0.0946$

0.4726

9.1241

$-0.0733$

0.4562

9.7761

$-0.1225$

0.4313

10.1441

9.5991

U.S.

$-0.7941$

9.2958

$-0.3803$

$-0.8049$

9.0803

$-0.3672$

$-0.8259$

8.5741

$-0.3449$

$-0.8225$

8.1786

$-0.3100$

$-0.7688$

8.0167

-0.3021
-0.2927

$-0.7750$

7.9365

$-0.2858$

$-0.8073$

7.3405

6.9271

$-0.3502$

-0.8539
-0.8385

8.7170

$-0.3781$

$-0.7881$

8.8275 
TABLE III.14

AVERAGE ELASTICITIES FOR DIFFERENT RANGES OF P.F.: MODEL I.I

P.F.-RANGE

$\begin{array}{r}5-10 \\ 10-15 \\ 15-20 \\ 20-25 \\ 25-30 \\ 30-35 \\ 35-40 \\ 40-45 \\ 45-50 \\ 50-55 \\ 55-60 \\ 60-65 \\ 65-10 \\ 70-75 \\ 75-80 \\ 80-85 \\ 85-90 \\ 90-195 \\ 95-100 \\ 100-105 \\ 105-110 \\ 110-115 \\ 115-120 \\ 120-125 \\ 125-130 \\ 130-135 \\ 135-140 \\ 140-145 \\ 145-150 \\ 150-155 \\ 155-160 \\ 160-165 \\ 165-170 \\ 170-175 \\ 175-180 \\ 180-185 \\ 185-190 \\ 190-195 \\ 195-200 \\ \hline\end{array}$

$E(D(t), P(t)) \quad E(D(t), G(t))$

$-0.28396$

$-0.11133$

0.09937

$-0.03197$

$-0.04931$

$-0.00034$

$-0.03140$

$-0.11770$

$-0.17497$

$-0.29750$

$-0.30795$

$-0.35233$

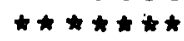

$-0.38765$

$-0.44480$

$-0.45160$

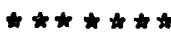

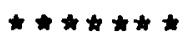

$-0.53900$

******

$-0.39190$

$-0.48610$

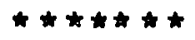

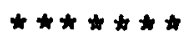

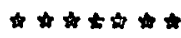

$-0.50730$

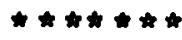

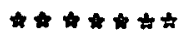

$-0.57130$

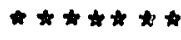

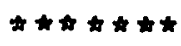

$\forall * \# * * *$

* *4* *4*

$-0.57830$

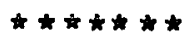

$\star \star \star \star * * \star * \star *$

$-0.59330$

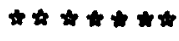

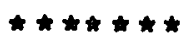

$-0.51505$

0.49053

$-1.18502$

$-0.71063$

0.04637

$-0.37303$

$-0.13097$

$-0.54660$

$-0.18727$

0.18292

0.16625

0.28987

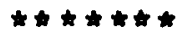

0.00170

0.24110

$-0.32780$

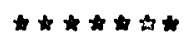

$\star * \star * * * *$

$-0.29355$

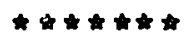

$-0.18060$

$-0.42120$

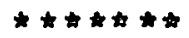

$\star \star * * * * *$

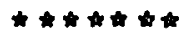

$-0.42320$

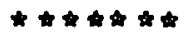

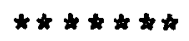

$-0.52350$

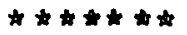

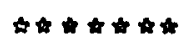

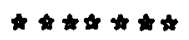

$-0.53290$

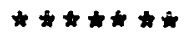

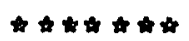

$-0.54390$

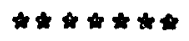

$\star \star \star \star \star \hbar \hbar \hbar$ $\hbar \hbar \star \star * t *$ 
TABLE III.I5

CURVE FIT RESUL'SS OF E(D(t),P(t)) VS. P.F.: MODEL I.I

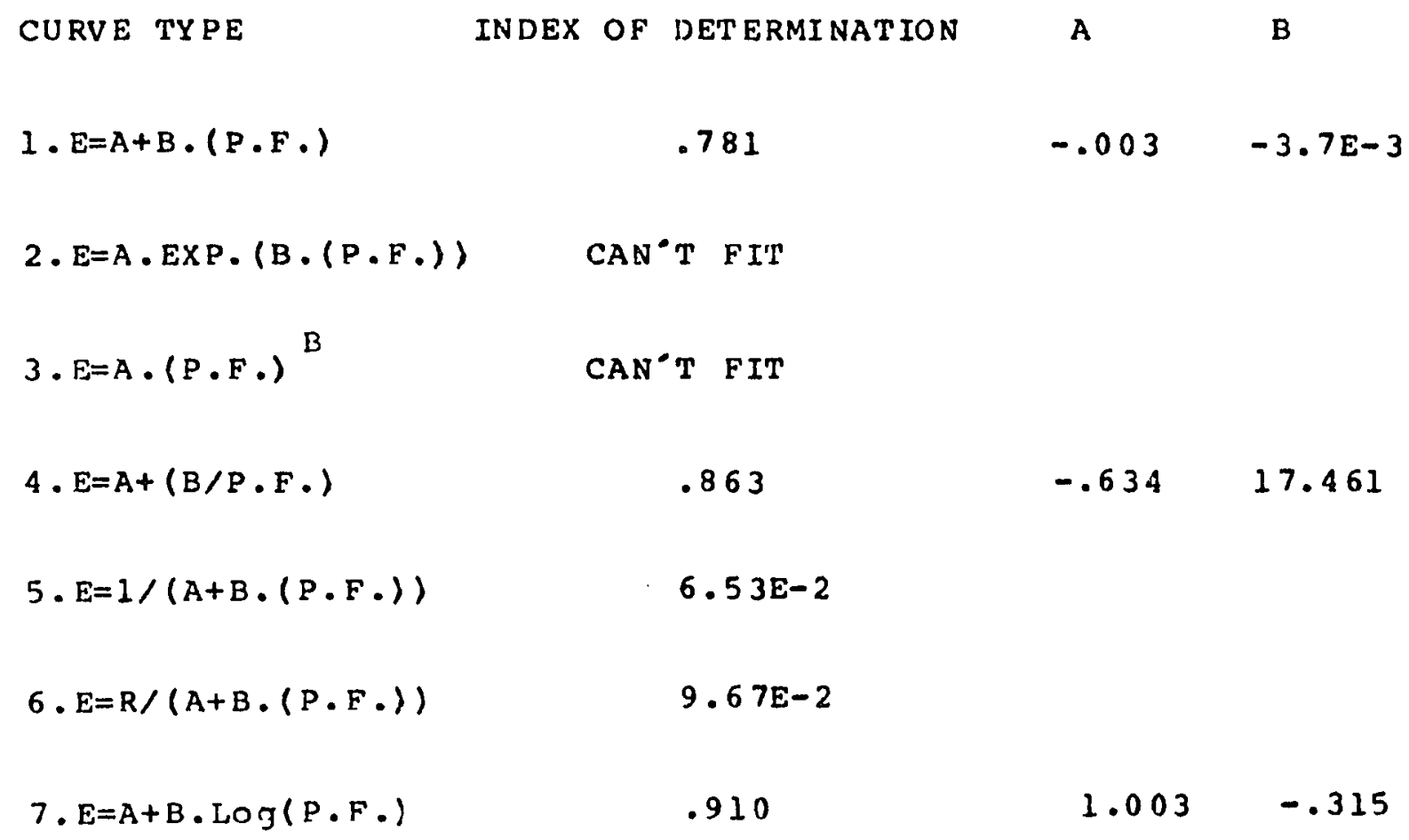

STANDARD ERROR ESTIMATES

CURVE TYPE

1 .

2 .

3.

4 .

5.

6.

7.
REGRESSION

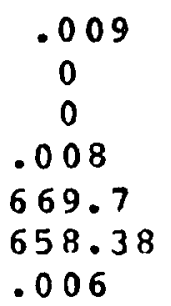

A

$\begin{array}{ll}.005 & .00005 \\ 0 & 0 \\ 0 & 0 \\ .003 & 1.69 \\ 306.6 & 3.206 \\ 14195.5 & 287.9 \\ .103 & .002\end{array}$


Neglecting the first three ranges, the elasticity behavior seems in good agreement with basic economic theory. After deleting the firat three ranges of P.F.. a curve fit performed on values in table III.I 4 yielded the results in table III.I.

The curve fitting of $E$ versus P.F. for model I.I yields the following functional form:

$E 2=1.003-.315 \log (P . F$.

Results of Model I.2

The annual elasticities of demand for the fifteen oEch countries resulting from model $I .2$ are displayed in table III.16.

A comparison with the results of models I and I.I reveals the following:

Compared to the other two models, there is a rather strong negative bias in the estimates for Austria, Belgium, Denmark, Germany, the Netherlands, Portugal, Sweden, Switzerland and the U.K. The estimates for spain were identical to those of model I.I while the U.S. and canada showed zero elasticities similar to model I. The estimates for Italy were slightly on the positive side compared to models I and I.I. Luxembourg aquired zero elasticities similar to those of model I.l while the values for Norway shifted negatively relative to those of $I .1$ getting closer to the estimates of model $I$. 
TABLE III.16

VARIOUS ELASTICITIES OF DEMAND: MODEL I.2

COUNTRY

AUSTRIA

BELGIUM

DENMARK
1966

1967

1968

1969

1970

1971

1972

1973

1974

1975

1966

1967

1968

1969

1970

1971

1972

1973

1974

1975

$E(D(t), P(t))$

$E(D(t), G(t)) \quad P . F$.

$$
\begin{aligned}
& -0.1178 \\
& -0.1066 \\
& -0.1031 \\
& -0.1002 \\
& -0.0951 \\
& -0.0883 \\
& -0.0880 \\
& -0.1158 \\
& -0.1660 \\
& -0.1712
\end{aligned}
$$

0.6326

0.6077

0.6348

0.6619

0.6947

0.6769

0.6777

0.6877

0.8135

0.7403

37.4713
35.3043
32.6784
30.4778
27.5389
26.2562
26.1395
33.8805
41.0596
46.5348

0.6435

32.5023

0.6198

0.6131

0.6440

0.6655

0.6825

0.6936

0.7676

0.8473

0.7364

31.2907

29.6498

27.2332

25.1306

25.0253

25.7732

32.0615

34.3375

28.4217

$-0.2344$

$-0.2354$

$-0.2516$

$-0.2726$

$-0.2870$

$-0.2946$

$-0.3101$

$-0.3195$

$-0.3509$

$-0.3257$
29.7962

27.7794

24.9544

22.6526

21.3133

20.9046

20.1246

24.6841

28.0058

25.7859 
TABLE III.I6 CONTD.

VARIOUS ELASTICITIES OF DEMAND: MODEL I.2

\begin{tabular}{|c|c|c|c|c|}
\hline COUNTRY & YEAR & $E(D(t), P(t))$ & $E(D(t), G(t))$ & P.F. \\
\hline \multirow[t]{2}{*}{ GE RMANY } & $\begin{array}{l}1966 \\
1967 \\
1968 \\
1969 \\
1970\end{array}$ & $\begin{array}{l}-0.1119 \\
-0.1062 \\
-0.1060 \\
-0.1035 \\
-0.0979\end{array}$ & $\begin{array}{l}-0.5429 \\
-0.4829 \\
-0.5319 \\
-0.4689 \\
-0.3928\end{array}$ & $\begin{array}{l}24.3985 \\
24.5907 \\
22.7256 \\
21.1622 \\
19.7428\end{array}$ \\
\hline & $\begin{array}{l}1971 \\
1972 \\
1973 \\
1974 \\
1975\end{array}$ & $\begin{array}{l}-0.0977 \\
-0.1039 \\
-0.1568 \\
-0.1600 \\
-0.1314\end{array}$ & $\begin{array}{l}-0.3156 \\
-0.3008 \\
-0.2923 \\
-0.2519 \\
-0.2114\end{array}$ & $\begin{array}{l}20.8861 \\
22.0462 \\
30.8353 \\
30.2865 \\
28.8675\end{array}$ \\
\hline ITALY & $\begin{array}{l}1966 \\
1967 \\
1968 \\
1969 \\
1970 \\
1971 \\
1972 \\
1973 \\
1974 \\
1975\end{array}$ & $\begin{array}{l}-0.2721 \\
-0.2589 \\
-0.2528 \\
-0.2439 \\
-0.2317 \\
-0.2569 \\
-0.2222 \\
-0.1967 \\
-0.3443 \\
-0.1842\end{array}$ & $\begin{array}{l}0.6548 \\
0.6728 \\
0.6720 \\
0.6908 \\
0.7009 \\
0.6891 \\
0.6706 \\
0.7063 \\
0.8056 \\
0.6910\end{array}$ & $\begin{array}{l}57.7092 \\
53.9667 \\
52.4713 \\
50.1333 \\
47.1221 \\
52.0690 \\
51.7416 \\
44.2021 \\
61.1969 \\
54.2663\end{array}$ \\
\hline LUXEMBOURG & $\begin{array}{l}1966 \\
1967 \\
1968 \\
1969 \\
1970 \\
1971 \\
1972 \\
1973 \\
1974 \\
1975\end{array}$ & $\begin{array}{l}0.00000 \\
0.00000 \\
0.00000 \\
0.00000 \\
0.00000 \\
0.00000 \\
0.00000 \\
0.00000 \\
0.00000 \\
0.000000\end{array}$ & $\begin{array}{l}-1.8491 \\
-1.7506 \\
-1.8245 \\
-1.8515 \\
-1.6094 \\
-1.3745 \\
-1.2646 \\
-1.1259 \\
-1.0911 \\
-0.7419\end{array}$ & $\begin{array}{l}22.9779 \\
23.0221 \\
22.1241 \\
20.4934 \\
19.3175 \\
18.6520 \\
17.0909 \\
22.0920 \\
24.8848 \\
23.8558\end{array}$ \\
\hline
\end{tabular}


TABLE III.I 6 CONTD.

VARIOUS ELASTICITIES OF DEMAND: MODEL I.2

$\begin{array}{lllll}\text { COUNTRY } & \text { YEAR } & E(D(t), P(t)) & E(D(t), G(t)) & P . F . \\ \text { NETHERL. } & & & \\ & 1966 & -0.0891 & 0.4353 & 32.9950 \\ 1967 & -0.0820 & 0.4400 & 31.4689 \\ 1968 & -0.0777 & 0.4445 & 29.7091 \\ 1969 & -0.0746 & 0.4762 & 26.9871 \\ 1970 & -0.0645 & 0.4799 & 25.5761 \\ 1971 & -0.0655 & 0.4844 & 26.2032 \\ 1972 & -0.0829 & 0.4907 & 28.7442 \\ 1973 & -0.1307 & 0.5247 & 34.2620 \\ 1974 & -0.2112 & 0.6058 & 36.8145 \\ 1975 & -0.1932 & 0.5421 & 34.9556 \\ & & & & \\ & & & & \\ \text { NORWAY } & 1966 & -0.3256 & 0.5878 & 29.5221 \\ & 1967 & -0.3149 & 0.5996 & 27.9846 \\ 1968 & -0.3100 & 0.6147 & 26.8773 \\ 1969 & -0.2980 & 0.6095 & 26.0571 \\ 1970 & -0.2777 & 0.6295 & 23.5069 \\ 1971 & -0.2924 & 0.6180 & 25.2107 \\ 1972 & -0.2897 & 0.6389 & 24.1635 \\ 1973 & -0.2659 & 0.6476 & 21.8789 \\ 1974 & -0.4748 & 0.7702 & 32.8516 \\ 1975 & -0.3688 & 0.7234 & 27.1676\end{array}$

PORTUGAL

$$
\begin{aligned}
& 1966 \\
& 1967 \\
& 1968 \\
& 1969 \\
& 1970 \\
& 1971 \\
& 1972 \\
& 1973 \\
& 1974 \\
& 1975
\end{aligned}
$$$$
\begin{aligned}
& -0.6674 \\
& -0.6505 \\
& -0.6427 \\
& -0.5706 \\
& -0.5468 \\
& -0.4966 \\
& -0.5080 \\
& -0.4802 \\
& -0.7160 \\
& -0.4409
\end{aligned}
$$

$-1.0660$

$-1.0426$

$-1.0200$

$-0.8191$

$-0.8121$

$-0.6665$

$-0.6217$

$-0.5384$

$-0.4366$

$-0.3316$
188.7500

170.6964

149.0645

134.0308

112.1831

95.9474

83.7711

71.5217

95.5385

105.4756 
TABLE III.16 CONTD.

VARIOUS ELASTICITIES OF DEMAND: MODEL I.2

\begin{tabular}{|c|c|c|c|c|}
\hline COUNTRY & YEAR & $E(D(t), P(t))$ & $E(D(t), G(t))$ & P. F. \\
\hline SPAIN & $\begin{array}{l}1966 \\
1967 \\
1968 \\
1969 \\
1970 \\
1971 \\
1972 \\
1973 \\
1974 \\
1975\end{array}$ & $\begin{array}{l}-0.4448 \\
-0.3484 \\
-0.2771 \\
-0.2335 \\
-0.1925 \\
-0.1737 \\
-0.1638 \\
-0.1822 \\
-0.2810 \\
-0.2584\end{array}$ & $\begin{array}{l}0.2411 \\
0.2911 \\
0.3026 \\
0.3325 \\
0.3658 \\
0.3974 \\
0.4331 \\
0.4903 \\
0.5670 \\
0.5757\end{array}$ & $\begin{array}{l}78.4725 \\
70.3617 \\
63.4694 \\
57.7308 \\
51.3761 \\
50.6228 \\
45.5984 \\
51.7252 \\
61.5912 \\
50.2701\end{array}$ \\
\hline SWEDEN & $\begin{array}{l}1966 \\
1967 \\
1968 \\
1969 \\
1970 \\
1971 \\
1972 \\
1973 \\
1974 \\
1975\end{array}$ & $\begin{array}{l}0.00000 \\
0.0000 \\
0.00000 \\
0.00000 \\
0.00000 \\
0.00000 \\
0.00000 \\
0.00000 \\
0.00000 \\
0.00000\end{array}$ & $\begin{array}{l}0.0000 \\
0.0000 \\
0.0000 \\
0.0000 \\
0.0000 \\
0.0000 \\
0.0000 \\
0.0000 \\
0.00000 \\
0.0000\end{array}$ & $\begin{array}{l}19.6731 \\
19.1689 \\
18.7447 \\
17.8308 \\
16.3902 \\
16.9927 \\
17.2601 \\
19.6697 \\
20.0200 \\
18.9667\end{array}$ \\
\hline SWITZERL。 & $\begin{array}{l}1966 \\
1967 \\
1968 \\
1969 \\
1970 \\
1971 \\
1972 \\
1973 \\
1974 \\
1975\end{array}$ & $\begin{array}{l}-0.3129 \\
-0.2924 \\
-0.2922 \\
-0.2861 \\
-0.2695 \\
-0.2651 \\
-0.2949 \\
-0.3553 \\
-0.4145 \\
-0.4295\end{array}$ & $\begin{array}{l}-1.4656 \\
-1.3439 \\
-1.3660 \\
-1.3186 \\
-1.1841 \\
-1.0593 \\
-0.9906 \\
-0.9690 \\
-0.9622 \\
-0.8030\end{array}$ & $\begin{array}{l}18.3110 \\
17.9136 \\
17.3806 \\
16.5833 \\
15.8209 \\
16.1329 \\
17.7797 \\
20.7072 \\
22.9918 \\
27.5425\end{array}$ \\
\hline
\end{tabular}


TABLE III.16 CONTD.

VARIOUS ELASTICITIES OF DEMAND: MODEL I.2

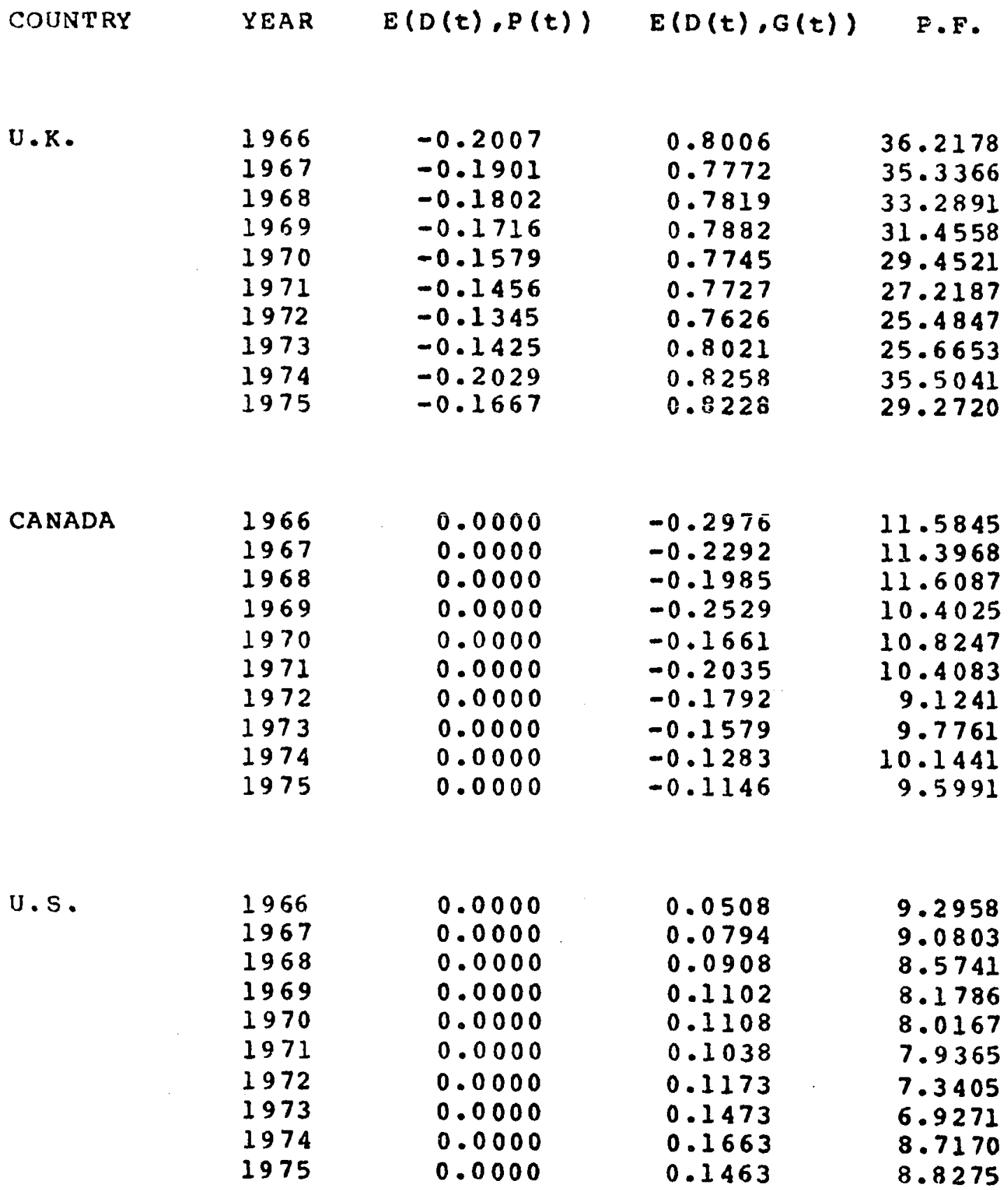


Table III.I7 displays the average elasticitles for different $r$ anges of $P . F$. The fitted curve to the results of model I.2 is given by equation 3.15 below

$E 3=P \cdot F \cdot /(-153 \cdot 26-.719$ P.F.)

Figure III.I depicts a plot of the three functional forms of of $E(D(t), P(t))$ versus $P . F$. It should be observed that these functions are defined for the specified ranges of P.F. only, i.e. P.F. values between 15 and 190 . It is assumed that the price elasticity of demand intensity for motor gasoline is zero for P.F. values below 15.

It is in this researcher's opinion that an P.F. value around 15 is a good indication of the range for which the widely accepted assumption of price-inelastic demand might hold.

THE P(t-1) ELASTICITY OF DEMAND

The elasticities of demand with respect to lagged prices, calculated from the different models were as follows:

Results of Model I

The annual elasticities of demand intensity for the fifteen OECD countries are displayed in table III.10. These values were calculated from the regression coefficients in table III.1 by applying formulae 2.15 and 2.16 . We can see from the table that while $E(D(t), P(t-1))$ 
FIGURE III.1

PLOTS OF THE THREE ESTTMATED ELASTICITY FUNCTIONS

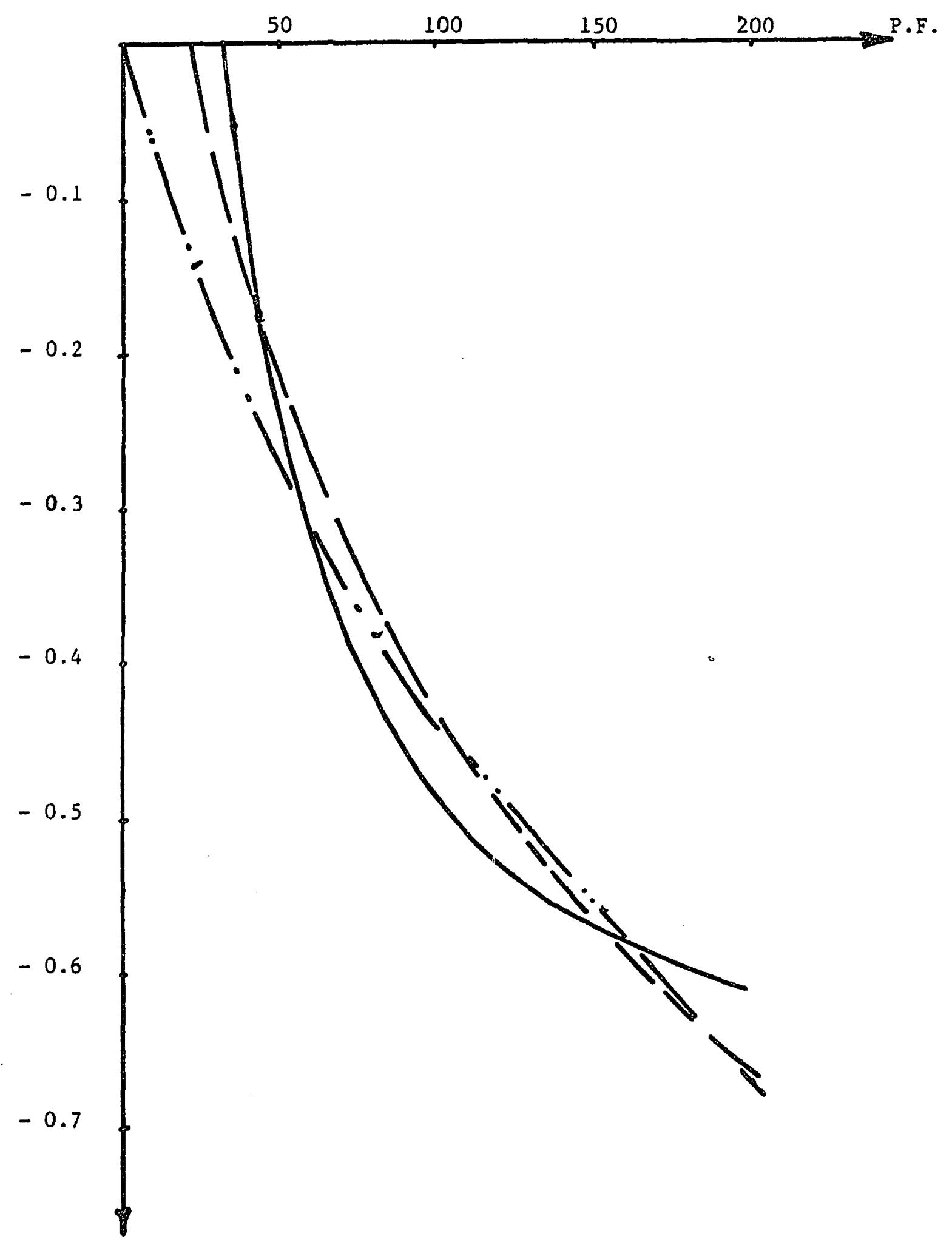


TABLE III. 17

AVERAGE ELASTICITIFS FOR DIFFERENT RANGES OF P.F.: MODEL I.2

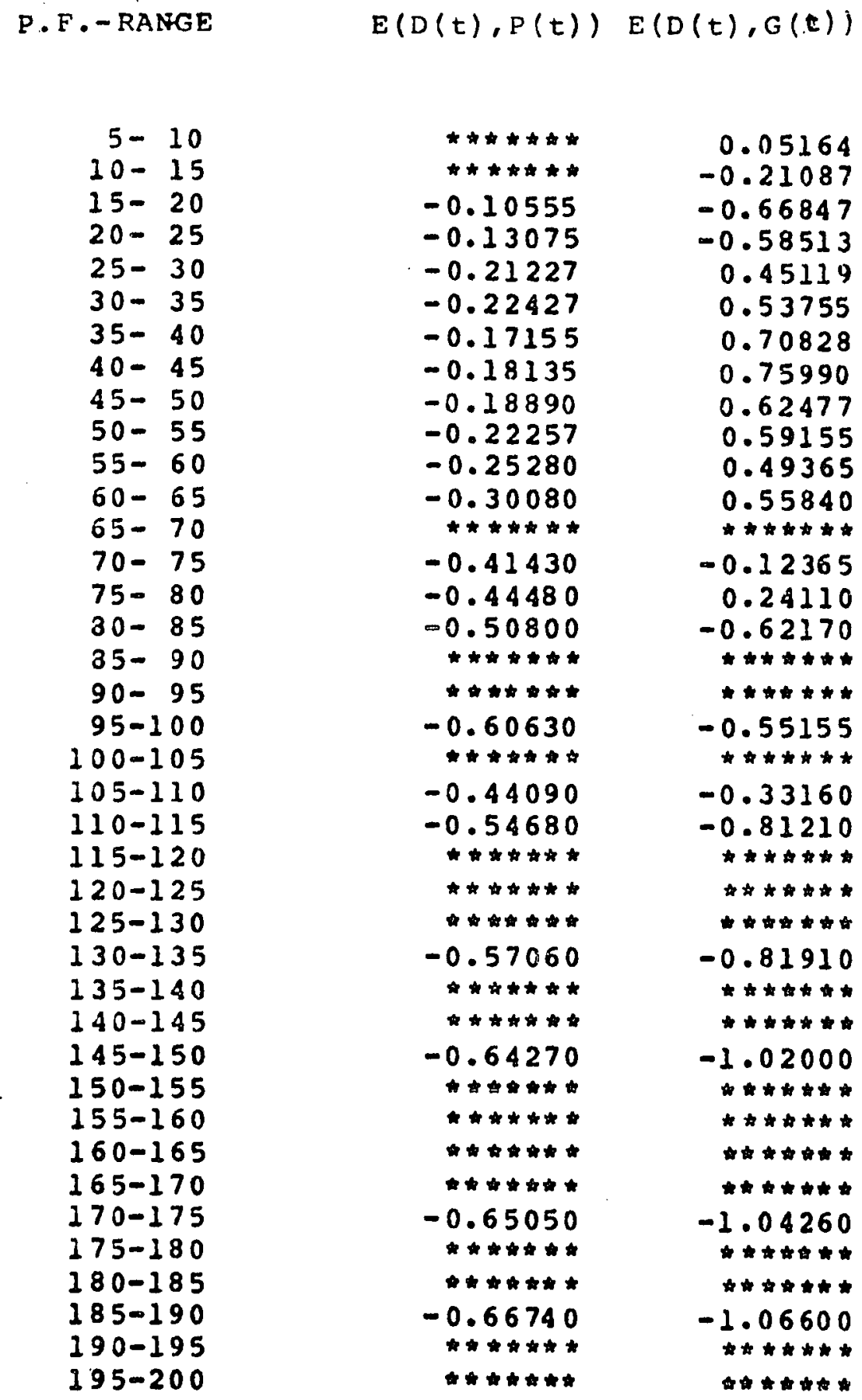


TABLE III. 18

CURVE FIT RESULTS OF E(D(t),P(t)) VS. P.F.: MODEL I.2

\begin{tabular}{|c|c|c|c|}
\hline CURVE TYPE & INDEX OF DESERMINATION & A & B \\
\hline $1 \cdot E=A+B \cdot(P \cdot F \cdot)$ & .874 & -.009 & -.0004 \\
\hline 2. $E=A \cdot E X P \cdot(P \cdot F \cdot)$ & $\mathrm{CAN}^{\circ} \mathrm{T}$ FIT & & \\
\hline $3 \cdot E=A \cdot(P \cdot F \cdot)^{B}$ & $\mathrm{CAN}^{\circ} \mathrm{T}$ FIT & & \\
\hline 4. $E=A+(B / P \cdot F \cdot)$ & .686 & -.598 & 11.63 \\
\hline 5. $E=1 /(A+B \cdot(P \cdot F \cdot))$ & .645 & -6.54 & .0036 \\
\hline $6 \cdot E=R /(A+B \cdot(P \cdot F \cdot))$ & .895 & -153.26 & -.719 \\
\hline 7. $E=A+B \cdot \log (P \cdot F \cdot)$ & .884 & .750 & -.269 \\
\hline
\end{tabular}

STANDARD ERROR ESTIMATES

CURVE TYPE

1.
2.
3.
4.
5.
7.
REGRESSION

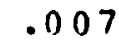

0

0

.112

1.38

.750

.006
A $B$

$\begin{array}{cc}.003 & .00003 \\ 0 & 0 \\ 0 & 0 \\ .004 & 1.85 \\ .588 & .0006 \\ 12.39 & .292 \\ .010 & .002\end{array}$


values were generally strongly negative for most countries, the elasticities calculated for Portugal were unreasonably large.

The averagea elasticity values for various ranges of $R$ displayed in table III.l1 clearly indicate an trregular and economically unreasonable behavior.

It should be pointed out that, in calculating $E(D(t), P(t-1))$ by formula 2.15 , the partial derivative of $D(t)$ with respect to $P(t)$ was assumed zero. It is for this reason and in order to avoid any possible interference of the current prices that model I.3 was formulated with lagged variables alone.

The following section gives the results of model I.3.

Results of Model I.3

Table III.19 contains the calculated values of the annual elasticities of demand with respect to $P(t-1)$ as calculated from model I.3. Table III.20 displays the elasticity values averaged over the various ranges of $P$.F. The results in both tables III.19 and III.20 indicate that elasticities as calculated from model I.3 share the same features as those calculated from model $I$.

Results of Model I.4

Tables III.2I and III.22 display the varlous annual elasticities for the different countries and the averaged values over P.F.intervals, respectively. The results are still not acceptable. The introduction of $N(t)$ to model I.4 
TABLE III.19

VARIOUS ELASTICITIES OF DEMAND: MODEL I.3

COUNTRY

YEAR

$E(D(t), P(t-1))$

$E(D(t), G(t-1)) \quad P . F$.

AUSTRIA

1966
1967
1968
1969
1970
1971
1972
1973
1974
1975

$-0.2383$

$-0.2226$

$-0.2115$

$-0.2060$

$-0.1980$

$-0.1777$

$-0.1684$

$-0.1714$

$-0.2657$

$-0.3114$

0.6343

0.6058

0.6110

0.6429

0.6623

0.6579

0.6542

0.6688

0.7998

0.7733

37.4713

35.3043

32.6784

30.4778

27.5389

26.2562

26.1395

33.8805

41.0596

46.5348

BELGIUM

1966
1967
1968
1969
1970
1971
1972
1973
1974
1975

0.0049

$-0.1370$

32.5023

0.0046

$-0.1174$

$-0.1068$

$-0.0948$

0.0043

$-0.0466$

0.0079

0.0189

0.0478

0.1177

0.1662

31.2907

29.6498

27.2 .332

25.1306

25.0253

25.7732

32.0615

34.3375

0.0033

28.4217

DENMARK

1966
1967
1968
1969
1970
1971
1972
1973
1974
1975

0.0018

0.0017

$-0.2371$

29.7962

27.7794

24.9544

0.0018

$-0.2457$

22.6526

0.0018

$-0.2581$

21.3133

0.0019

$-0.2862$

20.9046

0.0019

$-0.2931$

20.1246

0.0025

$-0.3194$

24.6841

0.0024

$-0.3601$

28.0058

0.0018

$-0.3362$

25.7859 
TABLE III. 19 CONTD.

VARIOUS ELASTICITIES OF DEMAND: MODEL I.3

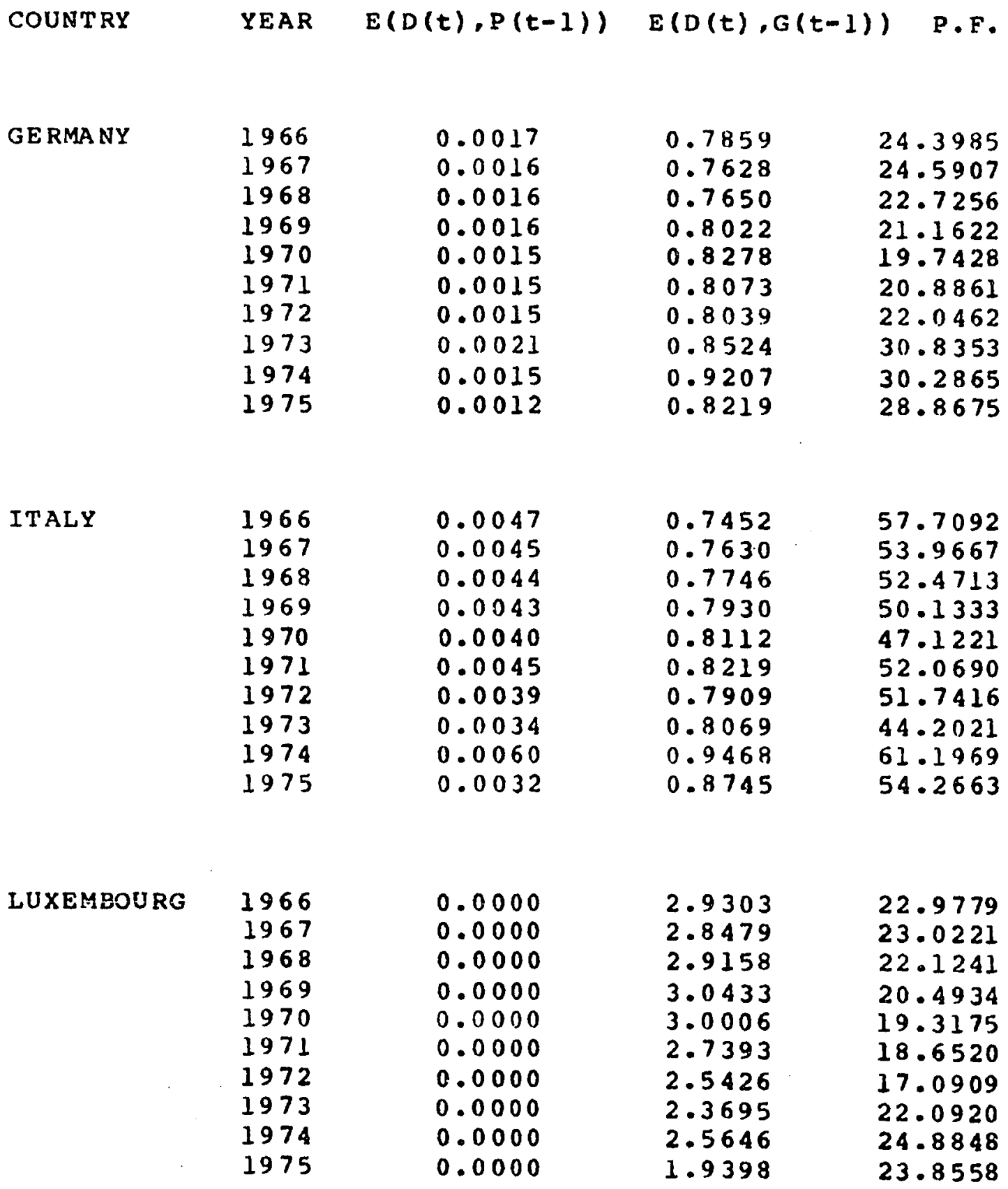


TABLE III.I9 CONTD.

VARIOUS ELASTICITIES OF DEMAND: MODEL I.3

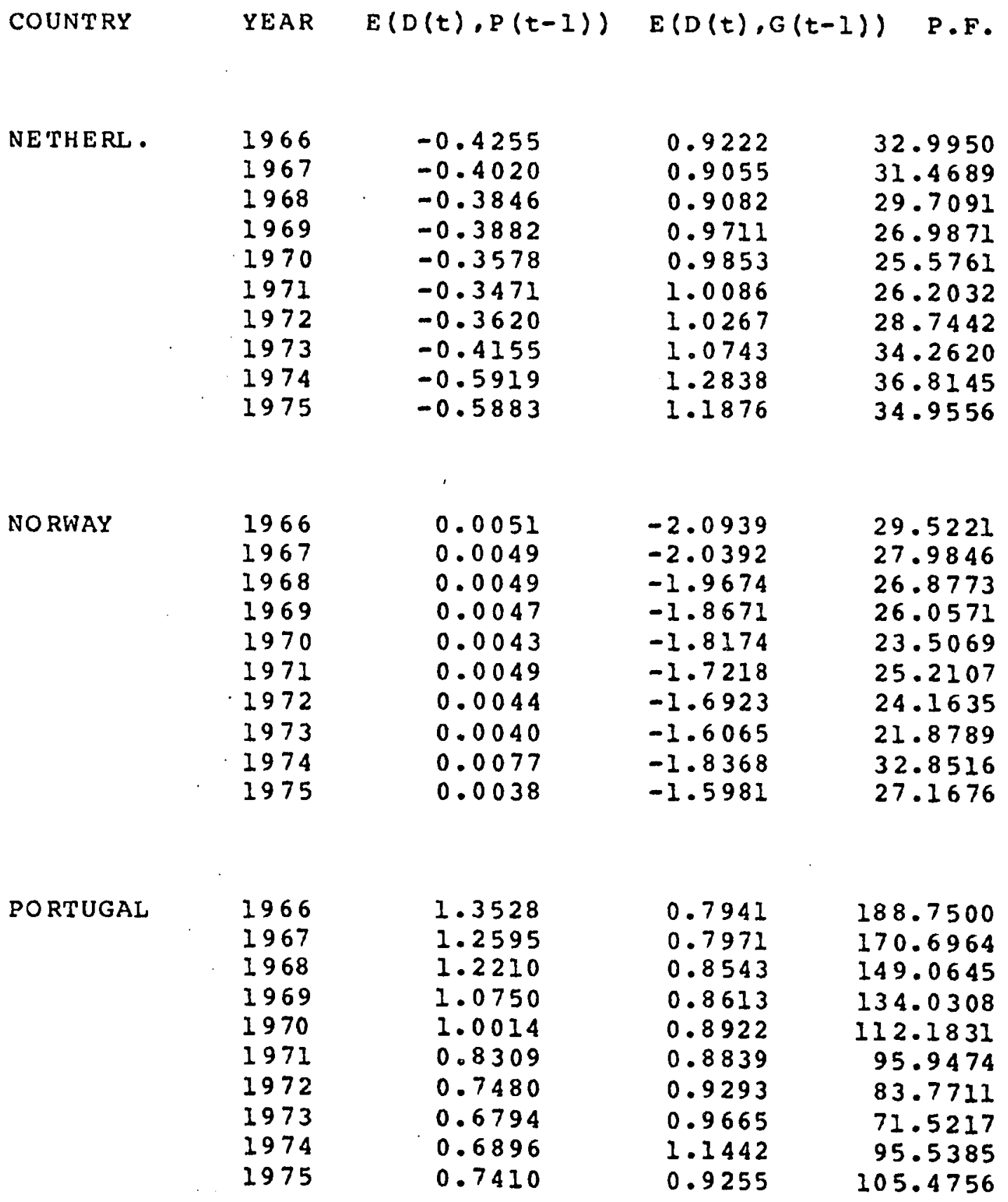


TABLE III.19 CONTD.

VARIOUS ELASTICITIES OF DEMAND: MODEL I.3

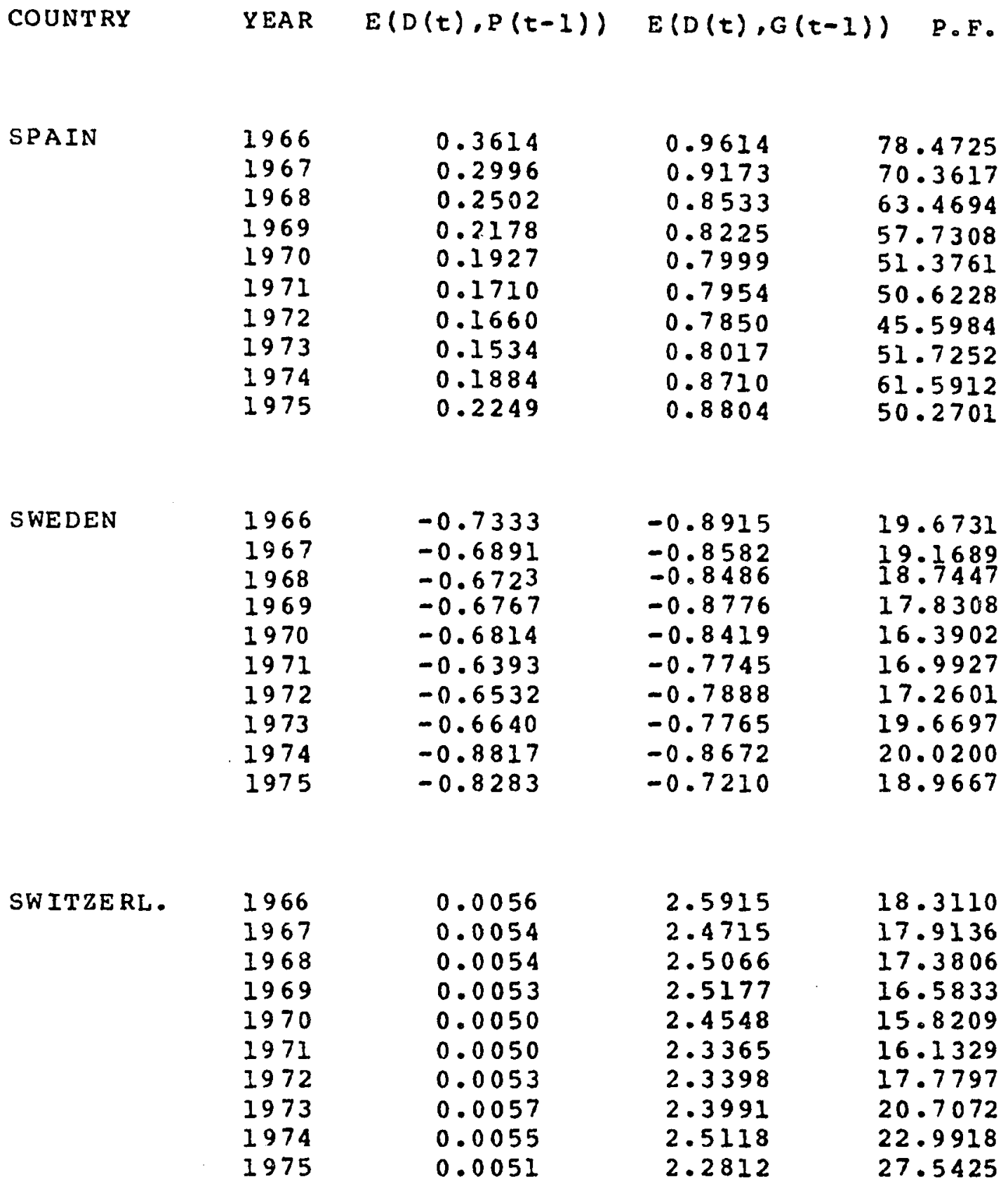


TABLE III.I 9 CONTD.

VARIOUS ELASTICITIES OF DEMAND: MODEL I. 3

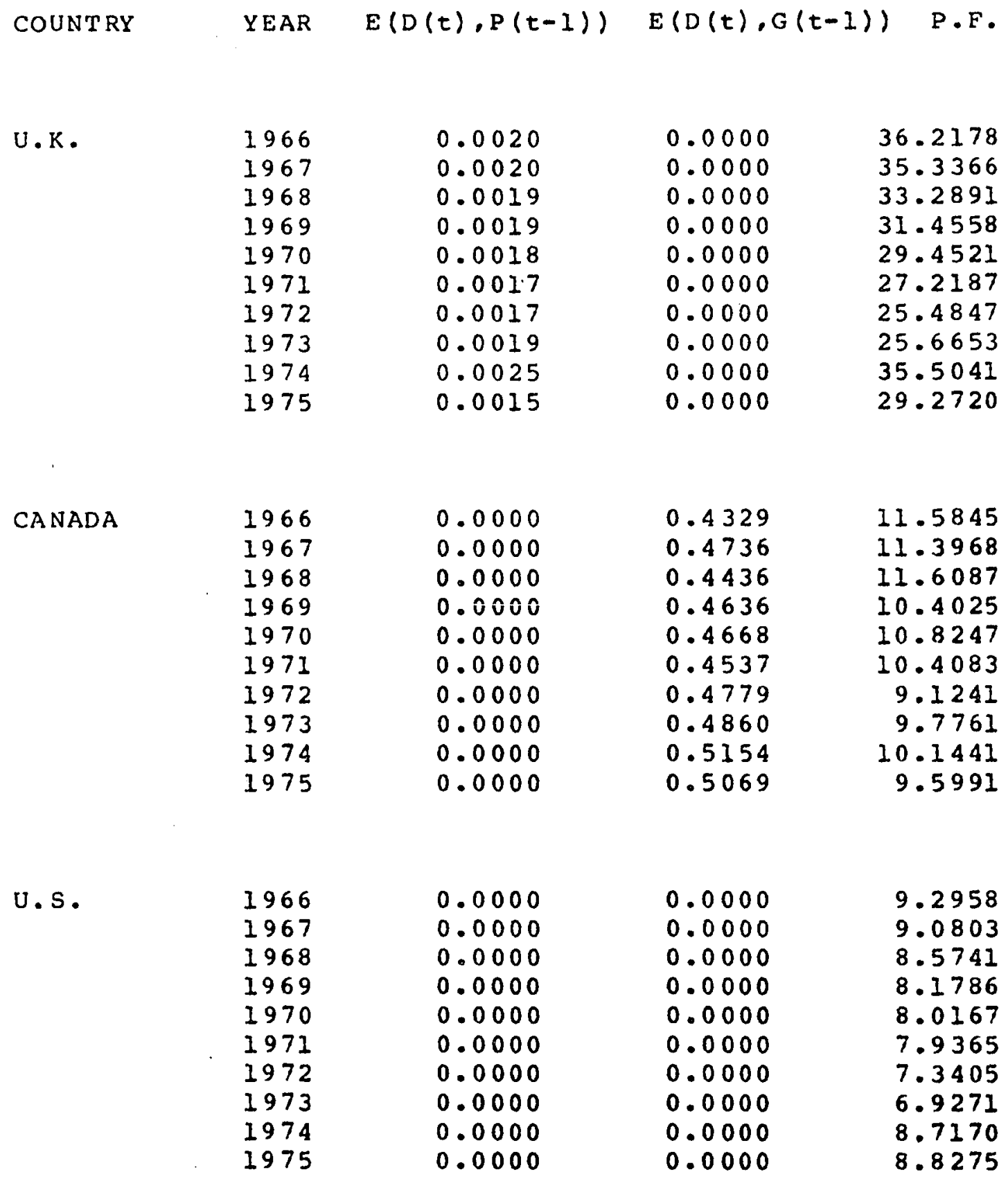


TABLE III. 20

AVERAGF ELASTICITIES FOR DIFFERENT RANGES OF P.F.: MODEL I.3

R-RANGE $\quad E(D(t), P(t-1)) \quad E(D(t), G(t-1))$

$$
\begin{aligned}
& 5-10 \\
& 10-15 \\
& 15-20 \\
& 20-25 \\
& 25-30 \\
& 30-35 \\
& 35-40 \\
& 40-45 \\
& 45-50 \\
& 50-55 \\
& 55-60 \\
& 60-65 \\
& 65-70 \\
& 70-75 \\
& 75-80 \\
& 80-85 \\
& 85-90 \\
& 90-95 \\
& 95-100 \\
& 100-105 \\
& 105-110 \\
& 110-115 \\
& 115-120 \\
& 120-125 \\
& 125-130 \\
& 130-135 \\
& 135-140 \\
& 140-145 \\
& 145-150 \\
& 150-155 \\
& 155-160 \\
& 160-165 \\
& 165-170 \\
& 170-175 \\
& 175-180 \\
& 180-185 \\
& 185-190 \\
& 190-195 \\
& 195-200 \\
& 19
\end{aligned}
$$

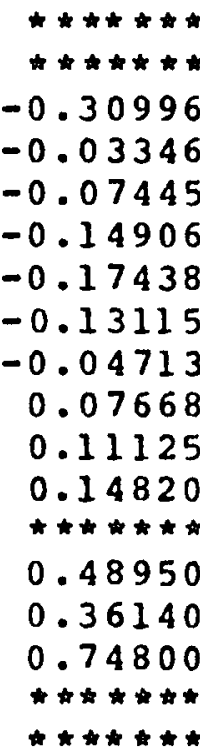

0.76025

$\star \star \star \star \star * \star * t$

0.74100

1.00140

$\star \star * \star * * *$

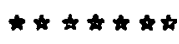

$\star * * * * * *$

1.07500

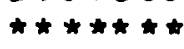

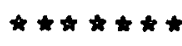

1.22100

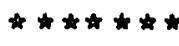

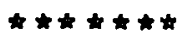

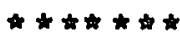

******

1.25950

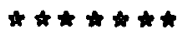

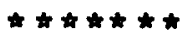

1. 35280

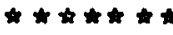

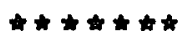

0.11314

0.46423

0.94750

0.82229

$-0.08172$

0.36623

0.42065

0.80335

0.78983

0.80953

0.78385

0.89037

*******

0.94190

0.96140

0.92930

$\hbar \star \star * t * \hbar$

*******

1.01405

******

0.92550

0.89220

$\star \star \star \star \star \star \star * *$

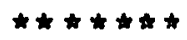

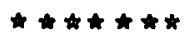

0.86130

$\star \star \star \star \star * \star * t$

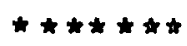

0.85430

$\star \star \star \star * \star * t$

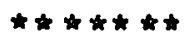

$\star * * * * * *$

*******

0.79710

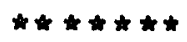

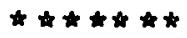

0.79410

***t*t

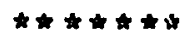


TABLE III.21

VARIOUS ELASTICITIES OF DEMAND: MODEL I.4

COUNTRY

AUSTRIA

BELGIUM

1966

1967

1968

1969

1970

1971

1972

1973

1974

1975

DENMA RK
1966
1967
1968
1969
1970
1971
1972
1973
1974
1975
$-0.2392$

$-0.2235$

$-0.2124$

$-0.2068$

$-0.1987$

$-0.1784$

$-0.1691$

$-0.1721$

$-0.2668$

$-0.3126$

$-0.0786$

$-0.0597$

$-0.0524$

$-0.0505$

$-0.0435$

$-0.0203$

$-0.0138$

0.0294

$-0.1610$

$-0.2776$
0.6343

0.6058

0.6110

0.6429

0.6623

0.6579

0.6542

0.6688

0.7998

0.7733

0.6707

0.6435

0.6263

0.6434

0.6700

0.7042

0.7041

0.7709

0.8725

0.8029
37.4713

35.3043

32.6784

30.4778

27.5389

26.2562

26.1395

33.8805

41.0596

46.5348

32.5023

31.2907

29.6498

27.2332

25.1306

25.0253

25.7732

32.0615

34.3375

28.4217
29.7962

27.7794

24.9544

22.6526

21.3133

20.9046

20.1246

24.6841

28.0058

25.7859 
TABLE III.2I CONTD.

VARIOUS ELASTICITIES OF DEMAND: MODEL I.4

COUNTRY

GE RMANY

ITALY

LUXEMBOURG
YEAR

1966

1967

1968

1969

1970

1971

1972

1973

1974

1975

1966

1967

1968

1969

1970

1971

1972

1973

1974

1975

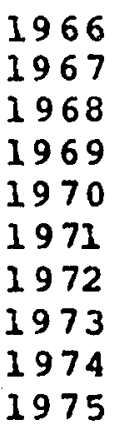

1966

1967

1969

1970

1971

1972

1973

1975

$$
\begin{aligned}
& -0.1362 \\
& -0.1265 \\
& -0.11279 \\
& -0.1240 \\
& -0.1191 \\
& -0.1084 \\
& -0.1142 \\
& -0.11278 \\
& -0.1930 \\
& -0.1693
\end{aligned}
$$

0.1007

0.0890

0.0944

0.0830

0.0715

0.1201

0.0547

0.0144

0.2254

$-0.0789$

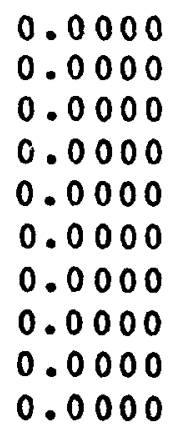

0.0000

.0000

.0000

0.0000

0.0000

0.0000

0.0000

0.0000
1.4985

1.4141

1.4807

I. 4984

1.4825

1. 3888

1.3805

1.4562

1. 5131

1. 3262

0.7180

0.7353

0.7464

0.7641

0.7817

0.7919

0.7621

0.7775

0.9123

0.8426
24.3985

24.5907

22.7256

21.1622

19.7428

20.8861

22.0462

30.8353

30.2865

28.8675

57.7092

53.9667

52.4713

50.1333

47.1221

52.0690

51.7416

44.2021

61.1969

54.2663
22.9779

23.0221

22.1241

20.4934

19.3175

18.6520

17.0909

22.0920

24.8848

23.8558 
TABLE III.2I CONTD.

VARIOUS ELASTICITIES OF DEMAND: MODEL I.4

\begin{tabular}{|c|c|c|c|c|}
\hline COUNTRY & YEAR & $E(D(t), P(t-1))$ & $E(D\langle t), G$ & P.F. \\
\hline NETHERL. & $\begin{array}{l}1966 \\
1967 \\
1968 \\
1969 \\
1970 \\
1971 \\
1972 \\
1973 \\
1974 \\
1975\end{array}$ & $\begin{array}{l}-0.3066 \\
-0.2897 \\
-0.2771 \\
-0.2798 \\
-0.2579 \\
-0.2501 \\
-0.2609 \\
-0.2994 \\
-0.4265 \\
-0.4239\end{array}$ & $\begin{array}{l}0.4396 \\
0.4316 \\
0.4329 \\
0.4629 \\
0.4697 \\
0.4808 \\
0.4894 \\
0.5121 \\
0.6120 \\
0.5661\end{array}$ & $\begin{array}{l}32.9950 \\
31.4689 \\
29.7091 \\
26.9871 \\
25.5761 \\
26.2032 \\
28.7442 \\
34.2620 \\
36.8145 \\
34.9556\end{array}$ \\
\hline NORWAY & $\begin{array}{l}1966 \\
1967 \\
1968 \\
1969 \\
1970 \\
1971 \\
1972 \\
1973 \\
1974 \\
1975\end{array}$ & $\begin{array}{r}-0.0084 \\
-0.0169 \\
-0.0127 \\
-0.0062 \\
-0.0305 \\
0.0371 \\
-0.0191 \\
-0.0349 \\
0.1580 \\
-0.1871\end{array}$ & $\begin{array}{l}0.5890 \\
0.5970 \\
0.6177 \\
0.6088 \\
0.6364 \\
0.6189 \\
0.6366 \\
0.6524 \\
0.7652 \\
0.7326\end{array}$ & $\begin{array}{l}29.5221 \\
27.9846 \\
26.8773 \\
26.0571 \\
23.5069 \\
25.2107 \\
24.1635 \\
21.8789 \\
32.8516 \\
27.1676\end{array}$ \\
\hline PORTUGAL & $\begin{array}{l}1966 \\
1967 \\
1968 \\
1969 \\
1970 \\
1971 \\
1972 \\
1973 \\
1974 \\
1975\end{array}$ & $\begin{array}{l}0.6714 \\
0.6543 \\
0.6465 \\
0.5740 \\
0.5500 \\
0.4995 \\
0.5110 \\
0.4830 \\
0.7202 \\
0.4435\end{array}$ & $\begin{array}{l}1.2463 \\
1.2480 \\
1.3052 \\
1.2164 \\
1.2562 \\
1.1829 \\
1.2172 \\
1.2263 \\
1.3315 \\
1.0453\end{array}$ & $\begin{array}{r}188.7500 \\
170.6964 \\
149.0645 \\
134.0308 \\
112.1831 \\
95.9474 \\
83.7711 \\
71.5217 \\
95.5385 \\
105.4756\end{array}$ \\
\hline
\end{tabular}


TABLE III.2I CONTD.

VARIOUS ELASTICITIES OF DEMAND: MODEL I.4

COUNTRY

SPAIN

SWEDEN

SWITZERL.
YEAR

1966

1967

1968

1969

1970

1971

1972

1973

1974

1975

1966

1967

1968

1969

1970

1971

1972

1973

1974

1975

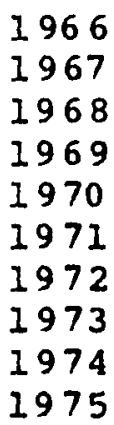

-1.1405
-0.9647
-0.8286
-0.7421
-0.6566
-0.6184
-0.5798
-0.5938
-0.6813
-0.6695

0.0000

0.0000

0.0000

0.0000

0.0000

0.0000

0.0000

0.0000

0.0000

c. 0000

$-0.4081$

$-0.3786$

$-0.3730$

$-0.3659$

$-0.3485$

$-0.3211$

$-0.3336$

$-0.3805$

$-0.4697$

$-0.492 I$
0.7614

0.7835

0.7399

0.7240

0.7341

0.7491

0.7474

0.7868

0.8904

0.9301

0.0000

0.0000

0.0000

0.0000

0.0000

0.0000

0.0000

0.0000

0.0000

0.0000

2.7025

2.5684

2.6092

2. 6168

2.5374

2.4067

2.4000

2. 4551

2.5625

2. 3040
78.4725

70.3617

63.4694

57.7308

51.3761

50.6228

45.5984

51.7252

61.5912

50.2701

19.6731

19.1689

18.7447

17.8308

16.3902

16.9927

17.2601

19.6697

20.0200

18.9667

18.3110

17.9136

17.3806

16.5833

15.8209

16.1329

17.7797

20.7072

22.9918

27.5425 
TABLE III.2I CONTD.

VARIOUS ELASTICITIES OF DEMAND: MODEL I.4

COUNTRY

$\mathrm{U} \cdot \mathrm{K} \cdot$

CANADA

U.S.
YEAR

$E(D(t), P(t-I))$

$E(D(t), G(t-1))$

0.7442

0.7227

0.7169

0.7299

0.7175

0.7129

0.7039

0.7162

0.7792

0.7861

1974

1975

$-0.0358$

$-0.2387$
0.0000
0.0000
0.0000
0.0000
0.0000
0.0000
0.0000
0.0000
0.0000
0.0000

1975

1972

1973

1974

$\begin{array}{ll}1966 & 0.0000 \\ 1967 & 0.0000 \\ 1968 & 0.0000 \\ 1969 & 0.0000 \\ 1970 & 0.0000 \\ 1971 & 0.0000 \\ 1972 & 0.0000 \\ 1973 & 0.0000 \\ 1974 & 0.0000 \\ 1975 & 0.0000\end{array}$

0.4329

0.4736

0.4436

0.4636

0.4668

0.4537

0.4779

0.4860

0.5154

0.5069

0.5414

0.5681

0.5709

0.5811

0.5614

0.5464

0.5538

0.5858

0.6161

0.5805
36.2178

35.3366

33.2891

31.4558

29.4521

27.2187

25.4847

25.6653

35.5041

29.2720
11.5845
11.3968
11.6087
10.4025
10.8247
10.4083
9.1241
9.7761
10.1441
9.5991
9.2958

9.0803

8.5741

8.1786

8.0167

7.9365

7.3405

6.9271

8.7170

8.8275 
TABLE III. 22

AVERAGE ELASTICITIES FOR DIFFERENT RANGES OF P.F.: MODEL I. 4

R-RANGE

$E(D(t), P(t)) \quad E(D(t), G(t))$
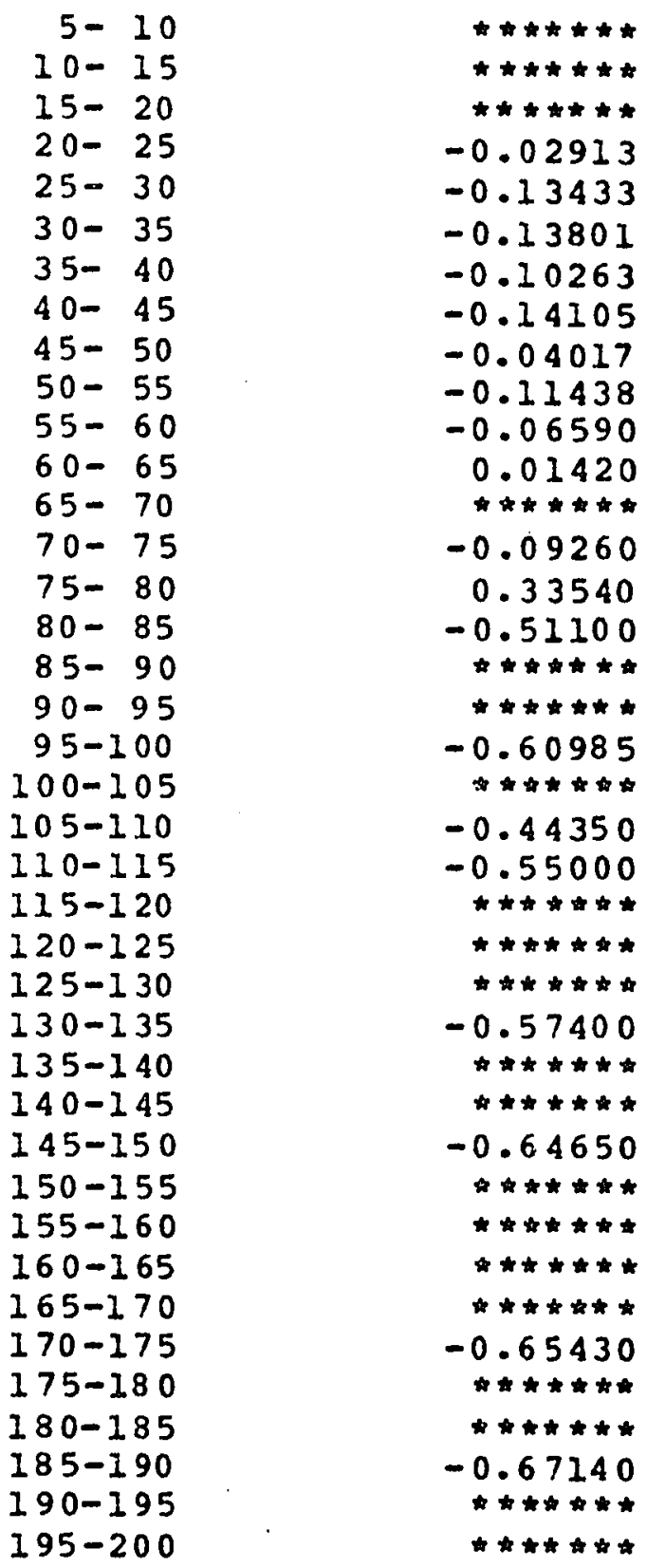

$\downarrow * \star * t *$

$t+t * t * t$

$-0.70652$

$-0.63579$

$-0.05347$

$-0.08527$

$\star \star \star \star \star * \star *$

t*t*t*t

0.12283

0.14591

0.22275

0.27370

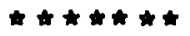

$-0.00010$

0.60570

$-0.53910$

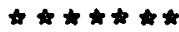

****t**

$-0.51725$

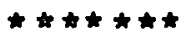

$-0.36990$

$-0.60520$

*******

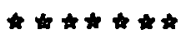

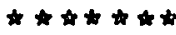

$-0.58790$

*******

$t+t+t$

$-0.68180$

$\omega * t * t *$

$\omega * * *+*$

$\omega * t+t$

$* * * *+*$

$-0.66640$

$\star * \star \star \star * \star *$

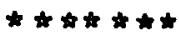

$-0.66680$

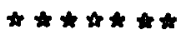

$\star \star \star t \star \hbar t$ 
resulted in model I.S whose results are discussed in the next section.

Results of Model I.5

The annual elasticities of demand and their average values over intervals of P.F. are shown in tables III.23 and III.24 respectively. The same shortcomings of previous models seem to be shared by the current one and the elasticity values estimated are still considered un reasonable.

It is concluded that according to the employed models, the current prices appear to be better parameters for determining demand elasticities than lagged prices.

\section{THE $G(t)$ ELASTICITY OF DEMAND}

Studying the possible influence of the per capita GNP on demand intensity in various countries ylelded the following results:

\section{Results of Model I}

Table III.10 contains the annual elasticities of demand for the fifteen OECD countries with respect to current GNP per capita, $E(D(t), G(t))$. It can be seen from the table that the elasticity coefficients vary intensively and irregularly over a wide range. The negative values calculated for seven of the fifteen countries indicate unreasonable economic behavior and are contradictory to 
TABLE III.23

\section{VARIOUS ELASTICITIES OF DEMAND: MODEL I.5}

COUNTRY

AUSTRIA

BELGIUM

DENMARK
YEAR

$E(D(t), P(t-1))$

$E(D(t), G(t-1)) P \cdot F$.

$$
\begin{aligned}
& 1966 \\
& 1967 \\
& 1968 \\
& 1969 \\
& 1970 \\
& 1971 \\
& 1972 \\
& 1973 \\
& 1974 \\
& 1975
\end{aligned}
$$

1966
1967
1968
1969
1970
1971
1972
1973
1974
1975

1966

1967

1968

1969

1970

1971

1972

1973

1974

1975

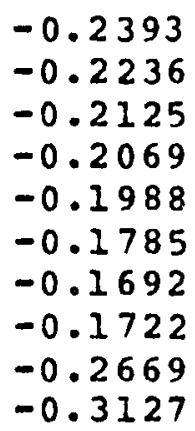

$-0.3127$

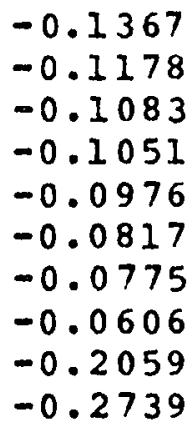

$-0.2739$

$-0.3160$

$-0.2965$

$-0.2894$

$-0.2731$

$-0.2750$

$-0.2649$

$-0.2713$

$-0.2725$

$-0.3769$

$-0.3993$

$$
\begin{aligned}
& 0.00000 \\
& 0.0000 \\
& 0.0000 \\
& 0.0000 \\
& 0.00000 \\
& 0.00000 \\
& 0.00000 \\
& 0.00000 \\
& 0.00000 \\
& 0.0000
\end{aligned}
$$

0.0000

0.0000

0.0000

0.0000

0.0000

0.0000

0.0000

0.0000

0.0000

0.0000

$-0.0822$

$-0.0783$

$-0.0873$

$-0.1078$

$-0.2557$

$-0.2850$

$-0.3178$

$-0.3820$

$-0.4856$

$-0.4564$
37.4713

35.3043

32.6784

30.4778

27.5389

26.2562

26.1395

33.8805

41.0596

46.5348

32.5023

31.2907

29.6498

27.2332

25.1306

25.0253

25.7732

32.0615

34.3375

28.4217

29.7962

27.7794

24.9544

22.6526

21.3133

20.9046

20.1246

24.6841

28.0058

25.7859 
TABLE III.23 CONTD.

VARIOUS ELASTICITIES OF DEMAND: MODEL I. 5

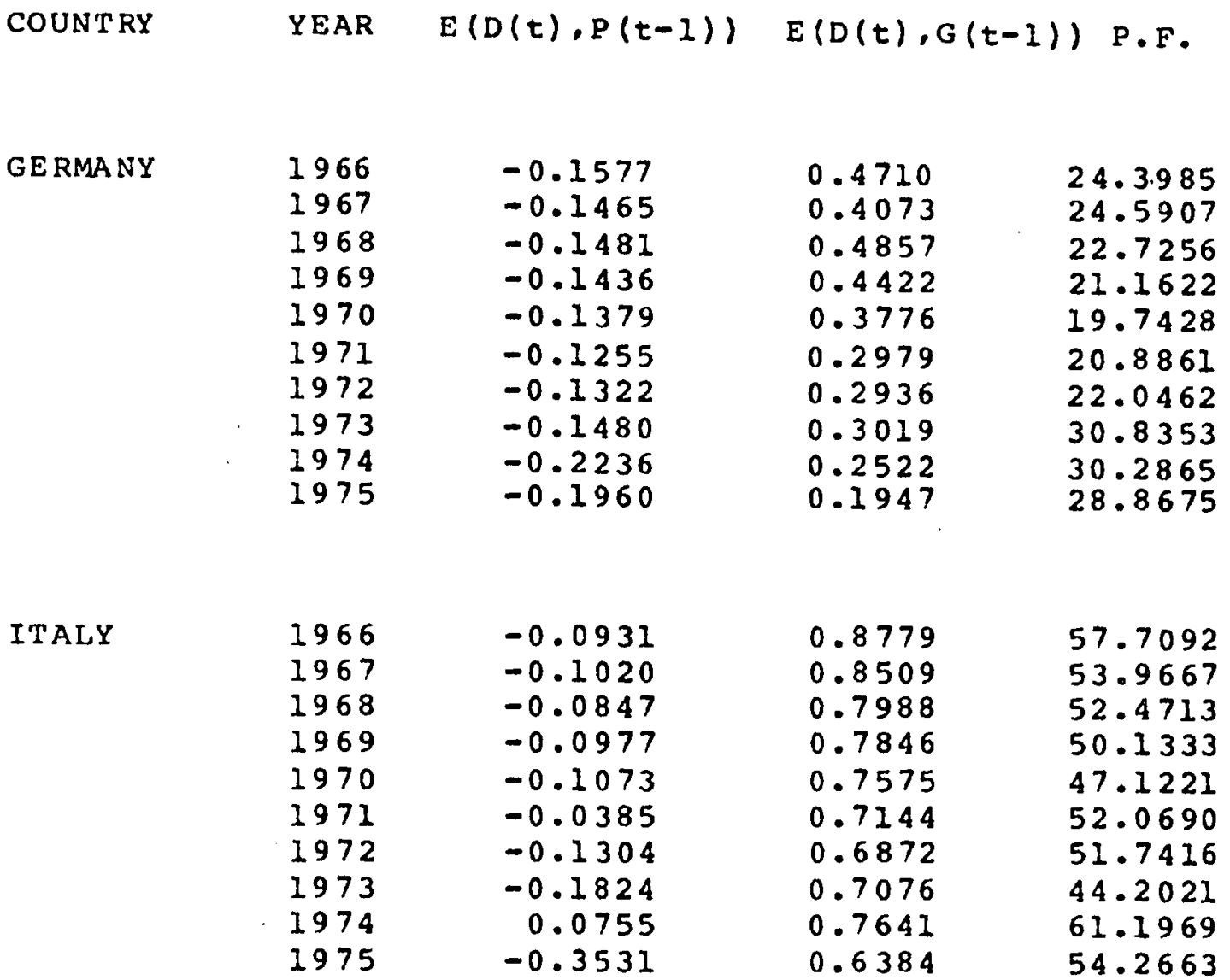

$\begin{array}{lllll}\text { LUXEMBOURG } & 1966 & 0.0000 & 2.9304 & 22.9779 \\ 1967 & 0.0000 & 2.8480 & 23.0221 \\ 1968 & 0.0000 & 2.9159 & 22.1241 \\ 1969 & 0.0000 & 3.0434 & 20.4934 \\ 1970 & 0.0000 & 3.0007 & 19.3175 \\ 1971 & 0.0000 & 2.7394 & 18.6520 \\ 1972 & 0.0000 & 2.5426 & 17.0909 \\ 1973 & 0.0000 & 2.3696 & 22.0920 \\ 1974 & 0.0000 & 2.5647 & 24.8848 \\ 1975 & 0.0000 & 1.9399 & 23.8558\end{array}$


TABLE III.23 CONTD.

VARIOUS ELASTICITIES OF DEMAND: MODEL I. 5

COUNTRY

NETHERL •

NORWAY

PORTUGAL
YEAR

1966

1967

1968

1969

1970

1971

1972

1973

1974

1975

1966

1967

1968

1969

1970

1971

1972

1973

1974

1975

1966
1967
1968
1969
1970
1971
1972
1973
1974
1975
$-0.6212$

$-0.5931$

$-0.5674$

$-0.5686$

$-0.5343$

$-0.5280$

$-0.5517$

$-0.6307$

$-0.8256$

$-0.7850$

0.0657

0.0567

0.0593

0.0616

0.0394

0.0954

0.0481

0.0318

0.2197

$-0.0789$

0.6041

0.5888

0.5817

0.5165

0.4949

0.4495

0.4598

0.4346

0.6481

0.3991
0.0650

0.0819

0.0344

$-0.0291$

$-0.1061$

$-0.1828$

$-0.2307$

$-0.2485$

$-0.4140$

$-0.4407$

$-2.8609$

$-2.8129$

$-2.7617$

$-2.6467$

$-2.6264$

$-2.5066$

$-2.496 I$

$-2.4246$

$-2.7943$

$-2.5076$

0.7043

0.7053

0.7366

0.6835

0.7057

0.6625

0.6808

0.6845

0.7388

0.5787
32.9950
31.4689
29.7091
26.9871
25.5761
26.2032
28.7442
34.2620
36.8145
34.9556

29.5221

27.9846

26.8773

26.0571

23.5069

25.2107

24.1635

21.8789

32.8516

27.1676
188.7500

170.6964

149.0645

134.0308

112.1831

95.9474

83.7711

.71 .5217

95.5385

105.4756 
TABLE III.23 CONTD.

VARIOUS ELASTICITIES OF DEMAND: MODEL I.5

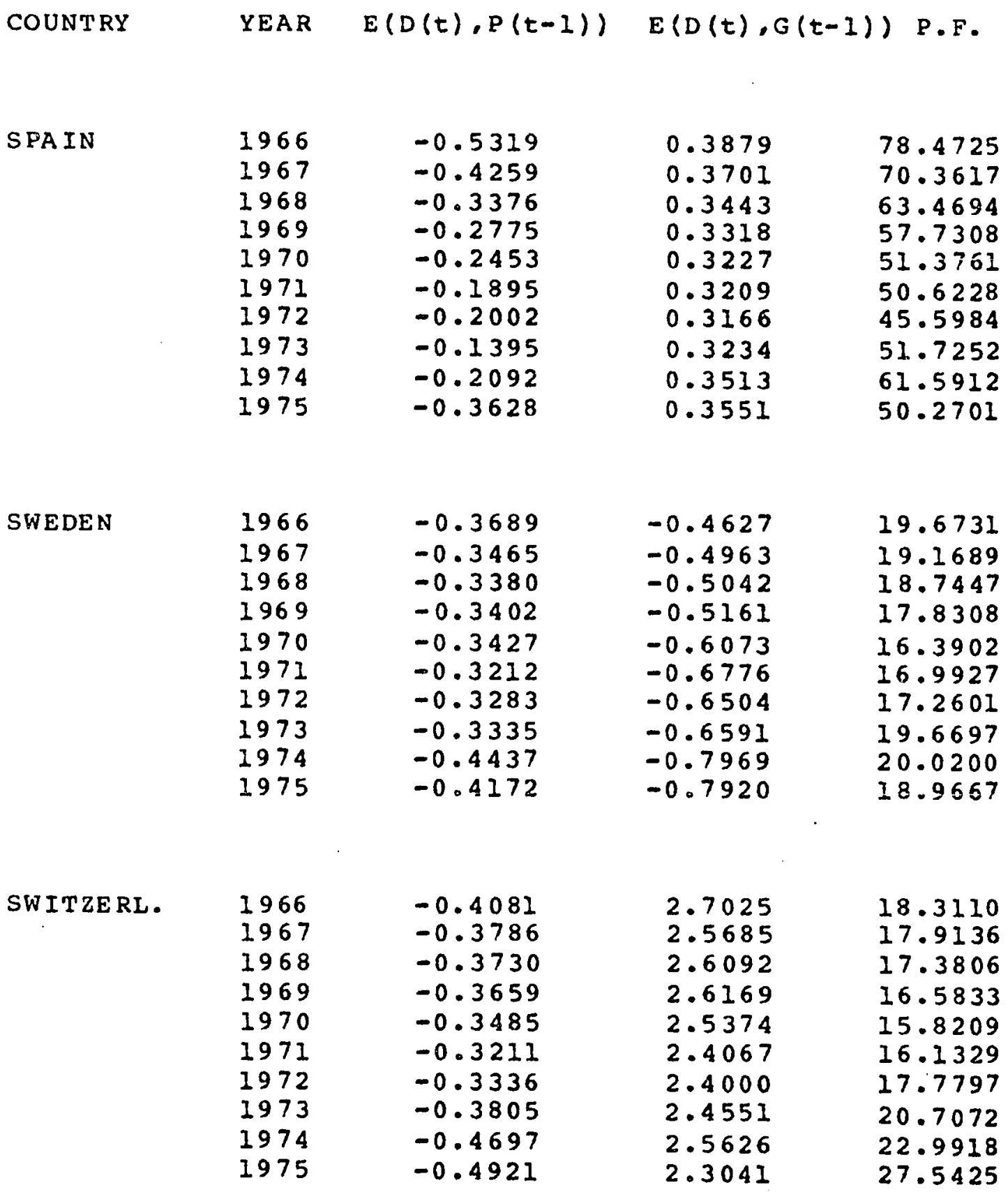


TABLE III.23 CONTD.

VARIOUS ELASTICITIES OF DEMAND: MODEL I. 5

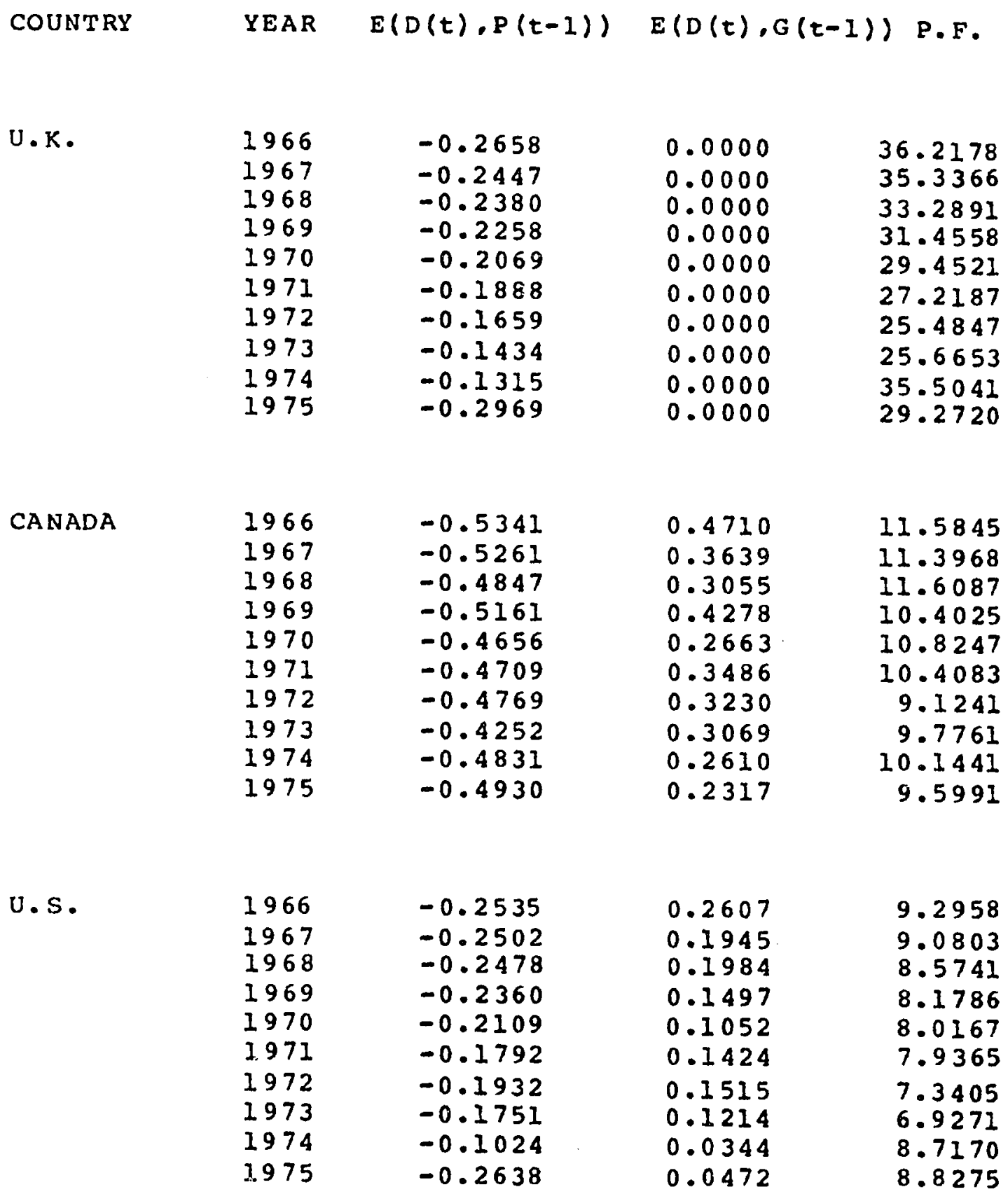


TABLE III.24

AVERAGE ELASTICITIES FOR DIFFERENT RANGES OF P.F.: MODEL I.5

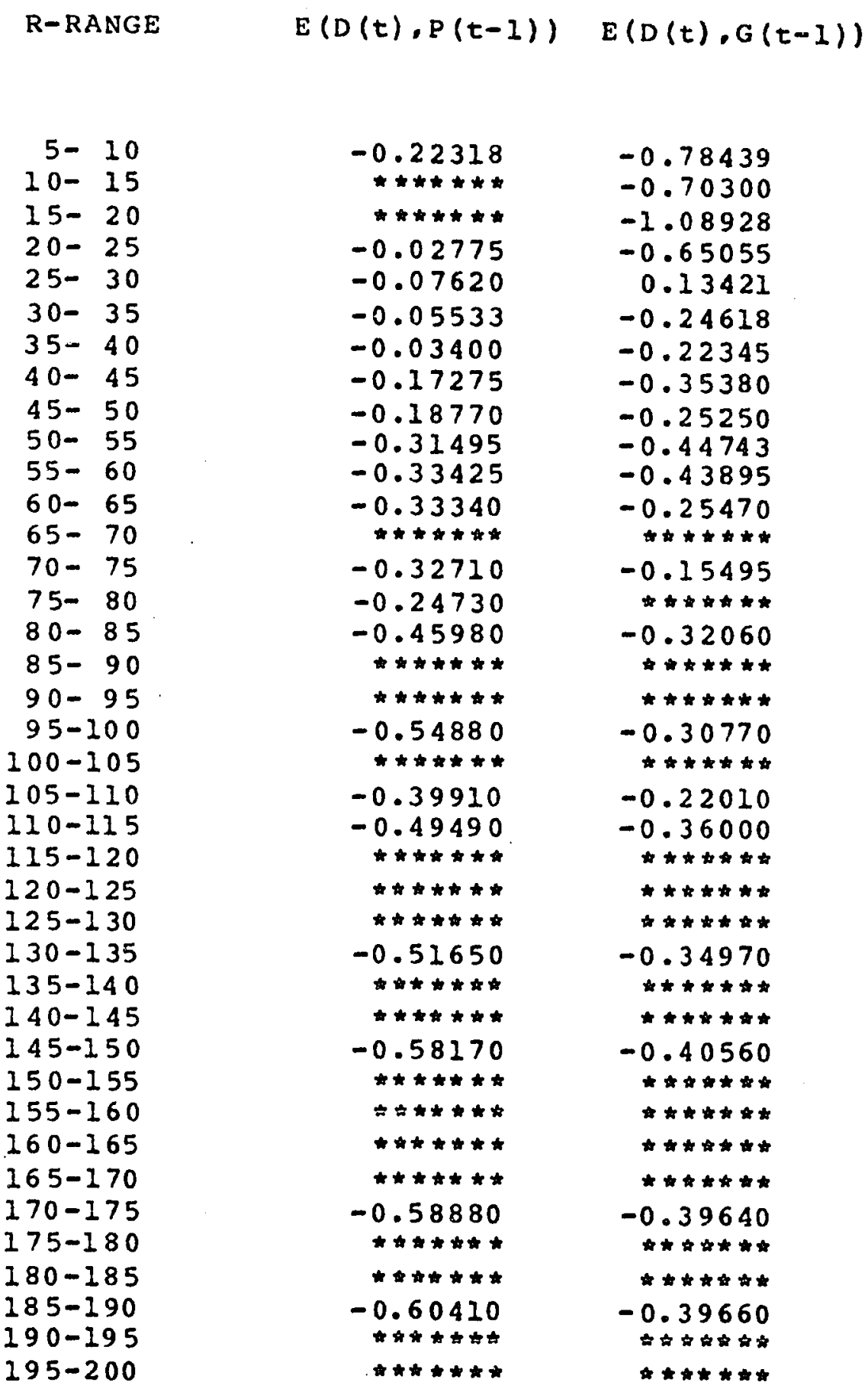


practical observations. Such negative coefficients suggest that an increase in the per capita GNP is associated with a decrease in demand intensity which contradicts with figures II.1. The positive elasticity values of around 4 , calculated for Norway, are excessively high. The figures in chapter II show an almost equal growth rates of both demand Intensity and GNP per capita implied by the almost parallel trends of their graphs. This suggests an almost unitary positive elasticity. The average elasticitier displayed in table III.II reflect the unreasonable behavior just discussed. It is posstble that the estimates were strongly biased under the influence of other variables in the model. For the above reasons, the other models were formulated as described earlier in the chapter and the results were as follows:

Results of Model I.I

The annual values of $E(D(t), G(t))$ and their averages for the different ranges of P.F. as calculated from model I.I are displayed in tables III.I3 and III.I4. As can be seen from the tables, the elasticities were still mostly negative despite the U.K. and Canada showing positive values close to the expected magnitudes.

Results OE Model I.2

Tables III.I 6 and III.I 7 contain the annual elasticity values and their averages for ranges of P.F. as calculated 
from model I.2. Referring to table III.16, the following observations can be made:

Positive demand elasticities of reasonable magnitudes appeared for Austria, Belgium, Italy, the Netherlands, Norway and the U.K. The coefficients were negligible for the U.S., zero for sweden, positive but low for spain and negative for the rest.

Referring to the expected "rational" economic behavior, the results of this model are improved over the previous two, st111 not accepatble yet.

\section{THE $G(t-I)$ ELASTICITY OF DEMAND}

Due to the unacceptable findings about $E(D(t), G(t))$ that were described in the preceding section, it was decided to examine $E(D(t), G(t-1)$ ) for a possible delayed influence of the per capita GNP. The results are described in what follows:

\section{Results of Model I}

Table III.I0 shows that the elasticity values with respect to per capita GNP with a one year time lag are positive for six out of the fifteen OECD countries, zero for three and negative for six of them. As can be seen from table III.I, the extremely large negative values calculated for Luxembourg are obviously a consequence of Including the triplet $(G(t-1), G(t)$ and $g)$ in the estimated model. As it was explained earlier, other steps generated by the stepwise 
regression program which did not include the triplet were statistically highly insignificant.

The influence of the large negative coefficients of Luxembourg is reflected in the values corresponding to the P. F-ranges between 15 and 25 in table III.II. Ignoring this range of P.F., table III.ll indicates a more reasonable behavior for the influence of per capita GNP on demand.

It can also be seen from the table that $E(D(t), G(t-1))$ does not appear to be a function of P.F.. rather it fluctuates around a fixed value. For the above reason, the average elasticities were averaged giving a value of $.68 \pm$ .35 .

\section{Results of Model I.3}

The removal of current variables from model I resulted in the annul elasticities of demand given in table III.I9. We see from the table that nine countries showed positive elasticities, four countries showed negative elasticities and two countries showed zero elasticities. The averages over the intervals of P.F. are displayed in table III.20 and again indicate a rather constant reference value. The overall average elasticity calculated by this model was.73t .29.

Results of Model I.4

The annual elasticities and the $1 \mathrm{r}$ averages, as caculated from model I.4 are displayed in table III.2I and III.22. The tables show predominantly positive elasticity 
coefficients. Actually, only Denmark showed negative elasticity values. The overall average elasticity calculated from table III.22 was .96士.29.

Results of Model I.5

As may be seen from tables III.23 and III.24, The specific formulation of model I.4 reduced the overall average elasticity to $.47 \pm .35$.

It was concluded from the above analysis that the elasticity of demand intensity, averaged over countries, with respect to the per capita GNP lagged by one year, falls in the range $0.7 \pm 0.3$. 
CHAPTER IV.

\author{
CROSS SECTION ANALYSIS, MODEL VALIDATION AND \\ CONCLUSIONS OF THE REGRESSION ANALYSIS
}

\title{
CROSS SECTION ANALYSIS
}

The time series analysis described in chapter III

indicated rational functional dependence of the elasticity of demand per GNP, averaged over the countries considered, on the ratio of current price to current per capita GNP, P.F. This finding suggested that P.F. itself might be a good explanatory variable of demand behavior within defined Iimits. The investigation was therefore further extended by analyzing the data of the various countries cross sectionally for each of the years 1965-1975.

Cross sectional plots of $D(t)$ versus the current price, $P(t)$, were first considered. Figure IV.l depicts a scatter plot of the data for the year 1970. It is clear that the figure does not indicate the regular downward sloping pattern expected for the relationsifp between price and demand.

The annual cross sectional data of $D(t)$ versus $P(t)$ were fitted via oLs for the various functional forms. The results for the years 1970 and 1975 are displayed in figures IV.2 and IV.3 and tables IV.I and IV.2. These results are representative of the findings for the rest of the years and 


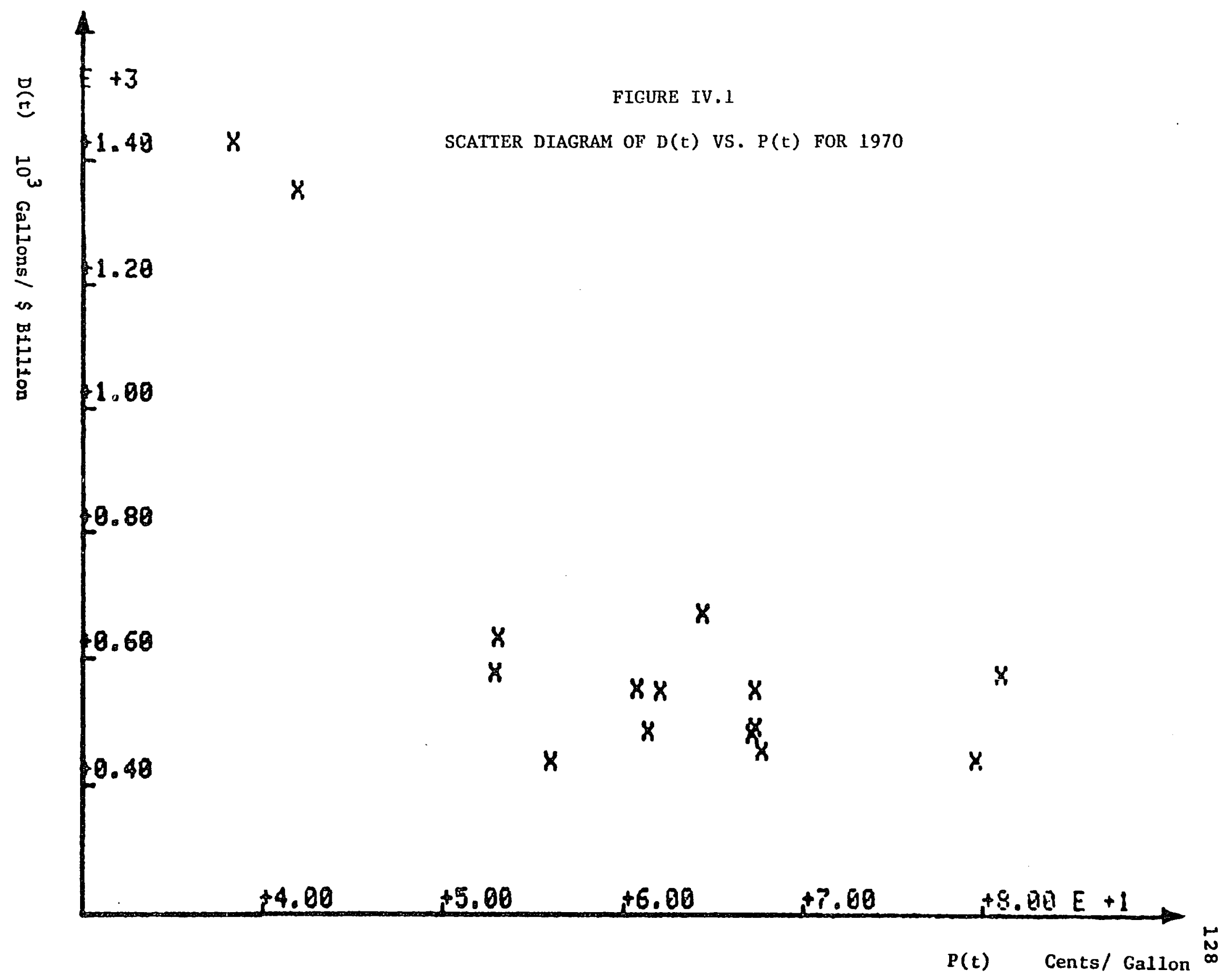


TABLE IV.I

CURVE FIT OF $D(t)$ VS. $P(t)$ FOR 1970

EQUATION

$\mathrm{Y}=\mathrm{A} \star \mathrm{X}$

$Y=A+B \star X$

$Y=A \star E X P(B \star X)$

$Y=1 /(A+B * X)$

$\mathbf{Y}=\mathbf{A}+\mathbf{B} / \mathbf{X}$

$Y=A+B * \operatorname{LOG}(X)$

$Y=A * X^{B}$

$Y=X /(A+B * X)$
A

9.51184

1862.65810

2471.48974

$-0.00006$

$-565.81487$

5706.21105

209510.82327

$-0.10417$
B

0.00000

$-19.79267$

$-0.02304$

0.00003

71602.62938

$-1234.26515$

$-1.42836$

0.00352
R-SQUARE

INSIGNIF .

0.56721

0.62365

0.55373

0.76133

0.67168

0.73893

0.80276
MAX DEVIATION

1063.03549

325.67034

412.46303

504.12056

276 . 35351

301.40974

345.65480

387.41893 
FIGURE IV.2

BEST FIT OF $D(t)$ VS. $P(t)$ FOR 1970

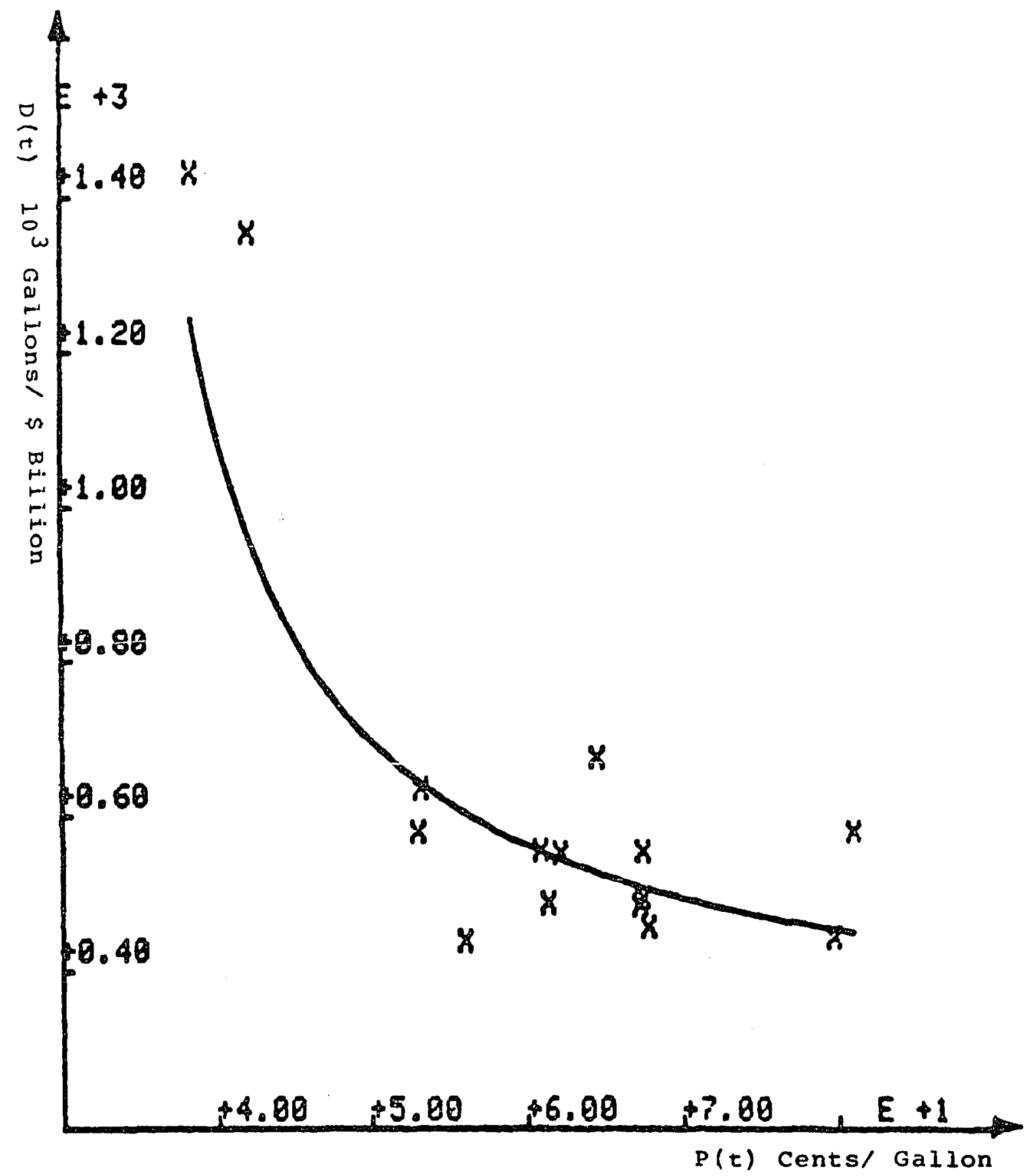


TABLE IV. 2

CURVE FIT OF D(t) VS. $P(t)$ FOR 1975

\section{EQUATION}

$$
\begin{aligned}
& Y=A * X \\
& Y=A+B \star X \\
& Y=A * \operatorname{EXP}(B \star X) \\
& Y=1 /(A+B \star X) \\
& Y=A+B / X \\
& Y=A+B \star \operatorname{LOG}(X) \\
& Y=A * X \\
& Y=X /(A+B \star X)
\end{aligned}
$$

$$
\text { A }
$$$$
7.58193
$$$$
1770.02411
$$$$
2092.97356
$$$$
0.00025
$$$$
-126.27528
$$$$
4876.65543
$$$$
60460.28737
$$$$
-0.08093
$$

B

0.00000

$-12.87228$

$-0.01390$

0.00002

64278.95194

$-951.15938$

$-1.02915$

0.00263
R-SQUARE

INSIGNIF

0.64563

0.69827

0.65032

0.80425

0.73682

0.78647

0.83678
MAX DEVIATION

1077.38940

361.02049

280.88550

357.71053

284.57220

328.64902

253.49503

255.03143 
FIGURE IV. 3

BEST FIT OF $D(t)$ VS. $P(t)$ FOR 1975

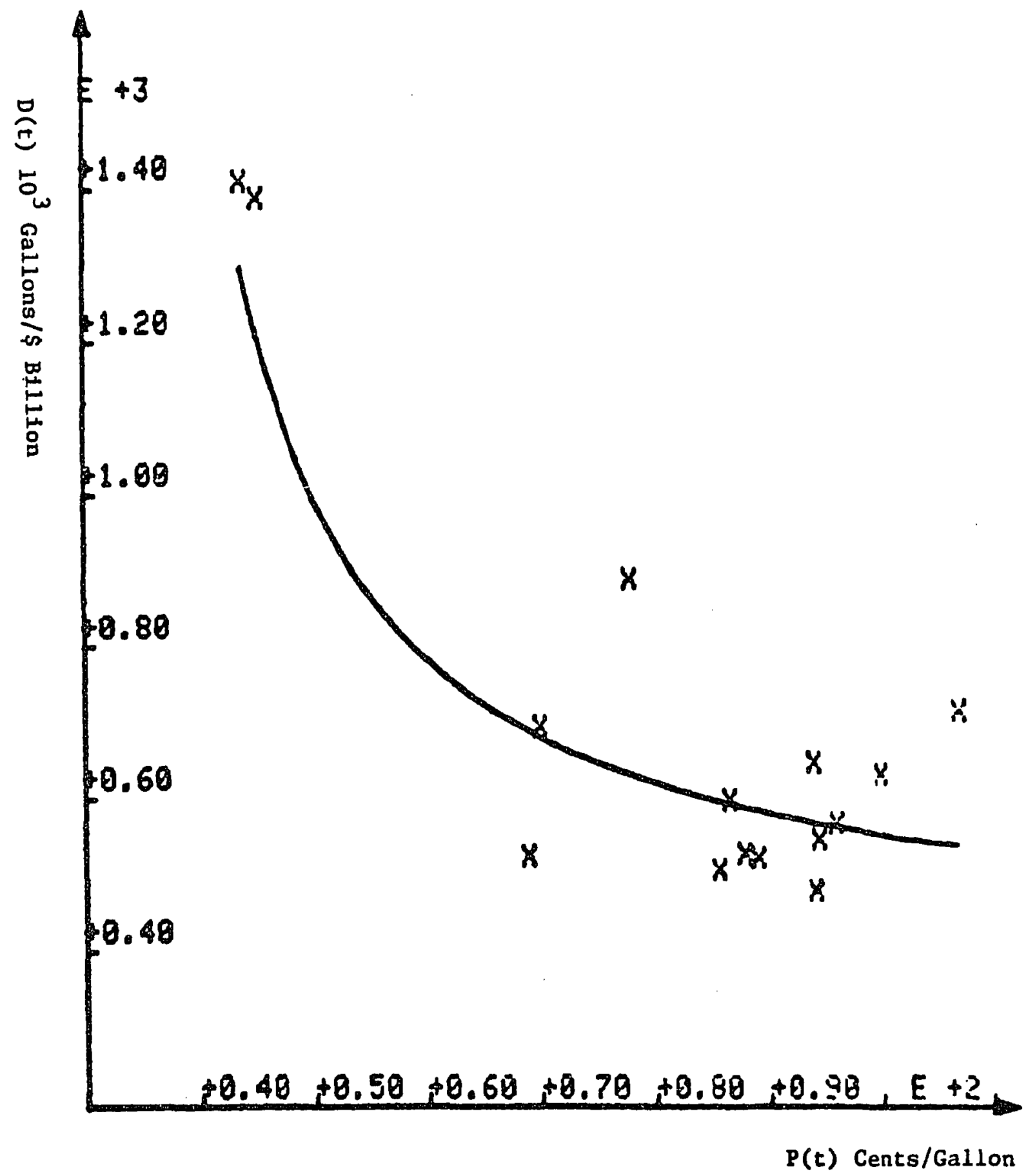


conflrm the lack of good fit whlch was originally apparent from a mere visual inspection of figure IV.l.

In the next step of the analysis, $D(t)$ was regressed against the price factor P.F. for the same functional forms. Again, the data showed no good fit for the various years as indicated by the results of the regression for the year 1970 displayed in figures IV.4 and IV.5 and table IV.3.

When demand per capita, $D C(t)$, was introduced instead of the demand per GNP, the plots showed the expected rational economic behavior. Figure IV.6 depicts a scatter plot of $D C(t)$ versus $P . F$. taken cross sectionally for the fifteen OECD countries for the year 1965. The behavior depicted in the figure is representative of that found for a 11 years between 1965 and 1975.

The cross section data of $D C(t)$ were regressed against P.F. for the years 1965 through 1975, employing the various functional forms previously described. The results of the OLS curve fittings for the years 1965,1970 and 1975 are given in tables IV. 4 through IV.6 and figures IV.7 through IV.9. An analysis of the fitted equations for the vartous years did not indicate a regular detectable pattern of a temporal shift in the cross sectional demand curve.

Table IV.7 summarizes the curve fitting results of $D C(t)$ versus P.F. for the years 1965 through 1975. The table shows that the exponential function gave quite satiofactory results for all the years with R-SQR. values above 0.90 . 


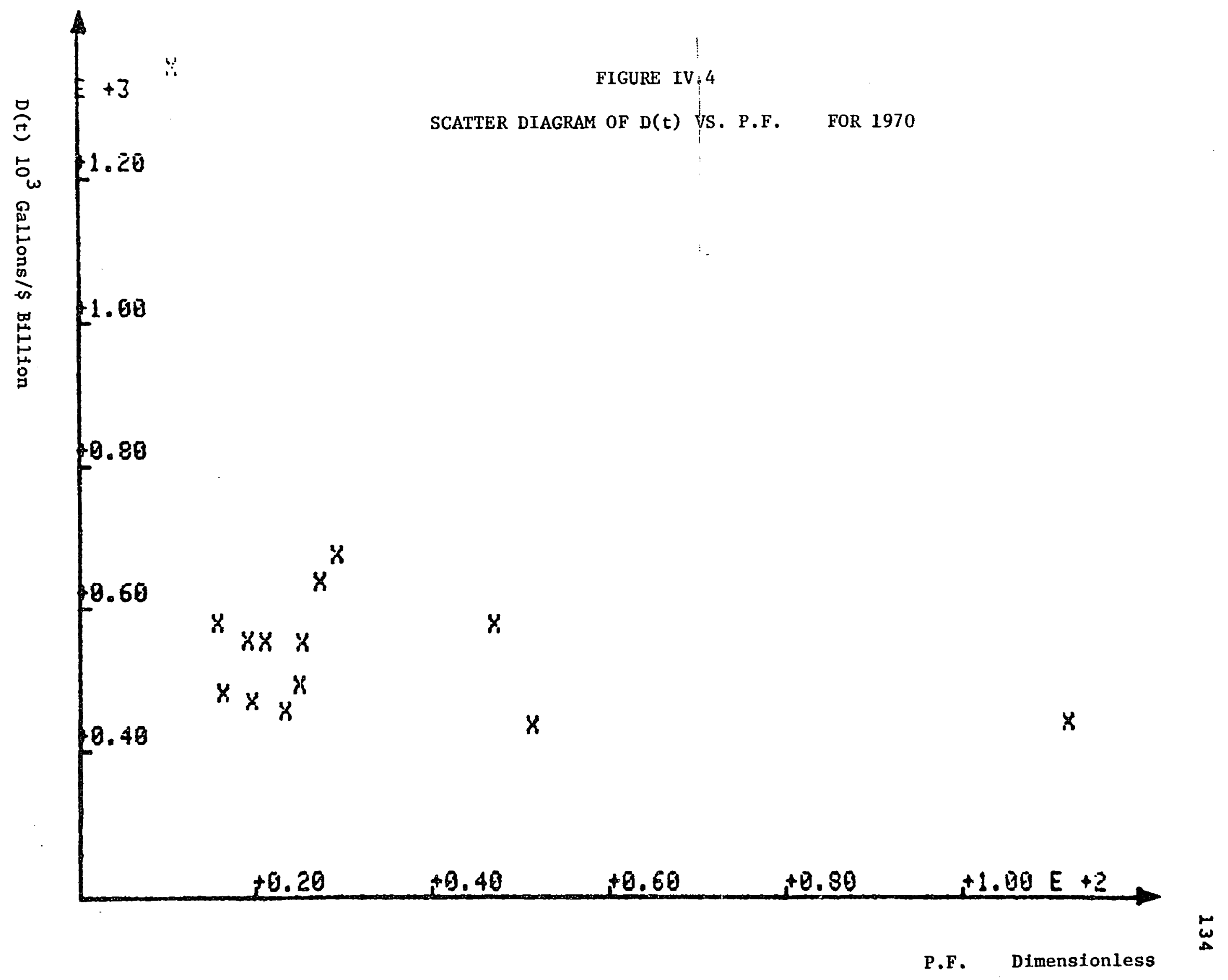


FIGURE IV.5

BEST FIT OF $D(t)$ VS. P.F. FOR 1970

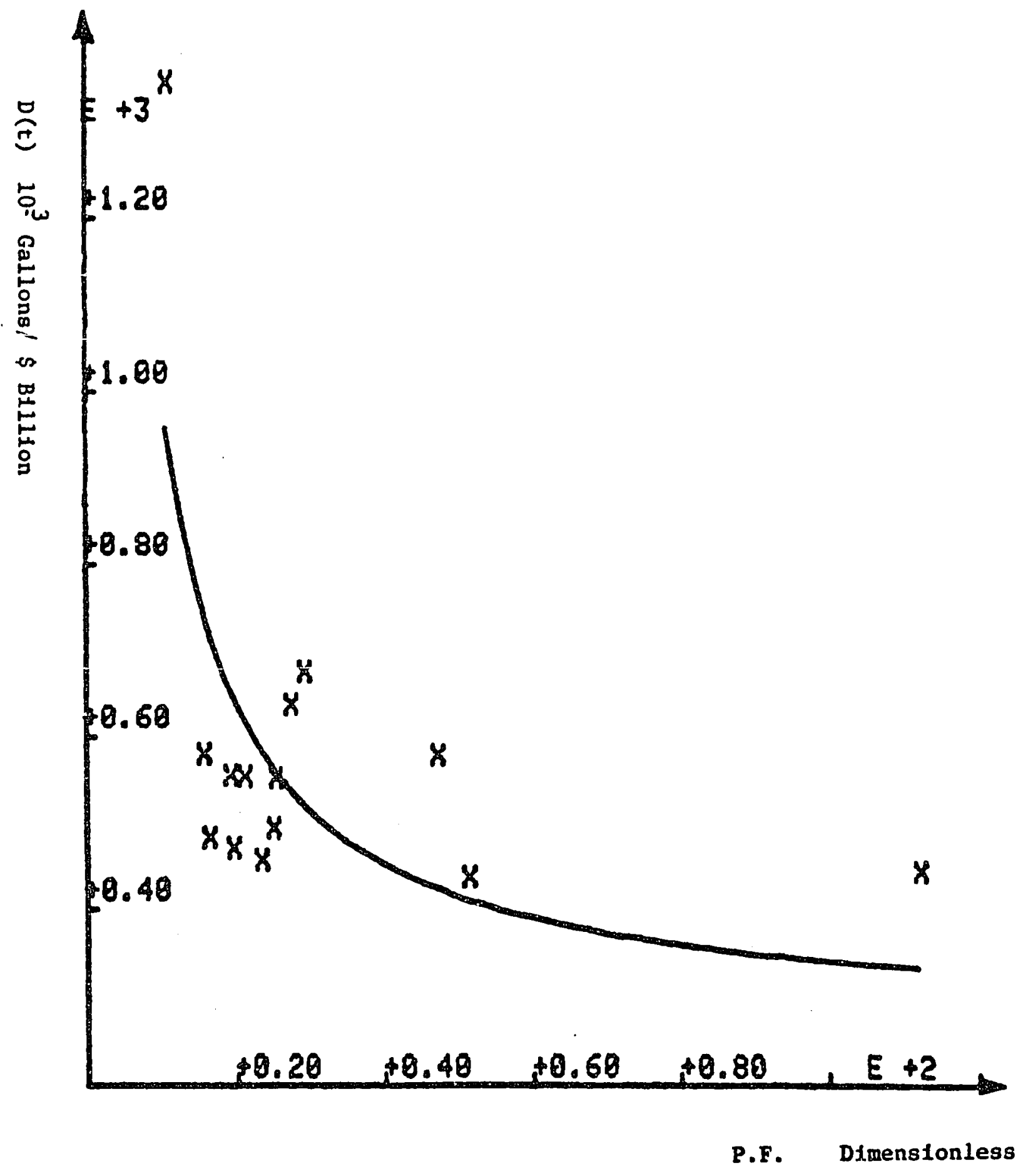


TABLE IV. 3

CURVE FIT OF $D(t)$ VS. P.F. FOR 1970

EQUATION

$$
\begin{aligned}
& Y=A \star X \\
& Y=A+B \star X \\
& Y=A \star E X P(B \star X) \\
& Y=I /(A+B \star X) \\
& Y=A+B / X \\
& Y=A+B \star L O G(X) \\
& Y=A \star X B \\
& Y=X /(A+B \star X)
\end{aligned}
$$

A

10.41256

683.41394

643.43928

0.00162

263.79402

1226.69596

1282.06099

$-0.01221$
B

0.00000

$-2.95721$

$-0.00422$

0.00001

7505.95831

$-194.92058$

$-0.25190$

0.00236
R-SQUARE

INSIGNIF

0.10845

0.09783

0.06846

0.46007

0.24189

0.24183

0.44228
MAX DEVIATION

1238.99404

700.30786

737.00539

760.80552

394.52492

589.28723

648.08484

542.64534 


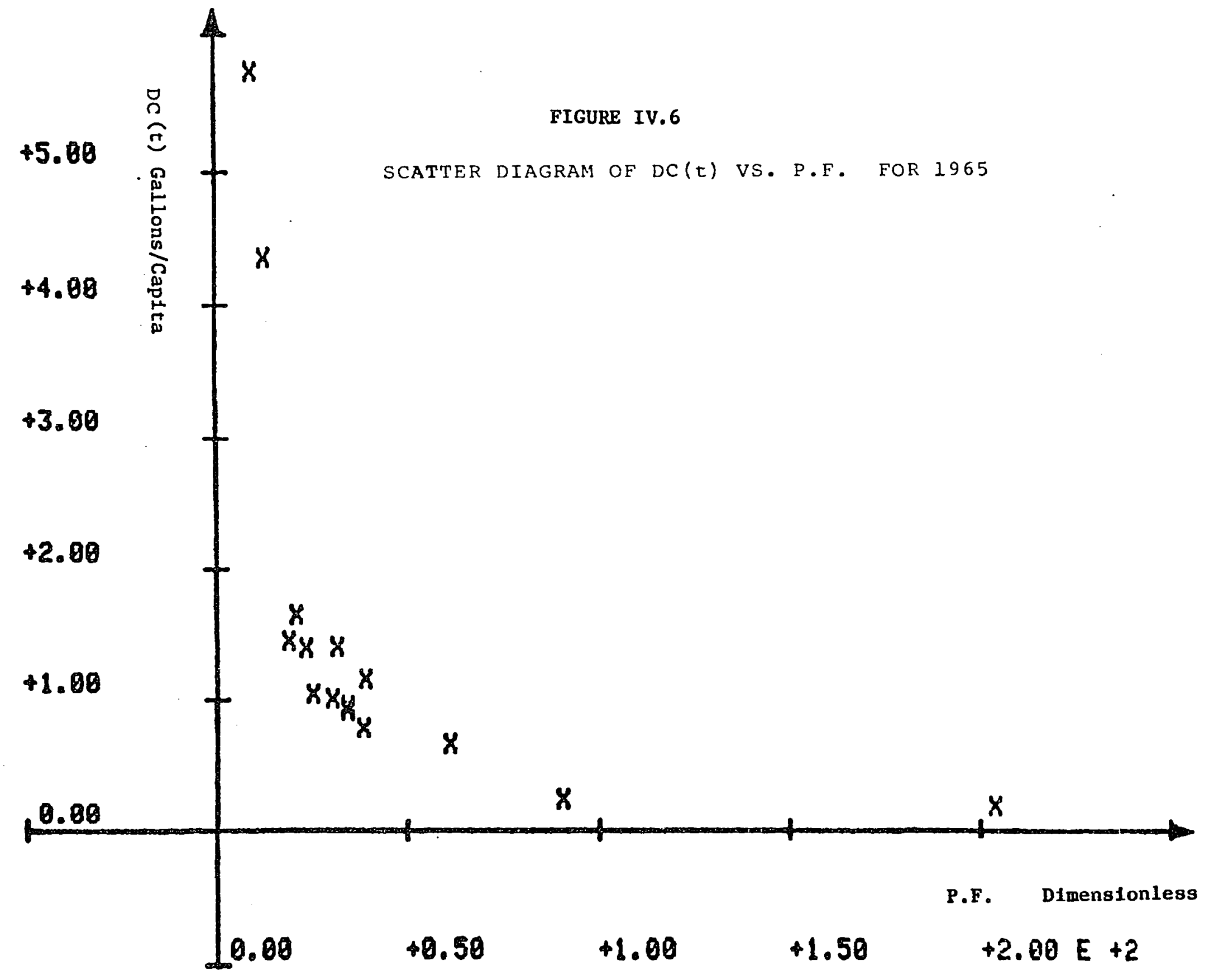


TABLE IV. 4

CURVE FIT OF DC(t) VS. P.F.(t) FOR 1965

EQUATION

$\mathbf{Y}=A \star X$

$Y=A+B * X$

$Y=A \star \operatorname{EXP}(B \star X)$

$Y=I /(A+B * X)$

$\mathbf{Y}=\mathrm{A}+\mathrm{B} / \mathrm{X}$

$Y=A+B \star \operatorname{LOG}(X)$

$Y=A \star X^{B}$

$Y=X /(A+B \star X)$
A

$$
0.00868
$$

2.19480

2.08819

0.05143

$-0.65631$

6.91988

58.17761

$-39.25105$

\section{B}

$$
0.00000
$$

$-0.01488$

$-0.01493$

0.02957

57.61963

$-1.54400$

$-1.14451$

2.86733
R-SQUARE

INSIGNIF.

0.22642

0.27431

0.61024

0.91273

0.58458

0.26178

INSIGNIF .
MAX DEVIATION
5.64058
3.67758
3.93307
2.80554
0.91143
2.33640
1.47721
9.79562 
FIGURE IV. 7

BEST FIT OF DC(t) VS. P.F. FOR 1965

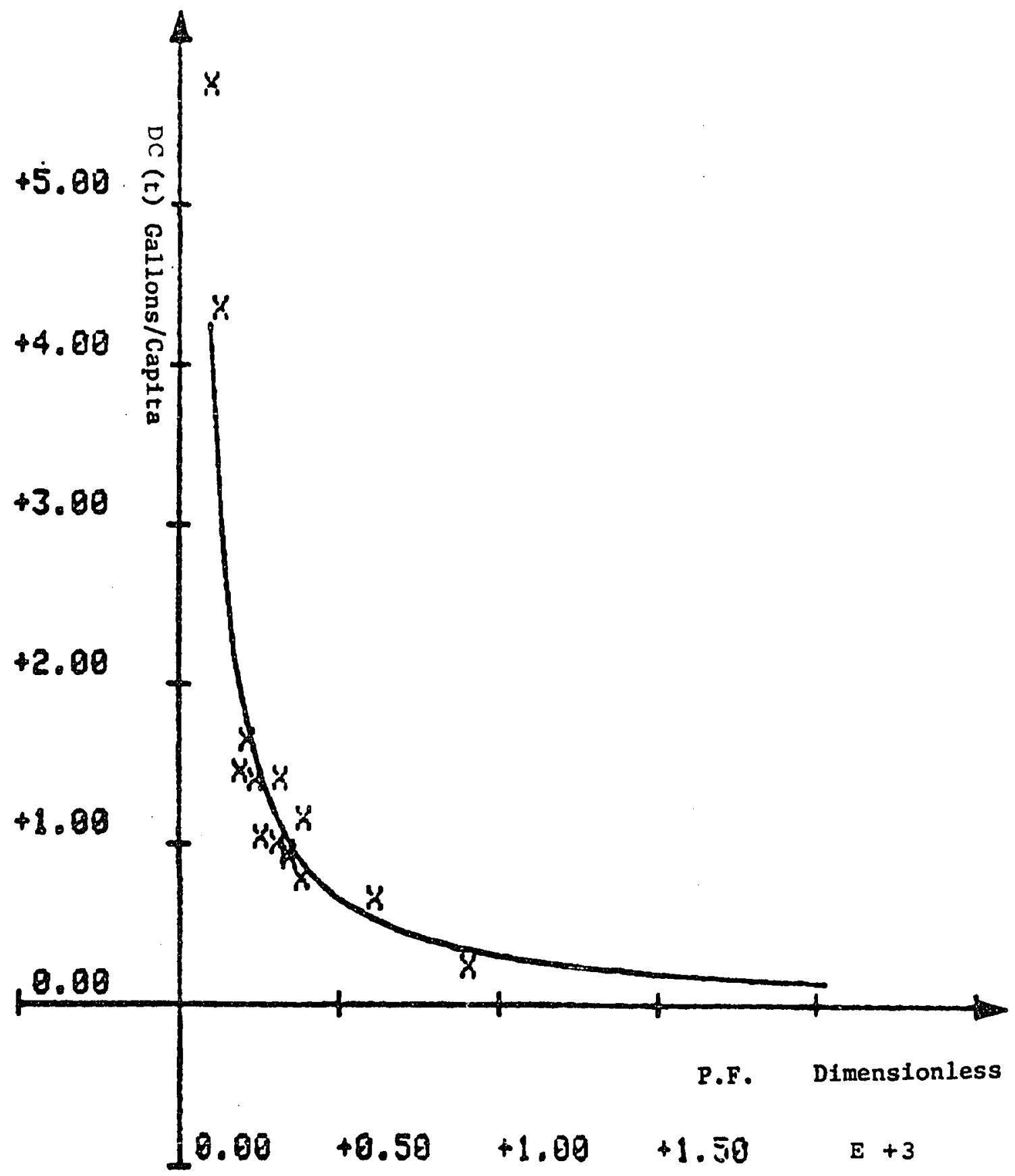


TABLE IV. 5

CURVE FIT OF DC(t) VS. P.F. (t) FOR 1970

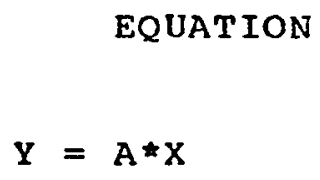


FIGURE IV. 8

BEST FIT OF DC(t) VS. P.F. FOR 1970

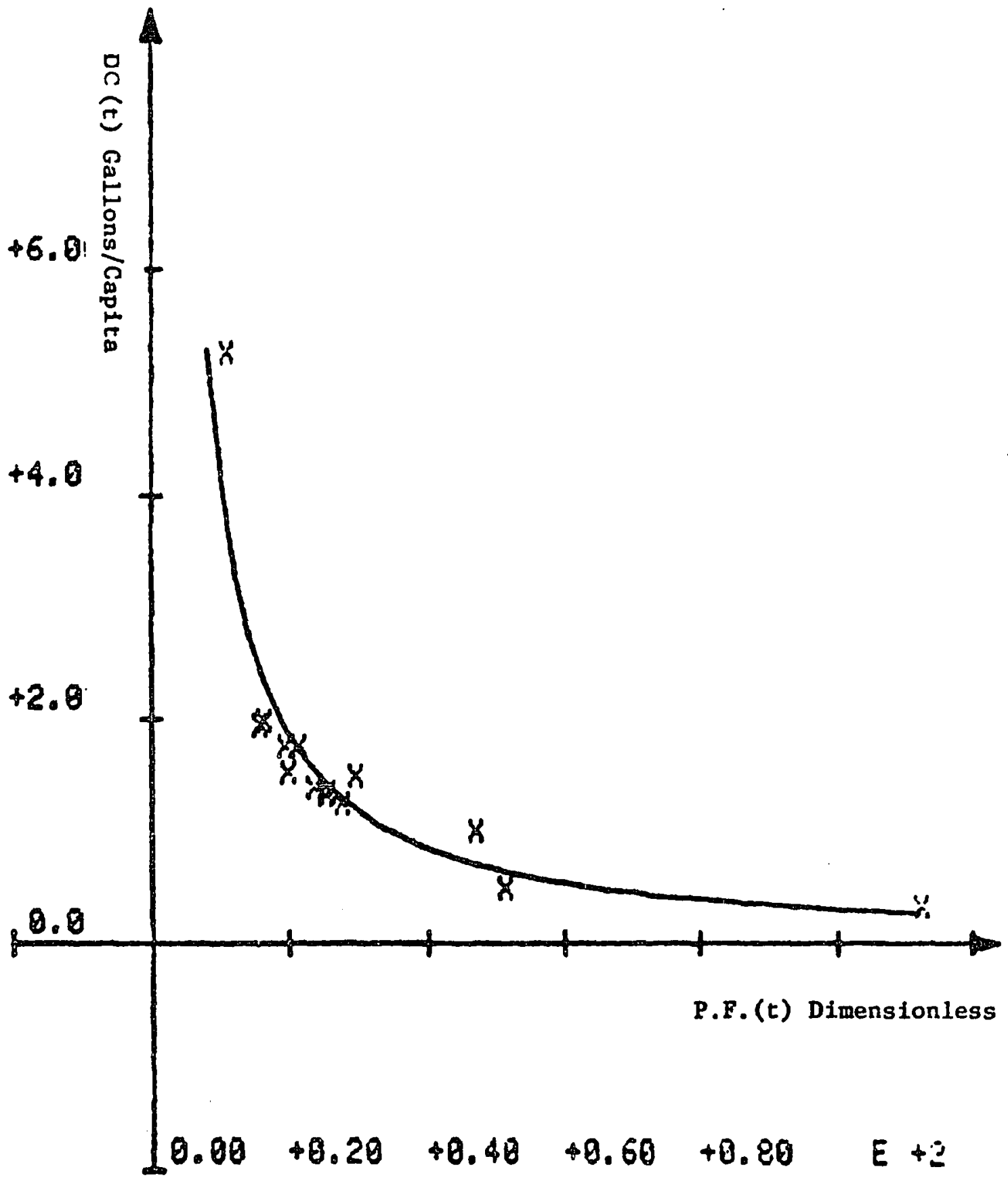


TABLE IV. 6

CURVE FIT OF DC(t) VS. P.F. FOR 1975

EQUATION

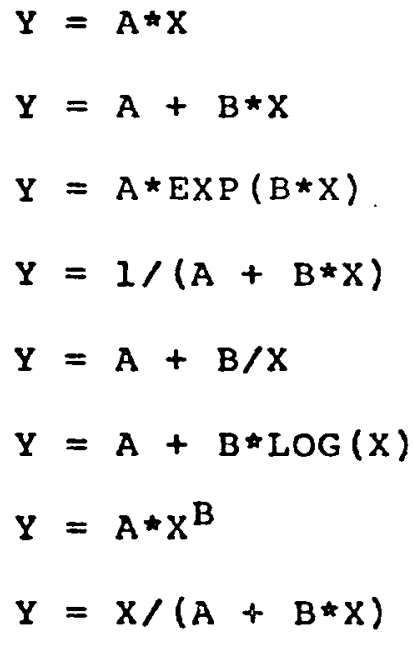

$$
\text { A }
$$

0.03174

4.18401

4.40461

$-0.00178$

$-0.40680$

11.64299

66.40670

$-11.10941$
B

$$
0.00000
$$$$
-0.05274
$$$$
-0.02508
$$$$
0.01940
$$$$
66.22100
$$$$
-2.75993
$$$$
-1.06464
$$$$
1.13390
$$

R-SQUARE

INSIGNIF .

0.39222

0.50680

0.90651

0.95943

0.76388

C.94933

INSIGNIF .
MAX DEVIATION

7.29278

3.85460

4.04325

1.67142

0.81158

1.94094

1.03858

49.03310 
FIGURE IV. 9

BEST FIT OF DC(t) VS. P.F. FOR 1975

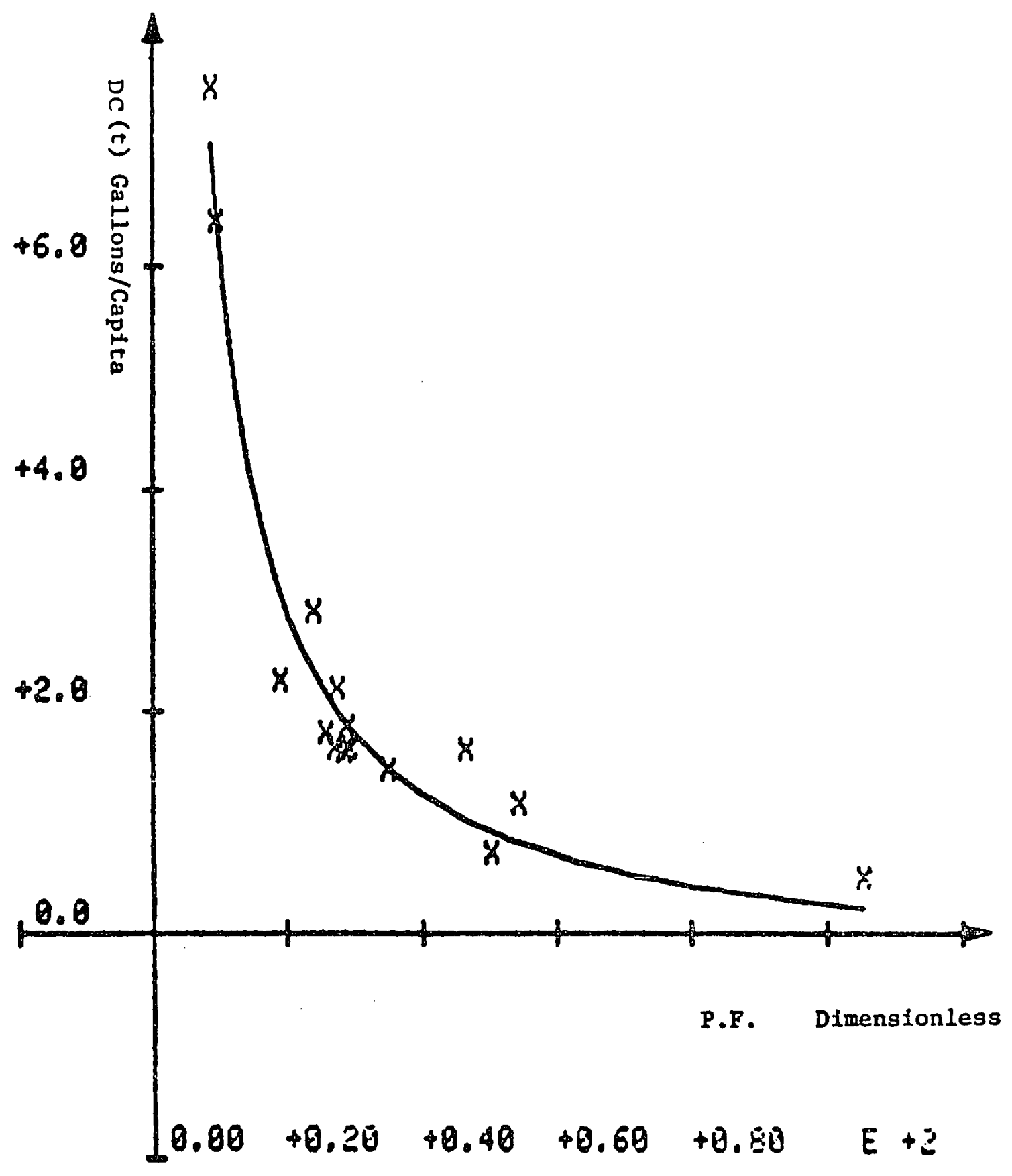


Despite the fact that the exponential function ranked second best for all but one of the eleven years, as may be seen from table IV.7, it was adopted because of its perfect interpretability. The exponent of P.F. is nothing but the elasticity of $D C(t)$ with respect to $P . F$.

The exponents of P.F. estimated for the various years were averaged, yielding an average elasticity of $-1.125 \pm .023$. This value was used as the measure of the elasticity of per capita demand to the price factor P.F. In various countries.

It was concluded from the preceding cross section analysis that the per capita demand in the various countries examined in the present work displays rational economic behavior versus the corresponding price factor P.F. The demand function was thus assumed exponential in P.F. with an elasticlty of $-1.125 \pm 0.023$.

Contrary to the convention followed in the economics literature, the price related variable (P.F.) was plotted on the horizontal axis.

MODEL VALIDATION

The findings of the time series and cross section analyses described in Chapter III and the preceding section of this chapter were used for retrospective forecasting of the demand for motor gasoline in the OECD countries that were not included in the analysis, viz. France, Ireland and Japan. 
TABLE IV.7

CROSS-SECTIONAL DEMAND ESTIMATES: VARIOUS COUNTRIES

\begin{tabular}{|c|c|c|}
\hline YEAR & ESTIMATED FUNCTION & $\mathrm{R}-\mathrm{SQR}$ \\
\hline 1965 & $\begin{array}{l}D^{\prime}=-0.656+(57.62 / \text { P.F. }) \\
D^{\prime}=58.178(\text { P.F. })-1.145\end{array}$ & $\begin{array}{l}0.913 \\
0.862\end{array}$ \\
\hline 1966 & $\begin{array}{l}D^{\prime}=54.983(\text { P.F. })-1.128 \\
D^{\prime}=-0.640+(56.11 / \text { P.F. })\end{array}$ & $\begin{array}{l}0.922 \\
0.916\end{array}$ \\
\hline 1967 & $\begin{array}{l}D^{\prime}=-0.641+(56.01 / \text { P.F. }) \\
D^{\prime}=55.915(\text { P.F. })-1.128\end{array}$ & $\begin{array}{l}0.931 \\
0.928\end{array}$ \\
\hline 1968 & $\begin{array}{l}D^{\prime}=-0.708+\left(57.19 / P_{0} F_{.}\right) \\
D^{\prime}=57.028(\text { P.F. })-1.134\end{array}$ & $\begin{array}{l}0.924 \\
0.923\end{array}$ \\
\hline 1969 & $\begin{array}{l}D^{\prime}=-0.706+\left(55.36 / P_{.} F_{0}\right) \\
D^{\prime}=52.116(\text { P.F. })-1.11\end{array}$ & $\begin{array}{l}0.935 \\
0.929\end{array}$ \\
\hline 1970 & $\begin{array}{l}D^{\prime}=-0.836+(57.463 / \text { P.F. }) \\
D^{\prime}=56.678\left(P_{. F}\right)-1.140\end{array}$ & $\begin{array}{l}0.916 \\
0.872\end{array}$ \\
\hline 1971 & $\begin{array}{l}D^{\prime}=-0.796+\left(58.643 / P_{. F}\right) \\
D^{\prime}=60.348(\text { P.F. })-1.140\end{array}$ & $\begin{array}{l}0.939 \\
0.932\end{array}$ \\
\hline 1972 & $\begin{array}{l}D^{\prime}=-0.625+\left(56.035 / P . F_{.}\right) \\
D^{\prime}=60.939 \text { (P.F.) }-1.130\end{array}$ & $\begin{array}{l}0.969 \\
0.943\end{array}$ \\
\hline 1973 & $\begin{array}{l}D^{\prime}=-0.313+\left(57.023 / P_{.} F_{0}\right) \\
D^{\prime}=76.312(\text { P.F. })-1.147\end{array}$ & $\begin{array}{l}0.971 \\
0.944\end{array}$ \\
\hline 1974 & $\begin{array}{l}D^{\prime}=-0.317+\left(65.359 / P_{. F}\right) \\
D^{\prime}=69.391(\text { P.F. })-1.071\end{array}$ & $\begin{array}{l}0.964 \\
0.923\end{array}$ \\
\hline 1975 & $\begin{array}{l}D^{\prime}=-0.407+\left(66.22 / P_{. F}\right) \\
D^{\prime}=66.407 \text { (P.F.) }-1.065\end{array}$ & $\begin{array}{l}0.959 \\
0.949\end{array}$ \\
\hline
\end{tabular}


Starting with the 1965 demand level, the annual values of P.F. and the GNP were subst1tuted in the various formulae estimated in the thesis to predict the demand levels for the succeeding years through 1975. These elasticity functions, estimated by the time series analysis, are repeated below for the ease of reference:

$E I=-.74+(24.37 / P \cdot F \cdot)$

$E 2=1.003-0.315 \mathrm{ln} \cdot(P . F$.

$E 3=P \cdot F \cdot /(-I 53 \cdot 26-0.719$ P.F. $)$

$[4.5]$

The prediction results were as follows:

Forecasts Based on Time Series Results

The three elasticity functions estimated by time series analysis were used to calculate the annual intensity of demand for motor gasoline given the corresponding values of current and lagged GNP and prices. Two of the three estimated exponents of the lagged GNP per capita, viz. 0.4 and 0.7 , were used in the calculations.

The demand levels forecasted by the three elasticity functions for each of the two exponents of $G(t-1)$ for France, Ireland and Japan are displayed in tables IV.8 through IV.10, respectively.

Tables IV.8 through IV.I0 indicate the following:

1. France: The G(t-1) exponent of 0.4 yielded better results reflected by the lower percentage 
TABLE IV. 8

TIME SERIES FORECASTS FOR FRANCE

(LAGGED GNP EXPONENT $=0.7)$

\begin{tabular}{|c|c|c|c|c|c|c|c|}
\hline \multicolumn{2}{|r|}{ ACTUAL } & \multicolumn{6}{|c|}{ FORECASTS } \\
\hline YEAR & $D(t)$ & $\mathrm{D} l(t)$ & ERROR 1(\%) & D2 $(t)$ & ERROR 2(\%) & D3 $(t)$ & ERROR $3(\%)$ \\
\hline $\begin{array}{l}1968 \\
1969 \\
1970 \\
1971 \\
1972 \\
1973 \\
1974 \\
1975\end{array}$ & $\begin{array}{l}495.59 \\
490.31 \\
499.21 \\
514.31 \\
530.08 \\
546.55 \\
512.99 \\
541.82\end{array}$ & $\begin{array}{l}498.38 \\
512.71 \\
524.39 \\
548.34 \\
567.85 \\
614.28 \\
659.47 \\
671.40\end{array}$ & $\begin{array}{l}00.01 \\
04.57 \\
05.04 \\
06.62 \\
07.13 \\
12.39 \\
28.55 \\
23.93\end{array}$ & $\begin{array}{l}499.47 \\
516.27 \\
531.53 \\
556.91 \\
575.73 \\
591.59 \\
626.18 \\
632.86\end{array}$ & $\begin{array}{l}00.01 \\
05.30 \\
06.47 \\
08.28 \\
08.61 \\
08.24 \\
22.06 \\
16.80\end{array}$ & $\begin{array}{l}500.94 \\
520.25 \\
538.24 \\
564.64 \\
583.13 \\
581.85 \\
609.79 \\
612.75\end{array}$ & $\begin{array}{l}00.01 \\
06.11 \\
07.82 \\
09.79 \\
10.01 \\
06.46 \\
18.87 \\
13.09\end{array}$ \\
\hline \multicolumn{8}{|c|}{ (LAGGED GNP EXPONENT $=0.4)$} \\
\hline $\begin{array}{l}1968 \\
1969 \\
1970 \\
1971 \\
1972 \\
1973 \\
1974 \\
1975\end{array}$ & $\begin{array}{l}495.59 \\
490.31 \\
499.21 \\
514.31 \\
530.08 \\
546.55 \\
512.99 \\
541.82\end{array}$ & $\begin{array}{l}490.47 \\
498.82 \\
504.58 \\
517.27 \\
528.06 \\
564.07 \\
589.66 \\
596.42\end{array}$ & $\begin{array}{l}-0.01 \\
01.74 \\
01.08 \\
00.58 \\
-0.38 \\
03.21 \\
14.95 \\
10.08\end{array}$ & $\begin{array}{l}491.54 \\
502.28 \\
511.45 \\
525.36 \\
535.39 \\
543.24 \\
559.89 \\
562.18\end{array}$ & $\begin{array}{l}-0.01 \\
02.44 \\
02.45 \\
02.15 \\
01.00 \\
-0.61 \\
09.14 \\
03.67\end{array}$ & $\begin{array}{l}492.99 \\
506.16 \\
517.90 \\
532.65 \\
542.27 \\
534.29 \\
545.24 \\
544.32\end{array}$ & $\begin{array}{l}-0.01 \\
03.23 \\
03.74 \\
03.57 \\
02.30 \\
-2.24 \\
06.29 \\
00.46\end{array}$ \\
\hline
\end{tabular}


deviations from the actual values. The least errors were provided by the elasticity function E3. The errors ranged from -2.248 to +6.298 , with all but one deviation being positive.

2. Ireland: The best forecasts for Ireland were provided by the elasticity function El together with an exponent of 0.4 for $G(t-1)$. S1x of the errors were positive and two assumed negative values. The percentage deviation from the actual demand levels ranged between -3.588 and +38 . It may be noted that the elasticity function E3 together with a $G(t-1)$ exponent of 0.7 , which gave the best results for France, yielded an error in the range of -10.788 to +0.018 in the case of I reland.

3. Japan: The elasticity function E3 together with a $G(t-1)$ exponent of 0.4 provided the least forecast errors. All forecasted values were positively biased with percentage errors ranging from +4.768 to +13.318

Although three countries is too small a sample to generalize from, the results indicate that forecasts of the levels of demand intensity based on the elasticlty function E3 and assuming demand to be proportional to the 0.4 power of the per capita GNP lagged by one year, yield results as 
TABLE IV.9

TIME SERIES FORECASTS FOR IRELAND

(LAGGED GNP EXPONENT $=0.7$ )

\begin{tabular}{|c|c|c|c|c|c|c|c|}
\hline \multicolumn{2}{|r|}{ ACTUAL } & \multicolumn{6}{|c|}{ FORECASTS } \\
\hline YEAR & $D(t)$ & $D 1(t)$ & ERROR $1(\%)$ & $\mathrm{D} 2(t)$ & ERROR 2(\%) & $\mathrm{D} 3(\mathrm{t})$ & ERROR $3(\%)$ \\
\hline $\begin{array}{l}1968 \\
1969 \\
1970 \\
1971 \\
1972 \\
1973 \\
1974 \\
1975\end{array}$ & $\begin{array}{l}820.10 \\
866.81 \\
912.56 \\
946.12 \\
958.90 \\
1031.5 \\
1034.3 \\
1031.5\end{array}$ & $\begin{array}{l}829.63 \\
874.10 \\
939.91 \\
969.71 \\
996.85 \\
994.53 \\
1033.2 \\
1050.6\end{array}$ & $\begin{array}{l}00.01 \\
00.84 \\
03.00 \\
02.49 \\
03.96 \\
-3.58 \\
-0.11 \\
01.85\end{array}$ & $\begin{array}{l}827.83 \\
869.65 \\
932.97 \\
962.69 \\
988.61 \\
984.63 \\
1022.3 \\
1039.5\end{array}$ & $\begin{array}{l}00.01 \\
00.33 \\
02.24 \\
01.75 \\
03.10 \\
-4.54 \\
-1.17 \\
00.77\end{array}$ & $\begin{array}{l}828.20 \\
871.10 \\
936.43 \\
965.98 \\
994.93 \\
983.40 \\
1023.5 \\
1038.8\end{array}$ & $\begin{array}{l}00.01 \\
00.50 \\
02.62 \\
02.10 \\
03.76 \\
-4.66 \\
-1.05 \\
00.71\end{array}$ \\
\hline \multicolumn{8}{|c|}{ (LAGGED GNP EXPONENT $=: 0.4$ ) } \\
\hline $\begin{array}{l}1968 \\
1969 \\
1970 \\
1971 \\
1972 \\
1973 \\
1974 \\
1975\end{array}$ & $\begin{array}{l}820.10 \\
866.81 \\
912.56 \\
946.12 \\
958.90 \\
1031.5 \\
1034.3 \\
1031.5\end{array}$ & $\begin{array}{l}827.36 \\
860.16 \\
904.24 \\
919.78 \\
941.20 \\
930.65 \\
956.37 \\
962.40\end{array}$ & $\begin{array}{l}00.01 \\
-0.77 \\
-0.91 \\
-2.78 \\
-1.85 \\
-9.77 \\
-7.54 \\
-6.70\end{array}$ & $\begin{array}{l}825.56 \\
855.78 \\
897.57 \\
913.13 \\
933.43 \\
921.38 \\
946.28 \\
952.24\end{array}$ & $\begin{array}{l}00.01 \\
-1.27 \\
-1.64 \\
-3.49 \\
-2.66 \\
-10.7 \\
-8.51 \\
-7.69\end{array}$ & $\begin{array}{l}825.93 \\
857.21 \\
900.90 \\
916.25 \\
939.40 \\
920.23 \\
947.44 \\
951.59\end{array}$ & $\begin{array}{l}00.01 \\
-1.11 \\
-1.28 \\
-3.16 \\
-2.03 \\
-10.8 \\
-8.40 \\
-7.75\end{array}$ \\
\hline
\end{tabular}


TABLE IV.10

TIME SERIES FORECASTS FOR JAPAN

(LAGGED GNP EXPONENT $=0.7$ )

\begin{tabular}{|c|c|c|c|c|c|c|c|}
\hline \multicolumn{2}{|r|}{ ACTUAL } & \multicolumn{6}{|c|}{ FORECASTS } \\
\hline YEAR & $D(t)$ & $\mathrm{D} 1(\mathrm{t})$ & ERROR 1(\%) & $\mathrm{D} 2(\mathrm{t})$ & ERROR 2(\%) & D3 $(t)$ & ERROR $3(\%)$ \\
\hline $\begin{array}{l}1968 \\
1969 \\
1970 \\
1971 \\
1972 \\
1973 \\
1974 \\
1975\end{array}$ & $\begin{array}{l}409.79 \\
421.30 \\
432.92 \\
441.89 \\
436.88 \\
444.44 \\
444.85 \\
475.04\end{array}$ & $\begin{array}{l}426.43 \\
464.87 \\
511.98 \\
550.16 \\
598.21 \\
624.75 \\
664.35 \\
711.41\end{array}$ & $\begin{array}{l}00.04 \\
10.34 \\
18.26 \\
24.50 \\
36.93 \\
40.57 \\
49.34 \\
49.76\end{array}$ & $\begin{array}{l}426.14 \\
465.20 \\
515.20 \\
553.27 \\
583.75 \\
599.82 \\
615.92 \\
660.55\end{array}$ & $\begin{array}{l}00.04 \\
10.42 \\
19.01 \\
25.20 \\
33.62 \\
34.96 \\
38.46 \\
39.05\end{array}$ & $\begin{array}{l}426.94 \\
467.39 \\
520.49 \\
558.70 \\
577.91 \\
586.54 \\
585.12 \\
630.39\end{array}$ & $\begin{array}{l}00.04 \\
10.94 \\
20.23 \\
26.43 \\
32.28 \\
31.97 \\
31.53 \\
32.70\end{array}$ \\
\hline \multicolumn{8}{|c|}{ (LAGGED GNP EXPONENT $=0.4$ ) } \\
\hline $\begin{array}{l}1968 \\
1969 \\
1970 \\
1971 \\
1972 \\
1973 \\
1974 \\
1975\end{array}$ & $\begin{array}{l}409.79 \\
421.30 \\
432.92 \\
441.89 \\
436.88 \\
444.44 \\
444.85 \\
475.04\end{array}$ & $\begin{array}{l}416.82 \\
438.97 \\
464.22 \\
483.78 \\
512.40 \\
527.02 \\
548.44 \\
573.36\end{array}$ & $\begin{array}{l}00.02 \\
04.19 \\
07.23 \\
09.48 \\
17.29 \\
18.58 \\
23.29 \\
20.70\end{array}$ & $\begin{array}{l}416.53 \\
439.29 \\
467.14 \\
486.51 \\
500.02 \\
505.98 \\
508.47 \\
532.37\end{array}$ & $\begin{array}{l}00.02 \\
04.27 \\
07.90 \\
10.10 \\
14.45 \\
13.85 \\
14.30 \\
12.07\end{array}$ & $\begin{array}{l}417.32 \\
441.35 \\
471.94 \\
491.29 \\
495.02 \\
494.77 \\
483.04 \\
508.07\end{array}$ & $\begin{array}{l}00.02 \\
04.76 \\
09.01 \\
11.18 \\
13.31 \\
11.33 \\
08.58 \\
06.95\end{array}$ \\
\hline
\end{tabular}


close as within. 018 of the actual values and with a maximum absolute deviation of less than 13.58 .

For the purpose of forecasting demand for motor gasoline, which is a complex variable governed by interacting social, cultural, and economic factors, the above accuracy is quite satisfactory.

\section{Forecasts Based on The cross Section Results}

The per capita demand function estimated via cross section analysis was utilized for the retrospective prediction of gasoline demand levels in France, Ireland and Japan.

In calculating the forecasted values for each of the three control countries, the following procedure was followed:

1. An exponential demand function of the following form was assumed:

$D C(t)=A \quad P \cdot F$.

2. The 1965 values of $D C(t)$ and $P . F$. were used to calculate A.

3. The forecast of $D C(t)$ for each succeeding year was found by substituting the corresponding value of P.F. Into the estimated demand function.

Tables IV.II through IV.I3 display the forecasting results with the resulting percentage errors. The tables 
show the following:

1. The forecasts for France had percentage errors in the range -21.38 to +15.28 with a smallest value of +1.98. Seven of the forecasts were positively deviated from the actual values.

2. The error range was smaller for Ireland. The predicted values lied within -8.68 to +11.98 of the actual values.

3. The highest prediction errors were associated with Japan where the forecasted values lied within -298 to +22.38 .

It can be seen from the valldation results that the forecasts which were based on the cross section formulae had bigger associated percentage errors than those based on the time series findings.

\section{SUMMARY OF THE REGRESSION ANALYSIS}

The findings of chapters III and IV are summed up in the following paragraphs:

1. The investigation started out with time series analysis of four hypothesized models. The first model: a linear function; was found statistically more significant and thus chosen for further analysis. 
TABLE IV.11

CROSS-SECTION FORECASTS FOR FRANCE

\begin{tabular}{llll}
\hline YEAR & $D$ (ACTUAL) & D (FORECAST) & ERROR (\%) \\
\hline & & & \\
1966 & 1.069 & 1.090 & 001.9 \\
1967 & 1.147 & 1.169 & 001.9 \\
1968 & 1.232 & 1.279 & 003.7 \\
1969 & 1.303 & 1.472 & 011.5 \\
1971 & 1.392 & 1.642 & 015.2 \\
1972 & 1.496 & 1.747 & 014.4 \\
1973 & 1.616 & 1.821 & 011.3 \\
1974 & 1.741 & 1.536 & -13.3 \\
1975 & 1.669 & 1.428 & -16.9 \\
& 1.737 & 1.367 & -21.3 \\
\hline
\end{tabular}

TABLE IV. 12

CROSS-SECTION FORECASTS FOR IRELAND

\begin{tabular}{llll}
\hline YEAR & D (ACTUAL) & D (FORECAST) & ERROR (\%) \\
\hline & & & \\
1966 & 0.864 & 0.851 & -1.5 \\
1967 & 0.936 & 0.921 & -1.6 \\
1968 & 1.019 & 1.050 & 03.0 \\
1969 & 1.123 & 1.193 & 05.9 \\
1970 & 1.203 & 1.319 & 08.8 \\
1971 & 1.287 & 1.352 & 04.8 \\
1972 & 1.355 & 1.538 & 11.9 \\
1973 & 1.501 & 1.382 & -8.6 \\
1974 & 1.490 & 1.457 & -2.3 \\
1975 & 1.465 & 1.373 & -6.7 \\
\hline
\end{tabular}


TABLE IV.13

CROSS-SECTION FORECASTS FOR JAPAN

\begin{tabular}{llll}
\hline YEAR & D (ACTUAL) & D (FORECAST) & ERROR (\%) \\
\hline & & & \\
1956 & 0.505 & 0.518 & 002.5 \\
1967 & 0.617 & 0.614 & -00.5 \\
1968 & 0.648 & 0.755 & 014.2 \\
1969 & 0.737 & 0.893 & 017.5 \\
1970 & 0.828 & 1.066 & 022.3 \\
1971 & 0.888 & 1.123 & 020.0 \\
1972 & 0.942 & 1.022 & 007.8 \\
1973 & 1.038 & 0.985 & -05.1 \\
1974 & 1.014 & 0.719 & -29.0 \\
1975 & 1.094 & 0.800 & -26.8 \\
\hline
\end{tabular}


2. Strong mutual correlations among the explanatory variables were detected through principal components analysis and consequently, five versions of the chosen model were formed by deleting various variables and were analyzed to check the sensitivity of the model to multicollinearity.

3. The results indicated reasonable elasticity values of demand intensity with respect to current prices and per capita GNP lagged with one year. It was concluded that current prices and per capita GNP lagged by one year were good Indicators of the determinants of the elasticity of demand.

4. The ratio of current price to current GNP per capita was introduced. It was labelled as the price factor and denoted P.F. The elasticity values for the various countries displayed rational behavior when averaged over ranges of $P . F$.

5. The time series analysis resulted in the following estimated functions for the elasticity of demand intensity with respect to current prices:

$$
\begin{aligned}
& E 1=-0.74+\left(24.37 / P \cdot F_{0}\right) \\
& E 2=1.003-0.3151 \mathrm{n} \cdot\left(P \cdot F_{.}\right) \\
& E 3=P \cdot F \cdot /(-153.26-0.719 \text { P.F.) }
\end{aligned}
$$


for P.F. ranging from 15 to $190 . E(D(t), P(t))$ was assumed equal to zero for values of P.F. less than 15 .

6. The intensity of demand for motor gasoline was found, through time series analysis, proportional to the lagged per capita GNP, raised to the power of $0.7 \pm 0.3$.

7. Cross sectional analysis of the annual data for the various countries revealed sound economic behavior of the per capita demand for motor gasoline, $D C(t)$, versus the price factor P.F.

8. An exponential demand function in P.F. was estimated via the cross section analysis with an

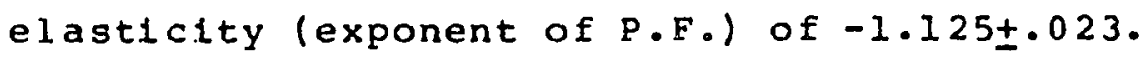

9. Using the time series findings for retrospective forecasting of various demand levels in France, Ireland, and Japan yielded better results than the cross sectionally estimated demand function.

10. The time series elasticity function E3 together with an 0.4 exponent of $G(t-1)$ yielded the best over all results. with absolute forecast errors below 13.58 . 


\section{CH APTE R $\mathbf{v}$.}

\section{POLICY IMPLICATIONS OF THE RESEARCH FINDINGS}

The policy implications of the present research and 1 ts applicability as a decision making tool are demonstrated in this chapter via two simulation models.

The first is an exploratory simulation which incorporates the findings of the time series analysis together with an extrapolation of the historical growth trends of the per captta GNP and the gasoline prices in the U.S. to predict the levels of future demand for motor gasoline t111 the year 1990. Several scenarios were built around the base run degcribed in the preceding paragraph by making various assumptions about the growth rates.

The chapter is concluded with a normative simulation where, starting with the demand reductions desired in President Carter's energy program and assuming price to be the only policy mechanism to control demand, a price profile Is heuristically found which would achieve the target levels.

\section{THE EXPLORATORY RUN}

Figures $V .1$ and $V .2$ depict the historlcal trends in the per capita GNP, in constant 1970 dollars per person, and the price factor P.F.. respectively, for the years 1965 
FIGURE V.1

HISTORICAL TREND OF REAL GNP/CAP.

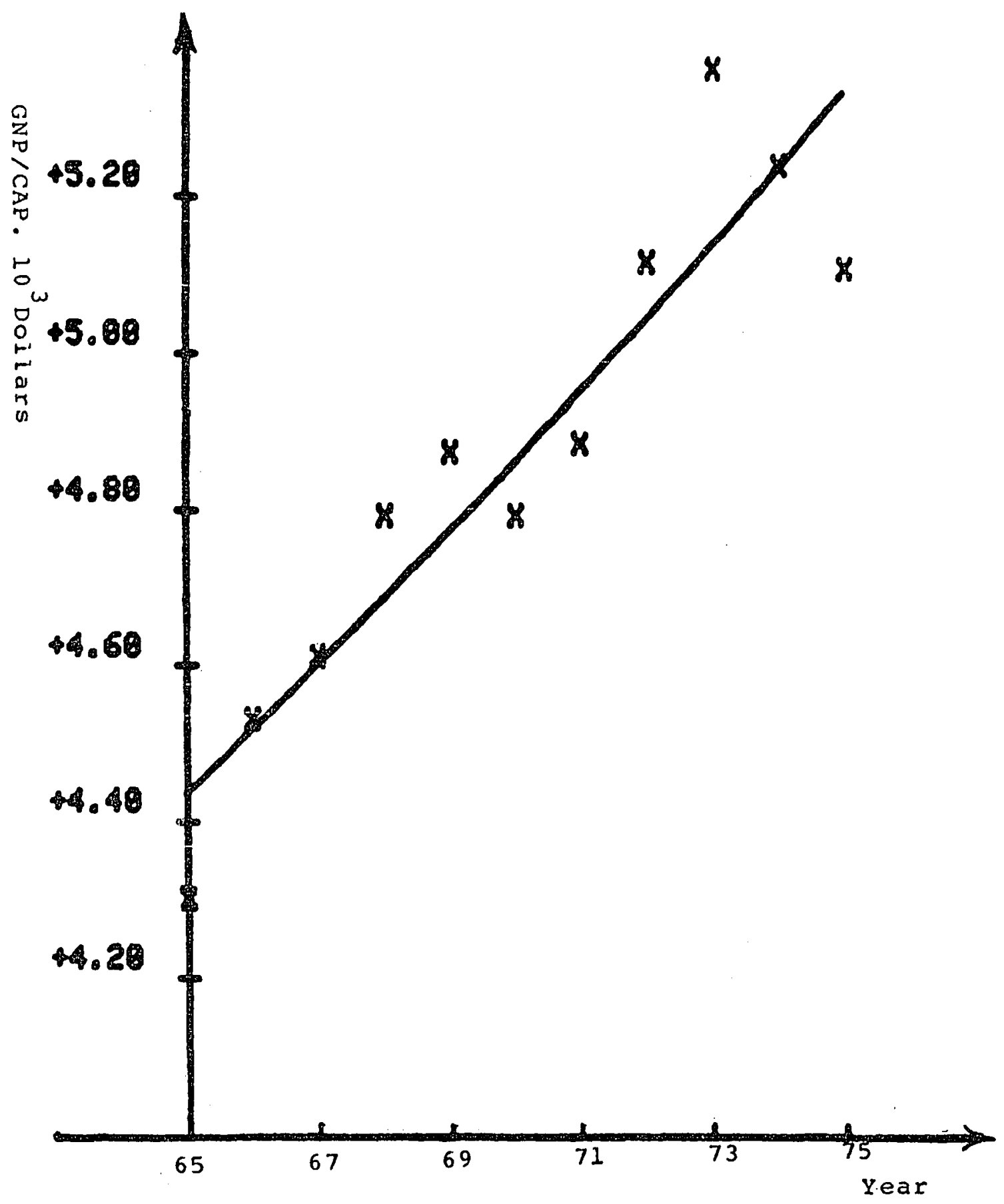


TABLE V.I

REGRESSION RESULTS OF GNP/CAP. TREND.

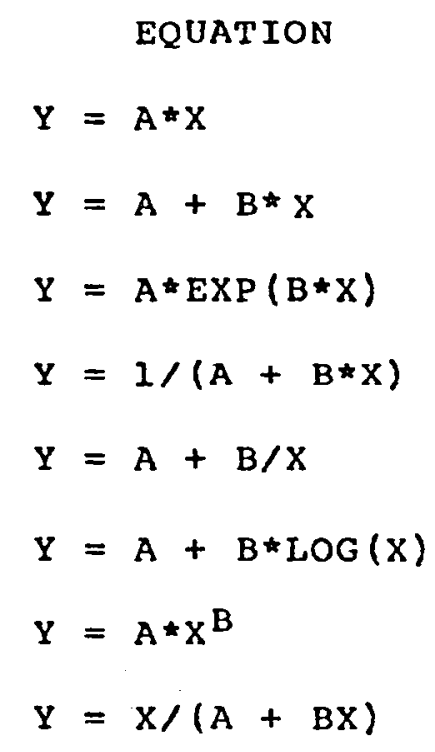

A

0.72070

4.42955

4.43624

0.22514

$\mathrm{CAN}^{\top} \mathrm{T}$ FIT

$\mathrm{CAN}^{\circ} \mathrm{T}$ FIT

$\mathrm{CAN}^{-} \mathrm{T}$ FIT

$\mathrm{CAN}^{\circ} \mathrm{T}$ FIT
B

$$
0.00000
$$

0.08791

0.01824

$-0.00379$

R-SQUARE

MAX DEVIATION

INSIGNIF .

4.30000

0.21718

0.22365

0.24153 
TABLE V. 2

REGRESSION RESULTS OF PRICE FACTOR TREND

EQUATION

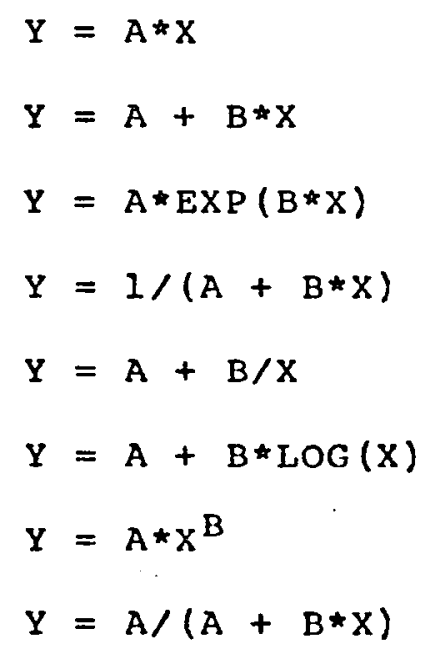

A

1.16139

9.18250

9.16875

0.10921

CAN'T FIT

$\mathrm{CAN}^{\circ} \mathrm{T}$ FIT

CAN $^{-} T$ FIT

$\mathrm{CAN}^{\circ} \mathrm{T}$ FIT

\section{B}

$$
0.00000
$$

$-0.15039$

$-0.01775$

0.00211

R-SQUARE

INSIGNIF .

0.33879

0.35582

0.36917
MAX DEVIATION

$$
\begin{aligned}
& 9.84000 \\
& 1.14941 \\
& 1.15036 \\
& 1.15580
\end{aligned}
$$


FIGURE V.2

HISTORICAL TREND OF THE PRICE FACTOR

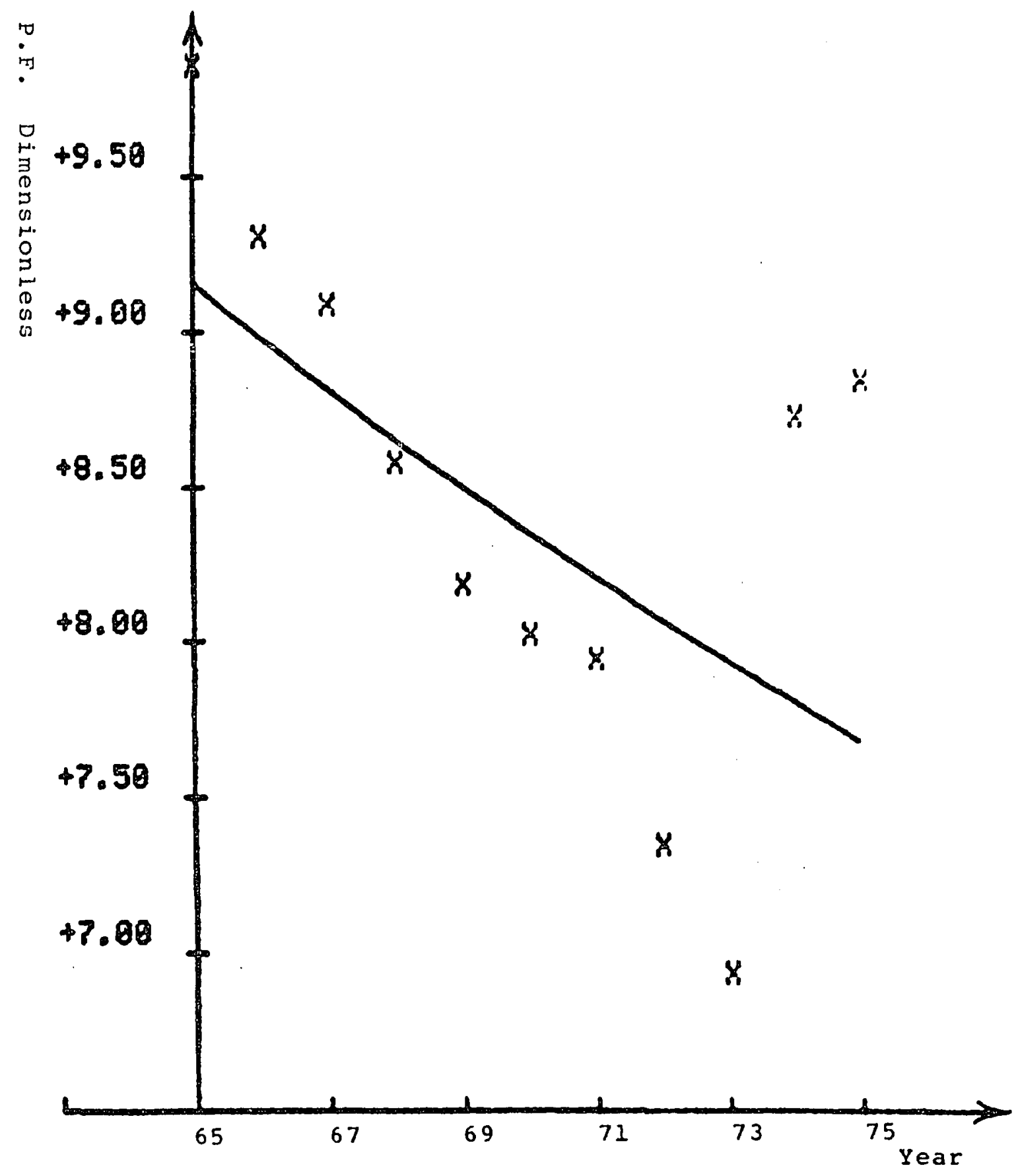


through 1975. Tables V.1 and V.2 display the regression results of the two trends.

Table V.l indicates good fit of the historical data both to the linear and the exponential functions. The latter was chosen in order to facilitate comparison of the growth rates of the different variables.

Figure V.l Indicates an exponential trend with an annual growth rate of 1.8248 in real per capita GNP for the specified period, despite a slight decrease for the years 1974 and 1975 .

Figure V.2 displays a poor fit of the trend equation to the P.F. data. It is obvious from the figure that the historlcal changes would better fit two discontinous trends. The first of these is a decreasing trend between the years 1965 and 1973, while the second is an increasing trend starting 1973. Th1s discontinuity can be explained by the relative price Increase after 1973 coupled with the drop in the per capita GNP displayed in figure v.l.

Figure V.3 depicts the historical change in gasoline prices, In constant 1970 dollars. It shows that the price of motor gasoline has been decreasing in real terms till 1974.

The assumptions about future prices of motor gasoline were made exogenously, independently of the historical trend, for the following reasons:

1. The historical trend is not expected to prevail in 


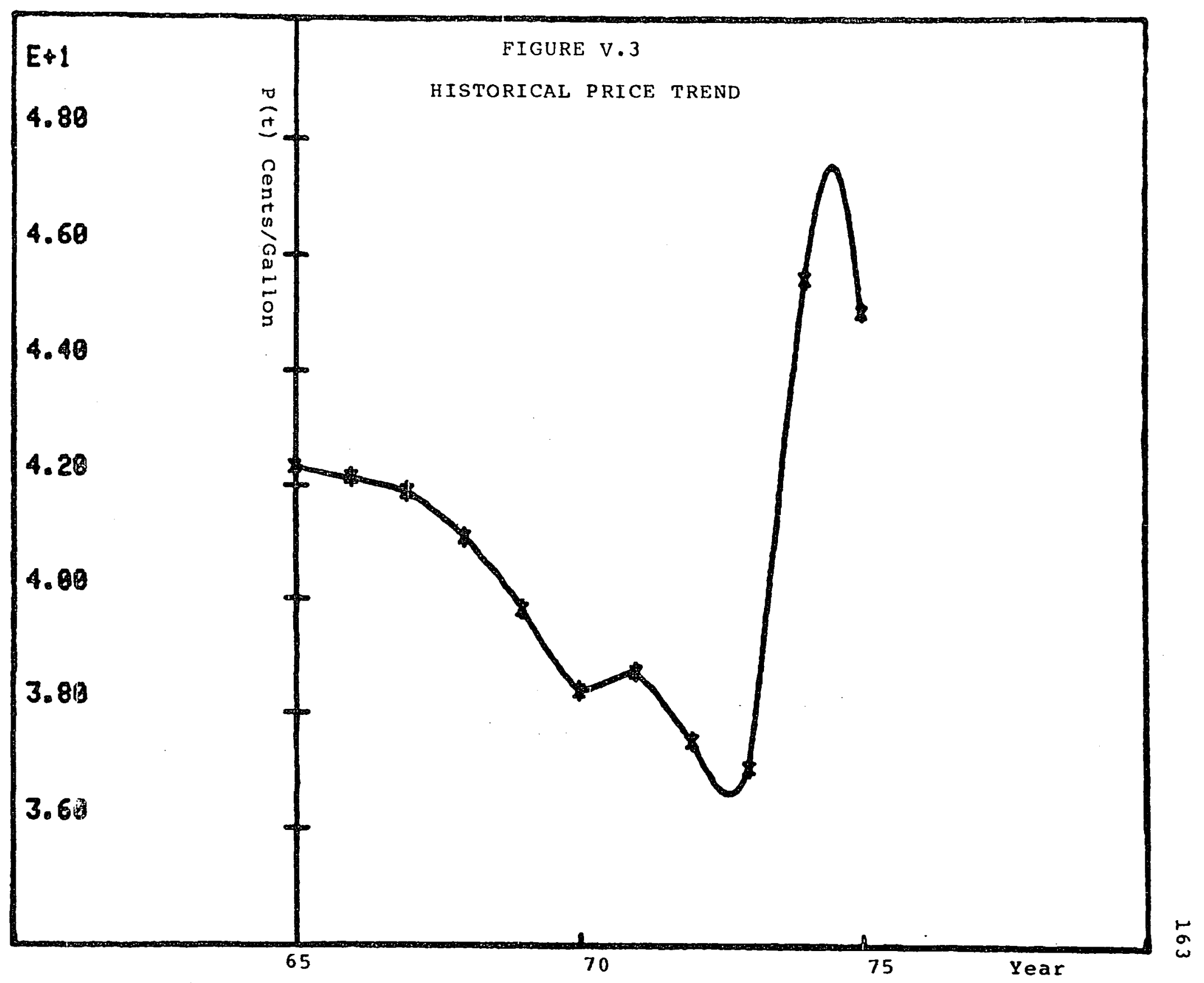




\section{the future.}

2. The trend of decreasing prices 18 of ittele interest to the questions addressed In this thes1s.

Based on the estimated trends, the following runs were made:

\section{Base Run}

In the base run, the following assumptions we re made:

1. GNP per capita will grow at 1 ts historical rate of 1.8248 annually during the forecast pertod.

2. During the same period, price will grow at an annual rate of 58 .

Starting with the 1975 values of $D(t), G(t)$ and $P(t)$, future demand of motor gasoline per GNP was generated by the following algorithm:

1. The historical demand intensity for motor gasoline was regressed against time ylelding the results displayed in table $V .3$ and depicted in figure V.4. The demand intensity was found increasing exponentially at about 28 per annum, between 1965 and 1975. This historical trend was extended into the future. 
H ISTORICAL GROWTH OF DEMAND INTENSITY

\begin{tabular}{|c|c|c|c|}
\hline CURVE TYPE & OF DETERMINATION & A & B \\
\hline 1. $E=A+B \cdot(P \cdot E \cdot)$ & .926 & 1291 & 28.209 \\
\hline 2. $E=A \cdot E X P \cdot(B \cdot(P \cdot F \cdot))$ & .8327 & 1304.5 & 0.013 \\
\hline $3 \cdot E=A \cdot(P \cdot F \cdot)^{B}$ & $\mathrm{CAN}^{-} \mathrm{T}$ FIT & & \\
\hline $4 \cdot E=A+(B / P \cdot F \cdot)$ & $\mathrm{CAN}^{\circ} \mathrm{T}$ FIT & & \\
\hline $5 \cdot E=1 /(A+B \cdot(P \cdot F \cdot))$ & .9289 & $7.73 E-04$ & $-1.49 E-05$ \\
\hline $6 \cdot E=R /(A+B \cdot(P \cdot F \cdot))$ & $\mathrm{CAN}^{\prime} \mathrm{T}$ FIT & & \\
\hline $7 \cdot E=A+B \cdot \log (P, F \cdot)$ & $\mathrm{CAN}^{\circ} \mathrm{T}$ FIT & & \\
\hline
\end{tabular}

STANDARD ERROR ESTIMATES

CURVE TYPE

1.
2.
3.
4.
5.
6.
7.
REG RESSION

18.9315
$1.357 \mathrm{E}-02$
0
0
$9.736 \mathrm{E}-06$
0
0

A

B

$\begin{array}{ll}12.8996 & 3.5777 \\ 1.0093 & 2.564 \mathrm{E}-03 \\ 0 & 0 \\ 0 & 0 \\ 6.63 \mathrm{E}-06 & 1.840 \mathrm{E}-06 \\ 0 & 0 \\ 0 & 0\end{array}$


FIGURE $V=4$

HISTORICAL TREND OF DEMAND INTENSITY

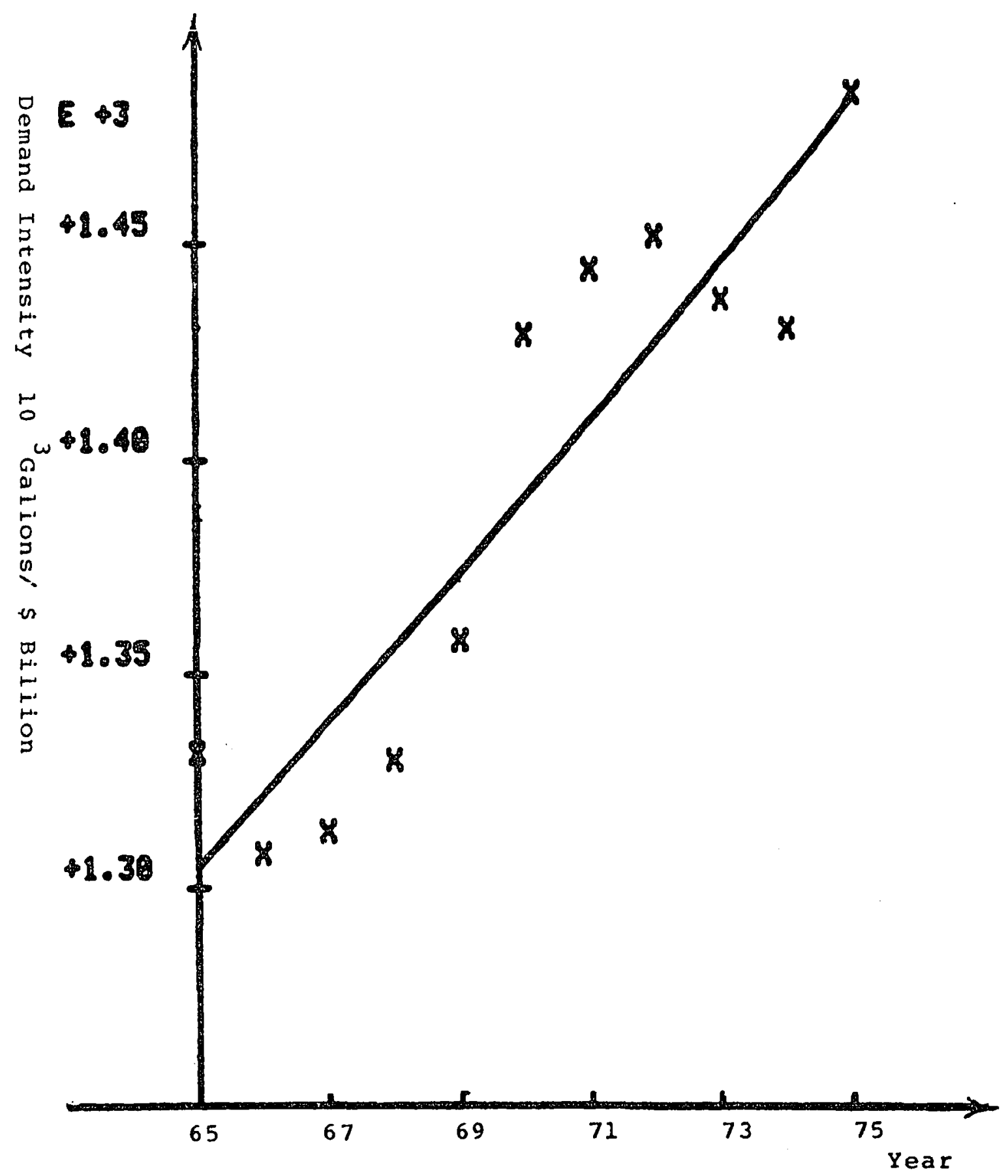


future prices and per caplta GNP were calculated.

3. $P(t)$ and $G(t)$ were used to calculate the price factor at year t; P.F. The elasticity function E3 $(t)$ was then calculated from the knowledge of P.F.

4. From the definition of elastlcity, the following relations were derived:

$E(t)=(D(t+1)-D(t)) /(P(t+1)-P(t))$

Therefore

$D(t+1)=(((P(t+1)-P(t)) / P(t)) \cdot E(t)+1) \cdot D(t) \quad[5 \cdot 2]$

5. Time series analysis in chapter II showed that the demand Intensity for motor gasoline was also proportional to the lagged per caplta GNP ralsed to the 0.4 power.

6. Using steps 4 and 5 above, the following formula was derived to generate the level of the demand intensity in year $t+1$ :

$D(t+1)=(((P(t+1)-P(t)) / P(t)) \cdot E(t)+1)$ $(G(t-1) / G(t-2))^{0.4} D(t)$

Table V.4 displays the results of the base run.

The table reveals that under the assumptions of the base run, future demand would follow its historical trend 
TABLE V. 4

POLICY SIMULATION: BASE RUN

$\begin{array}{lcrlll}\text { YEAR } & P(t) & \text { P.F. } & \text { DT }(t) & D(t) & R \text { R }(t) \\ 1976 & 47.27 & 9.10 & 1514.18 & 1514.18 & 0.00 \\ 1977 & 49.63 & 9.38 & 1545.55 & 1545.55 & 0.00 \\ 1978 & 52.12 & 9.67 & 1577.56 & 1577.56 & 0.00 \\ 1979 & 54.72 & 9.97 & 1610.23 & 1610.23 & 0.00 \\ 1980 & 57.46 & 10.28 & 1643.58 & 1643.58 & 0.00 \\ 1981 & 60.33 & 10.60 & 1677.62 & 1677.62 & 0.00 \\ 1982 & 63.35 & 10.93 & 1712.37 & 1712.37 & 0.00 \\ 1983 & 66.52 & 11.27 & 1747.83 & 1747.83 & 0.00 \\ 1984 & 69.34 & 11.62 & 1784.03 & 1784.03 & 0.00 \\ 1985 & 73.33 & 11.98 & 1820.98 & 1820.98 & 0.00 \\ 1986 & 77.00 & 12.35 & 1858.70 & 1858.70 & 0.00 \\ 1987 & 80.85 & 12.74 & 1897.20 & 1897.20 & 0.00 \\ 1988 & 84.89 & 13.13 & 1936.49 & 1936.49 & 0.00 \\ 1989 & 89.14 & 13.54 & 1976.60 & 1976.60 & 0.00 \\ 1990 & 93.59 & 13.96 & 2017.54 & 2017.54 & 0.00\end{array}$

TABLE V. 5

POLICY SIMULATION: HIGH PRICE GROWTH RATE

$\begin{array}{lrrrrr}1976 & 49.52 & 9.53 & 1514.18 & 1514.18 & 0.00 \\ 1977 & 54.47 & 10.30 & 1545.55 & 1545.55 & 0.00 \\ 1978 & 59.92 & 11.12 & 1577.56 & 1577.56 & 0.00 \\ 1979 & 65.91 & 12.01 & 1610.23 & 1610.23 & 0.00 \\ 1980 & 72.51 & 12.98 & 1643.58 & 1643.58 & 0.00 \\ 1981 & 79.76 & 14.02 & 1677.62 & 1677.62 & 0.00 \\ 1982 & 87.73 & 15.14 & 1712.37 & 1712.37 & 0.00 \\ 1983 & 96.50 & 16.35 & 1747.83 & 1709.00 & -2.22 \\ 1984 & 106.15 & 17.66 & 1784.03 & 1704.45 & -4.46 \\ 1985 & 116.77 & 19.08 & 1820.98 & 1698.66 & -6.72 \\ 1986 & 128.45 & 20.61 & 1858.70 & 1691.55 & -8.99 \\ 1987 & 141.29 & 22.26 & 1897.20 & 1683.04 & -11.29 \\ 1988 & 155.42 & 24.04 & 1936.49 & 1673.07 & -13.60 \\ 1989 & 170.96 & 25.97 & 1976.60 & 1661.57 & -15.94 \\ 1990 & 188.06 & 28.05 & 2017.54 & 1648.45 & -18.29\end{array}$

$D T=T R E N D$ DEMAND RED $=$ DEMAND REDUCTION $(z)$ 
with no effect due to price Increases.

The base run Indicates that, with the price growing at about three times the rate of the GNP per capita, demand will remain unaffected till the year 1990 . A faster growth rate of the price of gasoline was therefore examined in the second run.

\section{High Price Growth Rate.}

In this run, price was assumed to grow at 108 per annum while per capita GNP was growing at 1 ts historical rate. This makes price grow about six times faster than the GNP per capita. Table V.5 displays the forecasted values of this case.

It can be seen that under the assumptions of this run, demand intensity starts dropping below 1ts historical trend by 1983 where the drop 1s 28 . The reduction in demand per GNP Increases gradually to reach 18.38 BY 1990.

The assumption of an expanding economy was then examined in a third run where the GNP per capita was allowed to grow faster than 1ts historical trend.

\section{Expanding Economy.}

In this third run, the GNP per caplta was assumed to grow at 1.5 times 1 ts historical rate or at a rate of 2.748 per annum. The price growth rate was maintained at 108 annually. The run ylelded the results displayed in table V.6.

Table V.6 shows that under the assumptions of the 
TABLE V. 6

POLICY SIMULATION: EXPANDING ECONOMY

$\begin{array}{lrrrrr}\text { Year } & P(t) & \text { P.F. }(t) & \text { DT }(t) & \text { D }(t) & \text { RED }(t) \\ & & & & & \\ 1976 . & 49.52 & 9.45 & 1514.18 & 1514.18 & 0.00 \\ 1977 . & 54.47 & 10.12 & 1545.55 & 1545.55 & 0.00 \\ 1978 . & 59.92 & 10.83 & 1577.56 & 1577.56 & 0.00 \\ 1979 . & 65.91 & 11.59 & 1610.23 & 1610.23 & 0.00 \\ 1980 . & 72.51 & 12.41 & 1643.58 & 1643.58 & 0.00 \\ 1981 . & 79.76 & 13.29 & 1677.62 & 1677.62 & 0.00 \\ 1982 . & 87.73 & 14.22 & 1712.37 & 1712.37 & 0.00 \\ 1983 . & 96.50 & 15.22 & 1747.83 & 1747.83 & 0.00 \\ 1984 . & 106.15 & 16.30 & 1784.03 & 1750.56 & -1.88 \\ 1985 . & 116.77 & 17.45 & 1820.98 & 1752.21 & -3.78 \\ 1986 . & 128.45 & 18.68 & 1858.70 & 1752.73 & -5.70 \\ 1987 . & 141.29 & 19.99 & 1897.20 & 1752.03 & -7.65 \\ 1988 . & 155.42 & 21.40 & 1936.49 & 1750.06 & -9.63 \\ 1989 . & 170.96 & 22.91 & 1976.60 & 1746.74 & -11.63 \\ 1990 . & 188.06 & 24.53 & 2017.54 & 1741.99 & -13.66\end{array}$


present run, äemand would start falling at 1.88 in 1984 with the drop increasing gradually to reach 13.66 of by the year 1990.

It is clear from the above 11 lustrations that any sets of assumptions can be introduced to the main model thus providing useful insights into the implications of various economic policles. In this light, the section of president Carter's energy program pertaining to the transportation sector was examined.

\section{PRESIDENT CARTER'S ENERGY PROGRAM}

THE TRANSPORTAT ION SECTOR

As stated In the publication by the Executive office of the President (1977, p. 35), the policies of the President's program pertalning to transportation may be summarized in the following points:

1. A national goal to reduce gasoline consumption by 108 by the year 1985.

2. One provision for achieving this goal is through a graduated excise tax on new automobiles with low fuel efficiency together with graduated rebates for new cars with "mileage better than the standard".

3. A second provision is to establish "annual targets for gasoline consumption, backed by a standby tax on gasolinen. 
4. The gasoline tax is to go into effect starting 1979. In any one year, a tax of 5 cents per gallon is imposed for each 18 excess of consumption over the target for the preceding year. The same tax would be removed if a target consumption is met.

5. A maximum tax of 5 cents can be Imposed in any one year, and the maximum over all tax cannot exceed 50 cents.

Since the expert opinions cited on page 13 of this thesis cast doubts on the feasiblitty of improved specific Euel consumption per car earlier than 1985, and since the present investigation pertains to the consumers behavior in regards to gasoline consumption, the policy simulation was designed in such a way as to address the following question:

If the President's consumption goals of motor gasoline were to be achieved through the gasoline tax alone, what would the neccessary price proflle be 1111 the year $1985 ?$

The policy simulation run was thus conducted under the following assumptions:

1. The GNP per capita and the demand per GNP will grow at their historic rate throughout the forecast per1od.

2. The price of gasoline will remain constant till 
1978, then 1t will start increasing at a constant rate to achieve the consumption goal. Price will remain constant through 1990 at the level attained In 1985 .

The simulation was done heurlstically by trying different rates of price 1ncrease. A 228 annual rate of growth of the price of motor gasoline was found to achieve the prescribed goal. Table V.7 displays the results.

It may be observed that the annual price increases starting 1978, well exceeded the 5 cents per galion limit called for in the President's program. One may also observe the time lag bulit into the system which is reflected by the fact that reduction in gasoline consumption would start in 1983 with the gradual "tax" of 228 introduced in 1979. A drastic sudden Increase of gasoline price would have to be effected if the consumers conservation efforts were to start Immediately. With an expanding economy, the Increases would obviously have to be more drastic. 
TABLE V.7

POLICY SIMULATION: NORMATIVE RUN

\begin{tabular}{llrllr} 
YEAR & P(t) & P.F. & \multicolumn{1}{l}{$D T(t)$} & $D(t)$ & RED $(t)$ \\
1976 & 45.02 & 8.59 & 1514.18 & 1514.18 & 0.00 \\
1977 & 45.02 & 8.36 & 1545.55 & 1545.55 & 0.00 \\
1978 & 45.02 & 8.14 & 1577.56 & 1577.56 & 0.00 \\
1979 & 54.92 & 9.66 & 1610.23 & 1610.23 & 0.00 \\
1980 & 67.01 & 11.47 & 1643.58 & 1643.58 & 0.00 \\
1981 & 81.75 & 13.62 & 1677.62 & 1677.62 & 0.00 \\
1982 & 99.73 & 16.17 & 1712.37 & 1712.37 & 0.00 \\
1983 & 121.68 & 19.20 & 1747.83 & 1693.74 & -3.09 \\
1984 & 148.44 & 22.79 & 1784.03 & 1668.98 & -6.45 \\
1985 & 181.10 & 27.06 & 1820.98 & 1637.35 & -10.08 \\
1986 & 181.10 & 26.33 & 1858.70 & 1655.25 & -10.95 \\
1987 & 181.10 & 25.63 & 1897.20 & 1673.35 & -11.80 \\
1998 & 181.10 & 24.94 & 1936.49 & 1691.64 & -12.64 \\
1989 & 181.10 & 24.27 & 1976.60 & 1710.13 & -13.48 \\
1990 & 181.10 & 23.62 & 2017.54 & 1728.82 & -14.31
\end{tabular}




\section{CHAPTER VI}

SUMMARY, CONCLUSIONS AND RECOMMENDATIONS

In the fol lowing sections, the methodology followed in this research 18 summarized, together with the findings and recommendations for future extenglons of the work.

\section{SUMMARY}

This research investigates the size and determinants of the elastlcity of demand for motor gasoline.

As has been mentioned in chapter $I$, distinguished researchers have noted the need for the current research. They strongly emphaslze that the mere indications of a consumers" demand pattern for energy products, which approaches rational econontc behavior or which lends itself to economic and behavioral theory, would be a contribution to the field of energy modeling.

In this light, the findings of the current research are presented.

Throughout this investigation, basic economic theory and econometric techniques were combined with subjective judgements, in order to ensure the reasonableness of the findings.

In order to account for the differences in GNP levels among countries, demand Intensity, defined as the total 
denand of motor gasoline in any one year divided by the GNP for that year, was used Instead of pure demand. Data of the twenty member organization for Economic Cooperation and Development (OECD) were utilized in the analysis. Two of the countries, Greece and Turkey, had incomplete data and were therefore excluded from the analysis.

In order to examine the accuracy of the research findings, three of the countries, France, Ireland and Japan: were kept out of the analysis.

Analysis of the time series data of the remalning fifteen countries revealed an elasticity of demand per GNP for motor gasoline with respert to current prices and the per capita GNP lagged by one year.

The ratio of current price to current GNP per capita was, to the best of my knowledge, introduced in this research and proposed as an explanatory parameter for the variability across countries of the elastictty of demand Intensity with respect to the different parameters. Because it measures an "effective" price, this ratio was called the price factor and was labelled P.F.

It turned out that P.F. established the basls for Inter-country comparisons of time series results.

The analysis resulted in the following three functional relationshipg between the elasticity of demand intensity for motor gasoline and the price factor P.F. : 
$\operatorname{El}\left(P \cdot F_{.}\right)=-0.74+\left(24.37 / P \cdot F_{.}\right)$

$[6.1]$

$E 2(P \cdot F)=.1.003-0.315$ ln. (P.F.)

E $3\left(P \cdot F_{.}\right)=P \cdot F \cdot /(-153.26-0.719$ P.F. $)$

Demand intens1ty was found elastic with respect to the GNP per capita, lagged by one year: The elasticity coeffictent fell in the range of $0.7+0.3$.

Based on the findings of the time series analysis, it was hypothesized that the ratio P.F. Itself might provide an efficlent explanatory variable for the demand behavior in various countries. Consequently, cross section data of the f1fteen OECD countries, for the years 1965 through 1975 , were further analyzed.

Cross section analysis revealed that the per capita demand, rather than the demand per GNP, displayed rational economic demand behavior as a function of P.F. An elasticity of $-1.125+0.023$ was estimated for the demand per capita with respect to P.F.

The research findings were validated and the estimated formulae verified by retrogressively forecasting the annual demand levels in France, Ireland and Japan, for the period 1965-1975. Both time series and cross sectional findings were utilized.

The best retrospective forecasts resulted from ut1lizing formula 6.3 together with an elasticity coefficient of 0.4 with respect to the lagged per capita 
GNP. The maximum forecast errors were below 13.58 .

The Investigation was concluded by a policy stinulation run for the U.S. A price profile unt1l the year 1990 was generated which would achleve the conservation goals Indicated in Prestdent Carter's energy program. The policy run ind fcated that the taxes that would be neccessary to achieve the consumption goals are much higher than the 5 cents per galion annual celling proposed in the President's program.

Under the assumptions of the various models described in chapter III the conclusions given in the next section we re drawn.

\section{CONCLUSIONS}

1. The time series demand for motor gasoline per unit of GNP shows distinct elasticity with respect to prices and GNP per capita for various countries.

2. The "Price Factor" P.F., defined as the price of motor gasoline in cents per gallon to the per capita GNP in thousand dollars, shows a distinct relationship to the different elasticities. The price elasticity of demand averaged over countries, Is a decreasing function of the price factor over a range of P.F. values extending from 15 to 190. Below P.F. equals 15, the elasticity is negligibly small and 18 assumed zero. P.F. Is an Important 
explanatory parameter for the demand elasticlties. Wthout the introduction of P.F., the elasticity values appear to vary irregularly over countries.

3. The demand intensity was found elastic with respect to per capita GNP with a one year time lag. The estimated elasticity coefficient lied in the range of $0.7+0.3$

4. The elagticlty function given by equation 6.1 together with a demand elasticity of 0.4 with respect to the laggad GNP per capita, generate acceptable forecasts for demand levels in France, Ireland and Japan for the period 1965 to 1975. some of the forecasted values came as close as within less than one per cent of the artual, while the maxtmum error lied below 13.58 .

5. Assuming that the demand behavior derived from the analysls will apply to the U.S. For the years 19751990, it appears that the size of the gasoline tax schedule proposed in Prestdent Cãxter's energy program w11l be too small to achieve the desired consumption goals.

\section{Recommendations For Future Research}

It is my opinion that the following recommendations would enhance and extend the research investigated in this 
thes 1s.

1. As time elapses, longer time series would ba avallable to work with which would increase the precision of the parameter estimates.

2. I guggest that the inciusion of more developing countries at varying stages of economic development might reveal a functional dependence of the demand elasticity on the stage of development. It is felt that the behavior might show a logistic variation with the stage of development. It is suspected that detalled data will be lacking for most developing countries. Data problems are seen as the major obgtacle to the suggested investigation.

3. The current work may also be further generalized in several steps. First extending the saine Investigation to other energy sectors. Second, by viewing the whole energy sector in a macroeconomic context of the whole economy. Then, in a still more general context, behavioral and cultural considerations may be incorporated in a holistic complex.

4. Some of the possible behavioral and cultural considerations could be:

a. The difference in life styles among different countries, reflected in the varying degrees of 
urbanlzation, scatter versus clustering of cities, hablts of energy consumption, etc...

b. In the transportation sector, the significance of the private car to Americans and the possibility that it symbolizes personal freedom and privacy could make the cutoff threshold of (P.F.) higher than that suggested in this research. On the other hand, the materialistif outlook of the american consumer might compensate for the above effect. It would be interesting, yet definitely difficult to Investigate such influences.

c. The effects of the soclal awareness of eminent energy crises or the lack of conviction thereof would definttely tnfluence the consumers decision to consume energy. An investigation of the state of the publis opinion would provide an indication of likely trends in consumer behavior.

6. Using the cultrual, social and behavioral considerations mentioned above as inputs, in addition to the Investigated price responsiveness, to a holistic macroeconomic model that includes all energy sectors would, in our opinton, provide useful Insights into the prospect of attaining national goals with respect to energy consumption. 


\section{REFERENCES}

Aberg, C. J. 1968. The Demand for Paper and Paperboard in Western Europe 1950-1962. Stockholm Economic Studies, New Series $x$.

Adelman, M. A. 1975. "Population Growth and Oil Resources," Quarterly Journal of Economics.

Arrow, K. J. and M. Hoffenberg 1959. A Time Serles Analysis of Interindustiry Demands. North-Holland Publishing Company, Amsterdam, Netherlands.

Automobile Facts and Figures, various issues. A Publication (if the Motor Vehicles Manufacturers Association of the U.S. InC., Detrolt, Michigan \& Washington, D.C.

Beckman, M. Editor 1969. Economic Models, Estimation and Risk Programming: Essays in Honor of Gerhard Tintner. springer-Verlaq, New York.

Bridge, J. I. 1971. Applied Econometrics. North Holland Publishing Co.

Christ, C. F. 1962. Econometric Models and Methods. John wiley and Sons.

Denison, E. F. 1967. Why Growth Rates Differ: Postwar Experience in Nine Western Countries. The Brookings Institution, Washington, D. C.

Dorfman, R., P.A. Samuelson and R. M. Solow 1958. Linear Programming and Economis Analysis. MCGraw-llili, New York.

Draper, N. R. and H. Smith 1966. Applied Regression Analysis. John Wiley and Sons, N. Y.

Ehrenberg, A. S. C. 1975. Data Reduction: Analysing and Interpreting statistical Data. John Wiley and Sons, N. Y.

Energy Policy Project of the Ford Foundation 1974. Energy Consumption in Manufacturing. The Conference Board in Cooperation with the NSF, Ballinger Publishing Co., Cambridge, Massachussetts. 
Executive Office of the President, Energy Policy and planning 1977. President Carter's Energy Program.

Ferguson, C. E. and C. E. Maurice 1970. Economic Analysis. Irwin.

Fisher, G. H. 1971. Cost Considerations in Systems Analysis. American Elsevier Publishing Company, Inc., New York.

Freund, J. E. 1971. Mathematical Statistics. Prentice-Hall, New Jersey.

Gale, D. 1960. The theory of Linear Economic Models. Mc-Graw HiII, N. Y.

Goldberger, A. S. 1967. Functional Form and Utility: A Review of the Consumer Demand Theory. Social Systems Research Institute, University of wisconsin: Systems Formulation, Methodology and Workshop Paper 6703.

Horst, P. 1965. Factor Analysis of Data Matrices. Holt, Rinehart and Winston, Inc., New York.

Houthaker, H. S. and I. D. Taylor 1966. Consumer Demand in the United States, 1929-1970. Harvard University Press.

International Petroleum Annual, Published by the U.S. Bureau of Mines.

Johnston, J. 1972. Econometric Methods. McGraw-Hill, New York.

Kalymon, B. A. 1975. "Economic Incentives in OPEC O11 Pricing," Journal of Development Economics, 2, pp. 337-362, North Holland Publishing Co.

Kaufman, E. M. 1963. Statistical Decision and Related Techniques in OII and Gas Exploration. Prentice-Hall, New Jersey.

Lea, S. 1975. Higher Oil Prices: Worldwide Financial Implications. British-North American Committe.

Leach, G. 1973. "The Motor car and Natural Resources," OECD Working Paper No. 4.

Malinvaud, E. 1966. Statistical Methods of Econometrics. Rand McNaliy and Company, Chicago.

Mande1, J. 1964. The Statistical Analysis of Experimental data. John Wiley, New York.

Manne, A. S. 2975. 2What Happens When our Oi i and Gas Run out?" Harvard Business Review, July-August, pp. 123-37

Mansfield, E. 1970. Micro-Economics: Theory and Applications. W. W. Norton and Co. Inc., N. Y. 
Meyer, J. and E. Kuh 1957. "How Extraneous are Extraneous Estimates?" Rev. Economics and Statistics, Vol. 39, pp. $380-393$.

Morris, W. T. 1967. "On the Art of Modeling;" Management Science, Vol. 13, No. 12 .

Morrison, D. F. 1967. Multivariate Statistical Methods. MCGraw-Hill, New York.

OECD 1969. "Steel Demand Forecasting in OECD Countries," OECD, Paris.

OECD 1975. "Energy $R \& D$ Problems and Prospectives," OECD, Paris.

OECD Main Economic Indicators: Historical Statistics.

Plog, F. T. 1974. The Study of Prahistoric Change. Academic Press.

Robinson, C. 1975. "The Depietion of Energy Resources," Economics of Natural Resource Depietion. Edited by D. W. Pearce and J. Rose.

Rothkopf, M. H. and H. de Vries 1974. "Modelling Future Energy Supply," Energy: From Surplus to Scarcity. Edited by K. A. D. Inglis, Halsted Press.

Samuelson, R. A. 1973. Economics. MCGraw-Hili, N. Y.

Stone, J. R. N. 1954 . The Measurement of Consumers Expenditure and Behaviour in the Untted Kingdom, 1920-1938. Cambridge, London.

Shannon; R. E, 1975. Systems Simulation: The Art and Science, Prentice-Hail, Inc.

Thompson. W. O. and B. C. Foster 1973. "Proceedings of the Univeesity of Kentucky Conference on Regression with a Large Number of Predictor Variables".

Wheelwright, S. C. and S. Makridakis 1973. Forecasting Methods for Management. John Wiley and Sons, N. Y. 